UNIVERSIDADE DE SÃO PAULO

FACULDADE DE EDUCAÇÃO

PROGRAMA DE PÓS-GRADUAÇÃO EM EDUCAÇÃO

ÁREA DE CONCENTRAÇÃO: ESTADO, SOCIEDADE E EDUCAÇÃO

TAÍZA DA SILVA GAMA

LIMITES E POSSIBILIDADES DO EXERCÍCIO DO DIREITO À EDUCAÇÃO NAS PRISÕES DO ESTADO DO RIO DE JANEIRO: UM ESTUDO DE CASO NO COLÉGIO ESTADUAL JOSÉ LEWGOY

SÃO PAULO 
TAÍZA DA SILVA GAMA

\title{
LIMITES E POSSIBILIDADES DO EXERCÍCIO DO DIREITO À EDUCAÇÃO NAS PRISÕES DO ESTADO DO RIO DE JANEIRO: UM ESTUDO DE CASO NO COLÉGIO ESTADUAL JOSÉ LEWGOY
}

\author{
Tese apresentada ao Programa de Pós-graduação em \\ Educação da Universidade de São Paulo como pré-requisito \\ para a obtenção do título de Doutora em Educação. \\ Área de concentração: Estado, Sociedade e Educação \\ Orientador: Prof. Dr. Roberto da Silva. \\ VERSÃO CORRIGIDA
}


Autorizo a reprodução e divulgação total ou parcial deste trabalho, por qualquer meio convencional ou eletrônico, para fins de estudo e pesquisa, desde que citada a fonte.

Catalogação da Publicação

Ficha elaborada pelo Sistema de Geração Automática a partir de dados fornecidos pelo(a) autor(a) Bibliotecária da FE/USP: Nicolly Soares Leite - CRB-8/8204

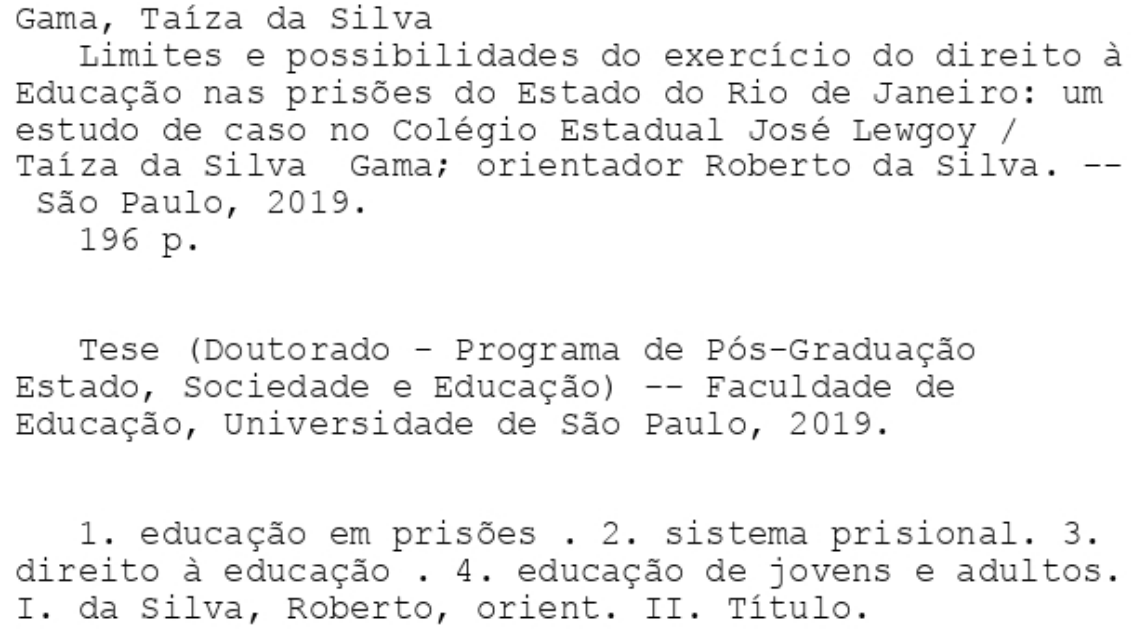


Nome: GAMA, Taíza da Silva

Título: Limites e possibilidades do exercício do direito à Educação nas prisões do Estado do Rio de Janeiro: um estudo de caso no Colégio Estadual José Lewgoy

Tese apresentada ao Programa de Pós-graduação em Educação da Universidade de São Paulo como pré-requisito para a obtenção do título de Doutora em Educação.

Área de concentração: Estado, Sociedade e Educação

Aprovada em: 27/11/2019

\section{BANCA EXAMINADORA}

Prof. Dr. Roberto da Silva - USP

Prof. Dr. Elionaldo Fernandes Julião - UFF

Prof $^{\circ}$ Dr. Hélio Roberto Braunstein - UFMS

Prof $^{a}$ Dra. Mariângela Graciano - UNIFESP

Prof $^{a}$ Dra. Maria Clara Di Pierro - USP

Prof $^{\mathrm{a}}$ Dra. Carolina Bessa Ferreira de Oliveira - UFSB

Prof $^{a}$ Dra. Ana Carolina Huguenin Pereira - UERJ

Prof $^{a}$ Dra. Gabriela Isabel Reyes Ormeno - UFPR

Prof $^{a}$ Dra. Mônica Guimarães Teixeira do Amaral - USP

Prof $^{a}$ Dr. Afrânio Mendes Catani - USP 
Aos meus pais. 


\section{AGRADECIMENTOS}

Acredito que nenhuma obra é individual. Nós somos um pouco de cada um que nos rodeia, além disso, as etapas de construção do pensamento são repletas de interseções que nos marcam, às vezes até o fim de nossas vidas. Nesta perspectiva, teço aqui diminutos agradecimentos aos que, sem eles, nada do que existe nesta tese seria possível.

Primeiramente, toda glória e honra a Deus, que tem estendido a sua mão sobre mim, dando-me benções, sendo o exemplo maior de amor que consigo conceber.

Aos meus pais, Sônia Maria da Silva Gama e Roberto Luiz de Mendonça Gama, que, desde os remotos tempos de minha vida, me permitiram alçar os voos necessários para concluir esta tese. A eles dedico este trabalho!

Ao meu irmão, Leandro da Silva Gama, pelo apoio e pelo incentivo durante toda essa jornada.

Aos meus avós, em especial, à Henny de Mendonça Gama (in memoriam), que me deixou o exemplo de como ser educadora e mulher.

Às professoras da família, minha tia Lais Célia e minhas primas Ludmila Gama e Pâmela Coelho por escolherem, junto comigo, uma das mais nobres profissões. Nossa luta é diária!

Agradeço a Domingos Leite Soutelo, por sempre confiar no meu potencial e acreditar em mim, inclusive, em algumas oportunidades, mais do que eu mesma. Obrigada pelo incentivo e pelo apoio!

Ao Programa de Pós-graduados em Educação da FEUSP e a todos os professores que muito contribuíram para este trabalho.

Ao meu orientador, Professor Dr Roberto da Silva, pela sua história de vida e por seu notório saber, que fez parte deste processo. Obrigada pelos anos de convivência!

Aos colegas de turma, em especial, à Aline Ângelo, pelo companheirismo durante todo o curso. Obrigada pela companhia no CRUSP e pelas nossas conversas, mesmo à distância! Sempre recebi de você uma palavra amiga e um incentivo para continuar em minha jornada. Agradeço a Deus por ter me dado o presente de ser sua amiga!

Aos professores Dr. Elionaldo Julião e Dra. Carolina Bessa, que aceitaram com carinho, a participar das bancas de qualificação e de defesa deste trabalho. Suas observações foram fundamentais para os encaminhamentos de toda a pesquisa.

Agradeço também, a todos os professores presentes na banca de defesa desta tese. Obrigada pelas contribuições de vocês!

Ao Laboratório de Serviço Social e Novos Projetos Societários na América Latina (LASSAL) e à professora e amiga Dra. Luci Faria Pinheiro. 
Aos amigos Sérgio Luis Alves, Leonardo Madeira, Raquel Miranda e Arthur Rodrigues, que, com todo o companheirismo, renovam a minha fé no amor e na amizade. Obrigada pelo incentivo e pelo apoio, principalmente nos momentos finais desta tese!

Agradeço a Alexandre Amaral e à Marina Carvalho que, pacientemente, me ajudaram com as traduções necessárias para esta pesquisa.

Não poderia deixar de agradecer aos meus ex-alunos do curso de Tecnologia em Segurança Pública e Social da Universidade Federal Fluminense, em especial aos alunos da turma 2014.2, que me fizeram desenvolver um olhar mais apurado sobre os profissionais de Segurança Pública do Estado do Rio de Janeiro, compreendendo a importância de seus papéis na sociedade, apesar de todas as dificuldades vivenciadas no cotidiano de suas profissões, que, muitas vezes, transcendem as teorias acadêmicas.

Por fim, agradeço aos professores do Colégio Estadual José Lewgoy que muito contribuíram para a realização deste trabalho; à Secretaria do Estado de Educação e a todos os homens e mulheres que se encontram privados de sua liberdade, em especial aos que participaram da pesquisa de campo que culminou nesta tese. Obrigada pelo que aprendi com vocês! 


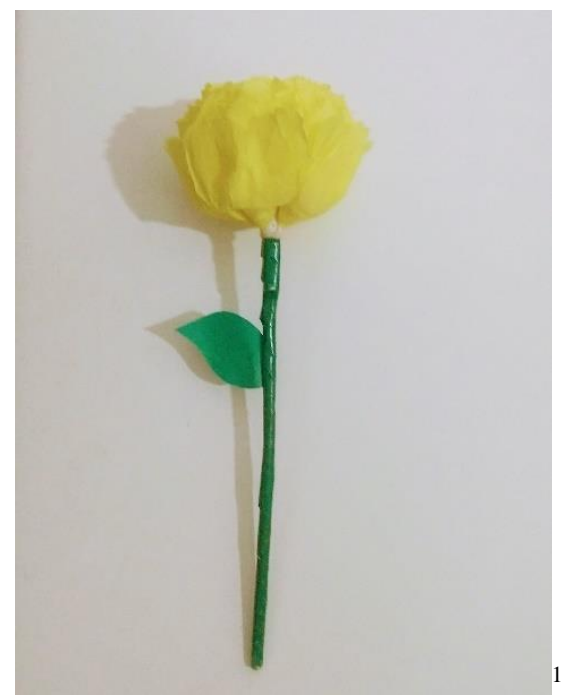

Ao mestre, a Flor

Adubar a terra com números e letras asas e poemas para colher lírios cravos e alfazemas

Agricultor o bom mestre sabe que espinhos e pétalas fazem parte da primavera porque ensinar é regar a semente sem afogar a flor

Sérgio Vaz (2011, p. 146)

${ }^{1}$ Flor de papel confeccionada por um aluno do Colégio Estadual José Lewgoy, localizado na Penitenciária Moniz Sodré/RJ. Fonte: Arquivo pessoal, setembro de 2019. 


\section{RESUMO}

GAMA, Taíza da Silva. Limites e possibilidades do exercício do direito à Educação nas prisões do Estado do Rio de Janeiro: um estudo de caso no Colégio Estadual José Lewgoy. 2019. 196 p. Tese (Doutorado) - Faculdade de Educação, Universidade de São Paulo, 2019.

A presente tese tem como objetivo investigar, a partir de um estudo de caso, a capacidade do Estado do Rio de Janeiro em promover, garantir e defender o direito à educação dos presos sob sua responsabilidade, tomando como marco referencial os princípios e as orientações emanadas das Diretrizes Nacionais para a Oferta da Educação em Estabelecimentos Penais (BRASIL, 2010), cujo propósito é a institucionalização da educação em prisões como parte constituinte da política educacional brasileira. Sua hipótese norteadora é a de que o Estado do Rio de Janeiro pode assegurar a efetivação do direito à educação nas prisões ainda que sejam necessários ajustes e adequações tanto na política criminal e penitenciária do Estado, quanto em suas unidades prisionais. Esta tese foi desenvolvida no período de 2015 a 2019 e se guia pelo viés de uma abordagem diagnóstica atrelada aos campos da Educação e do Direito, compreendendo, necessariamente, a revisão da bibliografia especializada, especialmente no que se refere à história e à avaliação da educação em prisões no Estado do Rio de Janeiro após a promulgação das Diretrizes, bem como a pesquisa documental, tendo em vista os novos marcos regulatórios para a oferta da educação em prisões. A base empírica da pesquisa foi constituída por meio da seleção de uma unidade prisional do Estado do Rio de Janeiro, o Colégio Estadual José Lewgoy, localizado no Complexo Penitenciário de Gericinó, no bairro de Bangu, onde foram realizadas entrevistas com alunos e professores. Como resultado da pesquisa, foram identificadas novas possibilidades de atuação nas prisões no sentido de estabelecer condições que garantam o acesso à educação para todos.

Palavras-chave: educação em prisões - sistema prisional - direito à educação - educação de jovens e adultos 


\section{RESUMEN}

GAMA, Taíza da Silva. Límites y Posibilidades del Ejercicio del Derecho a la Educación en las prisiones del Estado de Río de Janeiro: un estudio de caso en el Colegio Estadual José Lewgoy. 2019. p.196. Tesis (Doctorado) - Faculdade de Educação, Universidade de São Paulo, 2019.

La presente tesis tiene como objetivo investigar, partiendo de un estudio de caso, la efectiva capacidad de las prisiones del estado de Río de Janeiro en promover, garantizar y defender el derecho a la educación de los detenidos bajo su responsabilidad, teniendo como marco de referencia los principios y las orientaciones emanados de Diretrizes Nacionais para a Oferta da Educação em Estabelecimentos Penais (Directrices Nacionales para la oferta de la Educación en Establecimientos Penales) (BRASIL, 2010), cuyo propósito es la institucionalización de la educación en prisiones como parte constitutiva de la política educativa brasileña. La hipótesis orientadora de esta investigación es la de que el estado de Río de Janeiro pueda asegurar la efectivación del derecho a la educación en las prisiones aunque sean necesarios ajustes y adecuaciones tanto en su política criminal y penitenciaria como en sus unidades prisionales. Esta tesis, desarrollada en el período de 2015 a 2019, se orienta por el enfoque diagnóstico entrelazado a los campos de la Educación y del Derecho incluyendo necesariamente, la revisión de la bibliografia especializada, en lo que se refiere a la historia y a la evaluación de la educación en las prisiones en el Estado de Río de Janeiro tras la promulgación de las Directrizes y la investigación documental, considerando los nuevos marcos regulatorios para la oferta de la educación en prisiones. La base empírica de la investigación fue constituída por medio de la selección de una unidad prisional del Estado de Río de Janeiro, el Colégio Estadual José Lewgoy, ubicada en el Complejo Penitenciario de Gericinó, en el barrio de Bangu, donde fueron realizadas entrevistas con estudiantes y profesores. Como resultado de la investigación, fueron identificadas nuevas posibilidades de actuación en las prisiones en el sentido de establecer condiciones que garantizan el acceso a la educación para todos.

Palabras clave: educación en prisiones - sistema penitenciario - derecho a la educación - educación de jóvenes y adultos 


\begin{abstract}
GAMA, Taíza da Silva. Limits and Possibilities of the Exercise of the Right to Education in Rio de Janeiro State Prisons: a case study at José Lewgoy State School. 2019. 196 p. Doctoral Thesis - Faculdade de Educação, Universidade de São Paulo, 2019.

This thesis aims to investigate, from a case study, the ability of prisons in the state of Rio de Janeiro to promote, guarantee and defend the right to education of prisoners under their responsibility, taking as reference the principles and guidelines emanating from the Diretrizes Nacionais para a Oferta da Educação em Estabelecimentos Penais (BRAZIL, 2010), whose purpose is the institutionalization of education in prisons as a constituent part of the Brazilian educational policy. Its guiding hypothesis is that the state of Rio de Janeiro can ensure the realization of the right to education in prisons even if adjustments are required both in the state's criminal and penitentiary policy and in its prison units. This thesis was developed in the period from 2015 to 2019 and is guided by the bias of a diagnostic approach linked to the fields of Education and Law, necessarily including the revision of the specialized literature, especially with regard to the history and evaluation of education in prisons in the state of Rio de Janeiro after the promulgation of the National Guidelines, as well as documentary research in view of new regulatory frameworks for the provision of prison education. The empirical basis of the research was constituted by the selection of a prison unit in the state of Rio de Janeiro, the José Lewgoy State College, located in the Gericinó Penitentiary Complex, in the Bangu neighborhood, where interviews were held with students and teachers. As a result of the research, new possibilities for working in prisons were identified to establish conditions that guarantee access to education for all.
\end{abstract}

Keywords: prison education - prison system - right to education - youth and adult education 


\section{LISTA DE ILUSTRAÇÕES}

Figura 1 - Planta do Panóptico …………………………............................................. 30

Figura 2 - Planta da Casa de Correção da Corte (1834) …………………………………...... 35

Figura 3 - Extrato de Termo do Convênio nº 17/2017 firmado entre a SEAP e a SEEDUC 81

Figura 4 - Colégio Estadual José Lewgoy ........................................................................ 97

Figura 5 - Distância entre o Colégio Estadual José Lewgoy e o prédio onde ficam a sala administrativa e o refeitório dos funcionários 


\section{LISTA DE TABELAS}

Tabela 1 - Capacidade do sistema prisional e déficit de vagas por UF (2016)

Tabela 2 - Pessoas privadas de liberdade envolvidas em atividades educacionais por UF (2016)

Tabela 3 - Quantidade de presos no sistema prisional do Estado do Rio de Janeiro (2018)

Tabela 4 - Quantidade de presos em atividade escolar no sistema prisional do estado do Rio de Janeiro (2018)

Tabela 5 - Unidades escolares prisionais do Estado do Rio de Janeiro (2019) 49

Tabela 6 - Escolarização dos presos no Estado do Rio de Janeiro (2018) 79

Tabela 7 - Gratificação Especial por função (2018) 82

Tabela 8 - Escolaridade dos presos da Penitenciária Moniz Sodré (2018) 95

Tabela 9 - Quantitativo de alunos matriculados por unidade escolar prisional (2019) ....... 96

Tabela 10 - Matriz curricular para os anos iniciais do Ensino Fundamental nas Unidades Escolares Prisionais (2018) 104

Tabela 11 - Matriz curricular para os anos finais do Ensino Fundamental nas Unidades Escolares Prisionais (2018) 104

Tabela 12 - Matriz curricular do Ensino Médio nas Unidades Escolares Prisionais (2018) 105

Tabela 13 - Matriz curricular semipresencial para os anos finais do Ensino Fundamental nas Unidades Escolares Prisionais (2018) 105

Tabela 14 - Matriz curricular semipresencial do Ensino Médio nas Unidades Escolares Prisionais (2018) 106

Tabela 15 - Perfil dos alunos entrevistados 


\section{LISTA DE ABREVIATURAS E SIGLAS}

AEPLIERJ

ALERJ

CABA

CEB

CECIERJ

CEDERJ

CEFET

$\mathrm{CNE}$

$\mathrm{CNJ}$

CNPCP

COESP

CONFINTEA

CUD

DEGASE

DESIPE

DIESP

DOERJ

EJA

ENEM

E-SIC-RJ

FUNDEB

GESEC

IBGE

LDB

MEC

MP

OEA
Associação dos Educadores dos Privados de Liberdade do Estado do Rio de Janeiro

Assembleia Legislativa do Estado do Rio de Janeiro

Ciudad Autónoma de Buenos Aires

Câmara de Educação Básica

Centro de Ciências e Educação Superior a Distância do Estado do Rio do Janeiro

Centro de Educação Superior a Distância do Estado do Rio de Janeiro

Centro Federal de Educação Tecnológica

Conselho Nacional de Educação

Conselho Nacional de Justiça

Conselho Nacional de Política Criminal e Penitenciária

Coordenadoria Especial de Unidades Escolares Prisionais e Socioeducativas

Conferência Internacional sobre Educação de Adultos

Centro Universitario Devoto

Departamento Geral de Ações Socioeducativas

Departamento de Administração Penitenciária

Diretoria Especial das Escolas Socioeducativas e Prisionais

Diário Oficial do Estado do Rio de Janeiro

Educação de Jovens e Adultos

Exame Nacional do Ensino Médio

Sistema Eletrônico de Informação ao Cidadão

Fundo de Manutenção e Desenvolvimento da Educação Básica e de Valorização dos Profissionais da Educação

Grupo de estudio sobre Educación en Cárceles

Instituto Brasileiro de Geografia e Estatística

Lei de Diretrizes e Bases da Educação Nacional

Ministério da Educação

Ministério Público

Organização dos Estados Americanos 
ONU

PBA

PEE

PEEP

PEESP

PNAD

PNDH

PNE

POLINTER

PPP

SEAP

SECADI

SECTDS

SEEDUC

SENAC

SENAI

SIPEN

SUSIPE

UAB

UENF

UEPB

UERJ

UFF

UFRJ

UFRRJ

UNESCO

UNIRIO

USP
Organização das Nações Unidas

Programa Brasil Alfabetizado

Plano Estadual de Educação

Plano Estadual de Educação em Prisões

Plano Estratégico de Educação no âmbito do Sistema Prisional

Pesquisa Nacional por Amostra de Domicílio

Programa Nacional de Direitos Humanos

Plano Nacional de Educação

Delegacia de Polícia Interestadual

Projeto Político Pedagógico

Secretaria de Estado de Administração Penitenciária

Secretaria de Educação Continuada, Alfabetização, Diversidade e Inclusão

Secretaria de Estado de Ciência, Tecnologia e Desenvolvimento Social

Secretaria de Estado de Educação

Serviço Nacional de Aprendizagem Comercial

Serviço Nacional de Aprendizagem Industrial

Sistema de Identificação Penitenciária

Superintendência do Sistema Penitenciário

Universidade Aberta do Brasil

Universidade Estadual do Norte Fluminense

Universidade Estadual da Paraíba

Universidade do Estado do Rio de Janeiro

Universidade Federal Fluminense

Universidade Federal do Rio de Janeiro

Universidade Federal Rural do Rio de Janeiro

Organização das Nações Unidas para a Educação, a Ciência e a Cultura Universidade Federal do Estado do Rio de Janeiro

Universidade de São Paulo 


\section{LISTA DE GRÁFICOS}

Gráfico 1 - Evolução da taxa de aprisionamento no Brasil entre 2000 e 2016 ................. 38

Gráfico 2 - Escolaridade das pessoas privadas de liberdade no Brasil ............................ 40 


\section{SUMÁRIO}

INTRODUÇÃO .................................................................................................................. 18

Parte I - As memórias do passado e as bases do presente.................................................... 19

Parte II - Os primeiros passos da pesquisa: objetivos, hipótese, justificativas e metodologia .. 21

\section{A HISTÓRIA DA POLÍTICA DE RESTRIÇÃO E PRIVAÇÃO DE LIBERDADE NA SOCIEDADE CONTEMPORÂNEA E A EDUCAÇÃO NAS PRISÕES .................................. 26}

1.1 Bases teóricas fundamentais para o estudo das prisões …………………………………. 28

$1.2 \mathrm{O}$ passado e o presente: concepções históricas sobre as prisões no Brasil ........................... 33

1.3- Breve histórico sobre a educação no Sistema Prisional do Estado do Rio de Janeiro ....... 43

\section{A GARANTIA DO DIREITO À EDUCAÇÃO NAS PRISÕES DO BRASIL E DO ESTADO DO RIO DE JANEIRO ................................................................................................53}

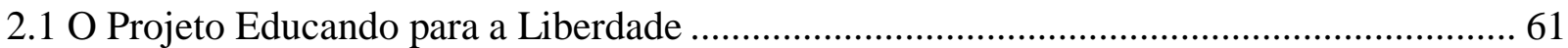

2.2 As Diretrizes Nacionais para a Oferta de Educação nos Estabelecimentos Penais .............. 67

2.3 As Diretrizes Nacionais para a oferta de educação para jovens e adultos em situação de

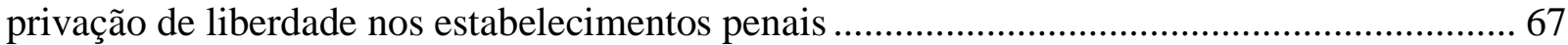

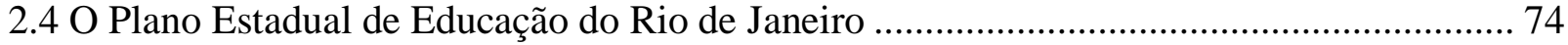

2.5 O Plano Estadual de Educação em Prisões do Rio de Janeiro ............................................... 76

\section{OS LIMITES E AS NOVAS POSSIBILIDADES ENTRE A EDUCAÇÃO E AS PRISÕES}

3.1 As dificuldades encontradas durante a pesquisa e suas adaptações...................................... 88

3.2 O espaço escolar: o Colégio Estadual José Lewgoy e o seu Projeto Político Pedagógico .. 93

3.3 A experiência docente: diálogos com os professores do Colégio Estadual José Lewgoy . 110

3.4 O aluno do Colégio Estadual José Lewgoy …………………………………………...... 116

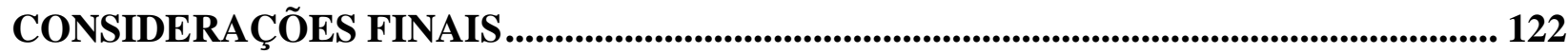

REFERÊNCIAS BIBLIOGRÁFICAS _....................................................................127

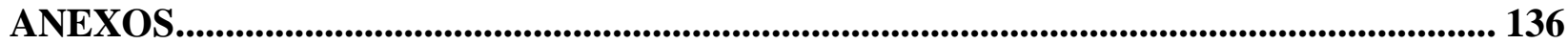

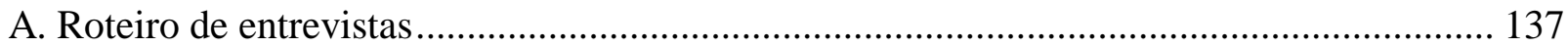

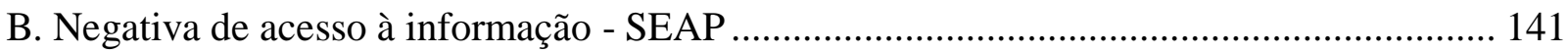

C. Autorização para realização da pesquisa.......................................................................... 142

D. Projeto político pedagógico do Colégio Estadual José Lewgoy .......................................... 144 


\section{INTRODUÇÃO}

Nenhuma "ordem" opressora suportaria que os oprimidos todos passassem a dizer: "Por quê?” (FREIRE, 2017, p. 106)

Diante da constante crise do sistema prisional brasileiro, onde milhares de pessoas estão sujeitas a situações degradantes e desumanas, vê-se claramente a ineficácia do aprisionamento como a principal resposta do Estado e da sociedade à criminalidade, à delinquência e à violência. Os inúmeros sinais de crise das prisões são apresentados a todo o momento tendo em vista a crescente aglomeração de indivíduos encarcerados, atrelada a disfunção da justiça criminal e dos mecanismos de controle da criminalização.

Segundo o Levantamento Nacional de Informações Penitenciárias do Departamento Penitenciário Nacional ${ }^{2}$, o Brasil possui o terceiro maior sistema prisional do mundo, com 726.712 pessoas privadas de liberdade, incluindo os condenados de todos os regimes (aberto, semiaberto e fechado) e os presos provisórios que aguardam decisão judicial. O sistema prisional brasileiro tem capacidade para 368.049 pessoas, portanto o déficit nacional é de 358.663 vagas. Deste montante, 50.219 estão encarcerados nos 49 presídios do Estado do Rio de Janeiro, cuja capacidade é de 28.443 detentos. Assim, o déficit estadual é de 21.776 vagas.

O levantamento do DEPEN (2017) também destaca que o Rio de Janeiro é o quarto estado que mais encarcera no Brasil, ficando abaixo somente dos estados de São Paulo, com 240.061 pessoas privadas de liberdade, de Minas Gerais, com 68.354, e do Paraná, com 51.700.

Haja vista este cenário caótico de indicadores com aumentos constantes, estudos de Araújo (2009), Aguirre (2009) e Bretas et al. (2009), além de considerarem as prisões cariocas como locais de reprodução da violência, chamam a atenção para o fato de, historicamente, as políticas públicas voltadas para a população prisional não garantirem os direitos dos indivíduos encarcerados e muito menos os prepararem para o retorno à sociedade, se distanciando notoriamente daquilo que é necessário para fazer cumprir sua função de reintegração social ${ }^{3}$.

\footnotetext{
${ }^{2}$ Disponível em: < http://depen.gov.br/DEPEN/depen/sisdepen/infopen/relatorios-sinteticos/relatorio_2016_2211.pdf $>$. Acesso em 09 out. 2019.

${ }^{3}$ Utilizaremos ao longo desta tese o termo "reintegração social" pelo fato de ter o conceito que mais se aproxima do nosso pensamento entre todas as ideologias "res" associadas ao universo prisional (ressocialização, reeducação, reabilitação, etc.). Atribuímos o termo ao núcleo que compreende como estratégias e práticas de descarcerização, a criação de condições culturais e políticas que façam com que a sociedade se liberte da necessidade da prisão. Para uma análise mais aprofundada sobre esta temática, ver Baratta (1990) e Braga (2012).
} 
Em 2016, conforme apresentado pelo DEPEN (BRASIL, INFOPEN, 2017), apenas 95.919 pessoas estavam envolvida em atividades laborais, internas e externas aos estabelecimentos penais, o que representa $15 \%$ da população prisional. A assistência educacional, prevista na Lei de Execução Penal (LEP - Lei no 7.210, de 11 de julho de 1984), compreende a instrução escolar e a formação profissional para todas as pessoas privadas de liberdade, entretanto, somente $10 \%$ da população prisional no Brasil está envolvida em atividades de ensino. Destas 61.642 pessoas, 3.142 se encontram no Estado do Rio de Janeiro (RIO DE JANEIRO, PEEP, 2018) ${ }^{4}$.

Com isso surgem alguns questionamentos: Quais são as ações que têm sido tomadas pelo Estado do Rio de Janeiro no sentido de assegurar o direito à educação de sua população prisional? Como a educação escolar está configurada nos presídios cariocas? Qual é o papel que a educação exerce no processo de reintegração social, considerando a realidade das prisões do estado do Rio de Janeiro?

Introduzo o início desta tese tomando os dados apresentados acima como marcos iniciais dos questionamentos que me levaram a escolha da temática aqui desenvolvida. Este estudo é oriundo de um contexto acadêmico e pessoal pautado na busca por respostas acerca das prisões do Estado do Rio de Janeiro. Os caminhos que percorri, minha experiência de vida e meus desdobramentos acadêmicos foram fatores fundamentais em todo o processo de investigação que seguirá nas próximas linhas.

\section{Parte I - As memórias do passado e as bases do presente}

A principal motivação que deu origem a esta pesquisa se deve ao interesse pelo estudo das prisões manifestado durante a minha formação acadêmica em Direito onde, entre os anos de 2008 a 2010, me submeti ao estágio de prática jurídica na extinta carceragem da Delegacia de Polícia Interestadual (Polinter), localizada no Município de São Gonçalo, no Estado do Rio de Janeiro. Neste período, integrei o Núcleo de Estudos e Pesquisas de Trabalho, Política e Movimentos Sociais, da Universidade Federal Fluminense (UFF), onde desenvolvi uma pesquisa através de observações empíricas, análise documental, entrevistas e acompanhamento das práticas sociais na carceragem da Polinter, cujos esforços culminaram em minha monografia de conclusão de curso.

\footnotetext{
${ }^{4}$ Dados fornecidos pela Secretaria de Estado de Educação através do Plano Estadual de Educação em Prisões.
} 
Nos anos finais da graduação em Direito iniciei o curso de Licenciatura em Letras na Universidade do Estado do Rio de Janeiro (UERJ), instituição que me abriu as portas para a pesquisa voltada à educação nas prisões. Foi na Faculdade de Formação de Professores da UERJ onde pude perceber o início de uma verdadeira transformação nas minhas concepções acadêmicas e pessoais que resultaram na construção de uma visão crítico-reflexiva muito mais ampliada, me tornando uma professora pesquisadora.

Em 2013 a orientação do professor Dr. Jorge Antônio da Silva Rangel na UERJ deu origem ao trabalho monográfico do curso de Licenciatura em Letras intitulado "Histórias Contadas, Histórias Inventadas: os limites e desafios das oficinas de leitura no cotidiano prisional do Estado do Rio de Janeiro", que trouxe à tona diversas reflexões a respeito da temática da educação nas prisões e contribuiu para a escolha dos caminhos pelos quais delimitei o foco dos estudos de doutorado.

Nesse ínterim, ingressei no curso de mestrado em Política Social na Universidade Federal Fluminense, onde concluí em 2014, um trabalho dissertativo sobre religião e sistema prisional no Estado do Rio de Janeiro, com orientação da professora Dra. Luci Faria Pinheiro, que gerou a publicação em 2017, do livro "Religião e sistema prisional: um estudo sobre a assistência religiosa pentecostal no processo de reintegração da população carcerária do Estado do Rio de Janeiro”.

A presente tese intitulada "Limites e possibilidades do exercício do direito à educação nas prisões do Estado do Rio de Janeiro" teve início em julho de 2015, com o ingresso no programa de pós-graduação da Faculdade de Educação da Universidade de São Paulo, na área de concentração "Estado, Sociedade e Educação".

As conversas e debates com pesquisadores da área ao longo de todo o curso de doutorado possibilitaram um maior esclarecimento sobre as ideias teórico-metodológicas contidas nesta tese. Neste sentido, destacam-se as reuniões do Grupo de Trabalho sobre Educação no Sistema Socioeducativo, da UFF, coordenado pelo Prof $^{\circ}$ Dr. Elionaldo Julião, e as conversas, mesmo à distância, com os colegas do Grupo de Estudos e Pesquisas sobre Educação em Regimes de Privação da Liberdade - GEPÊPrivação, da USP, coordenado pelo Prof ${ }^{\circ}$ Dr. Roberto da Silva.

Em março de 2017 realizei uma visita técnica ao Grupo de estudio sobre Educación en Cárceles-GESEC ${ }^{5}$, localizado na cidade de La Plata, em Buenos Aires/Argentina. O grupo tem como principal objetivo a promoção do exercício do direito à Educação às pessoas privadas de

\footnotetext{
${ }^{5}$ Maiores informações em: www.gesec.com.ar
} 
liberdade, e se destaca por sua característica interdisciplinar e pelo trabalho voltado para a perspectiva dos Direitos Humanos. Também foi possível visitar o Centro Universitario Devoto (CUD), localizado no Complejo Penitenciario Federal de CABA, onde pude observar a experiência da Argentina com a educação universitária em prisões e traçar um paralelo com a realidade prisional do Estado do Rio de Janeiro.

\section{Parte II - Os primeiros passos da pesquisa: objetivos, hipótese, justificativas e metodologia}

O objetivo da pesquisa aqui desenvolvida consiste em investigar a efetiva capacidade do sistema penitenciário do Estado do Rio de Janeiro em promover, garantir e defender o direito à educação das pessoas privadas de liberdade sob sua responsabilidade, tendo como marco referencial os princípios e orientações emanadas das Diretrizes Nacionais para a Oferta da Educação em Estabelecimentos Penais (BRASIL, 2010), cujo propósito é a institucionalização da educação em prisões como parte constituinte da política educacional brasileira.

Segundo Julião (2013), o Brasil já ultrapassou a etapa que discute o direito à educação nas prisões, sendo necessário agora, analisar as suas práticas e experiências com o intuito de avaliar seus resultados através de programas, propostas e políticas. Assim, em linhas gerais, o estudo realizado ao longo desta pesquisa de doutorado define como hipótese inicial de investigação a capacidade do sistema penitenciário do Estado do Rio de Janeiro de assegurar a efetivação do direito à educação de sua população prisional ainda que sejam necessários ajustes e adequações tanto na política criminal e penitenciária do Estado, quanto em suas unidades prisionais.

No entanto, primeiramente é necessário compreender que a educação nas prisões não deve tomar para si a tarefa de reintegração social proposta pelo sistema prisional, mas sim contribuir para a construção de sujeitos autônomos, capazes de identificar novas alternativas para a vida fora da prisão.

A coleta de dados foi realizada no período de 2015 a 2019 e se deu de forma qualitativa, com o objetivo de proporcionar uma análise diagnóstica mais aprofundada sobre a temática. Neste sentido, apesar de se tratar de uma pesquisa diagnóstica ao buscar investigar a efetiva capacidade do Estado do Rio de Janeiro em cumprir a lei, esta tese se guia pelo viés de uma abordagem qualitativa atrelada aos campos da Educação e do Direito, preocupando-se com aspectos da realidade dos sujeitos e com a compreensão da dinâmica das relações sociais. Tomando como base 
os estudos de Bogdan \& Biklen (1994), o método de condução da investigação aqui desenvolvida reflete uma espécie de diálogo entre o investigador e os respectivos sujeitos, resultando num processo contínuo de questionamentos.

$\mathrm{O}$ acesso restrito aos documentos e a burocracia imputada pelo Estado do Rio de Janeiro aos pesquisadores nos fizeram percorrer caminhos diversos dos que foram projetados no início do curso de doutorado em Educação. Esta pesquisa esbarrou em inúmeros entraves no acesso às informações que, na teoria, deveriam ser públicas. ${ }^{6}$ Por este motivo, decidimos eleger como objeto de estudo a unidade escolar prisional pela qual conseguimos maior número de dados na fase da pesquisa documental: o Colégio Estadual José Lewgoy, localizado no Complexo Penitenciário de Gericinó, no bairro de Bangu.

Neste sentido, optamos pela metodologia qualitativa por meio de um estudo de caso. Segundo Vieira (2014), em Educação, os trabalhos com estudo de caso têm início nas décadas 60 e 70 através da análise descritiva de uma unidade: uma escola, um professor, uma sala de aula. André (2013) aponta o estudo de caso como método possível de traduzir uma série de questões, em pontos críticos ou em hipóteses provisórias.

Stake (1983) considera que, devido à complexidade do mundo social, é necessário que o pesquisador estude casos para compreender determinado fenômeno em profundidade. Por este motivo, esta metodologia é utilizada em diferentes áreas como Medicina, Direito e Humanidades. Na Educação, por sua vez, o estudo de caso é desenvolvido a partir de múltiplas áreas do conhecimento.

Segundo Stake (1983), o fator mais importante em um estudo de caso é privilegiar a compreensão do caso ao invés de generalizar para além dele. O autor se preocupa também, com a interpretação dos resultados pelos pesquisadores.

A subjetividade precisa ser reconsiderada. Penso que a subjetividade do observador de campo pode ser controlada, mas não eliminada. Controlada e usada, entretanto, de um modo vigoroso a fim de fazer com que as conclusões da pesquisa sejam mais relevantes e úteis (STAKE, 1983, p. 06).

Tomando como base a importância de tais cuidados apontados por Stake (1983), realizamos nossa pesquisa levando em consideração a singularidade da unidade social escolhida, entretanto, por considerar, assim como Greenwood (1963, p. 331), que uma "unidade de observação pode ser

\footnotetext{
${ }^{6}$ Merecem destaque os pedidos de informação realizados através do Sistema Eletrônico de Informação ao Cidadão (e-SIC-RJ) que foram negados ou não respondidos. Trataremos sobre este assunto no terceiro capítulo da tese.
} 
representativa de qualquer nível da realidade social", os resultados deste método de pesquisa foram alcançados através de um exame intensivo dos dados obtidos por meio de entrevistas semiestruturadas, tratando a unidade social investigada como totalidade, mas também a considerando como parte de uma questão ampla e possível de ser verificada em outras oportunidades.

Percebemos com isso, que as experiências vividas pelos sujeitos não podem ser deslocadas do espaço que os acompanham. Logo, procuramos investigar o conjunto das relações objetivas entre os agentes envolvidos no mesmo espaço social, construindo assim, um conjunto de agentes que se relacionam no mesmo campo e compartilham das mesmas possibilidades.

Também foram utilizadas como estruturas metodológicas desta pesquisa, a revisão bibliográfica dos principais trabalhos da literatura que abordam a temática da educação em prisões e o levantamento de dados de fontes primárias, secundárias e terciárias, com o objetivo de delinear caminhos ou contribuições teóricas que serviram de base para elucidações das questões propostas.

As fontes primárias para a coleta de dados são a Secretaria do Estado de Educação (SEEDUC-RJ) e a Secretaria do Estado de Administração Penitenciária (SEAP). As fontes secundárias são constituídas pelo Sistema de Informações Penitenciárias (INFOPEN), vinculado ao Departamento Penitenciário Nacional (DEPEN); e o Conselho Nacional de Justiça, por meio de seus relatórios periódicos - estes dois últimos instrumentos oficiais de coleta e organização de dados do sistema penitenciário brasileiro.

Os marcos legais, representados pelas normativas nacionais e internacionais, servem de parâmetros para análise de marcos operacionais empreendidos no sistema prisional em estudo. Assim, tomamos como marco inicial dessa pesquisa, a Resolução n ${ }^{\circ}$ 3, de 11 de março de 2009, do Conselho de Política Criminal e Penitenciária (CNPCP), que dispõe sobre as Diretrizes Nacionais para a oferta de educação nos estabelecimentos penais ${ }^{7}$.

Como fontes terciárias, usamos artigos, livros, teses e dissertações de caráter analítico e interpretativo da realidade do sistema prisional produzidas por uma variedade de autores críticos que serão capazes de aportar a este estudo o estado da arte em relação ao objeto da pesquisa.

O material resultante da pesquisa bibliográfica e documental foi analisado a partir da pertinência quanto às categorias enunciadas nos três eixos do Projeto Educando para a Liberdade

7 Disponível em: <http://portal.mec.gov.br/index.php?option=com_docman\&view=download\&alias=10028resolucao-3-2009-secadi\&category_slug=fevereiro-2012-pdf\&Itemid=30192>. Acesso em: 29/05/2019 
(UNESCO, 2006), documento inicial que deu origem à regulamentação da educação em prisões no Brasil. O primeiro eixo, "Gestão, articulação e mobilização", tem o objetivo de propor estímulos e subsídios para a atuação da União, dos estados e da sociedade civil, no que diz respeito à formulação, execução e monitoramento de políticas públicas para a educação nas prisões. Já o segundo eixo, "Formação e valorização dos profissionais envolvidos na oferta", pretende contribuir para a qualidade da formação e para as boas condições de trabalho de gestores, educadores, agentes penitenciários e operadores da execução penal. O terceiro eixo, por sua vez, compreende os "aspectos pedagógicos", e tem o objetivo de garantir a qualidade da oferta da educação nas prisões, com base nos fundamentos conceituais e legais da educação de jovens e adultos, bem como os paradigmas da educação popular, calcada nos princípios da autonomia e da emancipação dos sujeitos do processo educativo. ${ }^{8}$

O resultado da pesquisa documental foi analisado segundo os compromissos ratificados pelo Estado brasileiro quando da adesão aos tratados e convenções internacionais sobre o tratamento dado às pessoas privadas de liberdade. Destacam-se entre os instrumentos internacionais, o Pacto Internacional dos Direitos Civis e Políticos da Organização das Nações Unidas - $\mathrm{ONU}^{9}$, a Convenção Americana sobre os Direitos Humanos da Organização dos Estados Americanos - OEA e a Convenção contra a tortura e outros tratamentos ou penas cruéis, desumanos ou degradantes - ONU. ${ }^{10}$

Desta forma, esta tese foi organizada em três capítulos. O primeiro, intitulado "A política de restrição e privação de liberdade na sociedade contemporânea e a educação nas prisões", se estruturou com o objetivo de apresentar uma reflexão com base nos principais estudos que tratam acerca da política de restrição e privação de liberdade na sociedade contemporânea e sobre a educação no sistema prisional brasileiro, lançando assim, as bases teóricas para o desenvolvimento do conteúdo que será discutido ao longo de toda a tese. Também foram analisados os aspectos históricos da Educação no sistema prisional do Estado do Rio de Janeiro, levando em consideração a escassa bibliografia sobre esta temática.

\footnotetext{
${ }^{8}$ UNESCO, 2006.

${ }^{9}$ O Pacto Internacional dos Direitos Civis e Políticos - ONU, de 1966, proíbe penas e tratamentos cruéis e garante aos presos o tratamento com dignidade e as regras de separação.

${ }^{10}$ A Convenção Americana sobre os Direitos Humanos - OEA e a Convenção contra a tortura e outros tratamentos ou penas cruéis, desumanos ou degradantes - ONU resguardam o direito à integridade pessoal, além da individualização da pena e da proibição de tratamentos cruéis.
} 
No segundo capítulo foram identificadas as normativas internacionais, nacionais e estaduais sobre o direito à educação no Brasil e no Estado do Rio de Janeiro. Desta forma, analisamos as Diretrizes Nacionais para a Oferta da Educação em Estabelecimentos Penais (BRASIL, 2010) e sua relação com os compromissos ratificados pelo Estado brasileiro quando da adesão a tratados e convenções internacionais sobre o tratamento dado às pessoas privadas de liberdade. Foi feita uma investigação de forma aprofundada, sobre o processo de implantação das diretrizes nacionais no contexto prisional do Estado do Rio de Janeiro, considerando as categorias enunciadas nos três eixos do Projeto Educando para a Liberdade (UNESCO, 2006).

Com base nos subsídios teóricos dos capítulos anteriores, no terceiro capítulo foram analisados, através de pesquisa de campo, os marcos operacionais para o exercício do direito à Educação por parte da população prisional do Estado do Rio de Janeiro, identificando novas possibilidades de atuação Secretaria de Estado de Educação (SEEDUC) no sentido de estabelecer condições que garantam o acesso à educação para todos.

Nas considerações finais desta tese, foram apresentados os resultados da pesquisa através de elementos que buscam contribuir para a efetiva aplicabilidade na proposta político-pedagógica de educação nas prisões do Estado do Rio de Janeiro, das Diretrizes Nacionais para a Oferta de Educação nos estabelecimentos penais.

Reconhecemos esta pesquisa como uma construção social inacabada, sendo sua linha de interpretação considerada apenas como uma possibilidade entre tantas outras possíveis, no entanto, servindo como um ponto de partida para que futuras análises nos ofereçam novos olhares. 


\section{A HISTÓRIA DA POLÍTICA DE RESTRIÇÃO E PRIVAÇÃO DE LIBERDADE NA SOCIEDADE CONTEMPORÂNEA E A EDUCAÇÃO NAS PRISÕES}

A prisão é um debate permanente. Durante muitos anos serviu aos políticos como exemplo para exibir a adesão aos princípios liberais, entretanto, tempos depois, deixou de ser considerada como uma boa saída para os investimentos públicos, sendo relegada ao abandono e ao desprezo. Mas, qual é o seu verdadeiro sentido? O que colocar em seu lugar?

O crescimento desenfreado da violência e, consequentemente, da superlotação no sistema prisional são fatores preocupantes, mas não recentes. A sensação é a de que estamos em uma constante reforma penal que jamais será concluída. Do passado da prisão emanam muitas experiências adormecidas e retomá-las denota entender melhor uma parte significativa dos sistemas normativos da sociedade.

Elas trazem em sua história ao longo dos tempos, abuso, maus tratos, tortura, aflição, extermínio e também houve avanços técnicos com a intenção de ressocializar, trabalhos educativos e outros. Todavia neste início de milênio continua o lamento de que a prisão é permanente espetáculo deprimente que atinge além da pessoa do delinquente; orfana filhos de pai vivo; enviúva a esposa de marido combalido; prejudica o credor do preso tomado insolvente; desadapta o encarcerado à sociedade; suscita vários conflitos sexuais; onera o Estado; amontoa seres vivos em jaulas sujas, imundas, onde vegetam em terrível promiscuidade (...). Contudo, no conjunto mundial, sobretudo nos países de terceiro mundo, o panorama geral é ruim por isso se conclui que qualquer estabelecimento penitenciário de bom nível representa apenas uma ilha de graça, num mar de desgraças. (OLIVEIRA, E. 2002, p.60)

Este capítulo visa apresentar uma reflexão com base nos principais estudos que tratam acerca da história da política de restrição e privação de liberdade na sociedade contemporânea e sobre a educação no sistema prisional brasileiro e carioca, o que significa voltar o olhar para diversas trajetórias políticas e distintos padrões econômicos e sociais que foram constituídos ao longo do tempo.

Compreender a origem das prisões e o seu desdobramento na sociedade nos dará alicerces para construir uma visão mais crítica sobre a educação no sistema prisional - principal objeto deste estudo. Por este motivo, optamos primeiramente por analisar as principais pesquisas acadêmicas sobre as origens das prisões no Brasil lançando assim, as bases teóricas para o desenvolvimento do conteúdo que será discutido ao longo de toda a tese.

Segundo Aguirre (2009), a historiografia sobre a origem das prisões latino-americanas é escassa, entretanto é possível traçar um contorno geral tomando como apoio as relações entre o 
desenho e o funcionamento dos cárceres, as formas de castigo implementadas, os mecanismos de resistência adotados pelos presos e os meios de relação entre o Estado e a sociedade, que são refletidos pelos regimes penais. Tal escassez de informações também é mencionada por Cesar (2013) que considera, entre outras questões, a diversidade regional como um dos fatores que deixam as pesquisas ainda mais complexas. ${ }^{11}$

Maia et al. (2009) destacam que parte da produção brasileira sobre a temática das prisões, de forma geral, vem sendo realizada nos cursos de pós-graduação do país e por pesquisadores que trabalham com formas de controle social e que, por isso, têm interesse pelo assunto. No Estado do Rio de Janeiro as pesquisas na área da educação em prisões são encontradas em cursos de especialização, mestrado e doutorado, sendo bem limitado o debate nos cursos de graduação.

Entre os estudos que retratam a história das prisões cariocas se sobressaem os trabalhos desenvolvidos no âmbito do Programa de Pós-Graduação em Memória Social da Universidade do Estado do Rio de Janeiro (UNIRIO), na área de concentração de Estudos Interdisciplinares em Memória Social. As teses de doutorado de Elizabeth de Lima Gil Vieira (2014) e de José Paulo de Morais Souza (2017), e a dissertação de mestrado de José Mauro de Oliveira Braz (2016) são importantes referências no campo de pesquisa sobre a educação nas prisões do Estado do Rio de Janeiro.

É importante mencionar também o trabalho de Oliveira (2017) que chama a atenção para a responsabilidade das universidades públicas no enfrentamento do encarceramento em massa no sentido de suas ações não se limitarem às produções e às pesquisas acadêmicas, mas também que se voltem o olhar para o ensino superior e de extensão universitária.

A presença da universidade na prisão adequa-se às funções preventivas da pena privativa de liberdade e da própria execução penal, bem como condiz às funções da universidade pública, permitindo não só ampliar os alcances educativos, dos direitos humanos e da ampliação de oportunidades sociais às pessoas privadas de liberdade, mas também abrir novas discussões e perguntas à comunidade científica e ao papel da universidade pública. Esta presença da universidade, para além da pesquisa e de publicações acadêmicas, constitui-se como um dever e responsabilidade institucional, que pode induzir políticas públicas, promover novas relações no cotidiano do cárcere e potencializar diálogos, habilidades e competências, principalmente a partir da circulação de novos atores, informações e conhecimentos. (OLIVEIRA, C. 2017, 71-72).

\footnotetext{
${ }^{11}$ Para uma análise mais aprofundada sobre a historiografia das prisões, recomendamos os estudos de Aguirre (2009) e de Araújo (2009). Sobre a temática específica da história da educação em prisões, destacamos o trabalho de Souza (2017).
} 
Especificamente no Estado do Rio de Janeiro, as pesquisas em prisões esbarram numa série de empecilhos impostos pelo Governo e pelas suas instâncias de poder, principalmente no tocante ao acesso documental. A superlotação, as condições desumanas de tratamento as pessoas privadas de liberdade, os abusos e a insegurança dentro das prisões cariocas, se expostas de forma ampla, além de contrariarem as condições mínimas de exigências dos organismos internacionais, resultariam numa desmoralização ainda maior do Estado.

Na contramão disto desenvolvemos esse estudo. Todas as dificuldades aqui apresentadas podem ser motivo para falar sobre as prisões ou para se calar sobre o tema. Escolhemos a primeira opção. Desta forma, pretendemos contribuir para a compreensão de um objeto que, constantemente, constrange o sistema democrático da sociedade. Com toda a certeza, muitas experiências sobre as prisões se encontram adormecidas no passado, mas trazem reflexos até os dias de hoje.

\subsection{Bases teóricas fundamentais para o estudo das prisões}

Partindo do pressuposto de que o contexto carcerário só foi objeto de análises mais específicas a partir do final da década de 1970, com a chegada ao Brasil dos estudos de Max Weber, Michel Foucault e Erving Goffman voltados para o campo da sociologia, os objetivos dessa pesquisa consideram as principais posições que compreendem as teorias atuais a respeito das prisões, e que pretendemos analisar no decorrer do estudo.

A obra Vigiar e Punir, de Michel Foucault, é primordial para o estudo sobre a história das prisões, pois trata do nascimento do cárcere na França, entre o final do século XVIII e início do XIX, entretanto, Maia et al. (2009) chamam a atenção para o impacto que os textos de Foucault tiveram no Brasil. Os autores relatam que suas obras atraíram inúmeros seguidores que parecem ter evitado o cárcere como elemento de pesquisa, pois produziram muito sobre os mecanismos de controle no final dos anos 1970.

Segundo Maia et al. (2009), foi a ditadura militar, em seus momentos finais, que trouxe a temática da prisão para a realidade acadêmica. Neste momento não se tratava mais de uma discussão sobre disciplinar os corpos dos trabalhadores, mas da tortura de pessoas que eram por vezes da mesma origem social. Foi quando se fortaleceu o discurso sobre os direitos humanos na prisão, mas sem criticar o seu modelo. 
A impessoalidade das tecnologias e dos poderes de Foucault não parecia suficiente para falar de experiências tão pessoais, e talvez ainda mais difícil era lidar com o desejo de colocar ditadores e torturadores na prisão. Como utilizar a prisão e condená-la ao mesmo tempo? Ao contrário de temas médicos, a história das prisões de Foucault era inadequada às exigências imediatas da luta política e foi deixada à sombra. (MAIA et al., 2009, p.11)

Longe de fazer uma crítica às obras de Foucault, pretende-se aqui, refletir sobre as diferentes posturas dos historiadores diante do seu legado, trazendo assim um conjunto de possibilidades e de caminhos que são extremamente importantes na construção dos olhares possíveis sobre a temática da educação nas prisões.

Outro clássico da literatura sobre as prisões é o livro Dos delitos e das penas, de Cesare Beccaria, publicado no ano de 1764. Beccaria (2001) defendia a eliminação completa dos códigos criminais da época e de suas formas cruéis de punir os criminosos, sugerindo um novo sistema baseado em princípios mais humanitários. O autor denunciou torturas, maus tratos e abusos de poder, dando início à movimentos de reforma no sistema prisional.

Maia et al. (2009) explica que, em 1777, baseado nas ideias de Beccaria, John Howard publicou o livro The State of the Prisons in England and Wales relatando as péssimas condições das prisões britânicas e dando início a uma proposta de isolamento com trabalho, educação religiosa e moral, disciplina e classificação dos presos. Foi o responsável por levar ao Parlamento inglês ideias de importantes reformas inspiradas nas penitenciárias americanas e da Europa continental.

Jeremy Bentham, em 1785, idealizou um modelo de edifício com a função de recuperar os criminosos através de uma visão controladora de tudo e de todos: o Panóptico ${ }^{12}$. O desenho desse modelo permitia a um vigilante observar todos os prisioneiros, por meio de uma torre centra, sem que estes pudessem saber se estavam ou não sendo observados (MAIA et al., 2009).

\footnotetext{
12 Panóptico: pan- (todo) e optikós (visão).
} 
Figura 1 - Planta do Panóptico

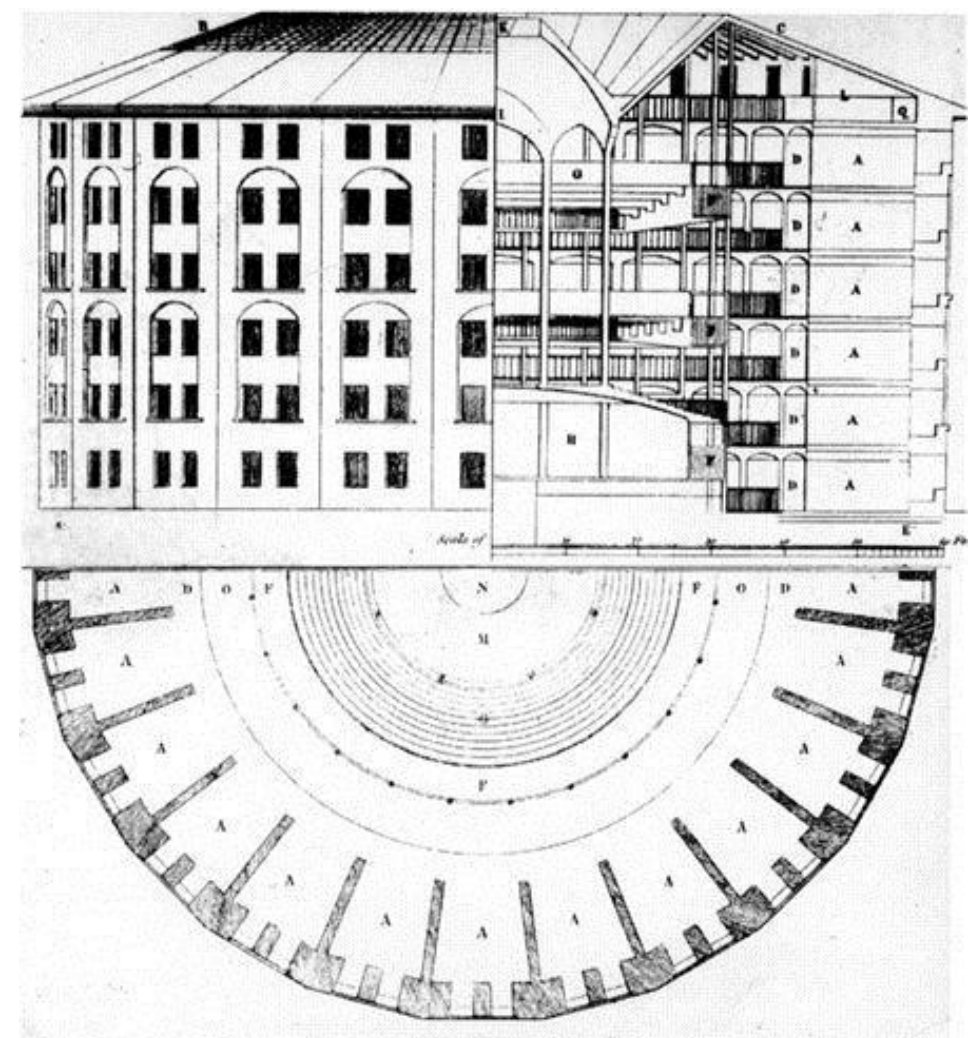

Fonte: FOUCAULT, M. Vigiar e Punir: nascimento da prisão. 40 ed. Petrópolis, RJ: Vozes, 2012. Anexos.

Segundo Maia et al. (2009) no século XIX foram criados nos Estados Unidos os primeiros sistemas prisionais tendo o isolamento, o silêncio e o trabalho como fatores primordiais da pena de prisão, levando à construção de penitenciárias no estilo Panóptico que consagraram dois modelos de execução da pena: o sistema da Pensilvânia e o sistema de Auburn.

Melossi (2006) explica que nos Estados Unidos, no estado quaker ${ }^{13}$ da Pensilvânia, surgiu uma instituição carcerária com regime de isolamento celular contínuo que tinha como base o trabalho completamente espiritual e que não atribuía nada ao trabalho produtivo. Já em Auburn o trabalho era o alicerce das penas que eram compostas por isolamento noturno e por afazeres diurno em silêncio. Este sistema, por sua vez, foi o que prevaleceu na América devido a maior necessidade de mão de obra, ao contrário da Europa.

\footnotetext{
${ }^{13}$ Quaker são grupos religiosos que se originaram do movimento protestante britânico do século XVII. O movimento quaker foi criado em 1652, pelo inglês George Fox, e pretendeu ser a restauração da fé cristã original. Também conhecido como "Sociedade dos Amigos", o grupo reagiu contra o que considerava abusos da Igreja Anglicana, rejeitando qualquer organização clerical. Em 1681, emigraram para os Estados Unidos onde criaram a colônia da Pensilvânia.
} 
A exploração da mão de obra prisional se fundamentava na ideia de que o Estado não deveria custear o sustento dos presos, como explicam Maia et al. (2009). O trabalho nas prisões era visto como fator fundamental para a reintegração do indivíduo que, se ocupado, não colocaria a sua energia em pensamentos criminosos.

Mais tarde, no século XIX, o sistema de Auburn trouxe o problema da concorrência entre a mão de obra barata e os trabalhadores assalariados, passando a ideia de que a prisão era um lugar onde os criminosos tinham casa, comida e emprego, diferente daqueles que não cometeram crime algum.

Os sistemas da Pensilvânia e de Auburn foram bastante criticados devido à forma de tratamento dado aos presos. Segundo Maia et al. (2009), com o fracasso dessas experiências foram criados na Europa os sistemas progressivos com um novo diferencial: a participação dos detentos na transformação de sua pena. O bom comportamento começou a ser um fator significativo na redução da pena, além de contribuir para uma melhor condição dentro dos presídios. Esses sistemas progressivos foram experimentados pela primeira vez no ano de 1835, na Espanha, na cidade de Valência.

Dario Melossi e Massimo Pavarini, na obra Cárcere e Fábrica, analisaram os percursos que deram origem ao regime da força de trabalho na prisão, levando em consideração o papel da família, da escola e de outras instituições sociais, a exemplo da igreja. ${ }^{14}$ Ao estudarem os sistemas prisionais da Inglaterra, da Holanda, da Itália e dos Estados Unidos, os autores concluem que a relação capital/trabalho assalariado possui um papel de extrema relevância no entendimento sobre a própria criação das instituições carcerárias. Neste sentido, para eles a privação de liberdade esteve diretamente ligada ao capitalismo.

Sociólogos atentos aos problemas contemporâneos começam a publicar trabalhos importantes sobre as prisões. No ano de 1958, Gresham Sykes lança a obra A sociedade dos cativos, trazendo reflexões a respeito das diversas formas de organização social que surgiram no interior dos sistemas penais com o papel de articular rígidos códigos de condutas, criando uma sociedade dentro da sociedade.

Em 1961 surge a primeira edição de Manicômios, prisões e conventos, escrito por Erving Goffman. Nesta obra ele compreende como um processo de mortificação do "eu" o momento em que o indivíduo é admitido numa "instituição total” como a prisão.

\footnotetext{
${ }^{14}$ Sobre a temática da religião no sistema prisional, ver GAMA (2017).
} 
A instituição total pode ser definida como um local de residência e trabalho onde um grande número de indivíduos com situação semelhante, separados da sociedade mais ampla por considerável período de tempo, levam uma vida fechada e formalmente administrada. (GOFFMAN, 2013, p.11)

Goffman (2013) divide as “instituições totais” em cinco grupos. O primeiro deles é onde se inserem as instituiçõos destinadas a cuidar de pessoas incapazes e inofensivas, como as casas para idosos, órfãos, indigentes e pessoas com deficiência. No segundo grupo estão os locais direcionados aos incapazes que são, de maneira não intencional, considerados uma ameaça à sociedade. Segundo o autor, são exemplos de instituições deste grupo os sanatórios para tuberculosos e os hospitais para doentes mentais e leprosários. Em terceiro lugar estão os estabelecimentos de proteção da sociedade contra os perigos intencionais, como as cadeias, penitenciárias, campos de prisioneiros de guerra e campos de concentração. Um quarto grupo destina-se a realizar com seus internos, alguma tarefa de trabalho, como é o caso dos quartéis, navios, escolas internas, colônias, entre outros. Em quinto e último lugar, há os estabelecimentos que servem como refúgio do mundo e como locais de instrução para os religiosos, tais como os mosteiros, os conventos e as abadias.

No processo de mortificação do "eu”, segundo Goffman (2013), os novatos chegam às “instituições totais" com uma concepção de si mesmos, criada devido a algumas disposições presentes no meio social. Ao se inserirem na instituição, se despem do apoio dado por tais disposições e recebem uma série de rebaixamentos, humilhações e degradações do "eu", que se mortifica. A partir disto, podemos refletir sobre o papel da educação no sistema prisional como uma tentativa de contribuir para o resgate do "eu" mortificado, possibilitando a construção de sujeitos autônomos e capazes de identificar novas alternativas de vida após a prisão.

Apesar da obra de Goffman ter sido responsável por uma nova história das instituições penais, foi Michel Foucault o filósofo que mais influenciou os estudos sobre as prisões. Em Vigiar e Punir Foucault traz o debate sobre a prisão e sua função corretiva em meio ao que chamou de “sociedade disciplinar". Acreditava na transformação do homem através da sujeição da disciplina do corpo onde era possível, através de uma série de saberes/poderes, separar indivíduos confusos e desordenados e transformá-los em corpos dóceis e obedientes. Sobre a obra de Foucault Maia et al. (2009, p. 20) faz a seguinte indagação: "No caso do Brasil, por exemplo, como estudá-lo 
utilizando apenas o modelo de modo de produção capitalista, uma vez que nossa sociedade ainda estava numa fase pré-burguesa?".

Diante dos trabalhos de Goffman e de Foucault, o estudo de David Rothman intitulado The Discovery of the Asilum e publicado no ano de 1971, ficou quase esquecido no Brasil. Como apontam Maia et al. (2009), trata-se de um trabalho que se contrapunha às pesquisas de décadas anteriores que viam a prisão como algo humanitário em substituição ao castigo físico. Novas pesquisas tinham como objetivo a inserção da temática das prisões em um contexto social mais amplo, incluindo fatores culturais, políticos e religiosos.

As bases teóricas de Goffman, de Foucault e de todos os outros autores da época se complementam mais do que se excluem pois trazem diversos olhares e inúmeras possibilidades de interpretação sobre as instituições prisionais do Ocidente que serviram de norte para os estudos das prisões do Brasil.

\subsection{O passado e o presente: concepções históricas sobre as prisões no Brasil}

Destacamos que o motivo que levou a implementação dos modelos penitenciários na América Latina não se assemelha aos dos modelos europeu ou norte-americano. Isso se deu porque, durante o período colonial, as prisões não tinham importância para as autoridades, pois não faziam parte do esquema punitivo da época, que era pautado apenas na fase de execução da sentença. Segundo Aguirre (2009, p. 38), "O castigo, de fato, se aplicava muito mais frequentemente por meio de (...) execuções públicas, marcas, açoites, trabalhos públicos ou desterros.". As prisões se destinavam apenas para resguardar os criminosos até a fase do julgamento, e não como parte primordial da pena.

Para Aguirre (2009), somente no início do século XIX, com a implementação do modelo de penitenciária na Europa e nos Estados Unidos, baseando-se nas penas regimentadas pelo trabalho, as autoridades da América Latina começaram a discutir a possibilidade de uma reforma carcerária.

Ente os anos de 1747 e 1808, conforme aponta Souza (2017), foram criadas no Rio de Janeiro diversas prisões militares espalhadas pela baía de Guanabara, como é o caso da Ilha das Cobras, da Fortaleza de Santiago e da Fortaleza de Santa Bárbara. Também se destacam como 
prisões da época, a Cadeia Pública do edifício do Senado da Câmara e o Calabouço, localizado na fortaleza de Santiago.

No ano de 1830, o primeiro Código Criminal Brasileiro foi promulgado instituindo a pena de privação de liberdade e a prisão com trabalho, destinadas a vários delitos que, antes disto, dispensavam o cárcere. Segundo Cesar (2012), ficou notório o interesse do Estado em controlar a população livre e estender seu poder a justiça penal. No entanto, em grande parte dos Municípios do Império não existiam cadeias suficientes para comportar todos os delinquentes que estiveram em livramento ou condenados à prisão simples.

Em 1834 se iniciou a construção da primeira penitenciária da América Latina, a Casa de Correção do Rio de Janeiro. A Sociedade Defensora da Liberdade e Independência Nacional, instalada no Rio de Janeiro em 19 de maio de 1831, deu o primeiro passo no tocante a criação da Casa de Correção, pois, por possuir uma vertente teórica liberal moderada, se preocupava com a permanência do Império e com a ordem pública que, naquele momento, passava por um processo de desestruturação (SANT'ANNA, M. A., 2009). Mais tarde, somente no ano de 1850, a penitenciária é inaugurada, revelando as dificuldades políticas e financeiras pelas quais os reformadores passaram.

Conforme Chazkel (2009), a Casa de Correção foi inspirada nos estabelecimentos carcerários dos Estados Unidos com as recomendações publicadas pela Inglaterra, entretanto, devido ao orçamento disponível na época, só foi possível construir duas das quatro partes do plano panóptico. 
Figura 2 - Planta da Casa de Correção da Corte (1834)

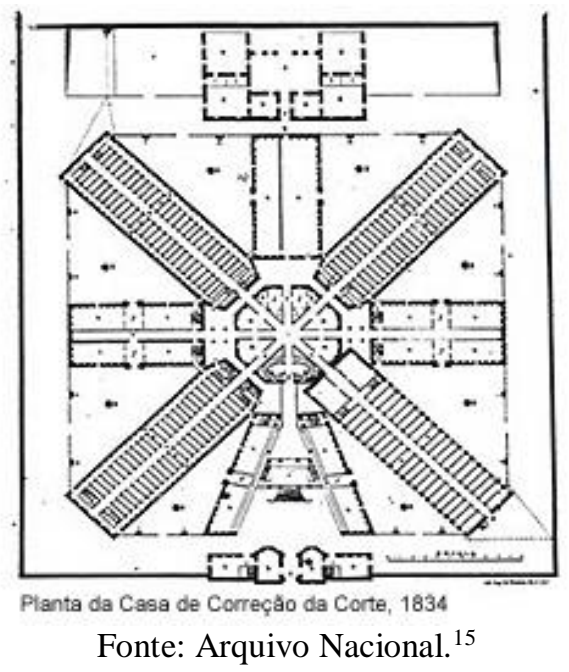

Refletindo a mudança doutrinal de um modelo prisional estritamente punitivo para o ideal de regeneração por meio do trabalho árduo, a Casa de Correção, conforme aponta Chazkel (2009), foi concebida para acomodar detentos sentenciados à "prisão com trabalho". O edifício tinha pátios, oficinas e outras áreas comuns, assim como celas individuais que visavam pôr em prática o regime híbrido de isolamento e socialização que a nova filosofia penal requeria.

Em 1856 foi construída a partir de uma parte do andar térreo da Casa de Correção, uma Casa de Detenção com capacidade para 160 detentos. Mais tarde, em 1888, uma legislação determinou que a Casa de Correção deveria conter somente condenados à prisão com trabalho, ao passo que a Casa de Detenção deveria abrigar presos cujas sentenças eram de "prisão simples". Neste sentido, a Casa de Detenção misturava prisioneiros acusados de diversos delitos, além de escravos e homens livres.

No ano de 1890, o decreto 774 revogou as penas de morte, galés e açoites, e o Código Penal da República dos Estados Unidos do Brasil, de 11 de outubro de 1890, instituiu as penas de prisão celular, reclusão, prisão com trabalho e prisão disciplinar, além dos regimes penitenciários; sem fazer modificações internas nos estabelecimentos penais.

Conforme os estudos de Vasconcelos (2000), em 1902 se inicia uma reforma do Sistema Policial do Distrito Federal através da Lei no 947 , de 29 de dezembro. Com isso são criadas as

\footnotetext{
${ }^{15}$ Disponível em:<http://mapa.an.gov.br/index.php/menu-de-categorias-2/268-casa-de-correcao>. Acesso em 11 out. 2019.
} 
Colônias Correcionais que tinham o objetivo reabilitar os mendigos, vagabundos ou vadios, capoeiras e os menores viciosos por meio do trabalho e da instrução.

Mais tarde a Constituição de 1934 estendeu os direitos sociais aos trabalhadores, reconhecendo não apenas os direitos do capital, mas também os direitos do trabalho. Também em 1934 foi criada a Inspetoria Geral Penitenciária com diversos objetivos, entre eles o de "expedir instruções e providências para a execução das reformas de prevenção, de reeducação e penais em todo o Brasil" $" 16$.

Em 1940 um novo Código Penal foi criado pelo presidente Getúlio Vargas, substituindo o Código de 1890. Apesar de ter sido elaborado em 1940, o atual Código Penal Brasileiro só entrou em vigor no ano de 1942, depois de amplos debates sobre diversos temas em que fazia referência. Embora seja considerado extenso, o código não esgotou todas as questões penais previstas na legislação brasileira, visto a quantidade surpreendente de leis penais especiais em vigor nos dias de hoje.

Já o Código de Processo Penal teve sua primeira reforma no ano de 1832, pelo Padre Diogo Feijó, um dos fundadores do Partido Liberal. Em 1941, durante o período do Estado Novo, o então vigente Código de Processo Penal Brasileiro foi redigido pelo jurista Francisco Campos, também autor da Constituição Federal de 1937 e do Código Penal de 1940. Contudo, assim como no Código Penal, existem várias incompatibilidades entre o Código Processual de 1941 e a Constituição Federal de 1988.

Entre as inúmeras leis que complementam o Código Penal e o Código de Processo Penal, está a Lei de Execução Penal - LEP (Lei 7210/84), criada no ano de 1984 com o objetivo de "efetivar as disposições de sentença ou decisão criminal e proporcionar condições para a harmônica integração social do condenado e do internado", conforme a redação do seu artigo primeiro. Uma das propostas da LEP é a valorização dos direitos humanos das pessoas privadas de liberdade, proporcionando um tratamento individualizado através da garantia de assistência material, à saúde, jurídica, educacional, social e religiosa.

Apesar de no Brasil os estados possuírem autonomia para administrar suas penitenciárias, cadeias e delegacias, a LEP materializou, em seu artigo $86, \S^{\circ}$, a criação do Sistema Penitenciário Federal, responsável pelo isolamento dos presos considerados mais perigosos. Segundo o Decreto

\footnotetext{
${ }^{16}$ Decreto $\mathrm{n}^{\circ}$ 1.441, de 8 de Fevereiro de 1937. Disponível em <https://www2.camara.leg.br/legin/fed/decret/1930-
} 1939/decreto-1441-8-fevereiro-1937-458648-publicacaooriginal-1-pe.html> Acesso em 03 abr. 2019. 
6.049, de 27 de fevereiro de 2007, que aprovou o Regulamento Penitenciário Federal, os estabelecimentos penais federais têm a finalidade de promover a execução administrativa das medidas restritivas de liberdade dos presos provisórios ou condenados; e também abrigar os presos sujeitos ao regime disciplinar diferenciado, previsto na LEP. A inclusão dos detentos no Sistema Penitenciário Federal justifica-se no interesse da segurança pública ou do próprio preso.

O Sistema Penitenciário Federal é subordinado ao Departamento Penitenciário Nacional DEPEN, do Ministério da Justiça; e atualmente é constituído por 5 (cinco) unidades prisionais: Catanduvas (PR), Campo Grande (MS), Porto Velho (RO), Mossoró (RN) e Brasília (DF).

O estudo de Carvalho (2014) relata o rígido controle dos estabelecimentos prisionais federais.

As celas são individuais e, como são construídas em concreto puro, até a lâmpada do teto é protegida por blindagem de ferro. Nelas não há qualquer objeto que possa ser arrancado para ser usado como arma. Para se chegar a qualquer cela é necessário, antes, passar por 17 portões eletrônicos de ferro. (CARVALHO, 2014, p. 86)

Segundo dados do DEPEN (BRASIL, INFOPEN, 2017), em junho de 2016 quatro unidades federais custodiavam um total de 437 pessoas privadas de liberdade. Ao todo, as unidades somavam 832 vagas, o que corresponde a uma taxa de ocupação de 52,5\%. Entretanto, essa não é a mesma realidade das unidades prisionais estaduais que somam 367.217 vagas em todo o país e compõem um déficit de 359.058 vagas.

Tabela 1 - Capacidade do sistema prisional e déficit de vagas por UF (2016)

\begin{tabular}{|c|c|c|c|}
\hline ESTADO & $\begin{array}{c}\text { POPULAÇÃO } \\
\text { PRISIONAL }\end{array}$ & $\begin{array}{c}\text { NÚMERO DE } \\
\text { VAGAS }\end{array}$ & DEFICIT \\
\hline Acre & 5.364 & 3.143 & 2.221 \\
\hline Alagoas & 6.957 & 2.845 & 4.112 \\
\hline Amapá & 2.680 & 1.388 & 1.292 \\
\hline Amazonas & 11.390 & 2.354 & 9.036 \\
\hline Bahia & 15.294 & 6.831 & 8.463 \\
\hline Ceará & 34.566 & 11.179 & 23.387 \\
\hline Distrito Federal & 15.194 & 7.229 & 7.965 \\
\hline Espírito Santo & 19.413 & 13.417 & 5.996 \\
\hline Goiás & 16.917 & 7.150 & 9.767 \\
\hline Maranhão & 8.835 & 5.293 & 3.542 \\
\hline Mato Grosso & 10.362 & 6.369 & 3.993 \\
\hline Mato Grosso do Sul & 18.688 & 7.731 & 10.957 \\
\hline Minas Gerais & 68.354 & 36.556 & 31.798 \\
\hline Pará & 14.212 & 8.489 & 5.723 \\
\hline
\end{tabular}




\begin{tabular}{|c|c|c|c|}
\hline Paraíba & 11.377 & 5.241 & 6.136 \\
\hline Paraná & 51.700 & 18.365 & 33.335 \\
\hline Pernambuco & 34.556 & 11.495 & 23.061 \\
\hline Piauí & 4.032 & 2.363 & 1.669 \\
\hline Rio de Janeiro & 50.219 & 28.443 & 21.776 \\
\hline Rio Grande do Norte & 8.809 & 4.265 & 4.544 \\
\hline Rio Grande do Sul & 33.868 & 21.642 & 12.226 \\
\hline Rondônia & 10.832 & 4.969 & 5.863 \\
\hline Roraima & 2.339 & 1.198 & 1.141 \\
\hline Santa Catarina & 21.472 & 13.870 & 7.602 \\
\hline São Paulo & 240.061 & 131.159 & 108.902 \\
\hline Sergipe & 5.316 & 2.251 & 3.065 \\
\hline Tocantins & 3.468 & 1.982 & 1.486 \\
\hline TOTAL & $\mathbf{7 2 6 . 2 7 5}$ & $\mathbf{3 6 7 . 2 1 7}$ & $\mathbf{3 5 9 . 0 5 8}$ \\
\hline
\end{tabular}

Fonte: Levantamento Nacional de Informações Penitenciárias (BRASIL, INFOPEN, 2017, p. 20)

As prisões das principais cidades brasileiras talvez se assemelhem ainda às prisões coloniais, construídas para abrigar escravos no século XVIII. As políticas públicas adotadas pelo Governo Federal para a questão penitenciária são, até hoje, incapazes de resolver os inúmeros problemas que aparecem a todo o momento nas prisões do país. Entre 2000 e 2016, a taxa de aprisionamento aumentou em 157\% no Brasil. Em 2000 existiam 137 pessoas presas para cada grupo de 100 mil habitantes. Em Junho de 2016, eram 352,6 pessoas presas para cada 100 mil habitantes, conforme dados do DEPEN (2016).

Gráfico 1 - Evolução da taxa de aprisionamento no Brasil entre 2000 e 2016

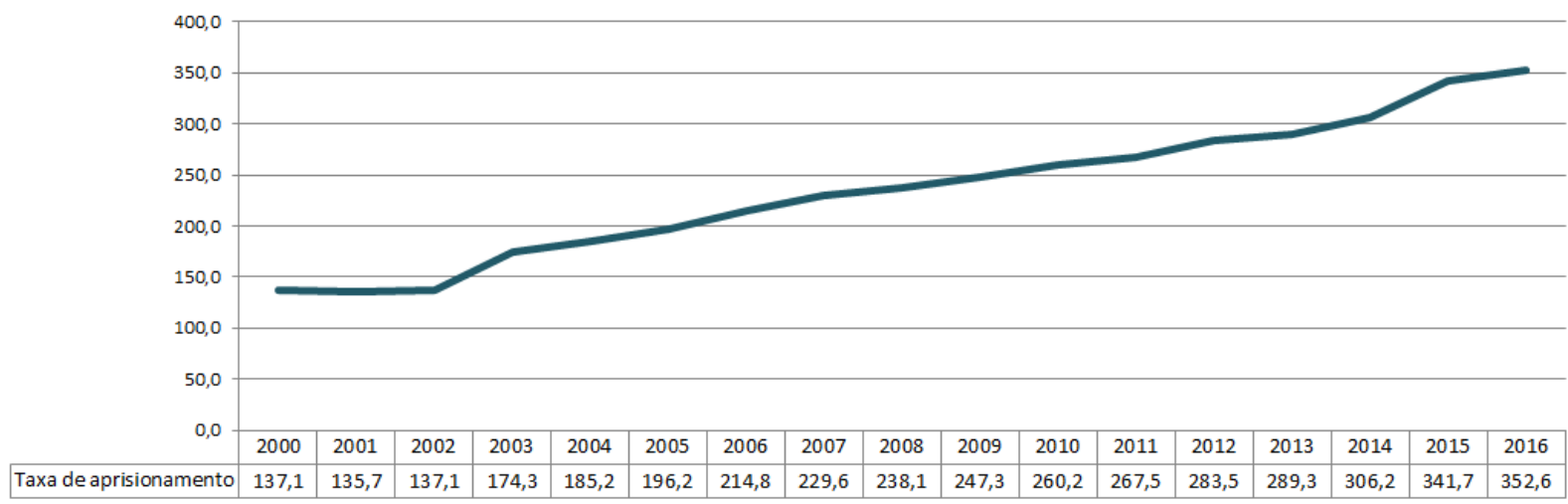

Fonte: Levantamento Nacional de Informações Penitenciárias (BRASIL, INFOPEN, 2017, p. 12) 
A maioria da população prisional do Brasil é composta por jovens, pobres e negros. Segundo o DEPEN (2016), 55\% dos presos brasileiros são jovens ${ }^{17}$ com idade entre 18 e 29 anos e 64\% são negros. Traçando um comparativo com a população brasileira acima de 18 anos, em 2015, a parcela negra representava 53\%.

Carlos Aguirre (2009), ao estudar o cárcere na América Latina entre os anos 1800 e 1940 relata que, naquela época, os preconceitos raciais já influíam no modo como os presos negros e indígenas eram tratados pelas autoridades. Segundo o autor, mesmo que as prisões não tivessem sido idealizadas como instituições racialmente segregadas, elas reproduziam em seu funcionamento as estruturas raciais das sociedades latino-americanas.

Uma pesquisa do Núcleo de Estudos da Violência da Universidade de São Paulo publicada por Adorno (1996) aponta que não há diferenças entre o "potencial" para o crime violento praticado por delinquentes negros comparativamente aos brancos, mas indica que réus negros tendem a serem mais perseguidos pela polícia e possuem maior dificuldade em usufruir dos direitos assegurados pela Constituição Federal (1988).

(...) as sentenças condenatórias se inclinam a privilegiar os roubos qualificados cometidos por réus negros. Tudo parece indicar, portanto, que a cor é poderoso instrumento de discriminação na distribuição da justiça. O princípio da equidade de todos perante às leis, independentemente das diferenças e desigualdades sociais, parece comprometido com o funcionamento viesado do sistema de justiça criminal.

(ADORNO, 1995, p. 63)

O perfil de escolarização da população prisional brasileira também nos traz elementos alarmantes. Os dados expressam que 75\% das pessoas privadas de liberdade ainda não acessou o ensino médio, tendo concluído, no máximo, o ensino fundamental. Entre a população que se encontra no ensino médio, tendo concluído ou não esta etapa da educação formal, temos $24 \%$ da população privada de liberdade. $4 \%$ da população prisional brasileira é analfabeta.

\footnotetext{
${ }^{17}$ Classificação dada pelo Estatuto da Juventude (Lei no ${ }^{\circ}$ 12.852/2013).
} 
Gráfico 2 - Escolaridade das pessoas privadas de liberdade no Brasil
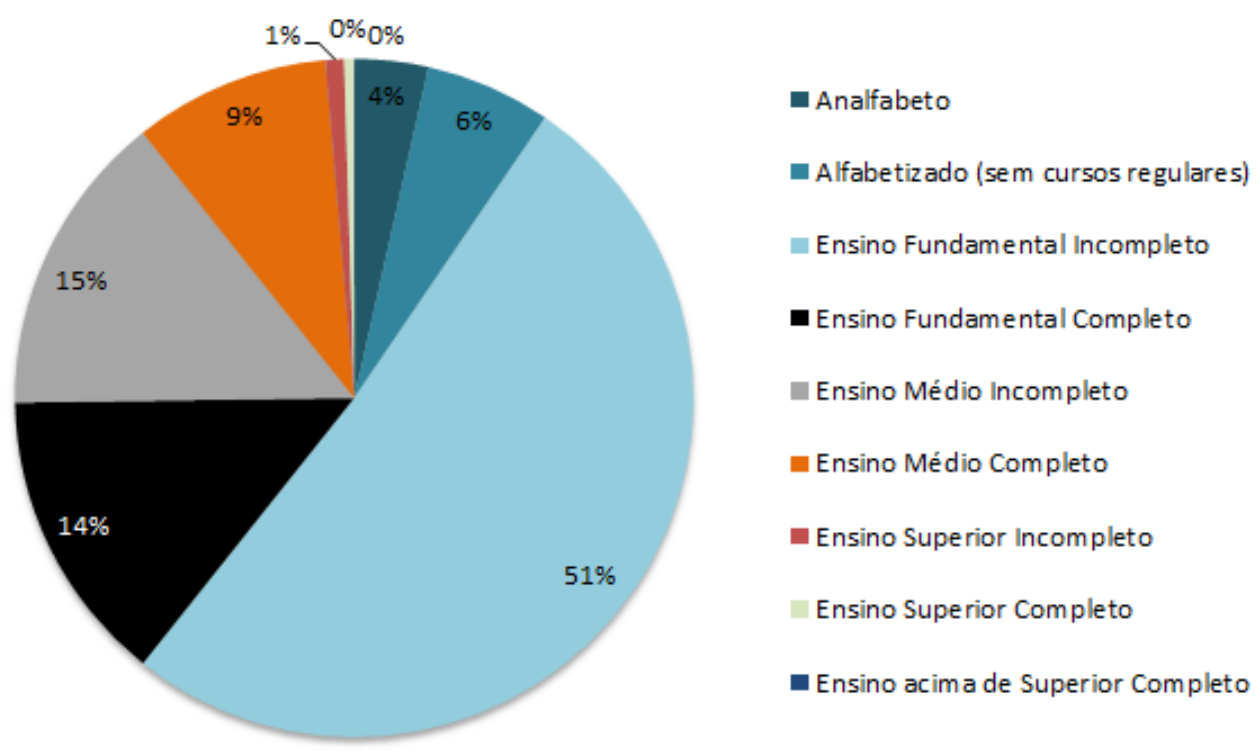

Fonte: Levantamento Nacional de Informações Penitenciárias (BRASIL, INFOPEN, 2017, p.33.)

Por outro lado, os dados estatísticos que balizam o total de pessoas presas envolvidas em atividades educacionais também merecem destaque. No levantamento apresentado pelo DEPEN (BRASIL, INFOPEN, 2017) foram discriminadas entre atividades de ensino escolar, que compreendem as atividades de alfabetização, formação de ensino fundamental até ensino superior, cursos técnicos (acima de 800 horas de aula) e curso de formação inicial e continuada (capacitação profissional, acima de 160 horas de aula); e atividades complementares, que compreendem as pessoas matriculadas em programas de remição pelo estudo por meio da leitura, pessoas matriculadas em programas de remição pelo estudo por meio do esporte e pessoas envolvidas em demais atividades educacionais complementares (tais como, videoteca, atividades de lazer e cultura).

Apenas $12 \%$ da população prisional no Brasil está envolvida em algum tipo de atividade educacional, entre aquelas de ensino escolar e atividades complementares. Vale destacar que tratase de uma população que, em sua maioria, é composta por jovens, pobres e negros que não tiveram acesso e permanência à escolarização na idade adequada. 
Tabela 2 - Pessoas privadas de liberdade envolvidas em atividades educacionais por UF (2016)

\begin{tabular}{|c|c|c|c|c|c|}
\hline \multirow[b]{2}{*}{ UF } & \multicolumn{2}{|c|}{$\begin{array}{c}\text { Pessoas em atividades de ensino } \\
\text { escolar }\end{array}$} & \multicolumn{2}{|c|}{$\begin{array}{l}\text { Pessoas em atividades educacionais } \\
\text { complementares }\end{array}$} & \multirow{2}{*}{$\begin{array}{c}\% \text { total de pessoas presas em } \\
\text { atividades educacionais }\end{array}$} \\
\hline & $\mathbf{N}$ & $\%$ & $\mathbf{N}$ & $\%$ & \\
\hline$A C$ & 226 & $4 \%$ & 0 & $0 \%$ & $4 \%$ \\
\hline AL & 367 & $6 \%$ & 0 & $0 \%$ & $6 \%$ \\
\hline AM & 907 & $9 \%$ & 50 & $0 \%$ & $9 \%$ \\
\hline AP & 49 & $2 \%$ & 0 & $0 \%$ & $2 \%$ \\
\hline BA & 2.296 & $18 \%$ & 168 & $1 \%$ & $20 \%$ \\
\hline CE & 1.701 & $7 \%$ & 0 & $0 \%$ & $7 \%$ \\
\hline DF & 1.600 & $11 \%$ & 22 & $0 \%$ & $11 \%$ \\
\hline ES & 3.660 & $19 \%$ & 817 & $4 \%$ & $23 \%$ \\
\hline GO & 506 & $3 \%$ & 23 & $0 \%$ & $3 \%$ \\
\hline MA & 887 & $12 \%$ & 95 & $1 \%$ & $13 \%$ \\
\hline MG & 8.060 & $13 \%$ & 1.838 & $3 \%$ & $15 \%$ \\
\hline MS & 1.239 & $7 \%$ & 32 & $0 \%$ & $7 \%$ \\
\hline MT & 1.316 & $13 \%$ & 111 & $1 \%$ & $14 \%$ \\
\hline PA & 1.259 & $9 \%$ & 0 & $0 \%$ & $9 \%$ \\
\hline PB & 1.089 & $10 \%$ & 0 & $0 \%$ & $10 \%$ \\
\hline PE & 5.062 & $15 \%$ & 12 & $0 \%$ & $15 \%$ \\
\hline PI & 382 & $9 \%$ & 50 & $1 \%$ & $11 \%$ \\
\hline PR & 5.723 & $14 \%$ & 2.316 & $6 \%$ & $19 \%$ \\
\hline RJ & $\mathrm{NI}$ & $\mathrm{NI}$ & $\mathrm{NI}$ & $\mathrm{NI}$ & NI \\
\hline RN & 87 & $1 \%$ & 48 & $1 \%$ & $2 \%$ \\
\hline RO & 976 & $9 \%$ & 191 & $2 \%$ & $11 \%$ \\
\hline RR & 330 & $14 \%$ & 0 & $0 \%$ & $14 \%$ \\
\hline RS & 2.185 & $6 \%$ & 158 & $0 \%$ & $7 \%$ \\
\hline SC & 1.945 & $9 \%$ & 839 & $4 \%$ & $13 \%$ \\
\hline SE & 240 & $5 \%$ & 15 & $0 \%$ & $5 \%$ \\
\hline SP & 19.092 & $8 \%$ & 5.706 & $2 \%$ & $10 \%$ \\
\hline TO & 458 & $13 \%$ & 407 & $12 \%$ & $25 \%$ \\
\hline Brasil & 61.642 & $10 \%$ & 12.898 & $2 \%$ & $12 \%$ \\
\hline
\end{tabular}

Fonte: Levantamento Nacional de Informações Penitenciárias (INFOPEN, BRASIL, 2017, p.33.)

Como é possível notar, o Rio de Janeiro foi o único estado que não informou os dados sobre a população envolvida em atividades de ensino e, assim, sua população prisional não foi considerada no cálculo percentual total ${ }^{18}$. Entretanto, na fase de coleta dos dados documentais para o desenvolvimento desta pesquisa, apesar das dificuldades já relatadas, tivemos acesso ao Plano Estadual de Educação em Prisões (PEEP) com todos os dados estatísticos atualizados no ano de 2018, exclusivamente para esta tese.

Para esta análise inicial, tomaremos como base as seguintes tabelas:

18 Este fato também ocorreu no levantamento elaborado pelo DEPEN no ano de 2015, disponível em <http://depen.gov.br/DEPEN/depen/sisdepen/infopen/relatorios-sinteticos/relatorio_2015_2311.pdf> Acesso em 03 abr. 2019. 
Tabela 3 - Quantidade de presos no sistema prisional do Estado do Rio de Janeiro (2018)

\begin{tabular}{||l||c||}
\hline \multicolumn{1}{|c||}{$\begin{array}{c}\text { Referência - Quantidade de Presos no Sistema } \\
\text { Penitenciário }\end{array}$} & Quantidade \\
\hline Presos Provisórios & 20.456 \\
\hline Regime Fechado & 18.220 \\
\hline Regime Semiaberto & 12.017 \\
\hline Regime Aberto & 723 \\
\hline Medida de Segurança - Internação $\quad$ TOTAL & 53 \\
\hline \multicolumn{2}{|c|}{} \\
\hline
\end{tabular}

Fonte: Plano Estadual de Educação em Prisões (RIO DE JANEIRO, 2018, p.13)

Tabela 4 - Quantidade de presos em atividade escolar no sistema prisional do Estado do Rio de Janeiro (2018)

\begin{tabular}{||l|c|}
\hline \multicolumn{1}{|c|}{ Escolaridade } & Atendimento \\
\hline Alfabetização & 149 \\
\hline Ensino Fundamental (Anos Iniciais) & 602 \\
\hline Ensino Fundamental (Anos Finais) & 1453 \\
\hline Ensino Fundamental (Total) & 2204 \\
\hline Ensino Médio & 938 \\
\hline Ensino Superior & 0 \\
\hline \multicolumn{1}{|c|}{ TOTAL } & 3142 \\
\hline
\end{tabular}

Fonte: Plano Estadual de Educação em Prisões (RIO DE JANEIRO, 2018, p.40)

Segundo o PEEP (RIO DE JANEIRO, 2018) o Estado do Rio de Janeiro possui 51.469 pessoas privadas de liberdade e apenas 3.142 estão envolvidos em atividades de ensino escolar, o que equivale à aproximadamente 6\%. Considerando os dados do DEPEN (BRASIL, INFOPEN, 2017) presentes na tabela 2, o percentual do Rio de Janeiro representaria uma redução de $1 \%$ no percentual total de "pessoas em atividade de ensino escolar" no Brasil. Desta forma, ocorreria uma queda de $10 \%$ para $9 \%$.

Cabe observar também que, no Levantamento Nacional de Informações Penitenciárias elaborado pelo DEPEN em dezembro de $2014^{19}$, o Estado do Rio de Janeiro informou possuir na ocasião, 5.014 pessoas envolvidas em atividades de ensino escolar nas prisões, o que representava

19 O Levantamento Nacional de Informações Penitenciárias de dezembro de 2014 está disponível em 〈http://depen.gov.br/DEPEN/depen/sisdepen/infopen/relatorios-sinteticos/copy_of_infopen_dez14.pdf>. Acesso em 03/04/2019, às 20:18h. 
$12 \%$ de um total de 40.301 pessoas privadas de liberdade em 2014. Comparando com os dados apresentados pela SEEDUC/RJ para esta pesquisa, temos uma redução da metade do percentual (6\%) 4 (quatro) anos após o levantamento do DEPEN.

\section{3- Breve histórico sobre a educação no Sistema Prisional do Estado do Rio de Janeiro}

A preocupação com a recuperação dos detentos através de políticas públicas como a educação e o trabalho, sempre foi deixada de lado. A “assistência educacional”, principal foco deste estudo, compreende a instrução escolar e a formação profissional do preso e do interno, tornando obrigatório o ensino fundamental, integrando-se no sistema escolar estadual. O ensino profissional, por sua vez, deve ser ministrado em nível de iniciação ou de aperfeiçoamento técnico, conforme estabelecido pela LEP.

Contudo, a implementação das políticas públicas de execução penal no Brasil é de responsabilidade de cada estado. Julião (2003) aponta que, por isso, devido à diversidade cultural, econômica e social do país, a realidade penitenciária brasileira varia muito de região para região. Segundo o referido autor, existem dificuldades, por parte dos estados, em cumprir o que determina a LEP, até mesmo no que diz respeito à oferta do ensino fundamental aos detentos.

As Diretrizes Nacionais para a Oferta da Educação em Estabelecimentos Penais (BRASIL, 2010), aprovadas pela Resolução no 3, de 11 de março de 2009, do Conselho Nacional de Política Criminal e Penitenciária (CNPCP), fizeram com que novos caminhos de discussão fossem abertos em torno da pertinência de um Projeto Político Pedagógico (PPP) para o sistema penitenciário brasileiro, inspirado na Lei de Diretrizes e Bases da Educação e na Lei de Execuções Penais. Uma consequência prática destas normas é a obrigatoriedade de que cada estado formule seu Plano Estadual de Educação nas Prisões e, consequentemente, o PPP.

Na década de 1960, surgiu a Superintendência do Sistema Penitenciário (SUSIPE) que, mais tarde, em 1975, reformulou sua estrutura administrativa passando a se chamar Departamento de Administração Penitenciária (DESIPE) e, em 2003, Secretaria do Estado de Administração Penitenciária (SEAP), sendo responsável por todas as unidades prisionais do Estado.

O Estado do Rio de Janeiro, desde 1967, vêm desenvolvendo ações na área educacional quando a então Superintendência do Sistema Penitenciário (SUSIPE) firmou parceria com a Secretaria de Estado de Educação (SEEDUC). Na ocasião foram criadas 6 (seis) Classes de Cooperação (CCs) que levavam o nome das suas respectivas penitenciárias e ofereciam o ensino 
da Alfabetização à $4^{\mathrm{a}}$ série (atualmente do $1^{\mathrm{o}}$ ao $5^{\circ}$ ano) (RIO DE JANEIRO, 2018). Segundo os estudos de Julião (2003) no ano de 1967 foi inaugurado o primeiro Colégio formal dentro de uma unidade prisional no país: o Colégio Estadual Mario Quintana, localizado na antiga Penitenciária Lemos Brito, no Complexo da Frei Caneca, região central do Rio de Janeiro.

Até 1967, as atividades educacionais funcionavam nos presídios com internos dando aulas e não professores formados. Segundo a professora Deise P. Martins, ex-chefe da Seção de Educação da ex-Penitenciária Cândido Mendes na Ilha Grande , em virtude da distância e da falta de profissionais interessados em trabalhar na área educacional da Penitenciária, os presos políticos que lá estavam davam aulas para os internos penitenciários, alunos da sua escola. (JULIÃO, 2003, p. 53)

A SEEDUC se comprometeu a instalar escolas nas Unidades Prisionais, oferecendo ensino básico e fornecendo professores, orientadores, equipamentos e materiais didáticos específicos. Entretanto, somente em 1975 as 6 (seis) Classes de Cooperação viraram novas escolas estaduais de ensino supletivo e puderam oferecer o ensino da $5^{\mathrm{a}}$ série à $8^{\mathrm{a}}$ serie (atualmente do $6^{\circ}$ ao $9^{\circ}$ ano) (RIO DE JANEIRO, 2018).

A partir de 1993, buscando descaracterizar as declarações de escolaridade do aluno, todas as escolas que existiam dentro do sistema penitenciário tiveram seus nomes alterados após a escolha de um patrono. Dez anos depois, em 2003, as Escolas passaram a se chamar Colégios ${ }^{20}$, quando foi concedida autorização para oferecer o Ensino Médio.

A Emenda Constitucional n 59 de 2009 deu o direito as pessoas jovens e adultas a demandar do Estado o Ensino Médio público e gratuito. Em 2015 essa questão foi reforçada com relação às prisões, quando a então presidenta Dilma Rousseff sancionou novas mudanças na Lei de Execução Penal. Essa nova legislação determinou também, a inclusão do sistema de educação a distância e a utilização de novas tecnologias de ensino no atendimento às pessoas privadas de liberdade.

No ano de 2007 as Unidades Escolares Prisionais foram desvinculadas da área de abrangência das Coordenadorias Regionais, através da Resolução SEEDUC nº 3528/2007 e da Resolução SEEDUC no 3539/2007, passando a ser acompanhadas e administradas por uma assessoria ligada diretamente ao Gabinete do Secretário de Estado de Educação. A partir de 2008

\footnotetext{
${ }^{20}$ Apesar dos termos "escola" e "colégio" serem considerados hoje, como sinônimos de qualquer estabelecimento ou instituição de educação, no ano de 2003 o termo "escola" foi substituído por "colégio" porque, na ocasião, se compreendia que a "escola" era uma instituição que oferecia turmas até o Ensino Fundamental; já "colégio" era uma nomenclatura utilizada para as instituições que ofereciam também o Ensino Médio.
} 
essa assessoria tornou-se a Coordenadoria Especial de Unidades Escolares Prisionais e Socioeducativas (COESP), sendo criada oficialmente através do Decreto 41.348 de 11/06/2008. ${ }^{21}$ Mais tarde, em 2010, a COESP passou a se chamar Diretoria Especial das Escolas Socioeducativas e Prisionais (DIESP), ficando subordinada à Superintendência de Gestão de Ensino da SEEDUC. O Decreto 8.897/1986, que regulamenta o sistema penal do Estado do Rio de Janeiro até os dias de hoje, traz, a partir de seu artigo 30, uma série de disposições referentes à assistência educacional nas prisões.

DECRETO Nº. 8897, DE 31 DE MARÇO DE 1986.

Regulamento do Sistema Penal do Estado do Rio de Janeiro

Da Assistência Educacional

Art. 30 - A educação, nos estabelecimentos do DESIPE, compreende a educação formal, informal e profissionalizante.

Art.31 - A educação formal dar-se-á através das escolas supletivas mantidas em convênio com a Secretaria de Estado de Educação.

Art. 32 - Todas as unidades do DESIPE são obrigadas a proporcionar ensino de primeiro grau.

Art. 33 - A educação informal visa ao enriquecimento cultural do aluno, buscando desenvolver-lhe as potencialidades nas áreas artísticas, de forma a possibilitar o surgimento e aprimoramento de vocações e o resgate de nossas raízes culturais.

Art. 34 - Os estabelecimentos do DESIPE disporão de professores de artes plásticas, teatrais, literárias, musicais e de educação física.

$\S 1^{\circ}$ - Além das atividades internas, serão incentivadas as apresentações ao mundo livre, sob a forma de exposições, representações de peças e apresentação de espetáculos.

$\S 2^{\circ}$ - Na área musical, serão incentivadas, através de aulas teóricas e práticas, a formação de bandas, conjuntos instrumentais e corais.

$\S 3^{\circ}$ - No campo literário, se incentivará o gosto pela língua escrita e o desenvolvimento da criatividade dos alunos, inclusive no atendimento à produção de peças teatrais e o exercício de atividades jornalísticas.

Art. 35 - Organizar-se-ão certames, concursos e festivais nas áreas de educação física e artística.

Art. 36 - São consideradas iniciativas prioritárias na assistência educacional:

I-organização e manutenção de bibliotecas;

II-realização de palestras e conferências;

III-exibições cinematográficas;

IV-mostras artísticas;

V- programação e realização de educação física;

VI- em cooperação com o serviço social, programação de eventos que propiciem cultura e lazer;

Art. 37 - A preparação profissional promoverá a indicação ou o aprimoramento da aptidão laboral, com acesso às técnicas especializadas.

$\S 1^{\circ}$ - Visará, de preferência, à habilitação do beneficiário para atividade compatível com sua futura necessidade, em vez de se dirigir ao atendimento da conveniência dos estabelecimentos penais.

${ }^{21}$ Plano Estadual de Educação em Prisões (2012). 
$\S 2^{\circ}$ - Respeitada a regra do parágrafo supra, os cursos profissionalizantes buscarão possibilitar o aproveitamento do benefício no trabalho produtivo intramuros.

Art. 38 - O ensino profissionalizante será desenvolvido através de convênios com órgãos federais, entidades paraestatais e particulares, ou por professores contratados pela Secretaria de Estado de Justiça e do Interior ou cedidos pela Secretaria de Estado de Educação.

Art. 39 - O artesanato será organizado de sorte a se constituir em atividade produtiva, de maneira a proporcionar efetiva fonte de renda para o beneficiário quando do retorno à liberdade.

Art. 40 - O serviço educacional fornecerá relatórios à direção dos estabelecimentos quanto ao desempenho dos alunos. (RIO DE JANEIRO, 1986, p.12)

Não obstante o emprego de expressões já superadas - educação informal, primeiro grau e equívocos conceituais - bandas, conjuntos instrumentais e corais - em um estado dotado de tamanha diversidade cultural - observa-se que o Decreto de 1986 considera práticas de Educação Popular, de Educação Social e de Educação Comunitária, como veremos a seguir.

A Resolução $\mathrm{CNE} \mathrm{n}^{\circ}$ 2/2010 corrobora as indicações do decreto carioca ao prescrever, que:

Art. 10 As atividades laborais e artístico-culturais deverão ser reconhecidas e valorizadas como elementos formativos integrados à oferta de educação, podendo ser contempladas no projeto político-pedagógico como atividades curriculares, desde que devidamente fundamentadas.

Parágrafo Único. As atividades laborais, artístico-culturais, de esporte e de lazer, previstas no caput deste artigo, deverão ser realizadas em condições e horários compatíveis com as atividades educacionais.

Art. $12 \mathrm{O}$ planejamento das ações de educação em espaços prisionais poderá contemplar, além das atividades de educação formal, propostas de educação não-formal, bem como de educação para o trabalho, inclusive na modalidade de Educação a Distância, conforme previsto em Resoluções deste Conselho sobre a EJA. (Resolução CNE nº 2/2010, grifo nosso)

É importante observar que não iremos denominar a Educação nas Prisões como "educação não-formal" pois seguimos a linha teórica que acredita que em todo o processo educativo é necessário compreender suas especificidades. Neste sentido, Silva et al. (2014) entendem que rotular a educação nas prisões como "educação não-formal" significa negar suas dimensões históricas, políticas e ideológicas, separando e distinguindo seus processos da educação formal.

O atual cenário da educação no sistema prisional do Estado do Rio de Janeiro se distancia muito dos objetivos propostos pelo Decreto 8.897/86 e pela Resolução CNE n 2/2010. Em algumas unidades prisionais, por exemplo, as atividades educativas são realizadas de forma improvisada, com pequenos grupos em uma cela. O ensino de primeiro grau (agora Ensino Fundamental I), aparentemente obrigatório conforme o artigo 32 do referido decreto, não está 
disponível em todas as unidades prisionais. Muitas vezes essas questões se dão devido à falta de apoio técnico na própria unidade prisional e por falta de recursos financeiros que venham contribuir para tal prática, conforme veremos no terceiro capítulo.

Outra situação preocupante é a formação dos professores. Segundo os estudos de Silva \& Moreira (2011) sobre a realidade do Estado de São Paulo, os cursos de formação de professores ainda não estão sensibilizados com a necessidade de se formar docentes para a atuação em espaços como as prisões. Lecionar em prisões, segundo os autores, tem sido opção apenas para os profissionais em início de carreira ou àqueles que não encontram lugar na rede regular de ensino.

É preciso analisar então, o porquê da inexistência de uma formação acadêmica específica para professores que desenvolvem suas atividades em espaços diferenciados como as prisões. A Educação de Jovens e Adultos (EJA) por si só, sofre preconceitos por fugir das regras do ensino tradicional, o que implica na organização de um currículo flexível que assegure o ingresso a qualquer tempo. Entretanto, o trabalho desenvolvido por educadores no sistema prisional se difere da forma pela qual o ensino regular é estabelecido, pois a educação prisional possui características próprias que exigem uma atenção diferenciada por parte dos professores, muitas vezes não se enquadrando no modelo tradicional da Educação de Jovens e Adultos (EJA).

Destacar as especificidades da educação nas prisões deve ser fator determinante para a formação de professores, contribuindo também, para a elaboração de indicadores de avaliação que deem conta de "apreender a multiplicidade de fatores presentes na relação de ensino e aprendizagem dentro da prisão" (Silva \& Moreira, 2011, p.97).

É possível verificar com o trabalho de Onofre (2011) que existem pequenas iniciativas na formação de educadores voltada para a atuação em Educação de Jovens e Adultos, porém, a temática da educação prisional é um assunto fora de questão nesses cursos. Segundo a autora, pelo fato da prisão apresentar necessidades advindas da trajetória escolar, questões que se vinculam à violência e ao delito e à história social e cultural, tais especificidades demonstram a complexidade do ato pedagógico, o que justifica a importância da formação de professores para esse ambiente.

Outro marco importante na história de luta pela construção de uma educação prisional que atenda aos sujeitos privados de liberdade no Estado foi a elaboração do Plano Estadual de 
Educação para a Educação Básica no Estado do Rio de Janeiro, implementado através da Lei $5.597 / 2009^{22}$.

O Plano Estadual foi elaborado pela SEEDUC/RJ à luz da lei n. ${ }^{\circ}$ 10.172/2001 que institui o Plano Nacional de Educação, e da Lei de Diretrizes e Bases da Educação n. ${ }^{\circ}$ 9394/1996. Ele possui objetivos e metas direcionadas para a ampliação e universalização do ensino nas três etapas que compõem a Educação Básica, com a qualidade que permita a continuidade de estudos para àqueles que optarem pela Educação Superior, bem como a inserção no mundo do trabalho, em condições de igualdade àqueles oriundos das redes privadas de educação (RIO DE JANEIRO, 2009, p. 30).

No ano de 2012, em atendimento às Diretrizes Nacionais para a Oferta da Educação em Estabelecimentos Penais (BRASIL, 2010) e em parceria com a Secretaria de Estado de Administração Penitenciária (SEAP), a SEEDUC/RJ elaborou o primeiro Plano Estadual de Educação em Prisões do Estado do Rio de Janeiro (PEEP/RJ) ${ }^{23}$. O PEEP (2018) estabelece como uma das meta da SEEDUC/RJ a ampliação a cada cinco anos, de pelo menos $20 \%$ da oferta de vagas da educação em todo o Sistema Prisional, garantindo acesso e permanência a todo indivíduo privado de liberdade. No entanto, como já relatamos anteriormente, em 2018 apenas 3.142 pessoas privadas de liberdade estavam envolvidas em atividades educacionais, o que correspondia a $6 \%$ da população prisional do estado.

Segundo o Plano Estadual de Educação em Prisões (2018), o sistema prisional do Estado do Rio de Janeiro conta hoje com 19 espaços educacionais, dentro de 21 unidades prisionais oferecendo a educação básica, distribuídos da seguinte forma: 19 colégios estaduais que oferecem o ensino fundamental e ensino médio presenciais, e 02 anexos de colégios estaduais do próprio sistema prisional que oferecem o ensino fundamental e ensino médio presenciais. Ao todo, 357 professores estão envolvidos em atividades de ensino nas prisões do estado. ${ }^{24}$

As unidades escolares prisionais do Estado do Rio de Janeiro estão distribuídas da seguinte forma:

22 O Plano Estadual de Educação para a Educação Básica no Estado do Rio de Janeiro está disponível em <https://seguro.mprj.mp.br/documents/112957/1453349/Plano_Estadual_Educacao.pdf >. Acesso em 06/02/2018, às 22:24h.

${ }^{23}$ Disponível no anexo A.

${ }^{24}$ Dado fornecido através de consulta pública realizada por meio do Sistema Eletrônico de Informação ao Cidadão (e-SIC-RJ). 
Tabela 5 - Unidades escolares prisionais do Estado do Rio de Janeiro (2019) ${ }^{25}$

\begin{tabular}{|l|l|l|}
\hline \multicolumn{1}{|c|}{ Unidades Escolar Prisional } & \multicolumn{1}{|c|}{ Município } & \multicolumn{1}{|c|}{ Unidade Prisional } \\
\hline CE Mário Quintana & Rio de Janeiro & Penitenciária Lemos Brito \\
\hline CE Rubem Braga & Rio de Janeiro & $\begin{array}{l}\text { Instituto Penal Benjamim de Moraes } \\
\text { Filho }\end{array}$ \\
\hline CE Anacleto de Medeiros & Rio de Janeiro & Presídio Evaristo de Moraes \\
\hline CE Henrique de Souza Filho & Rio de Janeiro & Penitenciária Vicente Piragibe \\
\hline $\begin{array}{l}\text { CE Angenor de Oliveira } \\
\text { Cartola }\end{array}$ & Rio de Janeiro & $\begin{array}{l}\text { Penitenciária Industrial Esmeraldino } \\
\text { Bandeira }\end{array}$ \\
\hline CE Roberto Burle Marx & Rio de Janeiro & Penitenciária Talavera Bruce \\
\hline CE Professor Carlos da Costa & Rio de Janeiro & Penitenciária Dr. Serrano Neves \\
\hline CE Professora Alda Lins Freire & Rio de Janeiro & Penitenciária Alfredo Tranjan \\
\hline $\begin{array}{l}\text { CE Professora Sonia Maria } \\
\text { Menezes Soares }\end{array}$ & Rio de Janeiro & Penitenciária Jonas Lopes de Carvalho \\
\hline CE José Lewgoy & Rio de Janeiro & Penitenciária Moniz Sodré \\
\hline $\begin{array}{l}\text { CE Primeiro Tenente PM } \\
\text { Hailton dos Santos }\end{array}$ & Rio de Janeiro & Presídio Nelson Hungria \\
\hline CE Padre Bruno Trombetta & Rio de Janeiro & Presídio Elizabeth Sá Rego \\
\hline $\begin{array}{l}\text { CE Escritor e Jornalista } \\
\text { Graciliano Ramos }\end{array}$ & Rio de Janeiro & Instituto Penal Plácido de Sá Carvalho \\
\hline CE Evandro João da Silva & Rio de Janeiro & Penitenciária Dr. Serrano Neves \\
\hline $\begin{array}{l}\text { CE Carlos Pereira Guimarães } \\
\text { Filho }\end{array}$ & Japeri & Presídio João Carlos da Silva \\
\hline CE Mário Lago & Rio de Janeiro & Cadeia Pública Pedro Melo da Silva \\
\hline CE Maria Montessori & Rio de Janeiro & $\begin{array}{l}\text { Penitenciária Joaquim Ferreira de } \\
\text { Souza }\end{array}$ \\
\hline CE Theodoro Sampaio & $\begin{array}{l}\text { Campos dos } \\
\text { Goytacazes }\end{array}$ & Presídio Carlos Tinoco da Fonseca \\
\hline CE Marinheiro João Cândido & Niterói & Instituto Penal Ismael Pereira Sirieiro \\
\hline & & \\
\hline
\end{tabular}

Fonte: Secretaria de Estado de Educação - SEEDUC/RJ

De acordo com as Diretrizes Nacionais para a oferta de educação para jovens e adultos em situação de privação de liberdade nos estabelecimentos penais ${ }^{26}$ estabelecidas pelo CNE em

\footnotetext{
${ }^{25}$ Dados fornecidos através de consulta pública realizada por meio do Sistema Eletrônico de Informação ao Cidadão (e-SIC-RJ).

${ }^{26}$ BRASIL. Conselho Nacional de Política Criminal e Penitenciária (Cnpcp). Resolução no 3, de 11 de março de 2009. Dispõe sobre as Diretrizes Nacionais para a Oferta de Educação nos Estabelecimentos penais. Diário Oficial da União, Brasília, Seção 1, p. 22, 25 mar. 2009. Brasília, v. 24, n. 86, p. 89-103, nov. 2011. Disponível em <http://portal.mec.gov.br/index.php?option=com_docman\&view=download\&alias=5142-rceb00210\&category_slug=maio-2010-pdf\&Itemid=30192> Acesso em: 27 mai. 2019.
} 
2010, os estados devem garantir às pessoas privadas de liberdade, condições de acesso e permanência na Educação Superior (graduação e pós-graduação), entretanto, o ensino superior não é oferecido em nenhuma das unidades prisionais do Estado do Rio de Janeiro. Desta forma, somente as pessoas privadas de liberdade em regime semiaberto conseguem ter acesso às universidades.

Em junho de 2017 a Secretaria de Estado de Administração Penitenciária (SEAP) e a Secretaria de Estado de Ciência, Tecnologia e Desenvolvimento Social (SECTDS), por intermédio da Fundação Centro de Ciências e Educação Superior a Distância do Estado do Rio do Janeiro (CECIERJ), assinaram um Termo de Cooperação Técnica com a $3^{\text {a }}$ Promotoria de Justiça de Tutela Coletiva de Proteção à Educação da capital para implantação de projeto de educação superior à distância no sistema prisional do Estado. O projeto visa à construção de uma edificação no Complexo de Gericinó que funcionará como um polo do Centro de Educação Superior a Distância do Estado do Rio de Janeiro (CEDERJ) ${ }^{27}$, onde os internos poderão cursar graduação dentro do Complexo. O interno que estiver cumprindo sua pena fora do Complexo Penitenciário de Gericinó poderá pedir transferência para unidades prisionais desse complexo para estudar. Todos serão selecionados com notas que tirarem no Exame Nacional do Ensino Médio (ENEM) para vagas que serão disputadas somente entre os internos.

No ano de 2018, com o objetivo de coletar dados documentais para esta tese e de cobrar o andamento deste projeto, realizamos um pedido de solicitação de informações à Fundação CECIERJ através do Sistema Eletrônico de Informação ao Cidadão (e-SIC-RJ), onde obtemos a seguinte resposta:

Protocolo $n^{\circ} 3188$ :

Prezada Taíza,

O projeto do polo no sistema prisional é antigo, mas até o momento não foi implementado. Nos últimos 2 anos o projeto deslanchou com a assinatura do convênio entre a SECTDS, a SEAP, a Fundação CECIERJ e o MP. Foi assinado um Termo de Cooperação em junho de 2017, quando foi apresentado o projeto para implantação do polo, com as adaptações que seriam necessárias, especialmente aquelas ligadas à segurança. Nesse período, ficou acertado que a SEAP seria responsável pela construção do prédio físico onde seria instalado o polo dentro do Complexo de Gericinó. A diretoria de infraestrutura da fundação CECIERJ fez as plantas do prédio e mapeamos todo o material que seria

${ }^{27}$ O Consórcio Cederj é formado por sete Instituições públicas de Ensino Superior no Estado do Rio de Janeiro (CEFET, UENF, UERJ, UFF, UFRJ, UFRRJ E A UNIRIO) em parceria com a Universidade Aberta do Brasil (UAB) e com a Secretaria de Estado de Ciência, Tecnologia e Desenvolvimento Social do Estado do Rio de Janeiro, por intermédio da Fundação Cecierj e tem como objetivo a oferta de cursos de graduação a distância, na modalidade semipresencial para todo o Estado. Fonte: <http://cederj.edu.br/fundacao/>. Acesso em 03 mai. 2019. 
necessário. A fundação CECIERJ também solicitou às Universidades do Consórcio que aderissem ao projeto e conseguiu dois cursos para o novo polo, o curso de Geografia da UERJ e o curso de Pedagogia da UENF, como cursos iniciais. No momento, a SECTDS, a SEAP, a Fundação CECIERJ e o MP estão procurando maneiras de conseguir os recursos necessários para o início das obras. Entretanto, a crise financeira que se abateu sobre o estado do RJ atrasou mais um pouco a realização deste importante projeto.

Att,

Marilvia Dansa de Alencar

Diretora Acadêmica

Vice-Presidente de EaD

Reconhecemos a importância da inclusão das universidades públicas no processo de educação nas prisões do Estado do Rio de Janeiro, entretanto, nos valemos por lembrar da necessidade de, primeiramente, se garantir o acesso à educação básica para todos.

A tese de doutorado de Carolina Bessa Ferreira de Oliveira intitulada A educação nas prisões brasileiras: a responsabilidade da universidade pública, apresenta a experiência da Argentina com a educação superior em prisões e as probabilidades de implementação desta modalidade de ensino nas prisões do estado de São Paulo.

Oliveira (2017), ao identificar universidades públicas, seus campi, núcleos e centros de pesquisa presentes no estado de São Paulo, e a distribuição espacial das unidades prisionais, produziu um mapa de possibilidades de encontros entre a prisão e a universidade.

Problematiza-se, com isso, a responsabilidade da universidade pública como instituição propositora e implementadora de políticas públicas de educação para todos, incluindo-se as pessoas em situação de privação de liberdade em dado território. (OLIVEIRA, C, 2017, p. 178)

Também podem servir como referência neste sentido, as experiências positivas a respeito da inserção da universidade nas prisões brasileiras, como é o caso da iniciativa da Universidade Estadual da Paraíba (UEPB) que implementou um campus avançado no Presídio do Serrotão e das atividades de cultura e extensão desenvolvidas pelo Grupo de Diálogo Universidade-CárcereComunidade (GDUCC) da Faculdade de Direito da Universidade de São Paulo. ${ }^{28}$

Existe no âmbito do Estado do Rio de Janeiro, uma parceria entre a SEEDUC, a SEAP e a Universidade do Estado do Rio de Janeiro (UERJ) que propicia a aplicação de exame de vestibular aos internos, entretanto, acreditamos que a UERJ, enquanto instituição pública de ensino superior,

\footnotetext{
${ }^{28}$ Sobre essas experiências, ver o estudo de Oliveira, C. (2017).
} 
possa ampliar o leque de possibilidades dentro do sistema prisional do Estado, inclusive cobrando a garantia de acesso e permanência primeiramente à educação básica.

É notório que a oferta de educação no sistema prisional do Estado do Rio de Janeiro convive com problemas crônicos de diferentes ordens, como, por exemplo, as estruturas precárias (ou a falta delas), o descaso do poder público e o preconceito da sociedade. São inúmeros os aspectos que dificultam a compreensão e a implementação de processos educacionais mais conectados a uma visão emancipadora de educação que a considere como um direito humano.

O Brasil, no decorrer dos últimos anos, tem construído um legado de leis, normas e documentos que visam garantir os direitos dos cidadãos privados de liberdade, entretanto, muitas dessas propostas legais não têm sido aplicadas pelos Estados. Neste sentido, vimos a necessidade de destacar e analisar o arcabouço legal que norteia as práticas educativas nas prisões brasileiras, que será o objeto de estudo do próximo capítulo. 


\section{A GARANTIA dO DIREITO À EDUCAÇÃO NAS PRISÕES DO BRASIL E DO ESTADO DO RIO DE JANEIRO}

Pretende-se neste capítulo, identificar as normativas internacionais, nacionais e estaduais sobre o direito à educação nas prisões do Brasil e do Estado do Rio de Janeiro. Desta forma, serão analisadas as Diretrizes Nacionais para a Oferta da Educação em Estabelecimentos Penais (BRASIL, 2010) e sua relação com os compromissos ratificados pelo Estado brasileiro quando da adesão à tratados e convenções internacionais sobre o tratamento dado às pessoas privadas de liberdade. Pretende-se ainda, investigar de forma aprofundada, o processo de implantação das diretrizes nacionais no contexto prisional do Estado do Rio de Janeiro, considerando às categorias enunciadas nos três eixos do Projeto Educando para a Liberdade (UNESCO, 2006).

Com o decorrer dos anos foi possível observar mudanças significativas nos marcos legais que se relacionam com a temática da educação nas prisões brasileiras. É importante destacar de forma introdutória, que a educação aparece pela primeira vez na Constituição Imperial de 1824 interligada à cidadania

Art. 179. A inviolabilidade dos Direitos Civis, e Politicos dos Cidadãos Brazileiros, que tem por base a liberdade, a segurança individual, e a propriedade, é garantida pela Constituição do Imperio, pela maneira seguinte.

XXXII. A Instrucção primaria, e gratuita a todos os Cidadãos.

XXXIII. Collegios, e Universidades, aonde serão ensinados os elementos das Sciencias, Bellas Letras, e Artes. (BRASIL, 1824, p.17)

Mais de um século depois, em 1948, a Declaração Universal dos Direitos Humanos das Nações Unidas, em seu artigo 26, considera a educação como um direito fundamental que deve ser assegurado a todos.

\section{ARTIGO 26}

1.Toda a pessoa tem direito à educação. A educação deve ser gratuita, pelo menos a correspondente ao ensino elementar fundamental. $\mathrm{O}$ ensino elementar é obrigatório. $\mathrm{O}$ ensino técnico e profissional deve ser generalizado; acesso aos estudos superiores deve estar aberto a todos em plena igualdade, em função do seu mérito.

2.A educação deve visar à plena expansão da personalidade humana e ao reforço dos direitos do homem e das liberdades fundamentais e deve favorecer a compreensão, a tolerância e a amizade entre todas as nações e todos os grupos raciais ou religiosos, bem como o desenvolvimento das atividades das Nações Unidas para a manutenção da paz.

3.Aos pais pertence a prioridade do direito de escolher o gênero de educação a dar aos filhos. (ONU, 1948) 
No ano de 1955 foi realizado em Genebra o Primeiro Congresso das Nações Unidas sobre a Prevenção do Crime e o Tratamento dos Delinquentes, que adotou as Regras Mínimas para o Tratamento dos Reclusos. Tais regras foram aprovadas pelo Conselho Econômico e Social das Nações Unidas através das suas Resoluções 663 C (XXIV), de 31 de julho de 1957 e 2076 (LXII), de 13 de maio de $1977 .^{29}$

As Regras Mínimas para o Tratamento dos Reclusos procuram estabelecer os princípios de uma boa organização penitenciária, entretanto, a ONU reconhece que, devido à grande variedade das condições legais, sociais, econômicas e geográficas do mundo, nem todas as regras podem ser aplicadas de forma indistinta e permanentemente em todos os lugares. Devem, em todo o caso, servir como estímulo de esforços constantes para ultrapassar dificuldades práticas na sua aplicação.

Considerado um dos documentos mais relevantes no meio internacional, as Regras Mínimas para o Tratamento dos Reclusos destacam, no item 77, a importância da educação nas prisões. Segundo o texto, a educação de analfabetos e jovens reclusos deve estar integrada ao sistema educacional do país, para que seja possível, depois da sua libertação, continuar, sem dificuldades, a sua formação.

Em relação à legislação nacional, no ano de 1984 foi aprovada a Lei 7.210, conhecida como Lei de Execução Penal (LEP), com vistas a "efetivar as disposições de sentença ou decisão criminal e proporcionar condições para a harmônica integração social do condenado e do internado", conforme a redação do seu artigo primeiro. Uma das propostas da LEP é a valorização dos direitos humanos das pessoas privadas de liberdade, proporcionando um tratamento individualizado através da garantia de assistência material, à saúde, jurídica, educacional, social e religiosa.

A educação é tratada na LEP na Seção V - Da Assistência Educacional, nos artigos 17 a 21 A. Tais artigos asseguram a instrução escolar e a formação profissional do preso e do internado, tornando obrigatórios, inicialmente, o ensino fundamental e o ensino profissionalizante nas prisões, integrados ao sistema estadual e municipal de ensino.

Em seu artigo 21 a LEP estabelece que cada estabelecimento penal tenha uma biblioteca "para uso de todas as categorias de reclusos, provida de livros instrutivos, recreativos e didáticos". A alteração realizada em 2015 também prevê a apuração, através de censo penitenciário, do nível

\footnotetext{
29 Disponível em <https://www2.camara.leg.br/atividade-legislativa/comissoes/comissoespermanentes/cdhm/comite-brasileiro-de-direitos-humanos-e-politica-externa/RegMinTratRec.html>. Acesso em 05 set. 2019.
} 
de escolaridade das pessoas presas, a existência de cursos nos níveis fundamental e médio e o número de alunos atendidos, a implementação de cursos profissionais em nível de iniciação ou aperfeiçoamento técnico e o número pessoas privadas de liberdade atendidas, a existência de bibliotecas e as condições de seu acervo, além de outros dados relevantes para o aprimoramento educacional nas prisões.

No artigo 83 a LEP prevê ainda, que nos estabelecimentos penais contenham "áreas e serviços destinados a dar assistência, educação, trabalho, recreação e prática esportiva" e também que "haverá instalação destinada a estágio de estudantes universitários", entretanto, não garante em nenhum de seus artigos o acesso ao ensino superior por parte dos internos.

Em 2011 a Lei 12.433 alterou a Lei de Execução Penal estabelecendo a remição da pena em razão do estudo em seu artigo 126. Assim, para cada 12(doze) horas de frequência escolar (atividade de ensino fundamental, médio, inclusive profissionalizante, ou superior, ou ainda de requalificação profissional) divididas, no mínimo, em 3 (três) dias, é remido 1(um) dia de pena.

Posteriormente à aprovação da LEP foi promulgada a Constituição da República Federativa do Brasil em 1988, como fundamentos do Estado Democrático de Direito e após um período de 20 anos de ditadura militar no país que perpassou pelos anos 1964 a 1985. A CF/88 é considerada um importante marco jurídico na garantia dos direitos do cidadão, principalmente por estabelecer os direitos e deveres civis, políticos e sociais, garantindo a cidadania. Em seu artigo $6^{\circ}$, a educação ficou reconhecida como direito social de todos, inclusive dos sujeitos privados de liberdade. O artigo 205 da CF/88 também ampliou a responsabilidade do Estado e da família em relação ao dever de garantir a educação, especificando que sua promoção e seu incentivo devem ocorrer com a colaboração da sociedade, visando ao pleno desenvolvimento da pessoa, seu preparo para o exercício da cidadania e sua qualificação para o trabalho.

Mais tarde, em 1996, surge o Programa Nacional de Direitos Humanos, elaborado a partir de ampla consulta à sociedade realizada pelo Núcleo de Estudos da Violência da Universidade de São Paulo. O PNDH é considerado um importante instrumento para a construção de uma política nacional que abarque os sujeitos privados de liberdade. Foi o primeiro programa para proteção e promoção de direitos humanos da América Latina e o terceiro no mundo, segundo os estudos de Neto \& Pinheiro (1997).

O Programa reflete e fortalece uma mudança na concepção de direitos humanos, já partilhada anteriormente por organizações de direitos humanos, mas pela primeira vez 
adotada e defendida pelo governo brasileiro na história republicana, segundo a qual os direitos humanos não são apenas os direitos civis e políticos, mas também os direitos econômicos, sociais e culturais, tanto dos indivíduos quanto da coletividade. Os direitos humanos deixam de ser limitados aos direitos definidos em constituições e leis nacionais e passam a abranger os direitos definidos em tratados internacionais. (NETO \& PINHEIRO, 1997, p. 123)

O Programa Nacional de Direitos Humanos passou por três atualizações, sendo a última delas feita através do Decreto $\mathrm{n}^{\circ} 7.037$, de 21 de dezembro de 2009, publicado durante o governo do presidente Luiz Inácio Lula da Silva.

O PNDH-3 estabeleceu seis eixos orientadores: I- Interação democrática entre Estado e sociedade civil; II- Desenvolvimento e Direitos Humanos; III- Universalizar direitos em um contexto de desigualdades; IV- Segurança Pública, Acesso à Justiça e Combate à Violência; VEducação e Cultura em Direitos Humanos, VI- Direito à Memória e à Verdade.

O Eixo Orientador IV apresenta como diretriz de número dezesseis a "modernização da política de execução penal, priorizando a aplicação de penas e medidas alternativas à privação de liberdade e melhoria do sistema penitenciário" (BRASIL, 2009, p. 02). No anexo do PNDH-3 é elencado como objetivo estratégico da referida diretriz a "reestruturação do sistema penitenciário", considerando a reforma da Lei de Execução Penal que ocorreu mais tarde, no governo de Dilma Rousseff, através da Lei n ${ }^{\circ} 13.163$, de 2015.

Desde a década de 1980, em meio à diversas lutas políticas e sociais, a Educação de Jovens e Adultos perpassa por um processo de constante reconstrução. Segundo estudos de Carvalho (2014), a EJA deixou de ser considerada uma educação "não escolarizada" e tornou-se uma modalidade da educação básica em um contexto de rupturas e mudanças onde foi aprovada a reformulação no ano de 1996, da Lei de Diretrizes e Bases da Educação Nacional (LDB - Lei n ${ }^{\circ}$ 9.394/96).

Cury (1997) explica sobre as dificuldades ocorridas no processo de construção da LDB, que levou cerca de 8 anos e teve a iniciativa do poder legislativo em vez do executivo. Destaca que uma lei de educação nacional deve considerar a realidade de excludência e de discriminação brasileira, sendo efetiva no que se refere à universalização do direito à educação. Por este motivo, numa perspectiva histórica, a elaboração de leis relacionadas à educação possuem maior eficiência quando feitas de forma democrática, levando em conta as opiniões dos diversos sujeitos envolvidos, como educadores e a própria sociedade. 
A Lei de Diretrizes e Bases da Educação Nacional estabelece em seu artigo $1^{\text {o }}$ que a educação deve abranger os processos formativos que se desenvolvem na vida familiar, na convivência humana, no trabalho, nas instituições de ensino e pesquisa, nos movimentos sociais e organizações da sociedade civil e nas manifestações culturais, vinculando-se ao mundo do trabalho e à prática social.

A LDB reservou o Título III para tratar “do direito à educação e do dever de educar”, onde aparece a expressão "educação básica" como um conceito novo, além de ser um direito e também uma forma de organizar a educação nacional, conforme explica Cury (2008).

Como conceito, a educação básica veio esclarecer e administrar um conjunto de realidades novas trazidas pela busca de um espaço público novo. Como um princípio conceitual, genérico e abstrato, a educação básica ajuda a organizar o real existente em novas bases e administrá-lo por meio de uma ação política consequente. (CURY, 2008, p. 294)

A educação básica, presente no artigo $4^{\circ}$ da LDB, é colocada como um direito de todos e um dever do Estado em garanti-la com qualidade. É inegável também que a LDB, neste sentido, possibilitou uma mudança significativa dentro de um Estado Democrático de Direito e em um país que, historicamente, negou para determinados sujeitos, o direito ao conhecimento através da escola.

Outra questão importante que diz respeito ao Título III da LDB está relacionada à oferta de educação para jovens e adultos, com características e modalidades adequadas às suas necessidades e disponibilidades. Apesar da LDB versar sobre a EJA tanto no artigo $4^{\circ}$ quanto na Seção V do Título V destacando sua integração à educação básica, em momento algum contempla as especificidades da educação nas prisões. Por este motivo, a temática é tratada no âmbito da modalidade de EJA.

Em seu artigo $5^{\circ}$ a LDB reconhece que o acesso à educação básica é um direito público subjetivo de qualquer cidadão.

Art. $5^{\circ}$ - O acesso à educação básica obrigatória é direito público subjetivo, podendo qualquer cidadão, grupo de cidadãos, associação comunitária, organização sindical, entidade de classe ou outra legalmente constituída e, ainda, o Ministério Público, acionar o poder público para exigi-lo. (BRASIL, 1996, p. 03) 
Neste sentido, a LDB ratifica o direito constitucional à educação, que transcende a condição de estar preso ou não, entretanto, mesmo com isto, o acesso à educação ainda não se efetivou nas prisões do Brasil, visto os dados apresentados no capítulo anterior sobre o quantitativo de pessoas privadas de liberdade envolvidas em atividades educacionais.

A LDB também estabeleceu a "Organização da Educação Nacional”, definindo as responsabilidades entre as três esferas de Governo. Desta forma, os municípios ficaram responsáveis por oferecer, prioritariamente, o ensino fundamental; aos estados, o ensino médio; e à União, prestar assistência técnica e financeira a ambos.

No ano seguinte a aprovação da LDB, na V Conferência Internacional sobre Educação de Adultos (CONFINTEA) realizada na Alemanha, na cidade de Hamburgo, foi aprovada a Declaração de Hamburgo sobre Educação de Adultos que garantiu avanços no tocante ao direito à educação nas prisões em nível internacional. Paiva, Machado \& Ireland (2007) destacam que a Declaração de Hamburgo é o eixo fundamental que antecede e norteia outros documentos que se constituem numa proposta de acompanhamento e busca de efetividade nas ações assumidas pelos governos.

A temática da educação básica também foi discutida na V Confintea e está presente no item 9 da Declaração de Hamburgo. A Declaração destaca que a educação básica não é apenas um direito mas também um dever e uma responsabilidade para com os outros e com toda a sociedade, sendo fundamental que o seu reconhecimento ao longo da vida seja acompanhando de medidas que garantam as condições necessárias para o exercício desse direito.

Surge através da Declaração de Hamburgo um novo conceito de educação de adultos que se alicerça nos desafios às práticas existentes que devem ser encarados com enfoque dentro do contexto da educação continuada.

Na ocasião da V Confintea também foi formulada uma Agenda para o Futuro da Educação de Adultos onde ficaram definidos os compromissos em favor do desenvolvimento da educação de adultos propostos pela Declaração de Hamburgo. O Tema VIII - A educação para todos os adultos: os direitos e aspirações dos diferentes grupos - reconheceu no item 47, o direito à educação nas prisões.

47 - Reconhecer o direito dos detentos à aprendizagem:

a) informando os presos sobre as oportunidades de ensino e de formação existentes em diversos níveis, e permitindo--lhes o acesso a elas; 
b) elaborando e pondo em marcha, nas prisões, amplos programas de ensino, com a participação dos detentos, a fim de responder às suas necessidades e aspirações em matéria de educação;

c) facilitando a ação das organizações não governamentais, dos professores e dos outros agentes educativos nas prisões, permitindo, assim, aos detentos o acesso às instituições educativas, estimulando as iniciativas que tenham por fim conectar os cursos dados na prisão com os oferecidos fora dela. (PAIVA, MACHADO \& IRELAND, 2007, p. 64)

A Declaração de Hamburgo e a Agenda para o Futuro estabelecidas pela V Confintea, segundo Paiva, Machado \& Ireland (2007), não receberam a atenção que merecem nas principais reformas educacionais e em iniciativas internacionais, revelando uma regressão no campo da educação de adultos. Em contrapartida, os autores acreditam que, a partir da V Confintea, se estabeleceu uma nova consciência global que passou a considerar outros tipos de educação e de aprendizagem como possíveis.

Outro marco importante na legislação brasileira ocorreu no ano de 2000, com a aprovação das Diretrizes Curriculares Nacionais para a Educação de Jovens e Adultos através da Resolução CNE/CEB n n 01/2000. O documento reconhece o direito à educação escolar para jovens e adultos, observando a formulação de propostas pedagógicas que considerem as especificidades desta modalidade.

O Plano Nacional de Educação (PNE) foi instituído no ano de 2001, pela Lei 10.172/2001, elencando 295 metas a serem cumpridas pela educação brasileira nos 10 anos seguintes (2001 2010). O PNE de 2001 resultou de ações da sociedade com o objetivo de garantir o cumprimento do artigo 214 da Constituição Federal de 1988.

\footnotetext{
Art. 214. A lei estabelecerá o plano nacional de educação, de duração plurianual, visando à articulação e ao desenvolvimento do ensino em seus diversos níveis e à integração das ações do poder público que conduzam à:

I - erradicação do analfabetismo;

II - universalização do atendimento escolar;

III - melhoria da qualidade do ensino;

IV - formação para o trabalho;

V - promoção humanística, científica e tecnológica do País.

(BRASIL, 1988)
}

A LDB também estabelece em seu artigo 87, $\S 1^{\circ}$, que a União deveria, no prazo de um ano, encaminhar ao Congresso Nacional o PNE com diretrizes e metas para os dez anos seguintes, em sintonia com a Declaração Mundial sobre Educação para Todos. Com base nisto, Dourado 
(2010) destaca que o governo do então presidente Fernando Henrique Cardoso, através do Ministério da Educação, efetivou lógicas de gestão visando implementar uma reforma na educação nacional que se constituía pela adoção de políticas com foco principal no ensino fundamental e em instrumentos que visavam à construção de um sistema de avaliação da educação.

Na análise de Dourado (2010), as diretrizes do PNE de 2001 revelam uma falta de organização interna no Plano, na medida em que as metas são reiteradas e até mesmo superpostas, ou não apresentam a devida articulação no que diz respeito à concepções, financiamento e gestão. Segundo o autor, mesmo apresentando grandes desafios para a melhoria da educação nacional, o PNE ficou marcado pela ausência de mecanismos concretos de financiamento, dando margem para a interpenetração entre as esferas pública e privada e, com isso, abrindo espaço para novas formas de privatização da educação, principalmente da educação superior.

Especificamente sobre a temática da educação prisional, o PNE de 2001 contemplou nos seus objetivos a implementação em todas as unidades prisionais, dos programas de EJA de níveis fundamental e médio, além da formação profissional, fornecendo o material didático adequado e visando também, a oferta de programas de educação a distância.

5. Estabelecer programa, nacional de fornecimento, pelo Ministério da Educação, de material didático-pedagógico, adequado à clientela, para os cursos em nível de ensino fundamental para jovens e adultos, de forma a incentivar a generalização das iniciativas mencionadas na meta anterior.

(...)

14. Expandir a oferta de programas de educação a distância na modalidade de educação de jovens e adultos, incentivando seu aproveitamento nos cursos presenciais.

(...)

17. Implantar, em todas as unidades prisionais e nos estabelecimentos que atendam adolescentes e jovens infratores, programas de educação de jovens e adultos de nível fundamental e médio, assim como de formação profissional, contemplando para esta clientela as metas $\mathrm{n}^{\circ} 5 \mathrm{e} \mathrm{n}^{\mathrm{o}} 14$. (BRASIL, 2001, p. 42-43)

Apesar do PNE de 2001 não mencionar formas de como garantir a educação nos estabelecimentos penais, segundo Carvalho (2014), ocorreu uma evolução em relação ao texto da LDB no sentido de não omitir a educação prisional no documento. ${ }^{30}$

\footnotetext{
${ }^{30}$ No ano de 2014, a então Presidenta Dilma Rousseff, aprovou a Lei 13.005/2014 que estabeleceu um novo PNE para os próximos 10 anos (entre 2014 e 2024), apresentando em suas metas 8, 9 e 10, questões relativas à elevação da escolaridade entre jovens e adultos. Nesta tese, utilizaremos como referência o PNE de 2001, pois Plano Estadual de Educação e o Plano Estadual de Educação em Prisões, ambos em vigor, ainda não foram atualizados considerando o PNE de 2014.
} 
Foi implementado no ano de 2003, o Programa Brasil Alfabetizado, sob responsabilidade da Secretaria de Educação Continuada, Alfabetização, Diversidade e Inclusão (SECADI), do Ministério da Educação. O Programa tem como objetivo promover a superação do analfabetismo entre jovens com 15 anos ou mais, adultos e idosos e contribuir para a universalização do ensino fundamental no Brasil. Sua concepção reconhece a educação como direito humano e a oferta pública da alfabetização como porta de entrada para a educação e a escolarização das pessoas ao longo de toda a vida. ${ }^{31}$

Em 2005 a Resolução n 23/2005 do MEC, ao estabelecer os critérios e os procedimentos para transferência dos recursos financeiros do Programa Brasil Alfabetizado aos estados, ao Distrito Federal e aos municípios, incluiu a população prisional dentre o público de atendimento do Programa.

\subsection{O Projeto Educando para a Liberdade}

Nos anos de 2005 e 2006 foi desenvolvido o Projeto Educando para a Liberdade: trajetória, debates e proposições de um projeto para a educação nas prisões brasileiras (UNESCO, 2006), fruto de uma parceria entre os ministérios da Educação e da Justiça e da Representação da UNESCO no Brasil, com apoio do governo do Japão. O Projeto se constituiu em um dos marcos mais importantes da história da educação nas prisões do Brasil, servindo como referência para os estados e para a sociedade, além de reafirmar os compromissos do governo com a educação como um direito de todos.

No início da construção do Projeto Educando para a Liberdade (UNESCO, 2006), os órgãos ministeriais identificaram que a construção de uma política pública para o atendimento educacional nas prisões demandaria uma canalização de investimentos objetivando provocar o impacto desejado junto às realidades estaduais. Diante disto, o MEC levou a proposta à UNESCO que, com recursos do governo do Japão, incluiu a questão num projeto já existente, voltado a fortalecer os programas de alfabetização do país, como resultado dos compromissos assumidos pelo governo federal para o cumprimento das metas estabelecidas no Marco de Dacar de Educação para Todos (2000) e no âmbito da Década das Nações Unidas para a Alfabetização (2003-2012). ${ }^{32}$

\footnotetext{
${ }^{31}$ Disponível em: <http://portal.mec.gov.br>. Acesso em 28/09/2019, às 11:00h.

${ }^{32}$ Fonte: <http://www.educadores.diaadia.pr.gov.br/arquivos/File/eja_prisao/educando_liberdade_ unesco.pdf>. Acesso em 28/09/2019, às 15:44h.
} 
O Projeto Educando para a Liberdade (UNESCO, 2006), além de atender as deliberações da V Confintea, possibilitou que a oferta da educação nas prisões fizesse parte de questões mais amplas como o cumprimento dos direitos humanos fundamentais (direito à educação) e a construção da cultura de paz, estabelecida como meta da UNESCO no Congresso Internacional sobre a Paz nas Mentes dos Homens, realizado em 1989.

Conforme relatório da UNESCO (2006), as atividades do Projeto se iniciaram no final do primeiro mandato do então presidente Luiz Inácio Lula da Silva, em julho de 2005. Foram realizadas visitas de diagnóstico em alguns estados que serviram para reafirmar as impressões das instituições envolvidas quanto aos problemas que seriam encontrados, além de ajudarem na definição das dimensões de operação e na metodologia a ser adotada.

A partir dos relatórios das visitas aos estados foram elaboradas três dimensões.

A primeira dimensão era relacionada à mobilização e à articulação das pastas da Educação e da Administração Penitenciária nos estados para uma oferta coordenada. Sem que essa relação estivesse estabelecida em bases muito sólidas, a tendência era de que um sistema sempre buscasse colocar sobre os ombros do outro a responsabilidade pelo nãoatendimento. Por isso, era necessário criar ou fortalecer um canal de interlocução entre essas instituições e seus principais dirigentes, para o qual a atuação do governo federal e da própria UNESCO constituía-se estratégica.

A segunda dimensão abrangia as identidades e as práticas dos profissionais que ajudam a organizar o atendimento educacional no interior dos estabelecimentos penais. Por um lado, realçava a necessidade de formação diferenciada dos professores, para que soubessem lidar com as características do público e do ambiente em que trabalham. Por outro lado, denunciava como os desencontros entre segurança e assistência só atuavam em prejuízo dos direitos da população prisional. Além disso, ainda destacava a necessidade de valorização dos mais diversos segmentos da execução penal, diluindo-se a imagem precária com que aparecem perante a sociedade e os próprios presos.

A terceira dimensão, por fim, compreendia os aspectos de ordem pedagógica. Embora motivada por uma realidade bastante particular (as prisões), ela se mostrava tributária de outras discussões igualmente bem assentadas no campo da educação de jovens e adultos e da educação popular. Como assegurar que a educação nas prisões ajude a promover a autonomia e a emancipação dos sujeitos envolvidos? (UNESCO, 2006, pp. 18-19)

Diante destas dimensões, optou-se pela organização da primeira Oficina de Trabalho realizada em Brasília com o objetivo de fazer com que as equipes da administração penitenciária e da educação de jovens e adultos dos estados refletissem sobre a sua própria condição e iniciar o desenho de proposições para a melhoria do atendimento educacional nas prisões. ${ }^{33}$

\footnotetext{
${ }^{33}$ Fonte: <http://www.educadores.diaadia.pr.gov.br/arquivos/File/eja_prisao/educando_liberdade_ unesco.pdf>. Acesso em 28/09/2019, às 15:44h.
} 
Ficou acordado na Oficina que os estados participantes realizariam seminários no sentido de serem mediadores da proposta. Mais do que isso, conforme destaca Carvalho (2014, p. 119), os seminários deram início a "um movimento de discussão e reflexão de estratégias de fortalecimento de oferta de educação básica nos estabelecimentos penais do país".

Ainda em 2005 foi realizado no Estado do Rio de Janeiro, o I Seminário de Articulação Nacional e Construção de Diretrizes para a Educação no Sistema Penitenciário. Em 2006 os eventos ocorreram em Goiás, Rio Grande do Sul, Paraíba e Ceará, nos quais se registrou ainda a participação das equipes do Tocantins, Mato Grosso, Mato Grosso do Sul, Paraná, Santa Catarina, Pernambuco, Rio Grande do Norte, Piauí e Maranhão. ${ }^{34}$

Os seminários se constituíram em espaços de discussões e debates coletivos entre educadores, gestores, agentes penitenciários, pesquisadores e especialistas, entretanto, não contaram com a participação da população prisional. O resultado final de todo esse processo foi o debate proposto através do I Seminário Nacional pela Educação nas Prisões, realizado em Brasília entre os dias 12 e 14 de julho de 2006, com a participação de representantes de todos os estados.

Com base no documento "Seminário Nacional pela Educação nas Prisões: Significados e Proposições" ${ }^{\prime 35}$ publicado pela UNESCO após o evento, os estados e o governo federal puderam rediscutir suas dinâmicas de financiamento e avançar na consolidação das diretrizes mais adequadas para a educação nas prisões. O Seminário também serviu para reafirmar duas convicções do Projeto Educando para a Liberdade (UNESCO, 2006): primeiro, de que educação é um direito de todos; depois, de que a concepção e implementação de políticas públicas, visando ao atendimento especial de segmentos da população estrutural e historicamente fragilizados, constituem um dos modos mais significativos pelos quais o Estado e a Sociedade podem renovar o compromisso para com a realização desse direito e a democratização de toda a sociedade. ${ }^{36}$

O Seminário Nacional dividiu as propostas do Projeto Educando para a Liberdade (UNESCO, 2006) em três eixos que se complementam entre si. O primeiro eixo, "Gestão, articulação e mobilização", tem o objetivo de propor estímulos e subsídios para a atuação da União, dos estados e da sociedade civil, no que diz respeito à formulação, execução e monitoramento de políticas públicas para a educação nas prisões. Neste sentido, foram elencados 21 itens como

\footnotetext{
${ }^{34}$ Fonte: <http://www.educadores.diaadia.pr.gov.br/arquivos/File/eja_prisao/educando_liberdade_ unesco.pdf>. Acesso em 28/09/2019, às 15:44h.

${ }^{35}$ Disponível em: <https://unesdoc.unesco.org/ark:/48223/pf0000147583>. Acesso em 30/09/2019, às 08:50h.

${ }^{36}$ Fonte: <https://unesdoc.unesco.org/ark:/48223/pf0000147583>. Acesso em 30/09/2019, às 08:50h.
} 
objetivos a serem seguidos pelos estados e pelo governo federal, visando a garantia de uma educação de qualidade nas prisões brasileiras.

1. O Governo Federal, por meio dos Ministérios da Educação e da Justiça, figure como o responsável pelo fomento e indução de políticas públicas de Estado no domínio da Educação nas Prisões, estabelecendo as parcerias necessárias junto aos Estados e Municípios;

2. A oferta de educação no sistema penitenciário seja fruto de uma articulação entre o órgão responsável pela Administração Penitenciária e a Secretaria de Educação que atue junto ao sistema local, cabendo a ambas a responsabilidade pela gestão e pela coordenação desta oferta, sob a inspiração de Diretrizes Nacionais;

3. A articulação implique na disponibilização do material pedagógico da modalidade de EJA para as Escolas que atuam no Sistema Penitenciário, como insumo para a elaboração de projetos pedagógicos adequados ao público em questão;

4. O trabalho articulado encontre as devidas oportunidades de financiamento junto às Pastas Estaduais e aos órgãos Ministeriais, especialmente com a inclusão dos alunos matriculados no Censo Escolar;

5. A gestão se mantenha aberta a parcerias com outras áreas de governo, universidades e organizações da sociedade civil, sob a orientação de Diretrizes Nacionais;

6. Os educadores do sistema pertençam, preferencialmente, aos quadros da Secretaria de Educação, selecionados por concursos públicos e com remuneração acrescida de vantagens pecuniárias condizentes com as especificidades do cargo;

7. A gestão propicie espaços físicos adequados às práticas educativas (p. ex.: salas de aula, bibliotecas, laboratórios etc.), além de adquirir os equipamentos e materiais necessários, evitando improvisos e mudanças constantes;

8. A construção de espaços adequados para a oferta de educação, bem como de esporte e cultura, seja proporcional à população atendida em cada unidade;

9. As autoridades responsáveis pela gestão transformem a Escola num espaço de fato integrado às rotinas da unidade prisional e da execução penal, com a inclusão de suas atividades no plano de segurança adotado;

10. Seja realizado um diagnóstico da vida escolar dos apenados logo no seu ingresso ao sistema, com vistas a obter dados para a elaboração de uma proposta educacional que atenda às demandas e circunstâncias de cada um;

11. Seja garantido o atendimento diferenciado para presos(as) do regime fechado, semiaberto, aberto, presos provisórios e em liberdade condicional e aqueles submetidos à medida de segurança independente de avaliação meritocrática;

12. O atendimento contemple a diversidade, atentando-se para as questões de inclusão, acessibilidade, gênero, etnia, credo, idade e outras correlatas;

13. Os responsáveis pela oferta elaborem estratégias para a garantia de continuidade de estudos para os egressos, articulando-as com entidades que atuam no apoio dos mesmos - tais como patronatos, conselhos e fundações de apoio ao egresso e organizações da sociedade civil;

14. A remição pela educação seja garantida como um direito, de forma paritária com a remição concedida ao trabalho e cumulativa quando envolver a realização paralela das duas atividades;

15. O trabalho prisional seja tomado como elemento de formação e não de exploração de mão-de-obra, garantida a sua oferta em horário e condições compatíveis com as da oferta de estudo;

16. Além de compatível, o trabalho prisional (e todas as demais atividades orientadas à de reintegração social nas Prisões) se torne efetivamente integrado à educação;

17. Seja garantida uma certificação não-estigmatizante para as atividades cursadas pelos educandos (sejam eles cursos regulares de ensino fundamental e médio, atividades não- 
formais, cursos profissionalizantes, etc.), de maneira a conciliar a legislação e o interesse dos envolvidos;

18. Exista uma política de incentivo ao livro e à leitura nas unidades, com implantação de bibliotecas e com programas que atendam não somente aos alunos matriculados, mas a todos os integrantes da comunidade prisional;

19. Seja elaborada uma cartilha incentivando os apenados à participação nos programas educacionais, bem como informações relativas a remição pelo estudo;

20. Os documentos e materiais produzidos pelos Ministérios da Educação e da Justiça e/ou pelas Secretarias de Estado de Educação e de Administração Penitenciária, que possam interessar aos educadores e educandos do Sistema, sejam disponibilizados e socializados, visando ao estreitamento da relação entre os níveis de execução e de gestão da Educação nas Prisões;

21. Sejam promovidos encontros regionais e nacionais sobre a Educação nas Prisões envolvendo todos os atores relevantes, em especial Diretores de Unidades Prisionais e do Setor de Ensino, tendo como um dos itens de pauta a troca de experiências. (UNESCO, 2006, pp. 36-38)

\section{O segundo eixo, "Formação e valorização dos profissionais envolvidos na oferta", pretende}

contribuir para a qualidade da formação e para as boas condições de trabalho de gestores, educadores, agentes penitenciários e operadores da execução penal. Desta forma, foram elencados

os seguintes itens norteadores do segundo eixo:

22. Ao ingressar no cotidiano do sistema prisional, o professor passe por um processo de formação, promovido pela pasta responsável pela Administração Penitenciária em parceria com a da Educação, no qual a educação nas prisões seja tematizada segundo os marcos da política penitenciária nacional.

23. A formação continuada dos profissionais que atuam no sistema penitenciário ocorra de maneira integrada, envolvendo diferentes áreas, como trabalho, saúde, educação, esportes, cultura, segurança, assistência psicossocial e demais áreas de interesse, de modo a contribuir para a melhor compreensão do tratamento penal e aprimoramento das diferentes funções de cada segmento.

24. No âmbito de seus projetos político-pedagógicos, as escolas de formação de profissionais penitenciários atuem de forma integrada e coordenada para formação continuada de todos os profissionais envolvidos e aprimoramento nas condições de oferta da educação no sistema penitenciário. Nos estados em que elas não existem, sejam implementadas, conforme Resolução ${ }^{\circ} 04$ do Conselho Nacional de Política Criminal e Penitenciária.

25. As instituições de ensino superior e os centros de pesquisa sejam considerados parceiros potenciais no processo de formação dos profissionais do sistema, na execução de projetos de formação e na organização e disponibilização de acervos bibliográficos.

26. A formação dos servidores penitenciários contemple na sua proposta pedagógica a dimensão educativa do trabalho desses profissionais na relação com o preso.

27. Os atores estaduais estimulem a criação de espaços de debate, formação, reflexão e discussão como fóruns e redes que reflitam sobre o papel da educação nas prisões.

28. Os cursos superiores de graduação em Pedagogia e as demais licenciaturas incluam nos seus currículos a formação para a EJA e, nela, a educação prisional.

29. Os educandos e educadores recebam apoio de profissionais técnicos (psicólogos, terapeutas, fonoaudiólogos etc.) para o constante aprimoramento da relação de ensinoaprendizagem.

30. A pessoa presa, com perfil e formação adequados, possa atuar como monitor no processo educativo, recebendo formação continuada condizente com suas práticas pedagógicas, com direito à remição e remuneração. (UNESCO, 2006, pp. 39-40) 
O terceiro eixo, por sua vez, compreende os "aspectos pedagógicos", e tem o objetivo de garantir a qualidade da oferta da educação nas prisões, com base nos fundamentos conceituais e legais da educação de jovens e adultos, bem como os paradigmas da educação popular, calcada nos princípios da autonomia e da emancipação dos sujeitos do processo educativo.

31. Venha a ser criado um regimento escolar próprio para o atendimento nos estabelecimentos de ensino do sistema prisional, no intuito de preservar a unidade filosófica, políticopedagógico estrutural e funcional das práticas de educação nas prisões. 32. Seja elaborado em cada estado os seus projetos pedagógicos próprios para a educação nas prisões, contemplando as diferentes dimensões da educação (escolarização, cultura, esporte e formação profissional), considerando a realidade do sistema prisional para a proposição das metodologias.

33. Seja estimulada a produção de material didático específico para a educação no sistema penitenciário, para complementar os recursos de EJA disponibilizados pela gestão local. 34. Seja elaborado um currículo próprio para a educação nas prisões que considere o tempo e o espaço dos sujeitos da EJA inseridos nesse contexto e que enfrente os desafios que ele propõe em termos da sua reintegração social.

35. Seja elaborada essa proposta curricular a partir de um Grupo de Trabalho que ouça os sujeitos do processo educativo nas prisões (educadores, educandos, gestores do sistema prisional, agentes penitenciários e pesquisadores de EJA e do sistema prisional).

36. Seja incluída na educação de jovens e adultos no sistema penitenciário a formação para o mundo do trabalho, entendido como um lócus para a construção da autonomia do sujeito e de desenvolvimento de suas capacidades profissionais, intelectuais, físicas, culturais e sociais.

37. Sejam os familiares dos presos e a comunidade em geral estimulados, sempre que possível, a acompanhar e a participar de atividades educacionais que contribuam para o processo de reintegração social.

38. Sejam ampliadas as possibilidades de educação a distância em seus diferentes níveis, resguardando-se deste atendimento o ensino fundamental.

39. Sejam ampliadas as possibilidades de uso de tecnologias nas salas de aula de unidades prisionais, visando ao enriquecimento da relação de ensino-aprendizagem.

40. Seja garantida a autonomia do professor na avaliação do aluno em todo o processo de ensino aprendizagem. (UNESCO, 2006, pp. 40-41)

O Projeto Educando para a Liberdade (UNESCO, 2006) provocou, através do Seminário Nacional, um debate público sobre a educação nas prisões brasileiras, colocando em discussão a necessidade da construção coletiva de uma política nacional que compreenda a educação como direito de todos. Neste sentido, o relatório final do Seminário Nacional pela Educação nas Prisões, incluído no Projeto Educando para a Liberdade (UNESCO, 2006), apresentou propostas para a elaboração de diretrizes nacionais que tratassem sobre a educação nas prisões brasileiras. 


\subsection{As Diretrizes Nacionais para a Oferta de Educação nos Estabelecimentos Penais}

No ano de 2009, o Conselho Nacional de Política Criminal e Penitenciária (CNPCP) publicou a Resolução $n^{\circ}$ 03/2009 37 estabelecendo as Diretrizes Nacionais para a Oferta de Educação nos estabelecimentos penais.

A Resolução reconhece o Projeto Educando para a Liberdade (UNESCO, 2006) como referência fundamental para o desenvolvimento de uma política pública de educação no contexto prisional, feita de forma integrada e cooperativa, além de representar um novo paradigma de ação, a ser desenvolvido no âmbito das prisões.

Merece destaque o artigo $3^{\circ}$, I, da Resolução no 03/2009 do CNPCP, que determina que a oferta de educação no contexto prisional deve atender aos eixos pactuados quando da realização do Seminário Nacional pela Educação nas Prisões, quais sejam: a) gestão, articulação e mobilização; b) formação e valorização dos profissionais envolvidos na oferta de educação na prisão; e c) aspectos pedagógicos. As Diretrizes trazem como anexo o capítulo "Seminário Nacional pela Educação nas Prisões: Significados e Proposições”, do Projeto Educando para a Liberdade (UNESCO, 2006), que especifica cada eixo proposto.

A Resolução nº 03/2009 do CNPCP prevê a realização de parcerias da educação com outras áreas de governo, universidades e organizações da sociedade civil com o objetivo de formular, executar, monitorar e avaliar as políticas públicas de estímulo à educação nas prisões. No artigo $9^{\text {a }}$ menciona que os profissionais envolvidos (educadores, gestores, técnicos e agentes penitenciários) devem ter acesso a programas de formação que auxiliem na compreensão das especificidades e relevância das ações de educação nos estabelecimentos penais, bem como da dimensão educativa do trabalho.

\subsection{As Diretrizes Nacionais para a oferta de educação para jovens e adultos em situação de privação de liberdade nos estabelecimentos penais}

Os debates iniciados em 2005 no I Seminário Nacional de Educação nas Prisões, a posterior aprovação da Resolução nº 03/2009 do CNPCP, que dispõe sobre as Diretrizes Nacionais para a oferta de educação nos estabelecimentos penais, o Plano Nacional de Educação (PNE) e o Projeto

37 Disponível em: <http://portal.mec.gov.br/index.php?option=com_docman\&view=download\&alias= 10028resolucao-3-2009-secadi\&category_slug=fevereiro-2012-pdf\&Itemid=30192>. Acesso em 05/10/2019, às 10:45h. 
Educando para a Liberdade (UNESCO, 2006) foram marcos importantes e que resultaram na proposta de implementação das Diretrizes Nacionais para a oferta de educação para jovens e adultos em situação de privação de liberdade nos estabelecimentos penais.

Também destaca-se como um dos fatores fundamentais para a elaboração das Diretrizes, a realização em 2009, da VI Confintea no Brasil, na cidade de Belém, que resultou no documento denominado "Marco de Ação de Belém”. O Marco é constituído por recomendações apresentadas na Conferência com o objetivo de serem implementadas nas políticas públicas de educação de jovens e adultos dos países participantes. A VI Confintea reconheceu que o papel da aprendizagem ao longo da vida é fundamental para resolver questões globais e desafios educacionais, sendo um princípio organizador de todas as formas de educação, se constituindo como abrangente e parte integrante da visão de uma sociedade do conhecimento.

Em maio de 2009 o Ministério da Educação (MEC) encaminhou ao Conselho Nacional de Educação (CNE) proposta de minuta de Resolução que tratava sobre as Diretrizes Nacionais para a oferta de educação para jovens e adultos em situação de privação de liberdade nos estabelecimentos penais brasileiros. A proposta juntou as sugestões de diferentes atores envolvidos na questão da educação nas prisões, acumuladas como resultado de debates em diversas reuniões e seminários realizados sobre o assunto no país.

Na ocasião, a Câmara de Educação Básica (CEB) do CNE designou como relator do processo o conselheiro Adeum Hilário Sauer, que realizou uma reunião de trabalho e uma audiência pública com a participação de representantes governamentais e da sociedade civil, para aprofundar a discussão em torno do Parecer e das diversas sugestões de Resolução apresentadas pelas entidades envolvidas no assunto. ${ }^{38}$

O relator especifica que, para a composição do documento, procurou observar o questões como: a) a distinção entre o que é de competência de "diretriz" e de "política" educacional; b) a compatibilidade e coerência das sugestões com o conjunto do documento; c) os limites de uma Resolução do CNE, ao tratar da oferta de educação em estabelecimentos penais, para não adentrar a competência do CNPCP; d) consonância com a legislação e as normas em vigor. ${ }^{39}$

\footnotetext{
${ }^{38}$ BRASIL. Relatório sobre as Diretrizes Nacionais para a oferta de educação para jovens e adultos em situação de privação de liberdade nos estabelecimentos penais. Relator: Adeum Hilário Sauer. Conselho Nacional de Educação: Brasília, 2010. p. $02 . \quad$ Disponível em: <http://portal.mec.gov.br/index.php?option $=$ com_docman\&view=download\&alias=4445-pceb004-10\&category_slug=abril-2010-pdf \&Itemid=30192>. Acesso em 08 out. 2019.

${ }^{39}$ Ibid. p. 02.
} 
O documento leva em conta somente as atribuições do CNE, dialogando com as Diretrizes Nacionais para a oferta de educação nos estabelecimentos penais do CNPCP. Neste sentido, o objetivo das Diretrizes é apresentar elementos para a definição de uma política macro que possa orientar particularidades regionais e/ou institucionais sobre a oferta da educação nas prisões.

A "diretriz" não tem o objetivo de "resolver" questões administrativas e nem questões de ordem da execução penal (de competência do CNPCP e não do CNE), mas sim questões de ordem da política de educação para o sistema penitenciário que sejam atribuição do órgão normativo da educação nacional. (BRASIL, 2010a, p. 03)

Sobre essa questão, Carvalho (2014, p. 122), ao analisar o relatório, considera que o relator Adeum Sauer, "ciente da complexidade e do jogo de forças que envolvem as relações e as políticas públicas no espaço prisional, tenta 'suavizar' os pontos que o próprio parecer não contempla", transferindo para as autoridades locais de cada estado, a responsabilidade de elaboração de documentos a partir das diretrizes.

No que diz respeito ao texto das Diretrizes, este orienta em seu artigo $2^{\circ}$, que as ações de educação nas prisões devem se basear na legislação educacional vigente no país, na Lei de Execução Penal, nos tratados internacionais firmados pelo Brasil no âmbito das políticas de direitos humanos e privação de liberdade. Esclarece que tais ações devem sempre atender às especificidades dos diferentes níveis e modalidades de educação e ensino e são extensivas aos presos provisórios, condenados, egressos do sistema prisional e àqueles que cumprem medidas de segurança.

As Diretrizes elencam oito orientações para a oferta de educação para jovens e adultos em estabelecimentos penais. São elas:

I - é atribuição do órgão responsável pela educação nos Estados e no Distrito Federal (Secretaria de Educação ou órgão equivalente) e deverá ser realizada em articulação com os órgãos responsáveis pela sua administração penitenciária, exceto nas penitenciárias federais, cujos programas educacionais estarão sob a responsabilidade do Ministério da Educação em articulação com o Ministério da Justiça, que poderá celebrar convênios com Estados, Distrito Federal e Municípios;

II - será financiada com as fontes de recursos públicos vinculados à manutenção e desenvolvimento do ensino, entre as quais o Fundo de Manutenção e Desenvolvimento da Educação Básica e de Valorização dos Profissionais da Educação (FUNDEB), destinados à modalidade de Educação de Jovens e Adultos e, de forma complementar, com outras fontes estaduais e federais;

III - estará associada às ações complementares de cultura, esporte, inclusão digital, educação profissional, fomento à leitura e a programas de implantação, recuperação e 
manutenção de bibliotecas destinadas ao atendimento à população privada de liberdade, inclusive as ações de valorização dos profissionais que trabalham nesses espaços;

IV - promoverá o envolvimento da comunidade e dos familiares dos indivíduos em situação de privação de liberdade e preverá atendimento diferenciado de acordo com as especificidades de cada medida e/ou regime prisional, considerando as necessidades de inclusão e acessibilidade, bem como as peculiaridades de gênero, raça e etnia, credo, idade e condição social da população atendida;

$\mathrm{V}$ - poderá ser realizada mediante vinculação a unidades educacionais e a programas que funcionam fora dos estabelecimentos penais;

VI - desenvolverá políticas de elevação de escolaridade associada à qualificação profissional, articulando-as, também, de maneira intersetorial, a políticas e programas destinados a jovens e adultos;

VII - contemplará o atendimento em todos os turnos;

VIII - será organizada de modo a atender às peculiaridades de tempo, espaço e rotatividade da população carcerária levando em consideração a flexibilidade prevista no art. 23 da Lei ${ }^{\circ}$ 9.394/96 (LDB). (BRASIL, 2010b, p. 02)

Sobre a oferta da educação nas prisões, as Diretrizes deixam a cargo das Secretarias de Educação ou órgãos equivalentes dos Estados, a articulação com a administração penitenciária, sendo de responsabilidade do Ministério da Educação e do Ministério da Justiça somente os programas educacionais realizados nas penitenciárias federais.

Os recursos para a oferta da educação nas prisões, conforme as Diretrizes, serão aqueles vinculados à manutenção e ao desenvolvimento do ensino, incluindo os do Fundo de Manutenção e Desenvolvimento da Educação Básica e de Valorização dos Profissionais da Educação (FUNDEB), além de outras fontes complementares de cunhos estaduais e federais.

As Diretrizes estabelecem que as ações educacionais nas prisões estejam associada às ações complementares de cultura, esporte, inclusão digital, educação profissional, fomento à leitura e a programas de implantação, recuperação e manutenção de bibliotecas destinadas ao atendimento à população prisional, inclusive as ações de valorização dos profissionais que trabalham nesses espaços. Considera a prisão como um espaço amplo e dotado diversidades ao propor a promoção do envolvimento da comunidade e dos familiares dos indivíduos privados de liberdade, prevendo o atendimento diferenciado que leve em conta as necessidades de inclusão e acessibilidade, bem como as peculiaridades de gênero, raça e etnia, credo, idade e condição social.

A oferta da educação nas prisões, conforme as Diretrizes, poderá ser realizada através de vínculos com unidades educacionais e programas que funcionem fora das unidades prisionais, como é o caso, no Rio de Janeiro, das parcerias feitas com o Serviço Nacional de Aprendizagem Industrial (SENAI), o Serviço Nacional de Aprendizagem Comercial (SENAC) e o Centro Federal de Educação Tecnológica (CEFET). 
As Diretrizes orientam que os sistemas educacionais desenvolvam políticas de elevação de escolaridade associada à qualificação profissional, articulando-as, também, de maneira intersetorial, a políticas e programas destinados a jovens e adultos, como é o exemplo do programa Brasil Alfabetizado. Também prevê que as atividades educacionais possam contemplar o atendimento em todos os turnos. ${ }^{40}$

Segundo as Diretrizes, a oferta da educação nas prisões será organizada de modo a atender às peculiaridades de tempo, espaço e rotatividade da população carcerária. Responsabiliza os órgãos de educação dos Estados e no Distrito Federal à institucionalizar mecanismos de informação sobre a educação em espaços de privação de liberdade, tornando público, por meio de relatório anual, a situação e as ações realizadas em cada estabelecimento penal, além de promover programas e projetos de fomento à pesquisa, de produção de documentos e publicações e a organização de campanhas sobre o valor da educação; e implementar estratégias de divulgação das ações de educação para os internos.

$\mathrm{O}$ artigo $5^{\circ}$ das Diretrizes diz que os Estados, o Distrito Federal e a União deverão incentivar a promoção de novas estratégias pedagógicas, produção de materiais didáticos e a implementação de novas metodologias e tecnologias educacionais, assim como de programas educativos na modalidade Educação a Distância (EAD), a serem empregados no âmbito das escolas do sistema prisional.

Sobre a implementação da Educação a Distância nas prisões, Pardo (2011) relata a experiência pioneira do Centro Universitário de Maringá que iniciou um projeto na Penitenciária Estadual de Maringá, firmando parceria para ofertar os cursos de formação superior em nível de Tecnologia, Bacharelado e Licenciatura aos detentos desse complexo prisional. Na Colônia Penal Agrícola localizada no estado do Paraná também utiliza a EAD como uma modalidade auxiliadora da Educação de Jovens e Adultos (EJA), com o objetivo de combater a alta rotatividade dos alunos (KANNO, 2013).

As Diretrizes estabelecem que a gestão da educação nas prisões deverá promover parcerias com diferentes esferas e áreas de governo, bem como com universidades, instituições de Educação Profissional e organizações da sociedade civil, com vistas à formulação, execução, monitoramento e avaliação de políticas públicas de Educação de Jovens e Adultos em situação de privação de

\footnotetext{
${ }^{40}$ Nos estabelecimentos penais do Estado do Rio de Janeiro não existe o ensino noturno devido à proibição por parte da SEAP.
} 
liberdade, complementando assim, a política implementada pelos órgãos responsáveis pela educação da União, dos Estados e do Distrito Federal.

As Diretrizes do CNE, assim como as Diretrizes Nacionais para a Oferta de Educação nos Estabelecimentos Penais do CNPCP imputam a reponsabilidade às autoridades responsáveis pela política de execução penal nos Estados e Distrito Federal, de propiciar espaços físicos adequados às atividades educacionais, esportivas, culturais, de formação profissional e de lazer.

Conforme as Diretrizes, também serão contempladas pelas instituições e programas educacionais nas prisões, as ações, projetos e programas governamentais destinados a EJA, incluindo o provimento de materiais didáticos e escolares, apoio pedagógico, alimentação e saúde dos estudantes.

Outro fator importante que consta nas Diretrizes é a oferta de Educação Profissional nos estabelecimentos penais, onde, em seu artigo $9^{\circ}$ é especificado que esta modalidade deverá seguir as Diretrizes Curriculares Nacionais definidas pelo CNE, inclusive com relação ao estágio profissional supervisionado concebido como ato educativo. As Diretrizes, neste sentido, vai ao encontro da meta da EJA prevista no Plano Nacional de Educação que busca implementar nas prisões programas de formação profissional.

As atividades laborais e artístico-culturais deverão ser reconhecidas e valorizadas como elementos formativos integrados à oferta de educação, entretanto, as Diretrizes deixam claro que tais atividades deverão ser realizadas em condições e horários compatíveis com as atividades educacionais, de modo que os internos tenham acesso a ambas atividades.

Sobre os educadores, gestores e técnicos que atuam nos estabelecimentos penais, as Diretrizes estabelecem que estes deverão ter acesso a programas de formação inicial e continuada que levem em consideração as especificidades da política de execução penal. Os docentes, por sua vez, devem ser profissionais do magistério devidamente habilitados e com remuneração condizente com as especificidades da função. Sobre esse aspecto, Carvalho (2014) atenta para a carência de formação específica para os profissionais que atuam nas prisões, além da valorização das condições de trabalho e de suas remunerações.

(...) é recorrente nos vários sistemas de ensino que ofertam a modalidade, o fato de que grande parte dos professores não recebe formação específica e adequada para trabalhar com jovens e adultos e, muito menos, jovens e adultos presos. (...) O exercício do magistério exige profissionais devidamente qualificados e com remuneração e condições de trabalho adequadas. (CARVALHO, 2014, p. 126) 
As pessoas privadas de liberdade, desde que possua perfil adequado e receba preparação especial, poderão atuar em apoio ao profissional da educação, auxiliando-o no processo educativo e não em sua substituição. Com isso as Diretrizes regulamentaram uma prática já existente nas prisões de alguns estados, como é o caso do Rio de Janeiro. As pessoas que exercem tais funções são chamadas em "educadores presos" ou de "monitores".

No artigo 12 as Diretrizes tratam do planejamento das ações de educação em espaços prisionais, sendo estes possíveis de contemplar, além das atividades de educação formal, propostas de educação não escolar, bem como de educação para o trabalho, inclusive na modalidade de Educação a Distância, recomendando que as ações desenvolvidas sigam um calendário unificado e comum a todos os estabelecimentos.

Ainda no artigo 21, $\S 2^{\circ}$, as Diretrizes estabelecem que devem ser garantidas as condições de acesso e permanência na Educação Superior (graduação e pós-graduação), a partir da participação em exames de estudantes que demandam esse nível de ensino, respeitadas as normas vigentes e as características e possibilidades dos regimes de cumprimento de pena previstas na LEP. Essa prática, no entanto, se constitui como frágil, diante da existência de inúmeros entraves no processo de garantia do direito à educação nas prisões, conforme explicitado pelo estudo de Oliveira (2017b).

(...) a oferta de educação em prisões se apresenta como complexa, por envolver diferentes instituições e organizações, uma necessária articulação entre gestores e profissionais, além das características próprias da prisão, pautadas na ordem e no controle.

Ainda que legalmente a educação em prisões tenha amparo e garantia no Brasil, verificamos uma prática fragilizada, seja pelo hiperencarceramento e ausência de condições para o exercício desse direito no espaço prisional, seja pela não priorização institucional e política desse público como sujeito de direito à educação. (OLIVEIRA, 2017b, p. 90)

Um experiência positiva a respeito da inserção da universidade nas prisões é a iniciativa da Universidade Estadual da Paraíba (UEPB) que implementou um campus avançado no Presídio do Serrotão, localizado no município de Campina Grande. ${ }^{41}$

A Diretrizes estabelecem no artigo 13, que os planos de educação da União, dos Estados, do Distrito Federal e Municípios deverão incluir objetivos e metas de educação em espaços de privação de liberdade que atendam as especificidades dos regimes penais previstos no Plano

\footnotetext{
${ }^{41}$ Sobre a experiência do campus avançado da Universidade Estadual da Paraíba, ver os estudos de Oliveira (2017 b).
} 
Nacional de Educação. Todavia, não existe a obrigatoriedade de se definir prazos para que tais objetivos e metas sejam de fato cumpridos.

A implementação e a fiscalização das Diretrizes, no âmbito estadual, ficou a cargo dos Conselhos de Educação dos Estados e do Distrito Federal, ao passo que, nas penitenciárias federais, esta responsabilidade compete ao Conselho Nacional de Educação ou, mediante acordo e delegação, aos Conselhos de Educação dos Estados onde se localizam tais estabelecimentos penais.

As Diretrizes Nacionais para a Oferta de Educação nos Estabelecimentos Penais, em síntese, representam um grande avanço no âmbito da educação nas prisões no Brasil. Para Oliveira (2017b),

\begin{abstract}
A publicação das Diretrizes, por parte do CNE, ao final desse processo, induziu a uma maior visibilidade do tema, qualificação das ações de educação básica nas prisões, desdobramentos no que diz respeito à remição de pena por estudos e leitura e à maior regulamentação e organização por parte dos Estados. (OLIVEIRA, 2017b, p.156)
\end{abstract}

As Diretrizes, além de garantirem o direito à educação para todos, contempla inúmeras manifestações dos atores envolvidos, decorrentes de espaços de discussão e de debates acerca da educação nas prisões, se constituindo como um documento democrático e cheio de expectativas a serem alcançadas.

\title{
2.4 O Plano Estadual de Educação do Rio de Janeiro
}

Logo após a publicação das Diretrizes Nacionais para a Oferta de Educação nos estabelecimentos penais o Estado do Rio de Janeiro instituiu o seu Plano Estadual de Educação, através da Lei Estadual no 5597, de 18 de dezembro de 2009 ${ }^{42}$. Isso se deu porque, no ano de 2007 , a Comissão de Educação a Assembleia Legislativa do Estado do Rio de Janeiro (ALERJ) fez uma representação junto ao Ministério Público Estadual, para que o Plano fosse apresentado.

Desta forma, a SEEDUC foi responsável por iniciar um processo interno de constituição de uma comissão organizadora que se desdobrou em comissões temáticas, cada uma delas responsável por elaborar os diagnósticos, as diretrizes, os objetivos e as metas referentes às diferentes modalidades de ensino, para compor o texto da proposta de Minuta do Plano Estadual de Educação, à luz da Lei n. ${ }^{\circ}$ 10.172/2001 que institui o Plano Nacional de Educação, da Lei de

\footnotetext{
${ }^{42}$ Disponível em: < https://seguro.mprj.mp.br/documents/112957/1453349/Plano_Estadual_Educacao.pdf >. Acesso em 05/10/2019, às 18:28h.
} 
Diretrizes e Bases da Educação n. ${ }^{\circ}$ 9.394/1996 e da Lei n..$^{\circ}$ 4.528/2005, que estabelece as diretrizes para a organização do Sistema de Ensino do Estado do Rio de Janeiro. ${ }^{43}$

O Plano Estadual de Educação possui objetivos e metas direcionadas para a ampliação e para a universalização do ensino nas três etapas que compõem a Educação Básica, com a qualidade que permita a continuidade de estudos para àqueles que optarem pela Educação Superior, bem como a inserção no mundo do trabalho, em condições de igualdade àqueles oriundos das redes privadas de educação.

O PEE/RJ traz no item 1.10, a temática da Educação Prisional. Destaca, de forma introdutória, que o Estado do Rio de Janeiro é pioneiro na oferta de educação nas prisões pois, desde o ano de 1967, por meio de um convênio entre a Secretaria de Estado de Educação e a Secretaria de Justiça, oferece educação aos privados de liberdade. Enfatiza também que, no ano de 2000, a remissão de pena pelo estudo foi concedida pela Vara de Execuções Penais, pelo Ministério Público e pelo Conselho Penitenciário do Estado do Rio de Janeiro. Sobre esse aspecto, Julião (2003) afirma que a decisão pela remissão por estudo foi fruto de um amplo debate.

O Rio de Janeiro, seguindo a experiência do Rio Grande do Sul, por iniciativa do Ministério Público e do Conselho Penitenciário do Estado do Rio de Janeiro, iniciou uma série de discussões com a Vara de Execuções Penais e com a Secretaria de Estado de Justiça, órgãos responsáveis pela execução e administração da política de execução penal, estimulando a criação de instrumentos para o acompanhamento e avaliação da participação dos internos nas ações educacionais oferecidas pelas unidades penais, que culminou, no ano de 2000, com o acordo que permite a remição através da educação. (JULIÃO, 2003, p. 37)

Apesar de o Estado do Rio de Janeiro ter concedido a remissão de pena pelo estudo antes da Lei n ${ }^{\circ}$ 12.433/2011 que tratou da temática, o Plano Estadual de Educação, para tentar justificar o baixo número de pessoas privadas de liberdade matriculadas nas escolas localizadas nas prisões, responsabiliza a carga horária de estudo, comparando com a remissão por trabalho.

A cada 18 horas de estudo, reduz-se um dia de pena, enquanto a remissão por trabalho, prevista no art. 126 da Lei de Execução Penal, equivale à redução de três dias de trabalho por um dia de pena. Vale ressaltar que a carga horária de trabalho dos internos é de, no mínimo, 6 horas e, no máximo, oito horas, enquanto que, na escola, permanecem por três horas diárias. Como na escola a carga horária é inferior a do trabalho, os internos que optam pelo estudo levam seis dias para remir um, o que acaba os desmotivando e, consequentemente, afastando os apenados do espaço escolar, uma vez que a remissão

43 Fonte: <https://seguro.mprj.mp.br/documents/112957/1453349/Plano_Estadual_Educacao.pdf>. Acesso em 05/10/2019, às 18:28h. 
assume grande importância na vida desses sujeitos, já que é uma forma de alcançar a liberdade o mais breve possível. (RIO DE JANEIRO, 2009, p. 28, grifo nosso)

No trecho destacado é possível perceber que os internos devem optar pela remissão através do estudo ou através do trabalho, apesar da legislação admitir a chamada remição cumulativa, ou seja, possibilitando cumular-se a remição por trabalho e por estudo, conforme o artigo $126, \S 3^{\circ}$, da LEP.

No que diz respeito à formação e a ocupação profissional dos internos, o PEE/RJ destaca que esta é uma responsabilidade da Fundação Santa $\mathrm{Cabrini}^{44}$, órgão estadual vinculado à Secretaria de Administração Penitenciária. A Fundação foi criada em setembro de 1977 para gerir e promover o trabalho remunerado nas prisões do Estado do Rio de Janeiro, entretanto, somente em 1997, passou a implementar cursos com recursos garantidos pelo Ministério do Trabalho.

$\mathrm{O}$ PEE/RJ reconhece que, apesar da obrigatoriedade do ensino nas prisões, não existem escolas em todas as unidades prisionais do estado. Demonstra também, a importância de levar em conta as especificidades dos educandos privados de liberdade, conforme a LDB e as Diretrizes Curriculares Nacionais, considerando a educação como um direito de todos, mesmo diante da perda do direito de ir e vir.

O Plano Estadual de Educação vigente foi sancionado em 2009 e, até hoje, não houve atualizações durante sua vigência. Nos dias 30 e 31 de agosto e 01 de setembro de 2019 foi realizado o III Congresso Estadual de Educação que estabeleceu em seu documento final, recomendações para um novo plano de educação no âmbito do Estado do Rio de Janeiro. A proposta foi encaminhada para elaboração de projeto de lei e posterior análise e aprovação do Poder Legislativo Estadual. ${ }^{45}$

\subsection{O Plano Estadual de Educação em Prisões do Rio de Janeiro}

Em 2011 o Decreto 7.626/11 institui o Plano Estratégico de Educação no âmbito do Sistema Prisional. ${ }^{46}$ Um dos objetivos do PEESP, previsto em seu artigo $4^{\circ}$, é de incentivar a elaboração de planos estaduais de educação para o sistema prisional, abrangendo metas e

\footnotetext{
${ }^{44}$ Saiba mais em: <https://santacabrini.rj.gov.br/>

${ }^{45}$ Informação recebida através de consulta pública protocolada com o ${ }^{\circ} 7109$, pelo Serviço Eletrônico de Informações ao Cidadão (E-SIC).

46 Disponível em: <https://presrepublica.jusbrasil.com.br/legislacao/1030066/decreto-7626-11>. Acesso em 07/10/2019, às 15:33h.
} 
estratégias de formação educacional da população carcerária e dos profissionais envolvidos em sua implementação.

Neste sentido, no ano de 2012, o Estado do Rio de Janeiro elaborou o seu primeiro Plano Estadual de Educação em Prisões (PEEP/RJ), também em atendimento às Diretrizes Nacionais para a Oferta de Educação nos Estabelecimentos Penais. O PEEP/RJ teve como principal meta o desenvolvimento e a implantação nas unidades escolares que se encontram nos espaços prisionais, de uma educação de qualidade, perpassando pela readequação do trabalho realizado e a valorização do profissional alocado nessas Unidades. ${ }^{47}$

Participaram da elaboração do Plano Estadual de Educação em Prisões do Estado do Rio de Janeiro Diretores das Unidades Escolares, Diretores das Unidades Prisionais, coordenadores pedagógicos, professores regentes, agentes penitenciários e alunos, além de atores externos, como representantes da Universidade do Estado do Rio de Janeiro (UERJ), representantes da Associação dos Educadores dos Privados de Liberdade do Estado do Rio de Janeiro (AEPLIERJ) ${ }^{48}$ e representantes do Conselho Estadual de Educação do Rio de Janeiro ${ }^{49}$.

Após a elaboração do PEEP/RJ em 2012, o documento foi enviado para o Ministério da Educação (MEC) que fez a devolutiva em 2014 para a Secretaria de Estado de Educação do Rio de Janeiro (SEEDUC), sugerindo alguns ajustes a serem definidos no ano de 2015.

O PEEP/RJ teve sua última reformulação no ano de 2018, após consulta pública realizada para esta tese, que solicitou a versão atualizada do Plano. Conforme especificado no próprio documento, foi feita somente a atualização dos dados, sendo respeitado o conceito elaborado pelo grupo de 2012. Desta forma, analisaremos nesta seção, a versão reformulada de 2018.

A construção do PEEP/RJ se iniciou com uma reunião com todos os diretores das unidades escolares para conscientização da necessidade da elaboração de um Plano Estadual de Educação em Prisões. Em um segundo momento, os atores envolvidos se reuniram para debater sobre seis eixos orientadores sugeridos pela DIESP/SEEDUC que deveriam nortear as discussões e originar uma tese-guia para cada Unidade Escolar para a elaboração final do Plano. Os eixos norteadores

\footnotetext{
${ }^{47}$ RIO DE JANEIRO. Plano Estadual de Educação em Prisões. Secretaria do Estado de Educação: Rio de Janeiro: 2018. p.06.

${ }^{48}$ Segundo informações obtidas na pesquisa de campo desta tese, a AEPLIERJ não está mais em funcionamento.

${ }^{49}$ RIO DE JANEIRO, 2018. p.06.
} 
se constituíram em: 1) Diagnóstico; 2) Objetivos, Metas e Estratégias; 3) Diretrizes; 4) Ações; 5) Segurança; 6) Legislações ainda necessárias para garantir a qualidade na educação prisional. ${ }^{50}$

Também foi realizada a eleição de cinco delegados de cada Unidade Escolar e um encontro com dois representantes de cada unidade Escolar e o Diretor da Unidade Prisional, para elaborar um documento norteador final para servir de base para o PEEP/RJ. Após a entrega da tese-guia de cada unidade escolar, foi realizado um Workshop para a elaboração e a finalização do PEEP/RJ.

O texto do PEEP/RJ se inicia apresentando uma justificativa para a sua elaboração. Para isso, apresenta alguns dados a respeito do analfabetismo no Brasil, advindos da Pesquisa Nacional por Amostra de Domicílio (PNAD) feita em 2013 pelo Instituto Brasileiro de Geografia e Estatística (IBGE). Diante de 13,4 milhões de brasileiros analfabetos e cerca de 17,8\% da população em situação de analfabetismo funcional, o PEEP/RJ avalia esses números como preocupantes, principalmente porque a eles estão associados outros fatores que configuram não só um quadro de exclusão social e econômica, mas, principalmente, porque representa a constatação de que muitos brasileiros sequer têm seus direitos fundamentais atendidos. Alerta que o quadro se agrava quando a referência passa a ser o perfil do segmento das pessoas encarceradas. ${ }^{51}$

Para superar a questão do analfabetismo nas prisões, o Estado do Rio de Janeiro aderiu ao Programa Brasil Alfabetizado ${ }^{52}$. O PEEP/RJ explica que o Programa propicia o aumento da escolarização de jovens e adultos, promovendo o acesso à educação como direito de todos em qualquer momento da vida. No ano de 2018 foram atendidos 198 alunos em 20 turmas do Programa, entretanto, o estado ainda possui 603 pessoas privadas de liberdade analfabetas e 96 que apenas sabem assinar, conforme dados apresentados pelo próprio PEEP/RJ.

\footnotetext{
${ }^{50}$ Ibid, pp.08-09.

${ }^{51}$ Ibid, p. 12.

${ }^{52}$ O Programa Brasil Alfabetizado (PBA) é voltado para a alfabetização de jovens, adultos e idosos e é desenvolvido em todo o território nacional, com o atendimento prioritário a municípios que apresentam alta taxa de analfabetismo, sendo que $90 \%$ destes localizam-se na região Nordeste. Mais informações em: <http://portal.mec.gov.br/programabrasil-alfabetizado>. Acesso em 07 out. 2019.
} 
Tabela 6 - Escolarização dos presos no Estado do Rio de Janeiro (2018)

\begin{tabular}{||l|c||c||}
\hline \multicolumn{1}{|c|}{ Escolaridade } & Quantidade & Percentual \\
\hline Acima de Superior & 6 & $0,01 \%$ \\
\hline Analfabetos & 603 & $1,17 \%$ \\
\hline Alfabetização & 2432 & $4,72 \%$ \\
\hline Apenas sabe assinar & 96 & 0,19 \\
\hline Ensino Fundamental Incompleto & 31106 & $60,40 \%$ \\
\hline Ensino Fundamental Completo & 4396 & $8,54 \%$ \\
\hline Ensino Médio Incompleto & 3844 & $7,46 \%$ \\
\hline Ensino Médio Completo & 3148 & $6,11 \%$ \\
\hline Ensino Superior Incompleto & 364 & $0,71 \%$ \\
\hline Ensino Superior Completo & 267 & $0,52 \%$ \\
\hline Não declarado & 5231 & $10,16 \%$ \\
\hline Sem informação & 11 & $0,02 \%$ \\
\hline \multicolumn{1}{|c|}{ TOTAL } & 51504 & $100 \%$ \\
\hline \hline
\end{tabular}

Fonte: Plano Estadual de Educação em Prisões - SEEDUC/RJ (2018, p.14)

Pereira (2018), ao analisar o conteúdo de 14 PEEPs, inclusive o do Estado do Rio de Janeiro, concluiu que a alfabetização de adultos é negligenciada, no sentido de não existir um projeto especifico de enfrentamento real do analfabetismo nas prisões.

Muitos concretizam a alfabetização a partir do Programa Brasil Alfabetizado (PBA), mas não informam como isso corre e qual o Programa estadual correspondente ao PBA, que é Federal, e que tem por finalidade dar assistência financeira aos estados, municípios e entidades privadas e públicas que implantem programas de alfabetização de jovens e adultos. Os estados precisam anexar aos seus PEEPs os programas de alfabetização apoiados pelo PBA. (PEREIRA, 2018, p. 245)

O PEEP/RJ reconhece que a oferta de educação nas prisões convive com problemas crônicos que dificultam a compreensão e a implementação de processos educacionais mais conectados a uma visão emancipadora de educação. ${ }^{53}$ Neste sentido, o PEEP/RJ cita Paulo Freire.

Paulo Freire afirmava que uma das grandes tarefas da educação é levar a humanidade a aprender a superar os limites colocados pelo cotidiano, inventando novas formas de viver, mais justas e solidárias. A tarefa de um educador, na perspectiva Freiriana, não é transmitir conteúdos, mas criar condições para a construção coletiva e crítica do conhecimento, aprendendo e ensinando com sentido, criando assim as condições possíveis para que os conhecimentos sejam construídos e reconstruídos pelos educandos ao lerem e relerem o mundo em que vivem. A formação do educador numa perspectiva emancipadora, baseada na concepção de educação libertadora, tal como defendia Paulo Freire, opta por maneiras democráticas e partilhadas de enfrentar os problemas do mundo,

${ }^{53}$ RIO DE JANEIRO, 2018. p.12. 
visando a contribuir para o fomento, nos processos educacionais, de uma Pedagogia de Direitos que promove a construção da participação cidadã de todos os segmentos sociais. (RIO DE JANEIRO, 2018, pp.12-13)

Percebe-se que o PEEP/RJ foi desenvolvido com base numa perspectiva freiriana que deveria servir como fator norteador para a educação nas prisões, mas necessita de teoria e de método para que seja de fato aplicada.

A SEEDUC/RJ, através do PEEP/RJ, instituiu a obrigatoriedade das unidades escolares existentes dentro das prisões do estado, a elaborar e/ou revisar seu Projeto Político Pedagógico, em conformidade com as necessidades e características da unidade escolar e unidade prisional, adequando os Projetos às rotinas das prisões e respeitando a vivência dos alunos e suas expectativas. $^{54}$

Conforme mencionamos no capítulo anterior, a Secretaria de Estado de Educação e a Secretaria de Estado de Administração Penitenciária firmaram um Termo de Cooperação Técnica que trata sobre o oferecimento da Educação Básica nos Estabelecimentos Penais do Estado do Rio de Janeiro. Segundo o PEEP/RJ, existia o entendimento entre as duas Secretarias da necessidade de documento mais específico, que abordasse situações do cotidiano dentro das unidades prisionais e que não estão contemplados no referido Termo. Para isto, no ano de 2017, foi firmado novo convênio entre a SEEDUC e a SEAP, publicado no Diário Oficial do Estado do Rio de Janeiro (DOERJ), com o objetivo de estabelecer normas de conduta para os servidores da SEEDUC que atuam nas unidades escolares prisionais e socioeducativas do estado.

${ }^{54}$ Ibid, p. 41. 
Figura 3 - Extrato de Termo do Convênio no 17/2017 firmado entre a SEAP e a SEEDUC

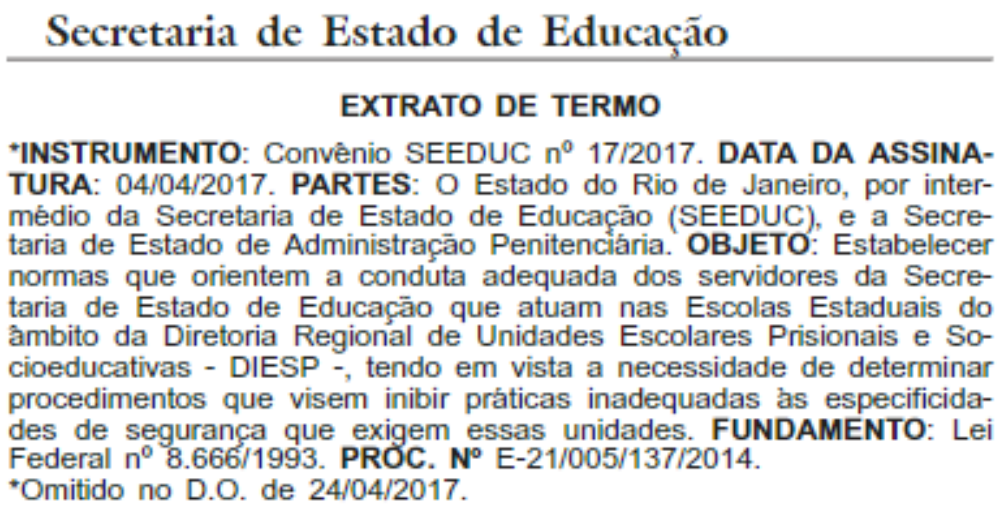

Id: 2032481

Fonte: DOERJ, Ano XLIII, nº 092, Parte I, de 22 de maio de 2017.55

Segundo o PEEP/RJ, a SEEDUC oferece aos professores as seguintes formações: a) Formação para professores alfabetizadores e dos anos iniciais do Ensino Fundamental; b) Formação para professores de Língua Portuguesa e Matemática; c) Participação de um Grupo de Professores na discussão do Currículo Mínimo da Rede Estadual de Ensino; d) 04 Fóruns de Educação em Prisões; e) 02 Seminários Etnocorraciais.

Como é possível verificar, não existe formação específica voltada para a atuação dos professores na educação prisional. É necessário, no entanto, que ocorra um investimento na formação continuada de todos os profissionais que atuam nas prisões, no sentido de estimular práticas de convivência mais tolerantes. Muitos professores iniciantes nem mesmo possuem experiências com o trabalho docente com jovens e adultos, pois poucas universidades investem em uma matriz curricular que possibilite a vivência em ambientes educacionais que fujam do cotidiano disposto pelo mercado de trabalho. Uma solução possível é a formação de educadores sociais, como descrito por Silva (2016).

Os professores da SEEDUC que atuam nas prisões são selecionados através de concurso público onde, na ocasião da inscrição, optam pelas Escolas do âmbito da Diretoria Especial de Unidades Escolares Prisionais e Socioeducativas - DIESP. No ano de 2008, conforme informa o PEEP/RJ, foi instituída uma gratificação especial para esses profissionais, bem como para os que atuam nos espaços do Departamento Geral de Ações Socioeducativas (DEGASE).

\footnotetext{
${ }^{55}$ Disponível em: < http://www.ioerj.com.br>. Acesso em 08 out. 2019.
} 
Tabela 7 - Gratificação Especial por função (2018)

\begin{tabular}{|l|c|}
\hline \multicolumn{1}{|c|}{ Cargo/Função } & \multicolumn{1}{|c|}{$\begin{array}{c}\text { Valor da GEE } \\
\text { Prisional/Socioeducativa }\end{array}$} \\
\hline Diretor de Escola & $\mathrm{R} \$ 700,00$ \\
\hline Diretor Adjunto de Escola & $\mathrm{R} \$ 550,00$ \\
\hline $\begin{array}{l}\text { Doc. I (Professor Regente do } 6^{\circ} \text { ano ao Ensino } \\
\text { Médio) }\end{array}$ & $\mathrm{R} \$ 516,00$ \\
\hline $\begin{array}{l}\text { Doc. II (Professor Regente do } 1^{\circ} \text { ano ao } 5^{\circ} \text { ano } \\
\text { do E.F.) }\end{array}$ & $\mathrm{R} \$ 450,00$ \\
\hline Secretário de Escola & $\mathrm{R} \$ 380,00$ \\
\hline Coordenador Pedagógico & $\mathrm{R} \$ 350,00$ \\
\hline Professor em função Extraclasse & $\mathrm{R} \$ 350,00$ \\
\hline Funcionários de Apoio & $\mathrm{R} \$ 300,00$ \\
\hline \hline
\end{tabular}

Fonte: Plano Estadual de Educação em Prisões - SEEDUC/RJ (2018, pp.45-46)

Considerando que esta gratificação especial não sofre reajuste desde o ano de sua criação, em 2008, o PEEP/RJ atualizado tenta justificar o fato informando que a Diretoria Regional de Unidades Escolares Prisionais e Socioeducativas elaborou um estudo em 2015 (7 anos após a implementação da gratificação), solicitando a atualização dos valores. Esta solicitação foi feita através do processo administrativo E-03/001/3965/2015 ${ }^{56}$, arquivado em 09/08/2019 sem conceder o referido reajuste. ${ }^{57}$

Em contrapartida, em maio de 2019, o governador Wilson Witzel concedeu um aumento das gratificações paga para alguns agentes da SEAP. Tratam-se dos diretores de unidades, subdiretores, chefes de segurança e disciplina, além de chefes de turma que atuam nas prisões do estado. Os gestores dos presídios, que recebiam gratificação de R \$ 1.300, agora terão um valor variado conforme a complexidade de cada unidade. Para as de alta complexidade, a bonificação passou para $\mathrm{R} \$ 5$ mil, um reajuste de quase $285 \%$. Nas de média, o valor foi para $\mathrm{R} \$ 3$ mil, ou $135 \%$ a mais. Já para as de baixa complexidade, os gestores receberão $\mathrm{R} \$ 2$ mil, $60 \%$ a mais. ${ }^{58}$

O PEEP/RJ estabeleceu 17 metas para a SEEDUC:

\footnotetext{
56 Disponível para consulta resumida em: <http://www.proderj.rj.gov.br/>. Acesso em 08 out. 2019.

${ }^{57}$ No período de elaboração desta tese cobramos através do E-SIC/RJ, o motivo para o arquivamento do processo. Até o momento não recebemos qualquer resposta por parte da SEEDUC.

58 Fonte: < https://odia.ig.com.br/rio-de-janeiro/2019/05/5642155-governo-anuncia-aumento-das-gratificacoes-paraagentes-da-seap.html\#foto=1>. Acesso em 10 out. 2019.
} 
1- Ampliar a cada cinco anos ao menos $20 \%$ a oferta de vagas da educação em todo o Sistema Prisional, garantindo acesso e permanência a todo indivíduo privado de liberdade;

2 - Garantir a cada semestre a ampliação da permanência de $100 \%$ dos estudantes matriculados;

3- Promover, até o final de 2016 a execução plena da matriz curricular implementada em 2015, por meio da participação ativa de toda comunidade escolar.

5- Assegurar, ao final da conclusão de cada nível de ensino a certificação de todos os alunos, bem como toda documentação comprobatória da vida escolar do estudante.

6- Avaliar sempre ao final de cada semestre se o efetivo de inspetores e seguranças penitenciários garantiram o pleno funcionamento da rotina escolar.

7-Encaminhar ao final de cada semestre se necessário os ajustes se o efetivo de inspetores e seguranças penitenciários garantiram o pleno funcionamento da rotina escolar.

8 - Garantir no início de cada semestre as condições necessárias ao pleno atendimento dos estudantes com necessidades especiais.

9 - Garantir no início de cada semestre o quantitativo de funcionários da SEEDUC que assegurem o pleno funcionamento.

10 - Promover até ao final de 2016 a consolidação da política de educação em prisões por meio da implementação de currículo, matriz curricular, elaboração de material didático e metodologia específica em consonância com as especificidades de sujeitos privados de liberdade, garantindo assim a qualidade social que esse direito exige

11- realizar ao início de cada bimestre, formação continuada dos professores em consonância com a política educacional implementada.

12- Promover ao final de cada dois anos a classificação das unidades escolares sempre que se fizer necessário.

13- Acolher todo profissional no momento de seu ingresso para atuar nas Unidades Escolares nos espaços de privação de liberdade.

14- Estabelecer anualmente política de reajuste da gratificação por lotação prioritária na DIESP.

15- Promover a cada dois anos Encontros, Palestras, Fóruns, Seminários e outras atividades pedagógicas que possibilitem, enquanto estratégias de formação continuada do profissional de educação que atua no sistema prisional a qualidade do ensino e a efetividade da aprendizagem do estudante.

16 - Implementar até o final de 2017 o $3^{\circ}$ turno nas UEs onde haja viabilidade, contemplando demanda, especificidade e respeitando as normas de segurança.

17 - Transferir até o final de 2015 a responsabilidade da planilha de remição de pena para os profissionais da SEAP. (RIO DE JANEIRO, 2018, pp. 47-48)

A maioria das metas elencadas dependem não só da SEEDUC mas de outros atores, como a SEAP e o próprio Governo do Estado. A primeira delas, que prevê a ampliação a cada cinco anos, de pelo menos $20 \%$ da oferta de vagas da educação em todo o Sistema Prisional, está relacionada com a construção de novas escolas ou a ampliação das escolas já existentes.

As metas 6 e 7 refletem as dificuldades encontradas na relação entre a SEEDUC e a SEAP que serão visualizadas de forma mais clara no terceiro capítulo desta tese. Entretanto, cabe destacar aqui duas necessidades já apresentadas até o momento, que exemplificam a relação entre as duas Secretarias: a elaboração pela SEAP, de um termo de conduta para os servidores da SEEDUC; e a 
avaliação por parte da SEEDUC, dos inspetores da SEAP, de modo a garantir o pleno funcionamento da rotina escolar.

A meta 10, que versa sobre a implementação de currículo, matriz curricular, elaboração de material didático e metodologia específica prevista para o ano de 2016, até hoje não foi cumprida. A formação continuada dos professores prevista na meta 11, acontece em parceria com a Fundação CECIERJ, entretanto, nenhum curso específico sobre a educação nas prisões é oferecido.

A meta 14, conforme já mencionamos, também não é cumprida, devido a inexistência de reajuste na gratificação especial dos professores da DIESP. A implementação do $3^{\circ}$ turno nas unidades educacionais também não foi possível até o momento, devido à entraves impostos pela SEAP no que diz respeito à segurança. A solução, neste caso, foi a implementação da modalidade semipresencial, que será tratada no próximo capítulo.

Segundo o PEEP/RJ, o sistema prisional possui 19 escolas estaduais que oferecem educação a nível Fundamental e Médio na modalidade Educação de Jovens e Adultos, além do Programa Brasil Alfabetizado. Para continuidade dos estudos, o PEEP/RJ informa que os internos podem participar do ENEM e de Exames Vestibulares, por meio de convênio com a UERJ, entretanto, não especifica que, caso o preso esteja em regime fechado, mesmo aprovado em vestibular, não poderá estudar sem autorização judicial. ${ }^{59}$

Além da educação básica, também são oferecidos em algumas unidades, cursos livres, oficinas de artes e palestras em parcerias firmadas pela SEEDUC. Sobre a remição de pena pelo estudo, o PEEP/RJ especifica que é encaminhado mensalmente ao juiz da Vara de Execução Penal do estado, cópia do registro de todos os alunos, com informação das horas de frequência escolar ou de atividades de ensino. Caso o interno tenha autorização para estudar fora do estabelecimento penal, este deve comprovar mensalmente, por meio de declaração da unidade de ensino, a frequência e o aproveitamento escolar. ${ }^{60}$

Apesar da publicação em 2013, da Recomendação CNJ nº 44/2013 que dispõe sobre atividades educacionais complementares para fins de remição da pena pelo estudo e estabelece critérios para a admissão pela leitura, o PEEP/RJ atualizado em 2018, não menciona a metodologia

\footnotetext{
${ }^{59}$ Não se tem conhecimento de nenhum preso que tenha conseguido autorização judicial para cursar o nível superior fora da prisão, estando em regime fechado. Apenas os internos que cumprem pena em regime semiaberto são autorizados a sair para estudar durante o dia, retornando a prisão no turno da noite.

${ }^{60}$ RIO DE JANEIRO, 2018, p. 59.
} 
utilizada para esta questão, apenas cita na meta 17, a necessidade de se transferir a responsabilidade da remição de pena para os profissionais da SEAP.

Por outro lado, é possível perceber através dos dados apresentados no Plano, que nem todas as unidades possuem sala de leitura e/ou biblioteca. Sobre a remissão da pena pela leitura, o estudo de Pereira (2018) relata tratar-se de um direito que não está sendo concretizado.

Os PEEPs não apresentam um projeto estruturado de leitura efetiva sob a orientação, a supervisão e a execução de professores de Português e de pedagogos, com a adequada avaliação da aprendizagem das pessoas presas. Lembramos de que a remição da pena pela leitura não é apenas reduzir o tempo de privação de liberdade mas, sobretudo, a formação de sujeitos leitores. (PEREIRA, 2018, p.247)

O PEEP/RJ também estabelece 9 metas para a SEAP:

1 - Viabilizar a construção e reforma dos espaços físicos das Unidades Escolares, adaptando e/ou ampliando segundo as necessidades da proposta pedagógica, de acordo com a disponibilidade de espaço da Unidade Prisional.

2 - Assegurar ao aluno acesso à qualificação profissional.

3 - Construção de novas Unidades Escolares nos espaços de privação de liberdade onde não exista a oferta da Educação Básica, em atendimento ao Termo de Cooperação Técnica entre SEEDUC e SEAP.

4 - Diminuir o índice de evasão escolar.

5 - Promover a integração laboral e social entre todos os envolvidos no processo educacional.

6 - Priorizar a matrícula escolar ao interno que cumprir as exigências da SEEDUC/DIESP.

7 - Viabilizar parcerias com instituições públicas e privadas que promovam a qualificação profissional do aluno.

8 - Estabelecer até ao final de 2017 o Ensino Superior à distância.

9 - Estabelecer até ao final de 2017 procedimentos que garantam a oferta por parte da direção da unidade prisional de atividades culturais, esportivas e de qualificação profissional. (RIO DE JANEIRO, 2018, p. 63)

As metas apresentadas carecem de uma metodologia de acompanhamento e avaliação mais sistemática para que sejam de fato aplicadas. Reformar e construir novas unidades escolares nas prisões é algo que necessita de planejamento e financiamento público. O PEEP/RJ apresenta tais metas mas não especifica como elas podem ser alcançadas, como é o caso da meta 4 - diminuir o índice de evasão escolar.

Conforme já mencionamos no capítulo anterior, ao longo dos anos, a SEEDUC e a SEAP tentaram atingir a meta de número 8, no sentido de implementar o Ensino Superior à distância no Complexo Penitenciário de Gericinó, entretanto, até o momento isto não foi possível. 
Por fim, o PEEP/RJ traz em suas considerações finais a responsabilidade das instituições públicas envolvidas na elaboração do Plano, no sentido de garantir a oferta da educação básica e da qualificação profissional nas prisões. Também estabelece que o documento deverá ser revisto e atualizado a cada dois anos.

Segundo Pereira (2018), os Planos Estaduais de Educação em Prisões, mesmo precisando de ajustes, se mostram como uma boa esperança de uma educação de qualidade no sistema prisional. O PEEP/RJ, apesar de suas limitações, se constitui em um instrumento de suma importância para a garantia do direito a educação para todos. 


\section{OS LIMITES E AS NOVAS POSSIBILIDADES ENTRE A EDUCAÇÃO E AS PRISÕES}

Com base nos subsídios teóricos dos capítulos anteriores, pretende-se aqui, analisar, através de documentos coletados e de pesquisa de campo, os marcos operacionais para o exercício do direito à educação por parte da população prisional do Estado do Rio de Janeiro, identificando novas possibilidades de atuação Secretaria de Estado de Educação (SEEDUC) nas unidades prisionais no sentido de estabelecer condições que garantam o acesso à educação para todos.

Conforme especificamos no capítulo anterior, iremos investigar o processo de implantação das Diretrizes Nacionais para a Oferta da Educação em Estabelecimentos Penais (BRASIL, 2010) no contexto prisional do Estado do Rio de Janeiro, considerando às categorias enunciadas nos três eixos do Projeto Educando para a Liberdade (UNESCO, 2006), que serão parte da análise do material coletado.

A pesquisa de campo se deu de forma qualitativa, com o objetivo de proporcionar uma análise diagnóstica mais aprofundada sobre a temática. Optamos por utilizar uma abordagem que valorize as interações e as relações humanas, por entender que os objetos de estudo das ciências humanas e sociais são as pessoas carregadas de histórias e de valores.

Neste sentido, apesar de se tratar de uma pesquisa diagnóstica ao buscar investigar a efetiva capacidade do Estado do Rio de Janeiro em cumprir a lei, também nos guiamos pelo viés de uma abordagem qualitativa atrelada aos campos da Educação e do Direito, preocupando-se com aspectos da realidade dos sujeitos e com a compreensão da dinâmica das relações sociais. Tomando como base os estudos de Bogdan \& Biklen (1994), o método de condução da investigação aqui desenvolvida reflete uma espécie de diálogo entre o investigador e os respectivos sujeitos, resultando num processo contínuo de questionamentos.

A pesquisa-diagnóstico, na visão de Diehl \& Tatim (2004, p.57), “permite não só o diagnóstico, como também a racionalização dos sistemas”. Desta forma, a análise documental será atrelada à pesquisa de campo de modo que permita a verificação da prática de implementação dos processos detalhados nas Diretrizes, no Plano Estadual de Educação nas Prisões e no Projeto Político Pedagógico do colégio escolhido.

Em uma pesquisa científica, quando se trata de apreciar as peculiaridades de uma determinada população, é comum, segundo Diehl \& Tatim (2004, p. 63), “observar apenas uma amostra de seus elementos e, a partir dos resultados dessa amostra, obter valores aproximados, ou 
estimativas, para as características de interesse". Com base nisto e considerando as limitações da pesquisa, realizamos entrevistas com 12 pessoas, sendo 5 alunos, 6 professores e 1 diretora.

Lakatos \& Marconi (2003) definem entrevista como um encontro entre pessoas onde são obtidas informações a respeito de determinado assunto, através de uma conversação. "É um procedimento utilizado na investigação social, para a coleta de dados ou para ajudar no diagnóstico ou no tratamento de um problema social” (LAKATOS \& MARCONI, 2003, p. 195).

As entrevistas realizadas foram fundamentais pois possibilitaram o conhecimento de diversos pontos de vista sobre a educação na prisão, contribuindo para atingir os objetivos desta pesquisa. Por meio dos entrevistados, de suas falas e de suas histórias de vida compreendemos melhor os espaços em que estão inseridos: a escola e a prisão.

$\mathrm{O}$ acesso restrito aos documentos e a burocracia imputada pelo Estado do Rio de Janeiro aos pesquisadores nos fizeram percorrer caminhos diversos dos que foram projetados no início do curso de doutorado em Educação. Essa pesquisa esbarrou em inúmeros entraves no acesso às informações que, na teoria, deveriam ser públicas. Os principais problemas encontrados serão relatados a seguir.

\subsection{As dificuldades encontradas durante a pesquisa e suas adaptações}

Nos anos iniciais do curso de Doutorado, nos debruçamos sobre a análise bibliográfica a respeito da temática aqui desenvolvida. A partir do exame de qualificação demos início a coleta de dados documentais que pudessem subsidiar essa pesquisa e delimitar caminhos a serem percorridos na busca por atingir os objetivos definidos.

Iniciamos esse percurso no mês de outubro de 2018, realizando consulta pública de documentos através do Sistema Eletrônico de Informações ao Cidadão (E-SIC) gerenciado pelo Governo do Estado do Rio de Janeiro.

A primeira consulta solicitou a Secretaria de Administração Penitenciária (SEAP) o quantitativo exato de pessoas privadas de liberdade em todas as unidades prisionais do Estado. Tivemos nosso pedido indeferido, sob o seguinte argumento:

Protocolo 3186:

Prezados,

Conforme o Decreto n 46475, cap. V, artigo 25 - a informação não poderá ser divulgada: 
VI- "prejudicar ou causar risco a planos ou operações estratégicos dos órgão de segurança do Estado"

Em 2019, após as eleições e a posse do Governador Wilson Witzel (PSC), alguns sites das secretarias do Estado foram retirados do ar, entre eles os sites da SEAP e da SEEDUC, principais fontes de consulta de Resoluções, Decretos, Leis e documentos relacionados à regulamentação da educação nas prisões do Rio de Janeiro. ${ }^{61}$

Devido à mudança de governo, optamos por solicitar novamente através de consulta pública, o quantitativo atualizado de pessoas privadas de liberdade por unidade prisional no Estado. Desta vez direcionamos a consulta ao próprio Governo do Estado, explicando que o nosso objetivo era fundamentar pesquisa acadêmica de doutorado em Educação da Universidade de São Paulo. Também informamos que os dados foram fornecidos pelo Estado no ano de 2016, ao Departamento Penitenciário Nacional, e divulgados no Levantamento Nacional de Informações Penitenciárias, em 2017. Recebemos a seguinte resposta:

Protocolo 3699:

Prezada Cidadã,

Informamos que não somos o órgão responsável pelas informações solicitadas. Assim, RECOMENDAMOS que a solicitação seja remetida à Secretaria de Estado de Administração Penitenciária.

Respeitosamente, Equipe da Ouvidoria e Transparência Geral do Estado.

Ao remeter a solicitação para a SEAP, através do protocolo $\mathrm{n}^{\circ} 6567$, fomos respondidos com um parecer da Subsecretaria Adjunta de Gestão Operacional, indeferindo o pedido.

Cumprimentando-o, restituímos o presente indeferindo o pedido, com fulcro no art.37, $\S 3^{\circ}$, inciso II da CRFB/1998 e art. 23, inciso VIII da Lei 12.257/2011, ressaltando imprescindibilidade do sigilo à segurança da sociedade e do Estado, tendo em vista que os bancos de dados referentes aos apenados, servidores e demais profissionais que possuem relação com a SEAP-RJ, não se encontram abertos, devido à vulnerabilidade que traria a estes cidadãos, um por se encontrar preso, outro por ser responsável por sua custódia no cumprimento da pena, ou por estarem prestando serviço à SEAP-RJ. É de conhecimento da Nação o Direito de Acesso à Informação, principalmente, no que se

61 Os sites permaneceram fora do ar até a data de depósito desta tese (14/10/2019). São eles: <http://www.seap.rj.gov.br>e <http://www.seeduc.rj.gov.br>. 
refere a prestação de serviços do Estado, entretanto, cumpre informar que, segundo o entendimento desta SEAP-OP, a demanda em exame, possui relação direta com a fragilização da Segurança e risco de exposição das atividades de inteligência, custódia, investigação, fiscalização e demais procedimentos que estejam em curso na forma da legislação supracitada.

Documento assinado eletronicamente por Jurema Sodré da Silva, Assessora, em 09/09/2019.

Em um ato de resistência, entramos com recurso em segunda instância diante da contradição existente na justificativa de indeferimento que se baseia no art. 23, VIII, da Lei 12.527/11, alegando que a divulgação dos dados solicitados poderia "comprometer atividades de inteligência, bem como de investigação ou fiscalização em andamento, relacionadas com a prevenção ou repressão de infrações". Nos baseamos novamente no argumento de que o quantitativo de pessoas privadas de liberdade no Estado é frequentemente divulgado através do Levantamento Nacional de Informações Penitenciárias - INFOPEN, documento público e de relevância nacional. A solicitação dos respectivos dados visava apenas atualizar os números que já constam no referido Levantamento.

Nosso recurso foi respondido diretamente pelo Subsecretário de Estado de Administração Penitenciária, Ricardo Alexandre Romar Naldoni, que manteve o indeferimento do pedido.

À Ouvidoria - SEAP/OU

Em retorno, informo que a solicitação da Sra. Taíza da Silva Gama foi INDEFERIDA, de acordo com os motivos apresentados pela Subsecretaria Adjunta de Gestão Operacional - SEAP/OP.

Documento assinado eletronicamente por Ricardo Romar Naldoni, Subsecretário de Estado, em 16/09/2019

Durante o ano de 2018 realizamos várias consultas aos documentos da Secretaria de Estado de Educação (SEEDUC). Devido às constantes negativas da SEAP, a maioria dos dados quantitativos utilizados nesta tese foram decorrentes do Plano Estadual de Educação em Prisões atualizado em 2018 por solicitação de nossa pesquisa.

Decidimos eleger como objeto de estudo a unidade escolar prisional pela qual conseguimos maior número de dados na fase da pesquisa documental: o Colégio Estadual José Lewgoy, localizado no Complexo Penitenciário de Gericinó, no bairro de Bangu. Esse fato se deu porque, ainda em 2018, solicitamos informações sobre a existência de algum Projeto Político Pedagógico 
para a educação em prisões no Estado do Rio de Janeiro. Na ocasião, nos foi esclarecido que cada unidade escolar possuía um Projeto, e a SEEDUC nos enviou o PPP do Colégio Estadual José Lewgoy como exemplo.

Após definirmos a unidade escolar, abrimos o processo E-21/087.27/2019 no Centro de Estudos e Pesquisas (CEP) da SEAP, com o objetivo de autorizar a pesquisa e, consequentemente, o acesso à Penitenciária Moniz Sodré, onde está localizado o Colégio Estadual José Lewgoy.

A Resolução SEAP n 671 , de 28 setembro de 2017, estabeleceu critérios para a realização de pesquisas nas unidades prisionais do Estado devido ao aumento constante na demanda de solicitações por diversas instituições de ensino e pesquisadores de vários segmentos. A Resolução determina que todo e qualquer tipo de solicitação para realização de pesquisa junto à SEAP seja iniciada pelo pesquisador junto ao CEP.

Para iniciar o processo tivemos que preencher um formulário com diversas perguntas de cunho pessoal onde também constava um termo de compromisso.

Compromisso do pesquisador:

$\mathrm{Eu}$, pesquisador, me comprometo a informar ao Centro de Estudos e Pesquisa da Escola de Gestão Penitenciária, qualquer alteração na pesquisa que ora solicito autorização para iniciar nessa Secretaria, bem como encaminhar após o término da mesma, uma cópia do trabalho para ser colocada na Biblioteca da Escola de Gestão Penitenciária e que todos possam ter acesso a este trabalho.

Declaro inclusive, que as respostas por mim fornecidas no formulário para requerimento de pesquisa junto à SEAP, representam a exata expressão da verdade.

Qualquer omissão, inexatidão, infidelidade ou falsidade que possuam, incorrerei nas penas do crime de falsidade ideológica, capitulada no artigo 299 do Código Penal Brasileiro.

Ciente de que todos os dados e informações fornecidos são verdadeiros, assino o presente documento me comprometendo a informar qualquer alteração dessas informações no decorrer da pesquisa.

Além do formulário, entregamos declaração de matrícula na USP, cópias de RG, CPF, comprovante de residência, documento de veículo, uma cópia do projeto de pesquisa impressa e outra em CD.

Após a instauração, o processo foi encaminhado à Superintendência de Inteligência do Sistema Penitenciário (SISPEN), onde todos os dados fornecidos foram verificados. A SISPEN retornou a solicitação para o CEP solicitando a assinatura de termo de compromisso para não utilização de equipamento eletrônico. 
$\mathrm{Eu}$, RG me comprometo a respeitar a condição de não utilizar equipamentos eletrônicos (ex. máquinas fotográficas, gravadores e etc.), bem como, quando for o caso, de manter o anonimato dos internos, nas entrevistas realizadas durante a pesquisa. Comprometo-me, ainda, a não reproduzir documentos pertencentes à Unidade Prisional a ser pesquisada, que caso necessário, só serão manuseados a título de consulta.

A Resolução SEAP n ${ }^{\circ}$ 671/2017, em seu artigo $8^{\circ}$, determina que, nas pesquisas que utilizem imagens das Unidades Prisionais sob a administração da SEAP, tais filmagens, gravações e fotografias, somente serão autorizadas pelo Secretário da Pasta se forem de cunho científico. Entretanto, ao analisarmos a bibliográfica sobre a temática da educação em prisões no Rio de Janeiro, percebemos que servidores da SEAP e da SEEDUC puderam utilizar em suas pesquisas gravadores e câmeras fotográficas, configurando um desrespeito ao princípio da isonomia em relação à esta tese.

Depois de assinarmos o termo de compromisso, a pesquisa foi autorizada pelo Subsecretário de Estado de Administração Penitenciária Ricardo Alexandre Romar Naldoni. ${ }^{62}$

No Estado do Rio de Janeiro não existe um Comitê de Ética em Pesquisa. Por este motivo, as pesquisas que envolvem pessoas privadas de liberdade devem passar por autorização do Juiz da Vara de Execuções Penais do Estado. Essa autorização precisa ser viabilizada pelo próprio pesquisador. Diante disto, nos dirigimos à VEP para protocolar a solicitação de autorização da pesquisa, que fora concedida pelo Juiz Dr. Rafael Estrela Nóbrega.

A pesquisa foi realizada na unidade prisional durante o mês de setembro. As entrevistas se deram sem o uso do gravador e durante o horário de aula. A Resolução SEAP nº 671/2017 também determina que as pesquisas só podem ser efetuadas no período de 10:00 às 15:00 horas, em dias úteis que não tenham visitação de familiares e sem prejuízo das atividades normais da unidade a ser visitada.

A dinâmica da escola prisional durante o horário das $10 \mathrm{~h}$ às $15 \mathrm{~h}$ não permite interrupções longas para a realização de conversas e entrevistas. Desta forma, as entrevistas semiestruturadas que elaboramos foram realizadas com a diretora da unidade e com alguns alunos. Quanto aos professores, optamos pela realização de uma entrevista em grupo durante o horário de almoço, no

\footnotetext{
62 Trata-se do mesmo subsecretário que indeferiu o pedido de informação realizado através do E-SIC, sobre o quantitativo de presos do Estado.
} 
refeitório da unidade. Esse procedimento não foi, a nosso ver, o mais adequado, mas sim, aquele viabilizado durante o período da pesquisa de campo e diante de todas as dificuldades já relatadas.

Utilizamos três roteiros de entrevistas que podem ser conferidos na íntegra, nos anexos desta tese. Como roteiro da entrevista em grupo, empregamos as mesmas temáticas estabelecidas na entrevista semiestruturada realizada com a diretora da unidade. Escolhemos não realizar entrevistas fora do ambiente prisional por considerarmos importante que os professores entrevistados falassem no universo em que estão inseridos e com as interferências do dia a dia da unidade escolar.

Desta forma, foram definidos três eixos de análise: 1) o espaço escolar; 2) o aluno do Colégio Estadual José Lewgoy, 3) a experiência docente. No primeiro eixo iremos situar a escola descrevendo seus espaços e analisando o seu Projeto Político Pedagógico considerando as categorias enunciadas no Projeto Educando para a Liberdade (UNESCO, 2006). No segundo eixo, a partir das entrevistas realizadas, traçaremos o perfil do aluno do Colégio Estadual José Lewgoy, elencando o que pensam sobre a escola e suas perspectivas para o futuro. O terceiro eixo recai o olhar para as práticas pedagógicas a partir das experiências dos professores e da direção da unidade.

Ao final do capítulo, apresentaremos os limites e os desafios encontrados ao longo da pesquisa, de forma a contribuir para a melhoria da educação nas prisões do Estado do Rio de Janeiro.

\subsection{O espaço escolar: o Colégio Estadual José Lewgoy e o seu Projeto Político Pedagógico}

O Eixo 3 do Projeto Educando para a Liberdade (UNESCO, 2006), que trata sobre “aspectos pedagógicos", atenta para a necessidade de se criar um regimento escolar próprio para o atendimento nos estabelecimentos de ensino do sistema prisional, no intuito de preservar a unidade filosófica, político-pedagógico estrutural e funcional das práticas de educação nas prisões. Desta forma, também determina que seja elaborado em cada estado os seus projetos pedagógicos próprios para a educação nas prisões, contemplando as diferentes dimensões da educação (escolarização, cultura, esporte e formação profissional), considerando a realidade do sistema prisional para a proposição das metodologias.

No Estado do Rio de Janeiro cada unidade escolar possui um Projeto Político Pedagógico próprio, formulado com base no Plano Estadual de Educação e no Plano Estadual de Educação em 
Prisões. Tanto os Planos quanto o PPP foram elaborados com o objetivo de atender as Diretrizes Nacionais para a Oferta de Educação nos estabelecimentos penais, onde estão incluídos os três eixos do Projeto Educando para a Liberdade (UNESCO, 2006).

O PPP do Colégio Estadual José Lewgoy foi formulado em 2017, pela então Diretora Regional Pedagógica e Administrativa da DIESP, professora Maria Minerva de Medeiros Valle ${ }^{63}$. O Projeto é dividido da seguinte forma: 1) dados de identificação; 2) apresentação da escola; 3) justificativa; 4) filosofia/metodologia de ensino da instituição; 5) objetivos gerais; 6) objetivos específicos; 7) método de verificação de aprendizagem; 8) controle de frequência/remissão de pena; e 9) memória e letramento: construção da autonomia.

Esclarecemos que o último tópico mencionado acima trata sobre um projeto, escrito em primeira pessoa e a partir de observações que imaginamos ser da professora Maria Minerva de Medeiros Valle, onde é proposta a apresentação da importância do letramento na formação dos alunos do Colégio. Diante disto, no nosso ponto de vista, o PPP se constitui somente até o item 8 - controle de frequência/remissão de pena - considerando que o item 9 deveria fazer parte de um de seus anexos.

Apesar de citar o artigo 14 da LDB, que versa sobre a participação de profissionais da educação na elaboração do projeto pedagógico da escola, percebe-se ao analisar o PPP, que ele não foi construído de forma coletiva de modo a propiciar a participação e a escuta de todos os atores envolvidos nos processos da unidade escolar. Acreditamos que o PPP só é legítimo do ponto de vista político-institucional e pedagógico quando é resultante da participação democrática de seus agentes.

Sabemos que, apesar de necessário, existem inúmeros entraves no processo de construção de um Projeto Político Pedagógico na perspectiva dialógica e democrática. Arroyo (2003) afirma que todo projeto pedagógico é um projeto de professor que provoca embates, resistências, divide grupos ou aproxima.

Os embates tocam em nossas áreas, em nossos terrenos e quintais. Se o projeto é do coletivo da escola, fica ultrapassado falar em minha turma, minha disciplina, meus conteúdos, meus aprovados e reprovados; nossas tranquilidades ou inseguranças ficam expostas. (ARROYO, 2003, p. 173).

\footnotetext{
${ }^{63}$ Informação dada pela diretora do Colégio Estadual José Lewgoy, professora Lania Régia Alves, durante a pesquisa de campo.
} 
Para Veiga (2007), “construir, executar e avaliar o projeto político-pedagógico significa preocupar-se com a qualidade da escola, ou seja, uma escola que garanta as condições de trabalho necessárias para o desenvolvimento do processo pedagógico" (VEIGA, 2007, p. 04). Assim, mesmo diante de problemas que venham a ser encontrados, a construção do Projeto Político Pedagógico pode constituir-se num dos mais importantes instrumentos da gestão democrática de uma escola, se assegurada a participação dos envolvidos em suas decisões e responsabilidades.

O PPP do Colégio Estadual José Lewgoy se inicia com uma breve identificação e apresentação. Especifica que o Colégio foi criado em 2006, através do Decreto nº 38.997/06, e está localizado no bairro de Bangu, município da cidade do Rio de Janeiro. É responsável por atender as pessoas que se encontram em privação de liberdade na Penitenciária Moniz Sodré (público masculino), que integra com mais 24 unidades prisionais, o Complexo Penitenciário de Gericinó.

A Penitenciária possui 2381 pessoas privadas de liberdade ${ }^{64} \mathrm{em}$ regime semiaberto ${ }^{65} \mathrm{e}$, em sua maioria, são jovens entre 18 e 25 anos, que possuem o ensino fundamental incompleto (1558 deles), conforme indica a tabela abaixo.

Tabela 8 - Escolaridade dos presos da Penitenciária Moniz Sodré (2018)

\begin{tabular}{||l|r||r||}
\hline \multicolumn{1}{|c|}{ ESCOLARIDADE } & \multicolumn{1}{c|}{ Quantidade } & \multicolumn{1}{c||}{ Percentual } \\
\hline Alfabetizado & 98 & $4.12 \%$ \\
\hline Analfabeto & 23 & $0.97 \%$ \\
\hline Apenas sabe Assinar & 3 & $0.13 \%$ \\
\hline Fundamental Incompleto & 1558 & $65.43 \%$ \\
\hline Fundamental completo & 193 & $8.11 \%$ \\
\hline Médio completo & 82 & $3.44 \%$ \\
\hline Médio incompleto & 190 & $7.98 \%$ \\
\hline Não Informado & 223 & $9.37 \%$ \\
\hline Superior Completo & 2 & $0.08 \%$ \\
\hline Superior Incompleto & 9 & $0.38 \%$ \\
\hline \multicolumn{1}{|c|}{ TOTAL } & 2381 & $100 \%$ \\
\hline
\end{tabular}

Fonte: Plano Estadual de Educação em Prisões (RIO DE JANEIRO, 2018)

\footnotetext{
${ }^{64} \mathrm{O}$ quantitativo de presos foi descoberto através do Plano Estadual de Educação em Prisões que nos foi enviado no ano de 2018, entretanto, após concluirmos nossa pesquisa de campo em setembro de 2019, nos foi informado por um Inspetor da unidade, que a Penitenciária já estava atingindo a marca dos 3000 presos.

${ }^{65}$ O Procedimento Especial no 2016/0053155-0 da Defensoria Pública do Estado do Rio de Janeiro, pediu, em 2016, a interdição funcional da Penitenciária Moniz Sodré para o regime semiaberto em virtude de sua absoluta inadequabilidade para tal forma de cumprimento de pena. $\mathrm{Na}$ ocasião, a Penitenciária atendia também ao regime fechado. A Defensoria Pública solicitou a concessão de prisão domiciliar para 660 presos que estavam no regime semiaberto. A solicitação foi negada e, em 2018, a unidade passou a atender somente aos presos do regime semiaberto.
} 
O Colégio possui atualmente 141 alunos matriculados com idade acima de 18 anos, sendo a $7^{\text {a }}$ unidade escolar prisional com maior número de alunos no Estado do Rio de Janeiro.

Tabela 9 - Quantitativo de alunos matriculados por unidade escolar prisional (2019)

\begin{tabular}{|c|c|c|}
\hline \multicolumn{2}{|c|}{ UNIDADE ESCOLAR } & TOTAL DE ALUNOS \\
\hline 1 & CE THEODORO SAMPAIO & 66 \\
\hline 2 & C.E. MARINHEIRO JOÃO CÂNDIDO & 42 \\
\hline 3 & CE RUBEM BRAGA & 122 \\
\hline 4 & CE ANGENOR DE OLIVEIRA CARTOLA & 230 \\
\hline 5 & CE PROFESSOR CARLOS DA COSTA & 195 \\
\hline 6 & CE PROFESSORA ALDA LINS FREIRE & 243 \\
\hline 7 & CE PROFESSORA SONIA MARIA MENEZES SOARES & 208 \\
\hline 8 & CE JOSE LEWGOY & 141 \\
\hline 9 & CE EVANDRO JOAO DA SILVA & 208 \\
\hline 10 & CE MARIO LAGO & 116 \\
\hline 11 & CE MARIA MONTESSORI & 122 \\
\hline 12 & CE PRIMEIRO TENENTE PM HAILTON DOS SANTOS & 102 \\
\hline 13 & CE PADRE BRUNO TROMBETTA & 274 \\
\hline 14 & CE ESCRITOR E JORNALISTA GRACILIANO RAMOS & 168 \\
\hline & TOTAL & $\mathbf{2 2 3 7}$ \\
\hline
\end{tabular}

Fonte: Secretaria de Estado de Educação (SEEDUC/RJ) ${ }^{66}$

O Colégio Estadual José Lewgoy funciona em dois turnos - manhã (9:00h às 12:00h) e tarde (13:00h às 16:00h) - numa estrutura que era uma galeria, cujas celas foram transformadas em seis salas de aula, onde também são guardados os materiais didáticos. Além das salas, há um espaço administrativo pedagógico e dois banheiros.

A seguir é possível observar uma foto cujo objetivo é mostrar a estrutura externa do Colégio. Na imagem podemos perceber que somente metade da galeria é utilizada para fins educativos. As duas quadras de esporte que aparecem na figura não fazem parte do Colégio, que também não possui pátio, refeitório, laboratório de informática, sala de leitura e/ou biblioteca.

\footnotetext{
${ }^{66}$ Dados fornecidos em 13/09/2019 através de consulta pública pelo E-SIC - Protocolo 6598.
} 
Figura 4 - Colégio Estadual José Lewgoy

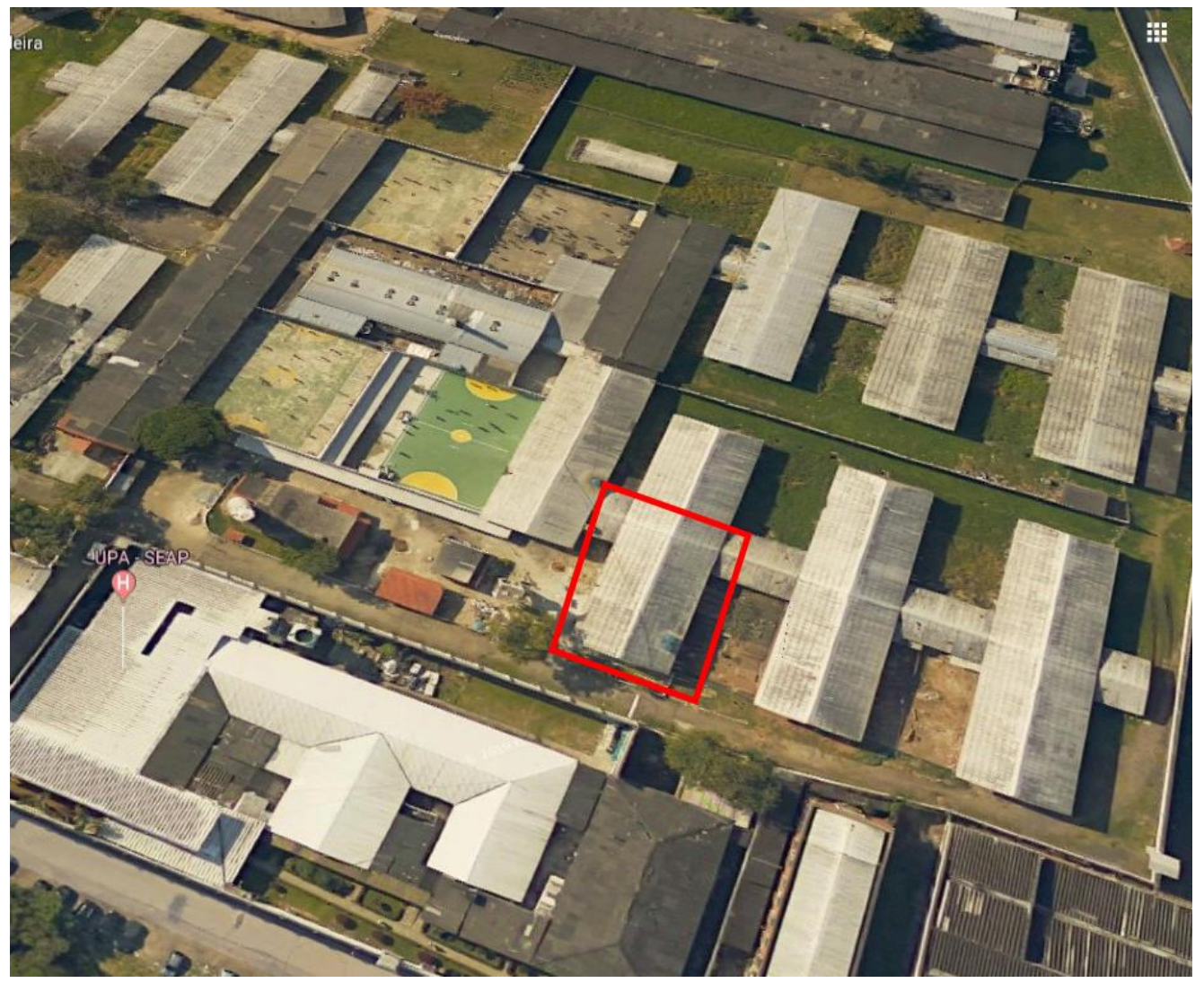

Fonte: Google Maps, 2019. ${ }^{67}$

Em cada sala de aula há um quadro branco, um armário, um aparelho de ar condicionado, ventiladores, carteiras, mesa para o professor e iluminação. Segundo o Projeto Político Pedagógico $(\mathrm{PPP})^{68}$ do Colégio, “as salas não são muito ventiladas pois não há janelas e os ares condicionados funcionam deficientemente por conta da parte elétrica da Unidade Prisional não estar adequada para os aparelhos".

A direção e a parte administrativa e pedagógica ficam separadas do Colégio, no prédio onde funcionam os outros setores administrativos da unidade prisional. Possuem uma sala reservada com duas mesas com computadores, aparelho de telefone, um armário que guarda materiais escolares e um freezer que guarda as merendas perecíveis em uma pequena dispensa. O

67 Disponível em: <https://www.google.com/maps/place/Complexo+Penitenci\%C3\%A1rio+de+Gericin \%C3\%B3/@-22.8469115,-43.4851101,193a,35y,10.44h,44.95t/data=!3m1!1e3!4m8!1m2!2m1!1 smoniz+sodr\%C3 \%A9!3m4!1s0x996021a8164903:0x862431203b72154d!8m2!3d-22.8423544!4d-43.4831517>. Acesso em 11 out. 2019.

${ }^{68}$ Documento completo em anexo. 
espaço conta também com dois arquivos com as fichas dos alunos inativos e quatro armários para armazenar merenda e guardar documentos da unidade escolar. ${ }^{69}$ No mesmo prédio funciona o refeitório onde os inspetores e os professores realizam suas refeições.

Pretendemos localizar, por meio da imagem abaixo, o local onde funciona a sala administrativa citada acima e a galeria destinada ao Colégio, para que seja possível verificar a distância percorrida entre ambos os ambientes e as formas de interferências desses espaços na rotina diária da unidade escolar.

Figura 5 - Distância entre o Colégio Estadual José Lewgoy e o prédio onde ficam a sala administrativa e o refeitório dos funcionários

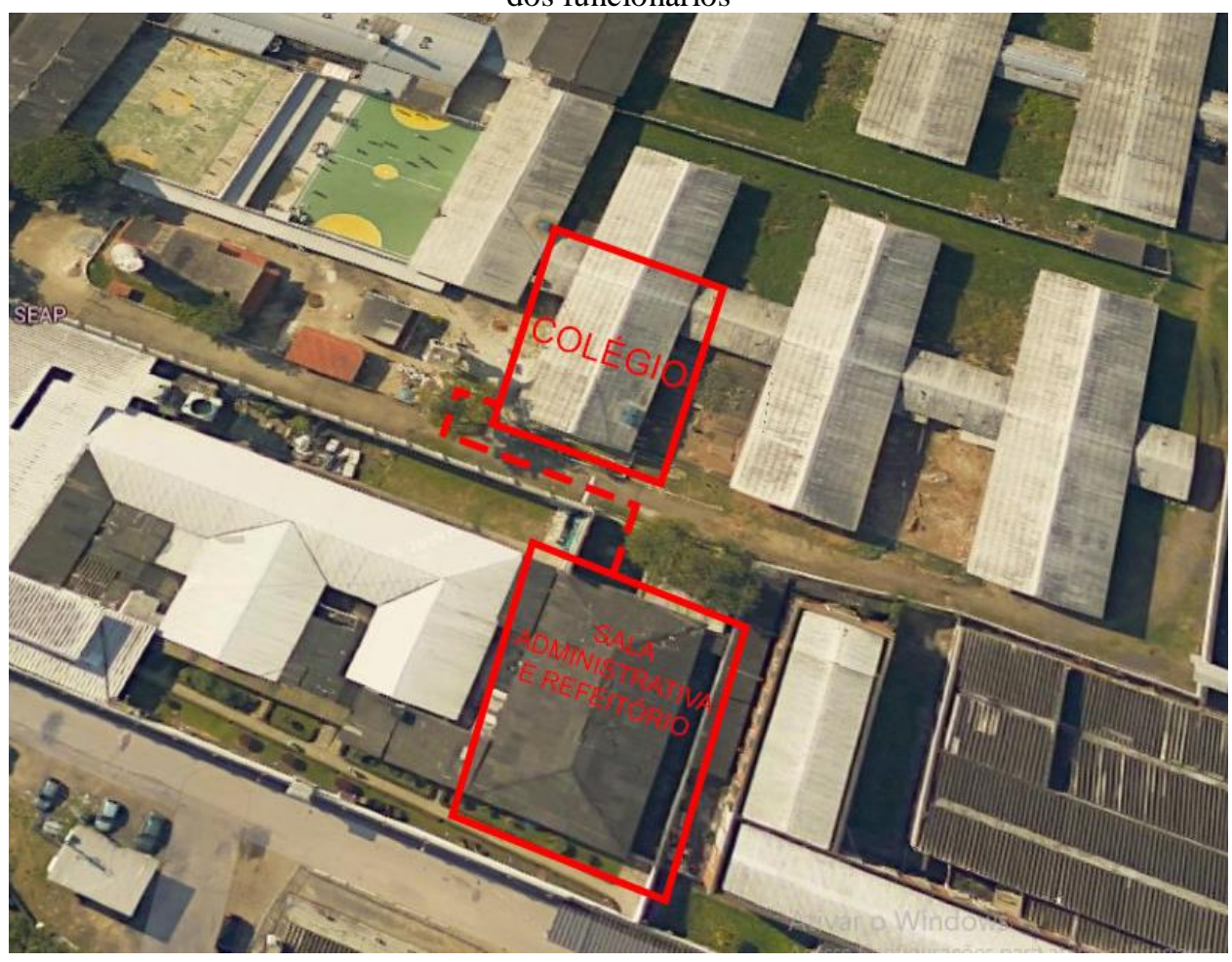

Fonte: Google Maps, 2019. ${ }^{70}$

Segundo o PPP, “devido ao espaço físico inadequado ocupado pela escola, fica inviável atender a demanda de internos que têm o desejo de estudar, por isso o número muito reduzido em relação ao número de internos" (RIO DE JANEIRO, 2018, p. 05).

${ }^{69}$ RIO DE JANEIRO, SEEDUC, 2018.

$70 \quad$ Disponível em: <https:/www.google.com/maps/place/Complexo+Penitenci\%C3\%A1rio+de+ Gericin\%C3\%B3/@-22.8469115,-43.4851101,193a,35y,10.44h,44.95t/data=!3m1!1e3!4m8!1m2!2m1!1smoniz+so dr\%C3\%A9!3m4!1s0x996021a8164903:0x862431203b72154d!8m2!3d-22.8423544!4d-43. 4831517>. Acesso em 11 out. 2019. 
Neste sentido, podemos verificar que existe uma intenção por parte da SEEDUC em ampliar a unidade de modo a atingir o maior número de alunos possível, entretanto, conforme estabelecido no primeiro eixo do projeto Educando pela Liberdade, a oferta de educação no sistema prisional deve ser fruto de uma articulação entre os órgãos responsáveis pela Administração Penitenciária e pela Secretaria de Educação, cabendo a ambos a responsabilidade pela gestão e pela coordenação desta oferta, sob a inspiração de Diretrizes Nacionais.

Desta forma, a própria gestão da SEEDUC é responsável por propiciar espaços físicos adequados às práticas educativas, além de adquirir equipamentos e materiais necessários, evitando improvisos e mudanças constantes. A SEEDUC e a SEAP deveriam, em cumprimento às Diretrizes Nacionais, construírem espaços adequados para a oferta de educação, esporte e cultura em cada unidade.

O Colégio possui um corpo docente composto por 14 professores, conforme informação recebida através de consulta pública realizada pelo E-SIC (Protocolo 3187, de 23/10/2018). O corpo técnico administrativo e pedagógico da escola constituído por uma diretora geral e um diretor adjunto, sendo estes servidores concursados pela Secretaria de Estado de Educação ou especificamente para a DIESP.

Conforme o PPP, dentro do espaço escolar atuam monitores, que são apenados que auxiliam o trabalho dos professores e do pessoal de apoio. Nossa pesquisa de campo pôde verificar que os monitores são escolhidos em comum acordo entre a direção e os alunos, entretanto, apesar de trabalharem no ambiente escolar, não são remunerados e não fazem uso do direito da remição de pena pelo trabalho, somente pelo estudo. Não conseguimos identificar durante a pesquisa, nenhum preso que faça uso do direito cumulativo à remição pelo trabalho e pelo estudo.

O Eixo 1 do Projeto Educando para a Liberdade (UNESCO, 2006), estabelece que a remição pela educação deve ser garantida como um direito, de forma paritária com a remição concedida ao trabalho e cumulativa quando envolver a realização paralela das duas atividades. Também orienta que o trabalho prisional seja tomado como elemento de formação e não de exploração de mão-de-obra, garantida a sua oferta em horário e condições compatíveis com as da oferta de estudo. Além de compatível, o trabalho prisional (e todas as demais atividades orientadas à de reintegração social nas Prisões) deve se tornar efetivamente integrado à educação.

O Eixo 2 do Projeto Educando para a Liberdade (UNESCO, 2006), que trata sobre "formação e valorização dos profissionais envolvidos na oferta", define que a pessoa presa, com 
perfil e formação adequados, possa atuar como monitor no processo educativo, recebendo formação continuada condizente com suas práticas pedagógicas, com direito à remição e remuneração.

O PPP afirma que os professores e demais funcionários realizam um trabalho interativo dentro da escola.

\begin{abstract}
Em nossa proposta sintetizamos que não é a aprendizagem que deve se ajustar ao ensino, mas, sim, o ensino que deve potencializar a aprendizagem. Logo, acreditamos que cabe a escola orientar a formação integral do indivíduo, garantindo lhe a aprendizagem com a apropriação de saberes significativos, tornando o capaz de interferir com competência e criticidade na sua própria realidade social. (RIO DE JANEIRO, 2017, p.05)
\end{abstract}

A justificativa do PPP está pautada primeiramente, no direito constitucional à educação, previsto no artigo 205 da CF/88. Também menciona que a LDB ratifica este direito e considera que o acesso ao Ensino Fundamental é um direito público subjetivo, sendo enfático ao citar que "isto significa dizer que o Poder Público pode ser acionado juridicamente para que as pessoas tenham este direito garantido" (RIO DE JANEIRO, 2017, p.06). Contudo, o Projeto não apresenta em sua justificativa, as bases legais que fundamentam a oferta do Ensino Médio nas prisões, obrigatória desde o ano de 2015. Não cita a Educação Superior como possível, conforme previsto nas Diretrizes Nacionais para a oferta de educação para jovens e adultos em situação de privação de liberdade.

O Eixo 1 do Projeto Educando para a Liberdade (UNESCO, 2006), estabelece que os responsáveis pela oferta da educação nas prisões devem elaborar estratégias para a garantia de continuidade de estudos para os egressos, articulando-as com entidades que atuam no apoio dos mesmos, inclusive com universidades.

O PPP se diz seguir as orientações da Constituição Federal e da LDB, apresentando sua proposta pedagógica da seguinte forma:

(...) apresentamos neste documento a proposta pedagógica da instituição prisional José Lewgoy, que baseia seus compromissos de ensino na busca de um aprendizado voltado para a prática e o autoconhecimento, incluindo o desenvolvimento social e emocional dos envolvidos no processo de ensino aprendizagem. (RIO DE JANEIRO, 2017, p. 06, grifo nosso)

Como podemos notar, o termo "instituição prisional” é utilizado para definir o colégio, se distanciando notoriamente dos significados de educação escolar estabelecidos pela própria LDB. Por outro lado, compreendemos que a prisão e a escola se misturam num mesmo contexto, onde 
questões cotidianas decorrentes das relações sociais que acontecem no interior das prisões são levadas para o ambiente escolar e vice-versa. As semelhanças entre ambos os ambientes - escola e prisão - podem ser notadas com relação ao isolamento, na definição de escola proposta por Dayrell (2001).

Um primeiro aspecto, que chama atenção, é o seu isolamento do exterior. Os muros demarcam claramente a passagem entre duas realidades: o mundo da rua e o mundo da escola, como que a tentar separar algo que insiste em se aproximar. A escola tenta se fecharem seu próprio mundo, com suas regras, ritmos e tempos. (DAYRELL, 2001, p. 147)

Outra questão importante é o fato da escola funcionar no espaço adaptado de uma antiga galeria, cujo portão de entrada é uma grade e as salas de aula ocupam as antigas celas.

O PPP, no capítulo destinado as suas justificativas, apresenta o seguinte texto:

(...) embora relativamente antiga no Brasil, sendo objeto de determinação legal ainda nos primórdios da república, a educação prisional tem sido, recentemente, objeto de maior atenção governamental. Iniciativas de organismos federais brasileiros, notadamente das áreas da justiça e da educação, têm ressaltado a importância estratégica do trabalho pedagógico, desde que criativo e de qualidade, além de adequado ao universo do sistema penitenciário.

Ao contrário de simplesmente impedi-los da livre convivência social, se faz necessário que no curso de sua permanência em uma instituição prisional, os presos, especialmente os considerados de baixa periculosidade, participem de programas destinados a impedir sua futura reincidência no crime. Esta, além de perpetuar a condenação de indivíduos a condições existenciais degradantes, reafirmando perversamente os efeitos decorrentes das desigualdades sociais que caracterizam a história de vida de quase toda população carcerária do país, implica na alocação de maiores recursos públicos para a manutenção (e ampliação) dos serviços de segurança e dos complexos presidiários, recursos que poderiam ser mais bem empregados no atendimento de outras demanda s da sociedade, como saúde, educação, geração de emprego, etc.

Entre as iniciativas governamentais existentes, desta se: o Programa Nacional de Seguridade Pública com Cidadania (PRONASCI), o II Seminário Nacional de Consolidação das Diretrizes para a Edu cação no Sistema Penitenciário (realizado em Brasília, em outubro de 2007) e o Projeto Educando para a Liberdade. Todas elas situam como um de seus principais objetivos a ampliação da escolaridade da população carcerária, que em sua maior parte, ou não teve maiores oportunidades de escolarização ou apresenta trajetórias de experiências escolares mal sucedidas. No conjunto, essas iniciativas têm ressaltado a importância de se entender a educação prisional como temática pertinente à educação de adultos e procuram concretizar o disposto em documentos como a Declaração Universal dos Direitos Humanos, a Constituição Federal brasileira, a atual Lei de Diretrizes e Bases da Educação e a Lei de Execução Penal de 1984. (RIO DE JANEIRO, 2017, p. 07)

O trecho em questão, na verdade, é de autoria de Maria Linduina Mendes Maia e Helena Maria da Costa Gomes, publicado no ano de 2014, no artigo "A atuação do psicopedagogo junto ao sistema prisional: ampliando as possibilidades" (GOMES \& MAIA, 2014). O Projeto Político 
Pedagógico do Colégio Estadual José Lewgoy, documento oficial da SEEDUC/RJ, não faz referência as autoras ao copiar parte do artigo.

O Projeto, ao citar que a atual LDB não contempla dispositivos específicos sobre a educação nas prisões, não menciona que a temática é tratada no âmbito da modalidade de EJA. No artigo $4^{\circ}$, a LDB determina que é dever do estado garantir a oferta de educação escolar regular para jovens e adultos, com características e modalidades adequadas às suas necessidades e disponibilidades, conforme é o caso da educação no sistema prisional.

Para o PPP, se faz necessário que “(...) os presos, especialmente os considerados de baixa periculosidade, participem de programas destinados a impedir sua futura reincidência no crime" (RIO DE JANEIRO, 2018, p. 07, grifo nosso). Essa afirmação é contrária ao Eixo 1 do Projeto Educando para a Liberdade (UNESCO, 2006), que estabelece que seja garantido o atendimento diferenciado para pessoas privadas de liberdade no regime fechado, semiaberto, aberto, presos provisórios e em liberdade condicional e aqueles submetidos à medida de segurança, independente de avaliação meritocrática, ou seja, o ensino deve ser garantido da mesma forma a todos, sem tratamento diferenciado aos que são considerados de baixa ou de alta periculosidade.

O PPP cita como iniciativa governamental para a educação nas prisões, o Projeto Educando para a Liberdade (UNESCO, 2006), entretanto, elenca como documentos norteadores do PPP, a Constituição Brasileira, a Declaração Universal dos Direitos Humanos, o disposto nos Parâmetros Curriculares Nacionais (PCN), as Diretrizes Nacionais para a Oferta da Educação em Estabelecimentos Penais (BRASIL, 2010) e a LEP.

Segundo o PPP, a metodologia de ensino do colégio está baseada na proposta humanista, que considera que "o grande projeto da vida é os seres humanos se construírem como cidadãos" (RIO DE JANEIRO, 2018, p. 08). Traz em sua metodologia, o aproveitamento da "religiosidade do alunado para fazê-los evoluir sempre mais" (Ibid, p. 08), contrariando o previsto no Eixo 1 do Projeto Educando para a Liberdade (UNESCO, 2006), que especifica que o atendimento educacional deve contemplar a diversidade, atentando-se para as questões de inclusão, acessibilidade, gênero, etnia, credo, idade e outras correlatas, ou seja, independente da religiosidade (existente ou não), o aluno deve ser capaz de evoluir. ${ }^{71}$

A proposta pedagógica do colégio presente no PPP se constitui em privilegiar o ensino enquanto construção do conhecimento, o desenvolvimento pleno das potencialidades do aluno e

\footnotetext{
${ }^{71}$ Sobre a temática da religião no sistema prisional, ver GAMA (2017).
} 
sua reinserção no ambiente social, entretanto, não define que "ambiente social" é esse. Para atingir o objetivo, são utilizados pelo colégio, os conteúdos curriculares da base nacional comum e os temas transversais, trabalhados em sua contextualização.

A Resolução SEEDUC nº 5666 de 06 de agosto de 2018 fixou diretrizes para a implantação das matrizes curriculares para as unidades escolares prisionais da rede pública do Estado do Rio de Janeiro. As áreas de conhecimento que compõem o currículo são divididas da seguinte forma: I- Linguagens: a) Arte; b) Educação Física; c) Língua Portuguesa; d) Língua Estrangeira moderna; II- Matemática; III- Ciências da Natureza: a) Ciências Biológicas ou Biologia; b) Física, no Ensino Médio; c) Química, no Ensino Médio; IV- Ciências Humanas: a) Filosofia, no Ensino Médio; b) Geografia; c) História;

d) Sociologia, no Ensino Médio; V- Ensino Religioso.

O Ensino Religioso é de oferta obrigatória pela unidade escolar e de matrícula facultativa pelo estudante, nos termos da Lei Estadual no 3459, de 14 de setembro de 2000, e do art. 210 da Constituição Federal.

Os anos iniciais do Ensino Fundamental são ofertados em regime modular, semestral, de modo que as áreas de conhecimento sejam trabalhadas sob a forma de atividades integradas, garantindo-se a interdisciplinaridade e o desenvolvimento do letramento na perspectiva das Diretrizes, Parâmetros e Orientações Curriculares Nacionais e Estaduais. As matrizes das turmas ativas a partir de 2015 são compostas por quatro módulos, sendo necessário, tanto para a conclusão do Ensino Fundamental Anos Iniciais, quanto do Ensino Fundamental Anos Finais, seu cumprimento em totalidade.

O Ensino Médio também é ofertado em regime modular e semestral, cujas matrizes das turmas são compostas por quatro módulos. As matrizes podem ser melhor visualizadas através das tabelas abaixo: 
Tabela 10 - Matriz curricular para os anos iniciais do Ensino Fundamental nas Unidades Escolares Prisionais (2018)

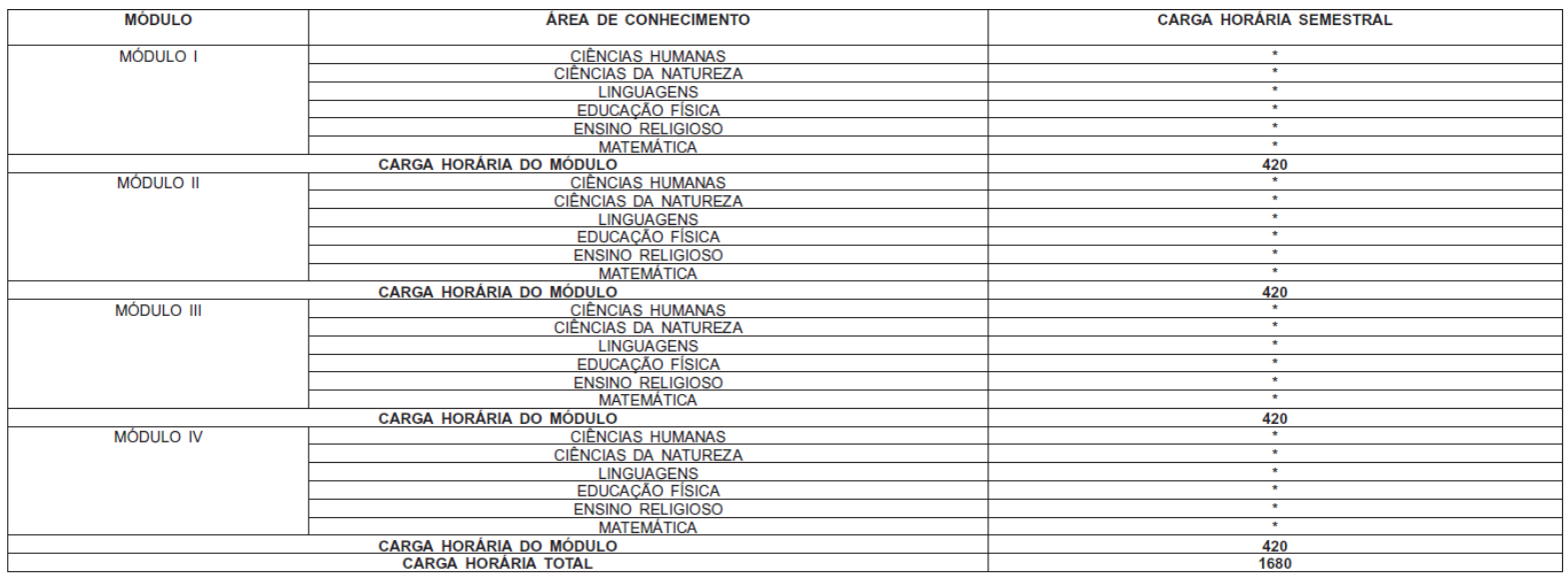

Fonte: Resolução SEEDUC n ${ }^{\circ} 5666$ de 06 de agosto de $2018^{72}$

Tabela 11 - Matriz curricular para os anos finais do Ensino Fundamental nas Unidades Escolares Prisionais (2018)

\begin{tabular}{|c|c|c|c|}
\hline MÓDULO & AREA DE CONHECIMENTO & COMPONENTE CURICULAR & CARGA HORÁRIA SEMESTRAL \\
\hline \multirow[t]{5}{*}{ MÓDULO I } & $\frac{\text { CIÉNCIAS DA NATUREZA }}{\text { MATEMATICA }}$ & $\begin{array}{l}\text { CIĖNCIAS } \\
\text { MATEMATICA }\end{array}$ & $\begin{array}{l}120 \\
80\end{array}$ \\
\hline & ENSINO RELIGIOSO & ENSINO RELIGIOSO & 20 \\
\hline & LINGUAGENS & ARTE & 40 \\
\hline & & $\begin{array}{l}\text { EDUCAÇÃO FISICA } \\
\text { LINGUA ESTRANGEIRA OBRIGATÓRIA }\end{array}$ & $\begin{array}{l}40 \\
40\end{array}$ \\
\hline & & LINGUA PORTUGUESA & 80 \\
\hline \multirow{5}{*}{$\begin{array}{c}\text { CARGA HORARIA DO MÓDULO } \\
\text { MÓDULO II }\end{array}$} & & & 420 \\
\hline & CIĖNCIAS HUMANAS & $\begin{array}{l}\text { GEOGRAFIA } \\
\text { HISTORIA }\end{array}$ & $\begin{array}{l}80 \\
80\end{array}$ \\
\hline & ENSINO RELIGIOSO & ENSINO RELIGIOSO & 20 \\
\hline & LINGUAGENS & IINGUA PORTUGUESA & 120 \\
\hline & MATEMÁTICA & MATEMÁTICA & 120 \\
\hline \multirow{7}{*}{$\begin{array}{l}\text { CARGA HORÁRIA DO MÓDULO } \\
\text { MÓDULO III }\end{array}$} & & & 420 \\
\hline & CIÊNCIAS DA NATUREZA & CIÉNCIAS & 120 \\
\hline & ENSINO RELIGIOSO & ENSINO RELIGIOSO & 20 \\
\hline & LINGUAGENS & $\begin{array}{l}\text { ARTE } \\
\text { EDUCACÃO FISICA }\end{array}$ & $\begin{array}{l}40 \\
40\end{array}$ \\
\hline & & LINGUA ESTRANGEIRA OBRIGATÓRIA & 40 \\
\hline & & LINGUA PORTUGUESA & 80 \\
\hline & MATEMATICA & MATEMATICA & 80 \\
\hline \multirow{5}{*}{$\begin{array}{c}\text { CARGA HORÁRIA DO MÓDULO } \\
\text { MÓDULO IV }\end{array}$} & DVATLIVIATIOA & 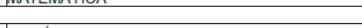 & 420 \\
\hline & CIËNCIAS HUMANAS & HISTÓRIA & 80 \\
\hline & & GEOGRAFIA & 80 \\
\hline & $\begin{array}{l}\text { ENSINO RELIGIOSO } \\
\text { LINGUAGENS }\end{array}$ & $\begin{array}{l}\text { ENSINO RELIGIOSO } \\
\text { LINGUA PORTUGUESA }\end{array}$ & $\begin{array}{c}20 \\
120\end{array}$ \\
\hline & & MATEMÄTICA & 120 \\
\hline \multirow{2}{*}{\multicolumn{3}{|c|}{\begin{tabular}{|l} 
CARGA HORARIA DO MÓDULO \\
CARGA HORARIA TOTAL
\end{tabular}}} & 420 \\
\hline & & & 1680 \\
\hline
\end{tabular}

Fonte: Resolução SEEDUC n ${ }^{\circ} 5666$ de 06 de agosto de $2018^{73}$

${ }^{72}$ Documento fornecido através de consulta pública pelo E-SIC (Protocolo 7138)

${ }^{73}$ Documento fornecido através de consulta pública pelo E-SIC (Protocolo 7138) 
Tabela 12 - Matriz curricular do Ensino Médio nas Unidades Escolares Prisionais (2018)

\begin{tabular}{|c|c|c|c|}
\hline MÓDULO & AREA DE CONHECIMENTO & COMPONENTE CURICULAR & $\begin{array}{l}\text { CARGA HORARIA SEMES- } \\
\text { TRAL }\end{array}$ \\
\hline \multirow[t]{5}{*}{ MÓDULO I } & CIĖNCIAS HUMANAS & FILOSOFIA I & $\frac{40}{80}$ \\
\hline & & $\begin{array}{l}\text { HISTÓRIA I } \\
\text { SOCOOOOGIA }\end{array}$ & 80 \\
\hline & ENSINO RELIGIOSO & ENSINO RELIGIOSO & $\frac{40}{20}$ \\
\hline & LINGUAGENS & LINGUA PORTUGUESA / LITERATURA I & 80 \\
\hline & & & \\
\hline \multirow{4}{*}{$\begin{array}{c}\text { CARGA HORARIA DO MODDULO } \\
\text { MODULO }\end{array}$} & CIĖNCIAS DA NATUREZA & BIOLOGIAI & 80 \\
\hline & & $\begin{array}{l}\text { FISICAI } \\
\text { QUIMICA I }\end{array}$ & $\frac{80}{80}$ \\
\hline & ENSINO RELIGIOSO & ENSINO RELIGIOSO & ñ \\
\hline & $\begin{array}{l}\text { LINGUAGENS } \\
\text { MATEMATICA }\end{array}$ & $\begin{array}{l}\text { LIGUUA PORTGGUESA / LITERATURA I| } \\
\text { MATEMATICA II }\end{array}$ & $\begin{array}{l}80 \\
80\end{array}$ \\
\hline \multirow[t]{6}{*}{$\begin{array}{c}\text { CARGA HORARIA DO MÓDULO } \\
\text { MODDULO III }\end{array}$} & CIENCIAS HUMANAS & FILOSOFIA II & $\frac{420}{40}$ \\
\hline & & GEOGRAFIA II & $\frac{60}{60}$ \\
\hline & (0) & SOCIOLOGIA II & 40 \\
\hline & LINGUAGENS & EDUCAÇAO FISICA & \\
\hline & & LINGUA ESTRANGEIRA OPTATIVA & 40 \\
\hline & MATEMÁTICA & MATEMATICA III & 80 \\
\hline \multirow[t]{5}{*}{$\begin{array}{c}\text { CARGA HORARIA DO MODDULO } \\
\text { MODOULO IV }\end{array}$} & CIÉNCIAS DA NATUREZA & BIOLOGIA II & \\
\hline & & FISICA II & 60 \\
\hline & ENSINO RELIGIOSO & ENSINO RELIGIOSO & 20 \\
\hline & LINGUAGENS & $\begin{array}{l}\text { ATE } \\
\text { LINGUA ESTRANGEIRA }\end{array}$ & \\
\hline & & LINGUA PORTUGUESA / LITERATURA IV & 80 \\
\hline CARGA HORARIA DO MÓDULO & MAIENATICA & & 420 \\
\hline
\end{tabular}

Fonte: Resolução SEEDUC n ${ }^{\circ} 5666$ de 06 de agosto de $2018^{74}$

Em 2019 a SEEDUC implementou o regime semipresencial em cinco unidades escolares como projeto piloto nas turmas de Ensino Fundamental (anos finais) e Ensino Médio. O modelo semipresencial foi criado através da Resolução SEEDUC no 5667, de 10 de agosto de 2018. A Resolução estabelece que $40 \%$ da carga horária dos anos finais do Ensino Fundamental e do Ensino Médio seja cumprida de forma presencial e $60 \%$ a distância, conforme as matrizes curriculares abaixo:

Tabela 13 - Matriz curricular semipresencial para os anos finais do Ensino Fundamental nas Unidades Escolares Prisionais (2018)

\begin{tabular}{|c|c|c|c|c|c|}
\hline MÓDULO & ÁREA DE CONHECIMENTO & COMPONENTE CURICULAR & $\begin{array}{l}\text { CARGA HORÁRIA PRESENCIAL } \\
(40 \%)\end{array}$ & $\begin{array}{c}\text { CARGA HORÁRIA EAD } \\
(60 \%)\end{array}$ & CARGA HORÁRIA SEMESTRAL \\
\hline \multirow[t]{7}{*}{ MÓDULO I } & CIÊNCIAS DA NATUREZA & CIÉNCIAS & * & * & 120 \\
\hline & MATEMÁTICA & MATEMÁTICA & $*$ & $*$ & 80 \\
\hline & ENSINO RELIGIOSO & ENSINO RELIGIOSO & $*$ & * & 20 \\
\hline & EDUCAÇÃO FISICA & EDUCAÇĀO FÍSICA & $*$ & * & 40 \\
\hline & LINGUAGENS & ARTE & $*$ & * & 40 \\
\hline & & LINGUA ESTRANGEIRA OBRIGATÓRIA & $*$ & * & 40 \\
\hline & & LINGUA PORTUGUESA & * & $*$ & 80 \\
\hline \multicolumn{3}{|c|}{ CARGA HORÁRIA DO MÓDULO } & 168 & 252 & 420 \\
\hline \multirow[t]{5}{*}{ MÓDULO II } & CIENNCIAS HUMANAS & GEOGRAFIA & * & $*$ & 80 \\
\hline & & HISTÓRIA & * & * & 80 \\
\hline & ENSINO RELIGIOSO & ENSINO RELIGIOSO & $*$ & $*$ & 20 \\
\hline & LINGUAGENS & LINGUA PORTUGUESA & * & * & 120 \\
\hline & MATEMÁTICA & MATEMÁTICA & $*$ & $*$ & 120 \\
\hline \multicolumn{3}{|c|}{ CARGA HORÁRIA DO MODULLO } & 168 & 252 & 420 \\
\hline \multirow[t]{3}{*}{ MÓDULO III } & CIENNCIAS DA NATUREZA & CIENNCIAS & $*$ & * & 120 \\
\hline & ENSINO RELIGIOSO & ENSINO RELIGIOSO & * & $*$ & 20 \\
\hline & EDUCACCAOO FISICA & EDUCAÇÃO FÍSICA & $*$ & $*$ & 40 \\
\hline
\end{tabular}

\begin{tabular}{|c|c|c|c|c|c|}
\hline & LINGUAGENS & ARTE & * & * & 40 \\
\hline & & LINGUA ESTRANGEIRA OBRIGATÓRIA & \pm & $*$ & 40 \\
\hline & & LINGUA PORTUGUESA & $*$ & * & 80 \\
\hline & MATEMÁTICA & MATEMÁTICA & $*$ & * & 80 \\
\hline CARGA HORÁRIA & & & 168 & 252 & 420 \\
\hline MÓDULO IV & CIENCIAS HUMANAS & HISTÓRIA & $x^{*}$ & $\star$ & 80 \\
\hline & & GEOGRAFIA & * & 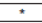 & 80 \\
\hline & ENSINO RELIGIOSO & ENSINO RELIGIOSO & * & * & 20 \\
\hline & LINGUAGENS & LINGUUA PORTUGUESA & * & * & 120 \\
\hline & MATEMÄTICA & MATEMÁTICA & $*$ & $*$ & 120 \\
\hline CARGA HORÁRIA & & & 168 & 252 & 420 \\
\hline & CARGA HORÁ & & 672 & 1008 & 1680 \\
\hline
\end{tabular}

Fonte: Resolução SEEDUC n⿳0 5667 de 10 de agosto de $2018^{75}$

${ }^{74}$ Documento fornecido através de consulta pública pelo E-SIC (Protocolo 7138)

${ }^{75}$ Documento fornecido através de consulta pública pelo E-SIC (Protocolo 7138) 
Tabela 14 - Matriz curricular semipresencial do Ensino Médio nas Unidades Escolares Prisionais (2018)

\begin{tabular}{|c|c|c|c|c|c|}
\hline MÓDULO & AREA DE CONHECIMENTO & COMPONENTE CURICULAR & $\begin{array}{l}\text { CARGA HORÁRIA PRESENCIAL } \\
\qquad(40 \%)\end{array}$ & $\begin{array}{c}\text { CARGA HORÁRIA EAD } \\
(60 \%)\end{array}$ & CARGA HORÁRIA SEMESTRAL \\
\hline \multirow[t]{6}{*}{ MÓDULO I } & CIENCIAS HUMANAS & FILOSOFIA I & * & * & 40 \\
\hline & & GEOGRAFIA I & * & $\cdot$ & 80 \\
\hline & & & $*$ & $\div$ & 80 \\
\hline & & SOCIOLOGIA I & 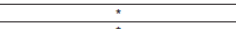 & 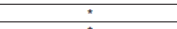 & 40 \\
\hline & ENSINO RELIGIOSO & ENSINO RELIGIOSO & $\div$ & $\div$ & 20 \\
\hline & $\begin{array}{l}\text { LINGUAGENS } \\
\text { MATEMATICA }\end{array}$ & $\begin{array}{l}\text { LINGUA PORTUGUESA / LITERATURA I } \\
\text { MATEMATICA I }\end{array}$ & $\div$ & $\div$ & 80 \\
\hline \multirow{7}{*}{$\begin{array}{c}\text { CARGA HORARIA DO MO } \\
\text { MÓDULO II }\end{array}$} & $\begin{array}{l}\text { MATEMATICA } \\
\end{array}$ & & $\frac{*}{168}$ & $\frac{*}{252}$ & 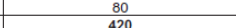 \\
\hline & CIÊNCIAS DA NATUREZA & BIOLOGIA I & & $\frac{202}{*}$ & $\frac{420}{80}$ \\
\hline & & FISICA I I & $*$ & * & 80 \\
\hline & & Química I & * & * & 80 \\
\hline & ENSINO RELIGIOSO & ENSINO RELIGIOSO & $*$ & $*$ & 20 \\
\hline & LINGUAGENS & LINGUA PORTUGUESA / LITERATURA II & $*$ & $*$ & 80 \\
\hline & MATEMÁTICA & |MATEMÁTICA || & & & 80 \\
\hline \multirow{9}{*}{\begin{tabular}{|c|} 
CARGA HORÁRIA DO MÓ \\
MÓDULO III
\end{tabular}} & DULO & & 168 & 252 & 420 \\
\hline & CIENCIAS HUMANAS & $\begin{array}{l}\text { EIIOSOFII } \\
\text { GEOGRAFIA }\end{array}$ & $\div$ & $\div$ & $\frac{40}{60}$ \\
\hline & & HISTORIA II & $*$ & $*$ & 60 \\
\hline & & SOCIOLOGIA II & * & $*$ & 40 \\
\hline & ENSINO RELIGIOSO & ENSINO RELIGIOSO & 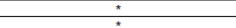 & 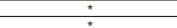 & 20 \\
\hline & $\begin{array}{c}\text { EDUCACÄO FISICA } \\
\text { LINGUAGENS }\end{array}$ & $\begin{array}{l}\text { EDUCACÁO FISICA } \\
\text { LINGUA ESTRANGEIRA OPTATIVA }\end{array}$ & * & * & $\frac{40}{40}$ \\
\hline & & & & & \\
\hline & & LINGUA PORTUGUESA / LITERATURA III & * & $\cdot$ & 80 \\
\hline & MATEMÁTICA & MATEMÁTICA III & \pm & \pm & 80 \\
\hline \multirow{8}{*}{$\begin{array}{c}\text { CARGA HORÁRIA DO MÓ } \\
\text { MÓDULO IV }\end{array}$} & DULO & & 184 & 276 & 460 \\
\hline & CIÊNCIAS DA NATUREZA & BIOLOGIA II & $*$ & 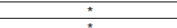 & 60 \\
\hline & & FIIICA \|I & 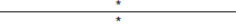 & 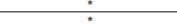 & $\frac{60}{60}$ \\
\hline & ENSINO RELIGIOSO & ENSINO RELIGIOSO & $*$ & $\cdot$ & 20 \\
\hline & LINGUAGENS & ARTE & * & $*$ & 40 \\
\hline & & LINGUA ESTRANGEIRA & $*$ & . & 40 \\
\hline & & LINGUA PORTUGUESA / LITERATURA IV & * & \pm & 80 \\
\hline & MATEMÁTICA & MATEMATICA IV & +5 & .55 & $\frac{60}{420}$ \\
\hline \multicolumn{3}{|c|}{$\begin{array}{l}\text { CARGA HORARIA DO MODULO } \\
\text { CARGA HORARIA TOTAL }\end{array}$} & 688 & 1032 & $\frac{420}{1720}$ \\
\hline
\end{tabular}

Fonte: Resolução SEEDUC nº 5667 de 10 de agosto de $2018^{76}$

O PPP traz em seu texto três metas para o Colégio Estadual José Lewgoy:

1- Garantir educação humanizadora, elevando assim, a autoestima dos nossos alunos;

2- Valorizar o respeito aos direitos humanos e incentivar a exclusão de qualquer tipo de discriminação nas relações interpessoais, públicas e privadas;

3- Realizar parcerias para viabilizar o acesso a cursos de profissionalização ao nosso educando, oferecendo meios para que o mesmo, adquira melhores condições de inserir se no mercado de trabalho. (RIO DE JANEIRO, p. 09)

Neste sentido, a meta 3 cumpre o estabelecido pelo Eixo 1 do Projeto Educando para a Liberdade (UNESCO, 2006) quanto à atribuição da gestão em manter aberta a parcerias com outras áreas de governo, universidades e organizações da sociedade civil, sob a orientação de Diretrizes Nacionais.

O PPP também especifica três diretrizes de ensino:

1- Posicionamento em relação às questões sociais e visão da tarefa educativa como intervenção intencional no presente;

2- Tratamento de valores como conceitos reais, inseridos no contexto do cotidiano;

3- Inclusão dessas perspectivas no ensino dos diversos conteúdos escolares. (Ibid, p. 09)

${ }^{76}$ Documento fornecido através de consulta pública pelo E-SIC (Protocolo 7138) 
Com base nas metas, nas diretrizes de ensino e nos temas transversais preconizados pelos PCNs, o PPP definiu como o seu objetivo geral:

Ser espaço físico, pedagógico, político e cultural de formação de sujeitos, conhecedores e praticantes de plena cidadania e de consciência crítica, capazes de produzir e compartilhar os conhecimentos, transformando-os em aprendizagem concreta e viabilizadora que venha a favorecer o crescimento social dos discentes. (Ibid, p. 10)

São definidos pelo PPP os seguintes objetivos específicos:

- Reconhecer a educação oferecida como um direito instituído por lei;

- Utilizar as dependências da escola de maneira reflexiva;

- Perceber se integrante, dependente e agente transformador do meio ambiente, contribuindo para a melhoria do mesmo;

- Adquirir habilidades para a vida profissional pós-cárcere;

- Em pregar as variadas formas literárias;

- Posicionar-se crítica, responsável e construtivamente nas diversidades, utilizando o diálogo na mediação de conflitos e nas decisões coletivas;

- Adquirir de habilidades de síntese, argumentação e aplicação de conhecimentos;

- Perceber-se parte integrante do meio ambiente e reconhecer a importância da conservação e sustentabilidade do mesmo;

- Resgatar a importância da família, destacando a como primeira instituição na qual fazemos parte e a suma relevância em nos conduzir a uma vida em fraternidade, dotando nos de razão e consciência para agirmos com as outras pessoas com espírito da fraternidade;

- Ressaltar a importância da família, fazendo com que os alunos compreendam que uma família pode nascer a partir de um indivíduo, ainda que o mesmo não tenha participado de uma estrutura familiar;

- Despertar para uma nova consciência, onde cada um é responsável por um futuro melhor, iniciado no presente à medida que perdoam o passado;

- Reformular juízos de valores a partir da vivência no ambiente social;

- Fazer uso de diferentes linguagens para produzir, expressar e transmitir suas ideias;

- Utilizar diferentes fontes de informações para adquirir e construir conhecimentos;

- Compreender direitos e deveres de cidadania;

- Exercer o direito de participar da vida cultural, através de eventos em nossa Unidade Escolar. Com isso promovendo subsídios para a reinserção social.

- Sonhar, partilhando o sonho e as ações para realiza-los;

- Demonstrar atitude de humildade, mas também de autoconfiança;

- Respeitar o meio ambiente, reconhecendo a responsabilidade de deixar recursos naturais necessários para a sobrevivência das gerações futuras.

- Ser autor do seu conhecimento. (Ibid, pp. 10-11)

Dois objetivos específicos versam sobre a família. O primeiro deles pretende resgatar a importância da família, destacando a como primeira instituição na qual fazemos parte, ao passo que o segundo busca ressaltar a importância da família, fazendo com que os alunos compreendam que uma família pode nascer a partir de um indivíduo, ainda que o mesmo não tenha participado 
de uma estrutura familiar. Apesar disto, o Projeto não apresenta caminhos para que os familiares das pessoas privadas de liberdade e a comunidade em geral sejam estimulados, sempre que possível, a acompanhar e a participar de atividades educacionais que contribuam para o processo de reintegração social, conforme orientado pelo Eixo 3 do Projeto Educando para a Liberdade (UNESCO, 2006).

Quanto à avaliação do processo de ensino-aprendizagem, são propostas três formas: 1) prova objetiva valendo de zero a cinco pontos; 2) avaliação formativa através de participação e interesse nos encontros; 3) avaliação através da participação nas oficinas e projetos valendo de zero a três pontos. Diante de um resultado inferior a 50\% (sessenta por cento) nas avaliações, o professor deverá organizar um plano de estudos ou atividades diversificadas para serem realizadas pelo aluno com o objetivo é implementar estratégias alternativas capazes de dinamizar novas oportunidades de aprendizagem.

Sobre a remição de pena, o Projeto informa que todos os internos devidamente matriculados no colégio recebem uma planilha nominal, que é assinada ao término de cada aula, como forma de controle e comprovação de frequência.

Segundo o PPP, desde o ano de 2017, a escola vem participando do processo de remição por leitura, atendendo aos alunos da escola, podendo ser estendido aos internos que não são matriculados. O colégio se incumbe de emprestar livros e fazer as avaliações, de acordo com a lei vigente sobre remição por leitura. Os professores fazem a avalição e aqueles que obtém resultados igual ou superior a 6,0 tem sua avalição enviada ao setor de classificação, que envia para a Vara de Execuções Penais.

Conforme dito anteriormente, optamos por não analisar aqui, o projeto "Memória e letramento: construção da autoria", pois, ao que nos pareceu, este projeto se trata de algo externo ao PPP, que apenas apresenta a importância do letramento na formação do aluno.

O Projeto Político Pedagógico do Colégio José Lewgoy apresenta ao final, três planos de ação em desenvolvimento na unidade escolar. O Projeto de Leitura na Escola e tem por objetivo munir o aluno da consciência e da capacidade que ele tem em construir, dentro das diferentes áreas de conhecimento, sua própria produção textual remontando elementos de sua memória. Outro plano de ação se chama "Literatura no telão" que, apesar de não ser definido pelo PPP, imaginamos tratar-se de apresentação de filmes aos alunos. O terceiro plano diz respeito às "datas históricas e comemorativas", onde são promovidas atividades que envolvam as datas comemorativas dentro 
das áreas específicas de conhecimento contidas nos semestres letivos, trabalhando os temas e suas origens históricas/regionais, destacando as peculiaridades e origem da data e seus desdobramentos históricos e sociais.

Não foi possível avaliar questões importantes presentes nos eixos do Projeto Educando para a Liberdade (UNESCO, 2006), pois estas sequer foram citadas pelo PPP. Sobre isso destacamos a questão do material didático que, durante a pesquisa de campo, verificamos tratarse dos módulos da SEEDUC elaborados para a EJA de forma geral, sem considerar as especificidades da educação nas prisões.

O PPP apresenta traços de incentivo à cultura, entretanto, não menciona se alguma atividade esportiva é desenvolvida pelos alunos. Também não informa se é realizado algum diagnóstico da vida escolar dos apenados logo no seu ingresso ao sistema, com vistas a obter dados para a elaboração de uma proposta educacional que atenda às demandas e circunstâncias de cada um. Neste sentido, descobrimos na pesquisa de campo que, quando o aluno não consegue providenciar seu histórico escolar anterior à prisão, é realizado um exame de nivelamento.

Apesar do PPP mencionar a questão da remição pela leitura, também não especifica se existe uma política de incentivo ao livro e à leitura na unidade, visto que não existe biblioteca e/ou sala de leitura no colégio.

Quanto à formação dos professores, apesar do Projeto não tratar do assunto, durante a pesquisa de campo descobrimos que, ao ingressar no cotidiano do sistema prisional, o professor não passa por nenhum processo de formação promovido pela SEEDUC e/ou pela SEAP.

Durante a análise do Projeto Político Pedagógico do Colégio José Lewgoy sentimos falta de uma construção mais coletiva, que envolva professores, gestores, alunos e demais atores da unidade escolar. Compartilhamos da opinião de Veiga (2007) ao descrever que:

(...)o projeto político-pedagógico exige uma ação colegiada para verificar se as atividades pedagógicas estão coerentes com os objetivos propostos. Exige também que cada professor tenha uma proposta, um plano de ensino articulado ao projeto da escola (VEIGA, 2007, p. 04).

Na escola pública é possível construir uma gestão democrática que constitua caminhos para a melhoria na qualidade e na oferta da educação. Acreditamos que os professores e a gestão do Colégio José Lewgoy são plenamente capazes de formular, em conjunto, um novo Projeto Político 
Pedagógico que contribua para a construção de uma escola que, efetivamente, responda aos interesses de sua coletividade.

\subsection{A experiência docente: diálogos com os professores do Colégio Estadual José Lewgoy}

Será apresentada nesta seção a análise da investigação realizada com seis professores e com a diretora do Colégio Estadual José Lewgoy, professora Lania Regia Alves. Ressaltamos que, por motivo de sigilo, não identificaremos os participantes da pesquisa pelo nome, no entanto, no âmbito da análise dos fragmentos das narrativas, utilizaremos identificaremos cada entrevistado através de números que, no caso dos professores, seguirá do 1 ao 6. A diretora do colégio, devido ao cargo que ocupa, abriu mão do sigilo, portanto, nesse caso em específico, haverá identificação em suas falas.

Conforme já especificamos, todas as entrevistas se deram sem o uso de gravador e, por esse motivo, assumimos que algumas falas acabaram por se perder durante o processo de transcrição, entretanto, não consideramos isso como algo prejudicial aos objetivos propostos nesta etapa da pesquisa.

A entrevista com os professores foi realizada no intervalo destinado ao almoço. A entrevista com a diretora do colégio ocorreu de forma individual em uma das salas de aula da unidade e com todas as interferências externas que o ambiente escolar proporciona em seu dia a dia. A diretora ingressou como professora do Estado no ano de 2000, lecionando a disciplina de Geografia, e possui larga experiência no campo da educação nas prisões.

As respostas às questões apresentadas através dos questionários em anexo, foram unificadas por temas para facilitar o entendimento e pelo fato de que, na entrevista em grupo, ocorreu uma discussão coletiva onde nem todos os participantes opinaram sobre determinados assuntos. Após a computação dos dados, optamos por unificar algumas perguntas tendo em vista que as respostas se complementam e facilitam a compreensão da temática abordada.

As dificuldades do pesquisador em realizar entrevistas no campo da educação nas prisões do Estado do Rio de Janeiro foram relatadas em diversos estudos. Merecem destaque as teses de doutorado de Vieira (2014) e de Souza (2017), além da dissertação de mestrado de Braz (2016), que retratam, especificamente, sobre os entraves encontrados nas entrevistas realizadas com professores, devido aos horários de funcionamento das escolas, à dinâmica de suas rotinas em 
outros colégios e à movimentação decorrente da rotina em sala de aula; fatores que devem ser considerados também nessa pesquisa.

O primeiro tema levantado na entrevista em grupo e na entrevista com a direção foi a capacitação e a formação. Neste sentido, realizamos a seguinte pergunta: Você recebeu alguma formação específica para trabalhar como professor no ambiente prisional? Todos os professores responderam que não receberam formação alguma.

Os professores 1 e 2 abordaram a questão da formação e da rigidez por parte da SEAP com relação ao ingresso dos docentes na unidade.

Não recebi nenhum treinamento quando cheguei na DIESP. Fiquei sabendo por uma amiga que deveria usar um jaleco branco. Imaginei que não pudesse entrar com celular, mas ninguém me avisou nada antes. Não sabia se podia usar relógio, brinco. Aprendi tudo com a prática. (PROFESSOR 1)

Formação não recebemos, mas enviaram pra gente um manual de conduta sobre como se comportar. Fizeram a gente assinar um termo nos comprometendo a cumprir todas as regras. (PROFESSOR 2)

O uso de um jaleco branco foi determinado pela SEAP, entretanto, não nos foi informado o motivo. O "manual de conduta" especificado pelo professor 2 se trata do Termo do Convênio $\mathrm{n}^{\circ}$ 17/2017 firmado entre a SEAP e a SEEDUC, especificado no capítulo anterior.

Ainda sobre a formação docente, percebemos que os professores gostariam que fossem realizados treinamentos e/ou encontros que pudessem tratar das especificidades da educação nas prisões. Ao responder essa mesma pergunta, a diretora esclareceu que, apesar de não existir formação específica, ela orienta os professores quando chegam ao colégio. Relatou que já participou de seminários organizados pela SEEDUC sobre a temática, mas esses seminários deixaram de acontecer.

Sobre o exercício da atividade docente nas prisões, Vieira (2008) relata que se faz necessária uma formação constante que ofereça subsídios para o enfrentamento das situações de trabalho.

Podemos afirmar que as condições do exercício da atividade docente na prisão são diretamente influenciadas pelo clima da cadeia, pelas normas que regem o dia-a-dia no cárcere e por serem os objetivos da educação variados e complexos, requerem do profissional um nível maior de autonomia, responsabilidade, envolvimento pessoal, formação constante a fim de oferecer-lhes subsídios para o enfrentamento diário das situações de trabalho. É preciso que os professores interpretem, ressignifiquem e adaptem 
constantemente tais objetivos aos contextos movediços da prática pedagógica (VIEIRA, 2008, p.08).

Especificamente sobre a formação dos professores que atuam nas prisões do Rio de Janeiro, em 2017, Souza já havia feito a seguinte sugestão:

Por fim, sugiro a construção de uma política pública voltada para a formação dos professores, estes atores sociais que atuam no sistema prisional, de maneira a formá-los e capacitá-los para a sua vivência no espaço da prisão, assim esses profissionais terão um maior embasamento teórico metodológico em suas ações educativas.

Nesse sentido, esse professor terá as ferramentas pedagógicas necessárias para a sua melhor atuação e levando a um melhor rendimento do aluno/preso. (SOUZA, 2017, p. 195)

O segundo eixo do Projeto Educando para a Liberdade (UNESCO, 2006) estabelece que o professor, ao ingressar no cotidiano prisional, deve passar por um processo de formação promovido pela pasta responsável pela Administração Penitenciária em parceria com a da Educação, no qual a educação nas prisões seja tratada conforme os marcos da política penitenciária nacional. Além disso, o mesmo eixo orienta que a formação continuada dos profissionais que atuam no sistema penitenciário ocorra de maneira integrada, envolvendo diferentes áreas, como trabalho, saúde, educação, esportes, cultura, segurança, assistência psicossocial e demais áreas de interesse, de modo a contribuir para a melhor compreensão do tratamento penal e aprimoramento das diferentes funções de cada segmento.

Já o primeiro eixo do projeto versa sobre a promoção de encontros regionais e nacionais sobre a Educação nas Prisões envolvendo todos os atores relevantes, em especial Diretores de Unidades Prisionais e do Setor de Ensino, tendo como um dos itens de pauta a troca de experiências.

A maioria dos professores que trabalha no colégio também leciona fora da prisão, inclusive a diretora, que é servidora da SEEDUC e da Prefeitura do Rio de Janeiro. Desta forma, foi possível traçar um paralelo entre os dois ambientes escolares: dentro e fora da prisão. Ao responderem a pergunta "Para você há diferença em lecionar dentro ou fora da prisão?", os professores comentaram:

Existe uma diferença enorme. Hoje em dia, lá fora, não existe mais aluno que respeite o professor. Temos muito mais problemas para nos preocupar do que aqui dentro. E aluno usando o celular o tempo todo em sala de aula. Nossa! Só de não ter celular aqui já é um alívio enorme. (PROFESSOR 1) 
Existe uma diferença com relação a aula, né?! Aqui a rotatividade é grande, principalmente por ser semiaberto. Hoje mesmo eu tive que dar a mesma aula da semana passada porque a turma já mudou. Alguns tinham faltado. A gente precisa se adaptar muito mais aqui, mas eu não reclamo. Adoro dar aula aqui. Tenho paz e tranquilidade que não vejo lá fora. (PROFESSOR 3)

Não é a mesma coisa. É muito melhor. Os alunos são mais atenciosos, prestam mais atenção a aula. (PROFESSOR 4)

Eu confesso que entrei aqui pela gratificação. É muito fácil pedir transferência para uma escola da DIESP. É só demonstrar interesse que te transferem. Agora não quero saber de dar aula em outro tipo de escola. Me sinto respeitado aqui. (PROFESSOR 5)

Existe uma grande diferença entre as duas escolas. Os alunos daqui são mais dedicados ao estudo. Se esforçam mais. Eu não tenho problemas com eles. São muito prestativos também. (DIRETORA)

Os relatos apresentados se complementam entre si e se relacionam com questões relatadas na análise do PEEP e do PPP do colégio. Os professores, de forma geral, se sentem desvalorizados pelos alunos em ambientes externos à prisão. Apesar do professor 5 ter escolhido trabalhar no colégio devido à gratificação especial recebida pela especificidade da questão, conforme já relatamos, essa gratificação não sofre reajuste desde o ano de 2008, ou seja, hoje em dia esse motivo não possui muita relevância, visto que, no decorrer de nossa pesquisa, a escola estava com o déficit de uma vaga de professor.

A questão trazida pelo professor 3 sobre a rotatividade e esporádicas ausências dos alunos também é algo que atrapalha o planejamento de aula, entretanto, existe uma boa vontade por parte dos professores em readaptar as aulas de forma a aplicar os conteúdos exigidos. Sobre esse aspecto, a diretora comentou em sua entrevista:

Algumas atividades são desenvolvidas por parte da SEAP nos horários de aula e os alunos acabam faltando. Existe um período do ano que fazem campeonato de futebol. Como não temos quadra no colégio e não podemos oferecer esportes, os alunos faltam as aulas durante todo o campeonato. (DIRETORA)

Conforme especificado no primeiro eixo do Projeto Educando para a Liberdade (UNESCO, 2006), as autoridades responsáveis pela gestão devem transformar a escola num espaço integrado às rotinas da unidade prisional e da execução penal, com a inclusão de suas atividades no plano de segurança adotado, ou seja, na situação apresentada pela diretora caberia a SEAP articular as atividades esportivas em conjunto com a direção do colégio, de forma integrada e sem prejudicar a frequência escolar. 
Os professores, quando perguntados se conhecem as Diretrizes Nacionais para a Oferta da Educação em Estabelecimentos Penais, responderam que sim, mas que não possuem um conhecimento aprofundado sobre o documento. Também disseram que não perceberam nenhuma mudança na educação em prisões a partir da aprovação das Diretrizes.

Quanto ao Plano Estadual de Educação em Prisões e sobre o currículo do Estado para a educação em prisões, os professores responderam que têm conhecimento sobre ambos os documentos, mas não participaram da elaboração de nenhum deles.

Sobre o assunto, fizeram algumas críticas quanto à matriz curricular e ao material didático. Desta forma, optamos por tratar da seguinte pergunta: Você acha que o currículo e o material didático fornecido pela SEEDUC é adequado para a Educação em Prisões? Por que?.

Eu utilizo o livro na minha disciplina. Acho bom. (PROFESSOR 1)

Eu quase não uso o livro. Os conteúdos da minha disciplina são muito corridos. Os alunos daqui não conseguem acompanhar essa dinâmica rápida de ensino. Eu tenho que ir devagar senão eles não aprendem. (PROFESSOR 5)

Utilizamos os livros da EJA fornecidos pela SEEDUC. Nenhum deles é específico para o público das escolas prisionais. (PROFESSOR 6)

O material poderia ser mais adequado. (DIRETORA)

Como podemos perceber, a questão da utilização do material didático em sala de aula divide opiniões, onde os professores acreditam ser bom para determinadas disciplinas e ruim para outras. Nesse momento, indagamos sobre a elaboração de um material didático específico para a educação nas prisões e todos acreditaram ser uma boa sugestão, desde que esse material fosse elaborado através de uma consulta aos profissionais que atuam nas unidades escolares prisionais.

Como a modalidade semipresencial entrou em fase de testes no início de 2019, conforme apresentado pela SEEDUC através de consulta pública, não foi possível nos aprofundarmos sobre essa questão com os internos. Contudo, apresentamos aqui as opiniões dos docentes sobre o assunto, apesar da modalidade ainda não existir no Colégio Estadual José Lewgoy.

Na pergunta Como você vê a possibilidade do ensino a distância no sistema prisional?, obtemos as respostas que seguem.

Agora estão implementando os módulos semipresenciais. Eu, particularmente, sou contra. Nas celas eles não conseguem estudar. (PROFESSOR 5) 
Se colocarem a faculdade pode até funcionar, mas eu duvido muito que isso aconteça. (PROFESSOR 3)

A modalidade semipresencial, no meu ponto de vista, trará mais matrículas para a SEEDUC e menos certificações. Falta disciplina no interno para estudar sozinho. As celas são muito movimentadas, com gente falando o tempo todo. Fica difícil estudar lá. (DIRETORA)

As interferências do ambiente prisional novamente são citadas pelos professores em suas falas. Devido aos impactos da superlotação prisional o aluno preso tem dificuldades para estudar em suas celas, isso porque, muitas vezes não dormem ou não conseguem o silêncio necessário para a concentração nos estudos.

Perguntamos aos professores como eles avaliam as condições da Educação nas prisões do Rio de Janeiro. Fomos respondidos da seguinte forma:

Poderia ser bem maior. Muita gente quer estudar. Tem gente que não sabe nem que tem escola aqui. (PROFESSORA 1)

Se tivessem mais vagas precisaríamos de mais professores. De forma geral, a oferta não é boa. Não existem escolas em todos os presídios. Deve ter muito mais gente querendo estudar e não consegue. (PROFESSORA 2)

Eu acho a oferta boa para o nosso colégio porque não cabe mais aluno ali. As salas são pequenas. (PROFESSORA 3)

Pro nosso colégio também acho a quantidade boa. Poderiam construir outros colégios aqui ou aumentar o nosso. (PROFESSORA 4)

$\mathrm{Eu}$ acho que os internos sabem que a escola existe e que eles podem estudar. Pode ser falta de interesse mesmo. Mas se a escola tivesse mais vagas e fosse feita uma campanha de matrículas, poderíamos atingir um público maior, mas isso iria depender de mais espaço e de mais professores. (PROFESSOR 5)

A oferta é muito menor, considerando o público que poderia ser atingido. (DIRETORA)

Conforme já mencionamos anteriormente, a oferta da educação no Estado do Rio de Janeiro funciona de forma precária, considerando o número de matrículas e o quantitativo de detentos. $\mathrm{Na}$ ocasião da pesquisa de campo tomamos conhecimento de que já existiu uma tentativa de ampliação do Colégio Estadual José Lewgoy, entretanto, esta não foi autorizada pela SEAP.

Os professores entrevistados informaram que não recebem nenhum apoio por parte das universidades. Por parte da SEEDUC, o apoio é dado somente através da diretora. Perguntamos também, como é tratado o professor da educação em prisões na estrutura da carreira do magistério no Estado do Rio de Janeiro. Os professores responderam que são tratados de forma 
igual a qualquer outro professor da SEEDUC. Nesse momento surgiram as reclamações quanto ao reajuste da gratificação.

Acho uma vergonha essa gratificação. Um coordenador educacional ganhar $\mathrm{R} \$ 350$. Ninguém quer correr esse risco só por isso. (PROFESSOR 2)

A SEEDUC precisa aumentar essa gratificação. Precisa valorizar os professores. (PROFESSOR 5)

Nossa gratificação está sem reajuste desde 2008. Nunca foi reajustada até hoje. (DIRETORA)

Por fim, perguntamos qual é o papel da educação em prisões.

É um trabalho muito gratificante. A gente vê a diferença que o nosso trabalho faz na vida dessas pessoas. (PROFESSORA 1)

Aqui dentro o professor se sente muito mais valorizado porque dá pra ver o resultado do nosso trabalho. Existe uma troca, sabe?! (PROFESSORA 2)

Quando a gente trabalha com esse tipo de aluno verificamos a importância da educação para essas pessoas. Me faz pensar nos motivos que me fizeram escolher essa profissão. Mesmo com as dificuldades, é muito gratificante o nosso trabalho aqui. (PROFESSORA 3)

A educação possibilita o resgate do ser humano. Serve para potencializar a autoestima e a valorização de si mesmo. A educação tem o papel de mostrar aos alunos que existem outras possibilidades. Entregar o diploma para um aluno que está saindo em liberdade é muito gratificante. (DIRETORA)

Analisando os discursos dos docentes de forma geral, percebemos existir uma espécie de tensão na fala dos professores ao lembrarem de situações vivenciadas em outras escolas fora da prisão. Desta forma, foi possível verificamos que lecionar no Colégio Estadual José Lewgoy perpassa pelo prazer e pela realização pessoal do professor, que se sente valorizado nesse espaço educacional.

\subsection{O aluno do Colégio Estadual José Lewgoy}

Será apresentada nesta seção a análise da investigação realizada com cinco alunos do Colégio Estadual José Lewgoy. Ressaltamos novamente que, por motivo de sigilo, não identificaremos os participantes da pesquisa pelo nome, no entanto, no âmbito da análise dos 
fragmentos das narrativas, utilizaremos identificaremos cada entrevistado através de números que, no caso dos alunos, seguirá do 1 ao 5.

Organizamos por meio da tabela abaixo, o perfil dos entrevistados.

Tabela 15 - Perfil dos alunos entrevistados

\begin{tabular}{|c|l|l|l|c|c|}
\hline Entrevistado & Idade & Cor & $\begin{array}{l}\text { Ano de } \\
\text { ingresso na } \\
\text { prisão }\end{array}$ & $\begin{array}{c}\text { Grau de } \\
\text { escolaridade } \\
\text { inicial }\end{array}$ & $\begin{array}{c}\text { Grau de } \\
\text { escolaridade } \\
\text { atual }\end{array}$ \\
\hline Aluno 1 & 28 anos & Negro & 2009 & $\begin{array}{c}\text { Ensino } \\
\text { Fundamental } \\
\text { incompleto } \\
\text { (anos finais) }\end{array}$ & $\begin{array}{c}\text { Ensino médio } \\
\text { incompleto }\end{array}$ \\
\hline Aluno 2 & 35 anos & Branco & 2004 & $\begin{array}{c}\text { Ensino } \\
\text { Fundamental } \\
\text { incompleto } \\
\text { (anos iniciais) }\end{array}$ & $\begin{array}{c}\text { Ensino médio } \\
\text { incompleto }\end{array}$ \\
\hline Aluno 3 & 34 anos & Branco & 2004 & $\begin{array}{c}\text { Ensino } \\
\text { Fundamental } \\
\text { incompleto } \\
\text { (anos iniciais) }\end{array}$ & $\begin{array}{c}\text { Ensino } \\
\text { Fundamental } \\
\text { incompleto } \\
\text { (anos iniciais) }\end{array}$ \\
\hline Aluno 4 & 46 anos & Branco & 2016 & $\begin{array}{c}\text { Não possuía } \\
\text { Fundamental } \\
\text { incompleto }\end{array}$ \\
\hline Aluno 5 & 43 anos & Negro & 1994 & $\begin{array}{c}\text { Fundamental } \\
\text { incompleto } \\
\text { (anos iniciais) }\end{array}$ & $\begin{array}{c}\text { Fundamental } \\
\text { incompleto } \\
\text { (anos finais) }\end{array}$ \\
\hline
\end{tabular}

Optamos por entrevistar alunos com graus de escolaridade diversos, sendo pelo menos um de cada módulo (ensino médio, anos iniciais e anos finais do ensino fundamental). Com as perguntas Por que decidiu voltar a estudar? e Quais são os seus objetivos estudando?, obtemos as seguintes respostas:

Por que decidiu voltar a estudar?

Para aprimorar os conhecimentos, ter um diploma e poder arrumar um emprego quando sair daqui. (ALUNO 1)

Por causa da minha família. (ALUNO 2)

Para recuperar o tempo perdido. (ALUNO 3) 
Devido às dificuldades fora da prisão. Preciso ter uma profissão. (ALUNO 4)

O estudo é importante para melhorar a vida. Poder arrumar um emprego com um bom salário. (ALUNO 5)

\section{Quais são os seus objetivos estudando?}

Fazer faculdade de Educação Física. (ALUNO 1)

Fazer Veterinária ou Nutrição. (ALUNO 2)

Aprender mais e poder escrever. (ALUNO 3)

Dar continuidade lá fora. Cursar Engenharia Mecânica. (ALUNO 4)

Trabalhar. Cursar Psicologia e por em prática um projeto com dependentes químicos. (ALUNO 5)

O ambiente escolar favorece lembranças e o resgate da memória. Segundo Vieira (2014), a memória é um instrumento reflexivo adquirido pelo homem diante da essência do esquecimento, que ajuda a perceber um comprometimento do ser humano com o futuro, a partir de fatos passados.

Podemos verificar a existência de um resgate da memória nas falas dos alunos entrevistados, ao tratar da "família", do "tempo perdido" e das "dificuldades fora da prisão". Também existe uma preocupação com o futuro nas falas, suprimida diante da esperança de poder ter um diploma e arrumar um emprego após sair da prisão.

Percebemos que existe na maioria dos entrevistados um desejo em cursar faculdade, entretanto, conforme já mencionamos, não existe educação superior nas prisões do Estado do Rio de Janeiro e esse direito não é garantido às pessoas privadas de liberdade.

Quatro dos alunos entrevistados ficaram sabendo da existência da escola na prisão através de seus colegas de cela. Um deles disse que foi informado quando entrou no sistema prisional. Esse fato demonstra a pouca divulgação da escola por parte da SEAP e da SEEDUC aos indivíduos que ingressam nas prisões, fator contrário ao disposto no Projeto Educando para a Liberdade (UNESCO, 2006) e nas Diretrizes Nacionais para a Oferta da Educação em Estabelecimentos Penais.

Ao serem perguntados sobre suas participações em atividades artísticas, esportivas, culturais e religiosas, três alunos informaram que participam dos cultos realizados na prisão. Um deles não participa de nenhuma atividade e o outro está envolvido em atividades artísticas, quando propostas pela escola. 
Todos os entrevistados disseram que não exercem nenhum tipo de trabalho na prisão. Os alunos 1 e 2 são monitores no colégio, mas não veem essa função como um trabalho. Conforme dito anteriormente, apesar de trabalharem no ambiente escolar, não são remunerados e não fazem uso do direito da remição de pena pelo trabalho, somente pelo estudo.

Perguntados sobre a preferência entre estudar, trabalhar ou fazer os dois, todos os entrevistados disseram que preferem estudar. Na sequência fizemos a seguinte pergunta: Você recebe dos inspetores penitenciários algum incentivo ou apoio para estudar?

\author{
Nenhum. Não temos diálogo. (ALUNO 1) \\ Não. Até somos discriminados por eles. (ALUNO 2) \\ Não. Eles só abrem e fecham o portão. (ALUNO 3) \\ Não temos contato com eles. (ALUNO 4) \\ Não, mas eu vejo no olhar dos inspetores que, quando alguém está estudando, eles ficam \\ felizes. (ALUNO 5)
}

Nas observações em campo percebemos um problema que atinge o colégio: a diminuição do tempo do aluno em sala de aula devido à demora na liberação desses por parte dos inspetores. Eles também são responsáveis pela abertura e pelo fechamento da grade da escola. Desta forma, vivenciamos junto aos professores uma demora considerável para a abertura das grades no início das aulas, no intervalo e durante a saída, fato este que ocorre diariamente. Com isso, no nosso ponto de vista, os inspetores, em sua maioria, precisam de esclarecimentos por parte da SEEDUC quanto a sua importância no processo educacional.

Perguntamos com qual profissional o aluno se relaciona melhor na prisão e todos responderam que a relação é melhor com os professores. Quando perguntados sobre como avaliam as condições de oferta da educação na prisão em termos de infraestrutura, sala de aula, horários, material pedagógico e currículo, responderam:

O tratamento é ótimo. Aqui você esquece que está preso. A escola é pequena, possui poucas salas. Não tem quadras, biblioteca, sala de leitura. O livro é bom e os horários também. (ALUNO 1)

A infraestrutura é precária. O educador não é reconhecido. Temos pouco tempo de aula. (ALUNO 2)

O horário está bom. Dá pra melhorar a quantidade de salas. (ALUNO 3) 
Está legal mas pode melhorar. Se tivesse mais salas teríamos mais vagas. (ALUNO 4)

A estrutura é boa mas pode melhorar com ajuda do governo para ampliação da escola. É preciso que o governo escute os professores e a diretora. (ALUNO 5)

Diante da superlotação carcerária que encontram em suas celas, a maioria dos alunos acha o espaço escolar bom, entretanto, carece de ampliação.

Sobre o aspecto do espaço físico, notamos durante a pesquisa de campo, que o corredor externo às salas de aula não possui ar condicionado ou ventilador, e os espaços das salas, por serem adaptados, apresentam problemas acústicos. Entretanto, de forma geral, o espaço da escola é bem cuidado, limpo e organizado.

Nos incomodamos com o fato dos alunos pouco conversarem entre si, além de não circulares pela escola. Longe do que se espera de um espaço escolar que se preocupa em oportunizar o diálogo entre os atores envolvidos, é nítida a contenção dos movimentos, postura típica do ambiente prisional.

Os entrevistados foram perguntados se estudam, discutem a matéria e leem livros quando não estão no ambiente escolar. Um deles disse que não, e os quatro restantes informaram que apenas leem livros, inclusive a Bíblia.

Quando perguntados se consideram a educação na prisão como um direito ou um privilégio, responderam:

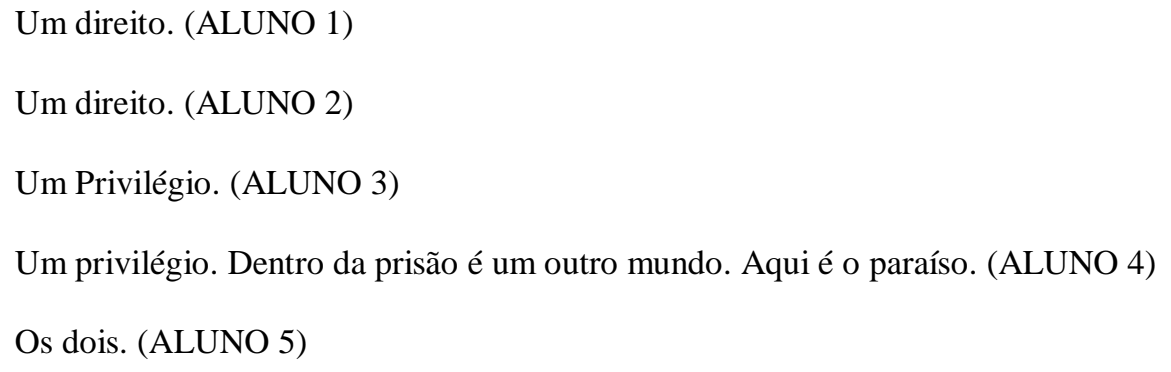

Os entrevistados não conhecem o Plano Estadual de Educação em Prisões mas sabem da existência de um convênio entre a SEAP e a SEEDUC que propiciou o exercício do direito à educação nas prisões do Estado do Rio de Janeiro.

Diante das entrevistas realizadas com os alunos no espaço prisional, percebemos algumas representações decorrentes da educação, que geralmente não são registradas em documento oficiais, existindo apenas na memória dos atores que ali se produzem. Neste sentido, o Colégio 
Estadual José Lewgoy, construído enquanto um lugar de memória, tem suas narrativas e experiências registradas por meio desta tese. 


\section{CONSIDERAÇÕES FINAIS}

(...) não há ensino sem pesquisa e pesquisa sem ensino (...) ensino porque busco, porque indaguei, porque indago e me indago. Pesquiso para constatar, constatando, intervenho, intervindo educo e me educo. Pesquiso para conhecer o que não conheço e comunicar ou anunciar a novidade. (FREIRE, 1996, p. 32)

Durante a realização desta pesquisa nos deparamos com muitos limites e desafios que revelaram as dificuldades encontradas pelo pesquisador no ambiente prisional. Por outro lado, os caminhos aqui percorridos nos fizeram construir novos saberes a partir da teoria e da prática da produção acadêmica, através do diálogo constante com a coletividade ou mesmo reflexivo e individual. Tendo como base as palavras de Paulo Freire (1996), constatamos a importância da pesquisa para a formação do professor, no sentido de este compreender a si mesmo e ao ambiente que o rodeia.

Retomamos, então, com o objetivo da pesquisa aqui desenvolvida: investigar a efetiva capacidade das prisões do Estado do Rio de Janeiro em promover, garantir e defender o direito à educação das pessoas privadas de liberdade sob sua responsabilidade, tendo como marco referencial os princípios e as orientações emanadas das Diretrizes Nacionais para a oferta da Educação (BRASIL, 2010) em estabelecimentos penais, cujo propósito é a institucionalização da educação em prisões como parte constituinte da política educacional brasileira.

Com isso surgiram alguns questionamentos iniciais: Quais são as ações que têm sido tomadas pelo Estado do Rio de Janeiro no sentido de assegurar o direito à educação de sua população prisional? Como a educação escolar está configurada nos presídios cariocas? Qual é o papel que a educação exerce no processo de reintegração social, considerando a realidade das prisões do Estado do Rio de Janeiro?

Neste sentido, podemos confirmar através deste estudo de caso, que a oferta da educação no sistema prisional do Estado do Rio de Janeiro convive com problemas crônicos de diferentes ordens, como, por exemplo, as estruturas precárias (ou a falta delas), o descaso do poder público e o preconceito da sociedade. São inúmeros os aspectos que dificultam a compreensão e a implementação de processos educacionais mais conectados a uma visão emancipadora de educação que a considere como um direito humano.

Apesar de todo o legado de leis, normas e documentos analisados e que visam garantir os direitos dos cidadãos privados de liberdade, muitas dessas propostas legais não têm sido aplicadas 
pelos Estados. Sobre o arcabouço legal do próprio Estado do Rio de Janeiro, seu Plano Estadual de Educação e o Plano Estadual de Educação em Prisões, que norteia as práticas educativas nas prisões estaduais, estes, por sua vez, também carecem de uma reformulação e, principalmente, de seu cumprimento.

Gostaríamos de destacar também que o acesso restrito aos documentos e a burocracia imputada pelo Estado do Rio de Janeiro aos pesquisadores dificultaram muito o andamento desta pesquisa. Os problemas relatados identificam a necessidade de uma sensibilização maior por parte do Estado no sentido de tornar públicos seus documentos e o acesso a eles, em cumprimento a Lei de Acesso a Informação.

De acordo com as entrevistas e os relatos ouvidos durante a pesquisa de campo no Colégio Estadual José Lewgoy, percebemos que existem múltiplos significados e valores que são atribuídos à educação nas prisões, entretanto, o significado predominante é o de "mudança de vida". Aplicar e praticar este princípio num espaço onde a estrutura é precária, se torna cada vez mais difícil. Assim, a educação muitas vezes é vista como canal de conquista a determinados benefícios, e não como um direito de todos.

Apesar dos problemas encontrados, consideramos que o Colégio Estadual José Lewgoy em suas práticas tem contribuído para saberes e fazeres pedagógicos diferenciados, que possibilitem compreensões possíveis dos reais fatores capazes de cumprir as funções sociais da escola, mesmo que na prisão.

Contudo, nos cabe lembrar o perfil das pessoas privadas de liberdade no Brasil: jovens, negros, pobres e com baixa escolaridade; ou seja, anterior ao "comportamento desviante" que os leva à prisão, a escola, se frequentada por eles, deixou de cumprir o seu papel formador, não garantiu uma formação capaz de permitir o ingresso ao mercado de trabalho e deixou de compartilhar regras de convivência em sociedade.

Vista a necessidade da educação na prisão se constituir de maneira diferente da escola extramuros, elencaremos alguns limites e possibilidades desse campo no âmbito do Estado do Rio de Janeiro, considerando os aspectos históricos, legais e sociais analisados até aqui.

Segundo Silva (2010), a atual política pública adotada no Brasil permite abordar a educação como dever do Estado e como direito do cidadão, onde, como dever do Estado, se relaciona à obrigatoriedade da garantia da oferta de Educação e, como direito do cidadão, corresponde, por parte deste, ao exercício da condição de sujeito de direitos. 
Cabe destacar que os limites impostos à educação, nas prisões ou fora delas, nos remete a um campo de luta e não simplesmente à um meio reprodutor de práticas naturalizadas. Como vimos ao longo desta tese, a dinâmica da escola na prisão possibilita a tessitura de movimentos capazes de acabar ou pelo menos diminuir as práticas excludentes.

A educação escolar desempenha um importante papel nas sociedades modernas como espaço de socialização e de construção de uma sociedade melhor e mais justa, entretanto, para Silva (2010), a escola exerce hoje as funções educativas básicas atribuídas à família e se constitui como principal instrumento para a execução de políticas sociais e setoriais a partir de três pilares: a inclusão social, a formação para a cidadania e a redução das desigualdades sociais. Esse cenário, segundo o autor, exige uma melhor instrumentação da escola pública para dar conta de suas crescentes tarefas, ou seja, é necessário pensar em seu reordenamento. Neste sentido, aponta três possibilidades para o desencadeamento desse processo: 1) por iniciativa da escola; 2) por iniciativa dos sistemas municipais e estaduais de ensino; 3) por iniciativa dos conselhos estaduais e municipais de Educação.

Qualquer que seja a via escolhida para proceder ao reordenamento das escolas públicas, há que se considerar a necessidade de revisão dos estatutos e dos regimentos internos da escola e de suas instituições auxiliares, tanto para eliminar o excesso de centralismo que ainda permeia a organização dos sistemas de ensino, como para redefinir o papel e a função das instituições auxiliares da escola. (SILVA, 2010, p.80)

Ao mergulharmos no cotidiano educacional das prisões percebemos a necessidade de um reordenamento da escola pública também nesse campo. Podemos citar como exemplo a análise do Projeto Político Pedagógico do Colégio Estadual José Lewgoy que nos fez perceber a necessidade imediata de reconstrução do documento, de forma coletiva e com a participação de todos os atores envolvidos. Provavelmente essa é uma necessidade que perpassa por toda a rede estadual de ensino.

Apesar de carecer de formação específica e de uma maior valorização, o trabalho docente realizado no contexto escolar das prisões se apresenta como uma possibilidade de superar a ideia da educação prisional como uma simples ferramenta de "ressocialização". Através da figura do professor, os alunos, no lugar de se "ressocializarem", se reinventam diariamente.

Outro fator relevante é a questão do espaço físico da escola. Mesmo com a obrigatoriedade da assistência educacional, os espaços escolares no Estado do Rio de Janeiro são, em sua grande 
maioria, adaptados. Sobre a temática, recentemente o CNPCP, através da Resolução nº 6, de 7 de dezembro de 2017, estabeleceu uma flexibilização nas Diretrizes Básicas para Arquitetura Penal, excluindo os módulos de educação e de trabalho.

Mesmo diante deste limite é necessário que exista uma mobilização maior para que se consiga ampliar a estrutura física do colégio de modo a possibilitar o atendimento à mais alunos. Um exemplo de que essa mobilização é possível, consta na tese de doutorado de José Paulo de Morais Souza intitulada A escola na prisão: uma abordagem crítica sob a ótica do profissional em educação. Souza (2017) relata a respeito da ampliação do Colégio Anacleto de Medeiros, localizado no Presídio Evaristo de Moraes, que ocorreu após um longo processo de negociação entre a SEAP e a SEEDUC.

O Colégio Anacleto de Medeiros teve o seu início como uma sala improvisada, autorizada pelo diretor do presídio à época, com uma turma de alfabetização, no ano de 1970, chegando ao ensino médio na atualidade. O colégio passou por diversas mudanças, algumas estruturais, considerando os espaços que foram ampliados em face às conquistas da direção do colégio, junto à direção do estabelecimento prisional, um processo de negociação sempre longo e de súplica por espaço para ampliar o ensino. Identificamos que o colégio passou por um processo contínuo de conquista dos espaços e se fez ouvir, mesmo que de maneira modesta, no sistema prisional. (SOUZA, 2017, p. 186-187)

Também se faz necessário que o Estado coloque em prática o que é previsto pelas Diretrizes Nacionais para a oferta de educação para jovens e adultos em situação de privação de liberdade nos estabelecimentos penais (BRASIL, 2010b), no sentido de proporcionar a oferta à educação em todos os turnos, inclusive no noturno.

Acreditamos na importância da interlocução da SEEDUC com grupos de pesquisa nacionais e internacionais, com o objetivo de auxiliar na melhoria da oferta do ensino nas prisões do Estado. Sobre esse viés destacamos as experiências do Grupo de estudio sobre Educación en Cárceles-GESEC, localizado na cidade de La Plata, em Buenos Aires/Argentina, da Rede Latinoamericana de Educação em Espaços de Privação de Liberdade ${ }^{77}$ e do Grupo de Estudos e Pesquisas sobre Educação em Regimes de Privação da Liberdade (GEPÊPrivação), da Universidade de São Paulo.

Diante dos limites e das possibilidades apresentadas entendemos que existe um longo caminho a ser percorrido pelo Estado do Rio de Janeiro no sentido de viabilizar uma educação que

\footnotetext{
77 Sobre a experiência da Rede Latinoamericana de Educação em Espaços de Privação de Liberdade, ver Julião \& Rita (2008).
} 
atinja todos os níveis de ensino e seja disponibilizada a todos os que se encontram em situação de privação de liberdade. Entretanto, verificamos com as análises desenvolvidas ao longo dos capítulos desta tese, que é possível cumprir as Diretrizes Nacionais para a oferta da Educação em estabelecimentos penais (BRASIL, 2010) e também os eixos estabelecidos pelo Projeto Educando para a Liberdade (UNESCO, 2006).

Muito aprendemos ao longo dos anos destinados a esta pesquisa, mas reafirmamos, como no texto introdutório, em reconhecer este trabalho como uma construção social inacabada, sendo sua linha de interpretação considerada apenas como uma possibilidade entre tantas outras possíveis, no entanto, servindo como um ponto de partida para que futuras análises nos ofereçam novos olhares. 


\section{REFERÊNCIAS BIBLIOGRÁFICAS}

ADORNO, Sérgio. Sistema penitenciário no Brasil. Revista USP, 1991.

Discriminação racial e justiça criminal em São Paulo. In: $19^{\circ}$ Encontro Anual da ANPOCS. Novos estudos, n. 43, 1995.

Racismo, Criminalidade Violenta e Justiça Penal: Réus Brancos e Negros Em Perspectiva Comparativa. Estudos Históricos, Rio de Janeiro, v. 9, n.18, p. 283-300, 1996.

AGUIRRE, Carlos. Cárcere e sociedade na América Latina 1800-1940. in. MAIA, C. [et al.] História das Prisões no Brasil, v.1. Rio de Janeiro: Rocco, 2009.

ANDRÉ, Marli. O que é um estudo de caso qualitativo em Educação. Revista da FEEBA Educação e Contemporaneidade, Salvador, v.22,n.40, jul./dez., 2013. p.95-103.

ARAÚJO, C.E.M. Entre dois cativeiros: escravidão urbana e sistema prisional no Rio de Janeiro 1790-1821. In. História das Prisões no Brasil. vol. 1. MAIA, C.estudoN. ... [et al.] Rio de Janeiro: Rocco, 2009.

ARROYO, Miguel González. Ofício do Mestre. Petrópolis: Vozes, 2003.

Educação de jovens e adultos: um campo de direitos e de responsabilidade pública. In: SOARES, Leôncio; GIOVANETTI, Maria Amélia G. C.; GOMES, Nilma Lino (orgs.). Diálogos na educação de jovens e adultos. Belo Horizonte: Autêntica, 2005. p. 19- 50.

BARATTA, Alessandro. Ressocialização ou controle social: uma abordagem crítica da "reintegração social" do sentenciado. Universidade de Saarland, 1990. Disponível em <http://danielafeli.dominiotemporario.com/doc/ALESSANDRO\%20BARATTA\%20Ressocializ acao\%20ou\%20controle\%20social.pdf>. Acesso em: 02 jun. 2019.

BECCARIA, Cesare. Dos Delitos e das Penas. São Paulo: Martin Claret, 2001.

BEUMONT, G. \& TOCQUeVILle, A. de. On the Penitentiary System in the United States and Its Application in France. Trad. Francis Lieber. Filadélfia, 1833.

BOGDAN, Robert. \& BIKLEN, Sari. Investigação qualitativa em educação. Porto: Porto Editora, 1994.

BRAGA, Ana Gabriela Mendes. Reintegração social: discursos e práticas na prisão - um estudo comparado. Tese de Doutorado em Direito - Faculdade de Direito da Universidade de São Paulo, São Paulo: 2012.

BRANDAO, Carlos Rodrigues. Reflexões de como fazer trabalho de campo. Sociedade e Cultura, V. 10, N. 1, Jan./Jun. 2007, p. 11-27.

BRASIL. Constituição Política do Império do Brasil, elaborada por um Conselho de Estado e outorgada pelo Imperador D. Pedro I, em 25.03.1824. Disponível em: <http://www.planalto.gov.br/ccivil_03/constituicao/constituicao24.htm>. Acesso em: 03 set. 2019. 
Decreto $\mathrm{n}^{\mathbf{0}}$ 1.441, de 8 de Fevereiro de 1937. Disponível em <https://www2.camara.leg.br/legin/fed/decret/1930-1939/decreto-1441-8-fevereiro-1937458648-publicacaooriginal-1-pe.html> Acesso em: 03 abr. 2019.

Lei 7.210, de 11.06.1984. Lei de Execução Penal (LEP, 1984). Disponível em: http://www.planalto.gov.br. Acesso em: 10 ago. 2017.

Lei de Diretrizes e Bases da Educação Nacional. Lei 9394, de 20 de dezembro de 1996. Disponível em: 〈http://www.planalto.gov.br/ccivil_03/LEIS/L9394.htm〉. Acesso em: 19 set. 2019.

. Plano Nacional de Educação. Lei 10.172, de 09 de janeiro de 2001. Disponível em: <http://portal.mec.gov.br/arquivos/pdf/L10172.pdf〉. Acesso em: 25 set. 2019.

. Plano Nacional de Educação. Lei 13.005/2014, de 25 de junho de 2014. Disponível em: <http://www.planalto.gov.br/ccivil_03/_ato2011-2014/2014/lei/l13005.htm>. Acesso em: 18 jan. 2020.

_. Programa Nacional de Direitos Humanos. Decreto $\mathbf{n}^{0}$ 7.037, de 21 de dezembro de $2009 . \quad$ Disponível em: <http://www.planalto.gov.br/ccivil_03/_Ato20072010/2009/Decreto/D7037.htm\#art7>. Acesso em: 14 set. 2019.

Relatório sobre as Diretrizes Nacionais para a oferta de educação para jovens e adultos em situação de privação de liberdade nos estabelecimentos penais. Relator: Adeum Hilário Sauer. Conselho Nacional de Educação. Brasília: 2010a. Disponível em: $<$ http://portal.mec.gov.br/index.php?option=com_docman\&view $=\quad$ download\&alias $=4445$ pceb004-10\&category_slug=abril-2010-pdf\&Itemid=30192 >. Acesso em: 08 out. 2019.

. Conselho Nacional de Educação (CNE). Câmara de Educação Básica (CEB). Resolução $\mathbf{n}^{\circ}$ 2, de 19 de maio de 2010. Dispõe sobre as Diretrizes Nacionais para a oferta de educação para jovens e adultos em situação de privação de liberdade nos estabelecimentos penais. Diário Oficial da União, Seção 1, p. 20, 20 de maio de 2010. Brasília: 2010b. Disponível em: < http://portal.mec.gov.br/index.php?option=com_docman\&view=download\&alias=5142-rceb00210\&category_slug=maio-2010-pdf\&Itemid=30192>. Acesso em: 08 out. 2019.

Lei $\mathbf{n}^{\circ}$ 9.394, de 20 de dezembro de 1996. Estabelece Lei de Diretrizes e Bases da Educação Nacional (LDB). Disponível em: BRASIL. Lei ${ }^{\circ}$ 12.433, de 29 de junho de 2011. Altera a Lei no 7.210, de 11 de julho de 1984 (Lei de Execução Penal), para dispor sobre a remição de parte do tempo de execução da pena por estudo ou por trabalho. Diário Oficial da União, Brasília, 30 de jun. de 2011.

Conselho Nacional de Política Criminal e Penitenciária (Cnpcp). Resolução no 3, de 11 de março de 2009. Dispõe sobre as Diretrizes Nacionais para a Oferta de Educação nos Estabelecimentos penais. Diário Oficial da União, Brasília, Seção 1, p. 22, 25 mar. 2009. Brasília, v. 24, n. $86, \quad$ p. 89-103, nov. 2011. Disponível em <http://portal.mec.gov.br/index.php?option=com_docman\&view=download\&alias=5142rceb002-10\&category_slug=maio-2010-pdf\&Itemid=30192> Acesso em: 27 mai. 2019. 
Ministério da Educação. Secretaria de Educação Básica. Secretaria de Educação Continuada, Alfabetização, Diversidade e Inclusão. Conselho Nacional da Educação. Diretrizes Curriculares Nacionais Gerais da Educação Básica. Ministério da Educação. Secretaria de Educação Básica. Diretoria de Currículos e Educação Integral. Brasília: MEC, SEB, DICEI, 2013. Disponível em: <http://portal.mec.gov.br/docman/julho-2013-pdf/13677-diretrizes-educacaobasica-2013-pdf/file>. Acesso em: 08 out. 2019.

Levantamento Nacional de Informações Penitenciárias - INFOPEN - Dezembro de 2014. Brasília: Ministério da Justiça e Segurança Pública, Departamento Penitenciário Nacional DEPEN, 2015. Disponível em < http://depen.gov.br/DEPEN/depen/sisdepen/infopen/relatoriossinteticos/copy_of_infopen_dez14.pdf>. Acesso em: 03 abr. 2019.

Levantamento Nacional de Informações Penitenciárias - INFOPEN - Junho de 2016. Brasília: Ministério da Justiça e Segurança Pública, Departamento Penitenciário Nacional DEPEN, 2017. Disponível em < http://depen.gov.br/DEPEN/depen/sisdepen/infopen/relatoriossinteticos/relatorio_2016_2211.pdf>. Acesso em: 05 dez. 2018.

BRAZ, J.M.O. Memórias e construções subjetivas nos espaços escolares prisionais: apropriação e transformação docente. Dissertação de Mestrado, Universidade Federal do Estado do Rio de Janeiro, UNIRIO. Rio de Janeiro: 2016.

BRETAS, MAIA, COSTA \& NETO. Introdução: História e historiografia das prisões. in. MAIA, C. [et al.] História das Prisões no Brasil, v.1. Rio de Janeiro: Rocco, 2009.

CARRILlO, Affonso Torres. A educação popular como prática política e pedagógica emancipadora. In: STRECK, Danilo \& ESTEBAN, Maria Teresa (orgs.). Educação Popular: lugar de construção social coletiva. Petrópolis, Editora Vozes: 2013.

CARVALHO, Odair França de. Entre a cela e a sala de aula: um estudo sobre experiências educacionais de educadores presos no sistema prisional paulista. Tese de doutorado. Universidade Federal de Uberlândia, Programa de Pós-graduação em Educação. São Paulo: 2014.

CEDERJ. Educação superior a distância em Gericinó. Fundação Cecierj: Rio de Janeiro, 2017. Disponível em: http://cederj.edu.br/fundacao/educacao-superior-a-distancia-dentro-de-gericino/. Acesso em 02 ago. 2017.

CERVO, Amado L.; BERVIAN, Pedro A.; SILVA, Roberto da. Metodologia científica. 6. ed. São Paulo: Pearson Prentice Hall, 2007.

CESAR, Tiago da Silva. A ilusão panóptica: encarcerar e punir nas imperiais cadeias da província de São Pedro.. In: XI Encontro Estadual de História - História, memória e patrimônio, p. 1122-1137. Rio Grande do Sul: 2012.

Estado, sociedade e o nascimento da prisão na América Latina. Revista Métis: História \& Cultura, v.12, n.23. Rio Grande do Sul: UCS, 2013. p.32-48.

CHAZKEL, Amy. Uma perigosíssima lição: a Casa de Detenção do Rio de Janeiro na Primeira República. In. MAIA, C.N. et al. (org.). História das prisões no Brasil, vl.2. Rio de Janeiro: Rocco, 2009. p. 07-45 
COELHO, Edmundo Campos. A administração da justiça criminal no Rio de Janeiro. in Dados, nº 29 - 1, Rio de Janeiro: IUPERJ, 1986.

COSTA, Marcos Paulo Pedrosa. O caos ressurgira da ordem: Fernando de Noronha e a reforma prisional do Império. Dissertação de Mestrado, Universidade Federal da Paraíba: UFPB, 2007.

CRUZ NETO, O.; MOREIRA, M. R.; SUCENA, L. F. M. Grupos focais e pesquisa social qualitativa: o debate orientado como técnica de investigação. In: ENCONTRO DA ASSOCIAÇÃO BRASILEIRA DE ESTUDOS POPULACIONAIS, ABEP. Minas Gerais: 2002.

CURY, Carlos Roberto Jamil. Reforma universitária na nova Lei de Diretrizes e Bases da Educação Nacional. In. Cadernos de Pesquisa, n.101, p.3-19, jul. 1997.

Direito à Educação: direito à igualdade, direito à diferença. In. Cadernos de Pesquisa, n. 116, p. 245-262, jul. 2002.

DAYRELL, Juarez. Múltiplos olhares sobre educação e cultura. Editora UFMG, 2001.

DI PIERRO, M. C. Balanço e perspectivas da pesquisa sobre formação de educadores/as de jovens e adultos. In: III Seminário Nacional Formação de educadores de educação de jovens e adultos, 2011, Porto Alegre. Formação de educadores de educação de jovens e adultos: anais. Porto Alegre: Deriva, 2010. p. 166-177.

DIEHLL, Astor. \& TATIM, Denise. Pesquisa em ciências sociais aplicadas: métodos e técnicas. São Paulo. Pearson Prentice Hall, 2004.

DOURADO, Luiz Fernandes. Avaliação do Plano Nacional de Educação 2001-2009: questões estruturais e conjunturais de uma política. Educ. Soc., Campinas, v. 31, n. 112, p. 677-705, jul.set. 2010. Disponível em: <http://www.scielo.br/pdf/es/v31n112/03.pdf>. Acesso em: 28 set. 2019.

ESTEBAN, José Ortega. Pedagogía Social y Pedagogía Escolar: la educación social en la escuela. Revista de Educación, núm. 336, 2005, pp. 111-127.

FAVERO, Osmar; MOTTA, Elisa. Educação Popular I, II e Educação de Jovens e Adultos. Petrópolis: DP\&A e FAPERJ, 2016.

FANTINATO, Maria Cecília \& DE VARGAS, Sônia Maria. Formação de professores da educação de jovens e adultos: diversidade, diálogo, autonomia. Rev. Diálogo Educ., Curitiba, v. 11, n. 34, p. 915-931, set./dez. 2011.

FOUCAULT, Michel. Vigiar e Punir: nascimento da prisão. Petrópolis: Vozes, 1ª edição, 1975. Microfísica do Poder. 16 ${ }^{\mathrm{a}}$ ed. Rio de Janeiro: Graal. 2001.

A hermenêutica do sujeito. São Paulo: Martins Fontes, 2002.

Vigiar e Punir: nascimento da prisão. Petrópolis, Vozes, 9a edição, 2008. 
FREIRE, Paulo. Educação como prática de liberdade. Rio de Janeiro: Paz e Terra, 1979.

Pedagogia dos sonhos possíveis. Ana Maria Araújo Freire (org.). São Paulo: Editora Unesp, 2001.

. Pedagogia da Autonomia: saberes necessários à prática educativa. 30 ed. São Paulo, Paz e Terra, 2004.

. Pedagogia do oprimido. $63^{\mathrm{a}}$ ed. Rio de Janeiro: Paz e Terra, 2017.

GADOTTI, Moacir. Perspectivas atuais da educação. Porto Alegre: Artes Médicas, 2000.

GAMA, Taíza da Silva. Religião e sistema prisional: um estudo sobre a assistência religiosa pentecostal no processo de reintegração da população carcerária do Estado do Rio de Janeiro. 1.Ed. Ananindeua: Editora Itacaiúnas, 2017.

GOFFMAN, Erwing. A representação do eu na vida cotidiana. Petrópolis, Vozes, 2002.

Manicômios, Prisões e Conventos. 8ª ed. São Paulo: Editora Perspectiva, 2013.

GOMES, H.M.C. \& MAIA, M. L. M. A atuação do psicopedagogo junto ao sistema prisional: ampliando as possibilidades. In: CONPEDI. (Org.). A Humanização do Direito e a Horizontalização da Justiça no século XXI. XXIed.SANTA CATARINA: CONPEDI, 2014, v., p. $127-145$

Disponível em: <http://webcache.googleusercontent.com/search?q=cache:QnszkwJmL88J:www.publicadireito.c om.br/artigos $/ \% 3$ Fcod\%3Db681006b27581d53+\&cd=1\&hl=pt-BR\&ct=clnk\&gl=br $>. \quad$ Acesso em: 12 out. 2019.

GOODE, W. J.; HATT, P. K. Métodos em pesquisa social. São Paulo: Nacional, 1979.

GRAMSCI, Antonio. Quaderni del carcere. Turim: Einaudi, 1975.

1982.

. Os intelectuais e a organização da cultura. $4^{\mathrm{a}}$ ed. Rio de Janeiro: Civilização Brasileira,

GREENWOOD, E. Los Métodos de Investigación Empírica en Sociologia. Revista Mexicana de Sociologia, vol. XXV, n. ${ }^{\circ}$ 2, de Maio-Agosto, 1963.

HADDAD, Sérgio (coord.). Educação de jovens e adultos no Brasil (1986-1998). Brasília-DF: MEC/Inep/Comped, 2002, 140p.

IRELAND, T.D. Educação de Jovens e Adultos como política pública no Brasil (2004-2010): os desafios da desigualdade e diversidade. Rizoma Freireano, v. 13, p. 93-110, 2012.

JULIÃO, E. Política pública de Educação Penitenciária: contribuição para o diagnóstico da experiência do Rio de Janeiro. Dissertação de Mestrado, Faculdade de Educação PUC/RJ, 2003.

Ressocialização através da educação e do trabalho no Sistema Penitenciário

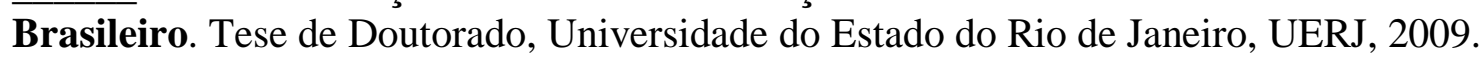


Educação para jovens e adultos em situação de restrição e privação de liberdade no Brasil: questões teóricas, políticas e pedagógicas. Belo Horizonte, UFMG, 2016.

JULIÃO, E. \& ONOFRE, E. Educação em Prisões. Educação \& Realidade, Porto Alegre, v. 38, n. 1, p. 11-14, jan./mar. 2013.

JULIÃO, E. F.; RITA, R. P. S. Rede Latinoamericana de Educação em Espaços de Privação de Liberdade: uma estratégia de intercâmbio e consolidação de Políticas Públicas para a execução penal. Revista do Conselho Nacional de Politica Criminal e Penitenciaria, v. 1, p. 2948, 2008.

KANNO, Massato. Estudo sobre modelos de Ensino a Distância para Apenados. Trabalho de conclusão do curso de Graduação em Ciência da Computação. Universidade Estadual de Londrina, Centro de Ciências Exatas. Londrina: 2013. Disponível em: < www.uel.br/cce/dc/wpcontent/uploads/TCC-MassatoKanno-BCC-UEL-2013.pdf>. Acesso em: 09 out. 2019.

LAKATOS, Eva Maria. \& MARCONI, Marina de Andrade. Fundamentos de metodologia científica - 5. ed. - São Paulo: Atlas 2003.

LEME, José Antonio Gonçalves. A cela de aula: tirando a pena com letras. Uma reflexão sobre o sentido da educação nos presídios. Dissertação de Mestrado, Programa de Pós-Graduação em Educação. São Paulo: PUC, 2002.

MAIA, C.; NETO, F.; COSTA, M \& BRETAS, M. L. História das prisões no Brasil. v. 01. Rio de Janeiro: Rocco, 2009.

História das prisões no Brasil. v. 02. Rio de Janeiro: Rocco, 2009.

MARX, Karl \& ENGELS, Friedrich. O Manifesto comunista. 5a ed. São Paulo: Paz e Terra, 1999.

MALINOWSKI, Bronislaw. Objetivo método e alcance desta pesquisa. In:. Guimarães, Zaluar Alba. Desvendando mascaras social. Rio de Janeiro: Livraria Francisco Alves Editora S. A. $2^{\text {a }}$ Ed. 1980.

MARTINS, Heloisa H. T. de Souza. Metodologia qualitativa de pesquisa Educação e

Pesquisa. São Paulo, Universidade de São Paulo. v.30, n.2, p. 289-300, maio/ago, 2004.

MAXIMILIANO, Carlos. Hermenêutica e aplicação do direito. São Paulo: Revista Forense, 1999 (1924).

MELOSSI, D. \& PAVARINI, M. Cárcere e Fábrica - As origens do sistema penitenciário (séculos XVI-XIX). Rio de Janeiro: Renan: ICC, 2006. $2^{\text {a }}$ ed, 2010.

NATORP, Paul. Sozialpädagogik. Theorie der Willenbildung auf der Grundlage der Gemeinschaft. Stuttgart: Frommanns, 1899.

NETO \& PINHEIRO. Programa Nacional de Direitos Humanos: avaliação do primeiro ano e perspectivas. Revista Estudos Avançados. v.11 n. 30, pp. 117-134. São Paulo: 1997. 
OLIVEIRA, Carolina Bessa Ferreira de. Universidade pública na prisão: desafios para além da pesquisa acadêmica. pp. 54-73. Aracê - Direitos Humanos em Revista, Ano 4, Número 5, $2017 \mathrm{a}$.

A educação nas prisões brasileiras: a responsabilidade da universidade pública. Tese de Doutorado em Educação. Faculdade de Educação da Universidade de São Paulo. São Paulo: 2017b. Disponível em: <http://www.teses.usp.br/teses/disponiveis/48/48134/tde-31102017111844/pt-br.php>. Acesso em: 09 out. 2019.

OLIVEIRA, Edmundo. O futuro alternativo das prisões. Editora Forense, Rio de Janeiro 2002.

ONOFRE, Elenice Maria Cammarosano. Educação escolar na prisão. Para além das grades: a essência da escola e a possibilidade de resgate da identidade do homem aprisionado. (Tese de Doutorado). Faculdade de Ciências e Letras. Araraquara: UNESP, 2002.

. O exercício da docência em espaços de privação de liberdade. Comunicações, Ano 18, n. 2. jul.-dez., 2011. Piracicaba: 2011, p. 37-46.

ONU, Declaração Universal dos Direitos Humanos das Nações Unidas, 1948. Disponível em: <https://declaracao1948.com.br/declaracao-universal/declaracao/>. Acesso em:03 set. 2019.

PAIVA, Jane. A construção coletiva da política de educação de jovens e adultos no Brasil. In: MACHADO, Maria Margarida (org.). Educação de Jovens e Adultos. Em Aberto / Instituto Nacional de Estudos e Pesquisas Educacionais Anísio Teixeira. v. 1, n. 1, (nov. 1981 - ). - Brasília: INEP, 2009.

PAIVA, MACHADO \& IRELAND (org.). Educação de Jovens e Adultos: uma memória contemporânea, 1996-2004. Secretaria de Educação Continuada, Alfabetização e Diversidade do Ministério da Educação: Organização das Nações Unidas para a Educação, a Ciência e a Cultura. Brasília: 2007.

PARDO, Paulo et al. EAD como ferramenta transformadora de vidas: $O$ caso da penitenciária estadual de Maringá. In: CONGRESSO INTERNACIONAL DE EDUCAÇÃO A DISTANCIA, 2011, Manaus: ABED, 2011.p. 1 - 10. Disponível em: 〈http://www.abed.org.br/congresso2011/>. Acesso em: 09 out. 2019.

PEREIRA, Antonio. A educação de jovens e adultos no sistema prisional brasileiro: o que dizem os planos estaduais de educação em prisões? Revista Tempos e Espaços em Educação, São Cristóvão, Sergipe, Brasil, v. 11, n. 24, p. 217-252, jan./mar. 2018. Disponível em: <http://dx.doi.org/10.20952/revtee.v11i24.6657> Acesso em: 07 out. 2019.

PINEL, Hiran; COLODETE, Paulo Roque; PAIVA, Jacyara Silva. Pedagogia Social: definições, formação, espaços de trabalho, grandes nomes \& epistemologias. Conhec. Dest., Serra, ES, v. 01, n. 02, jul./dez. 2012.

RAMALHO, José R. Mundo do crime: a ordem pelo avesso. Rio de Janeiro: Graal. 1979.

RIO DE JANEIRO. Decreto Estadual nº 8897: Regulamento do Sistema Penal do Estado do Rio de Janeiro. Rio de Janeiro: 1986. 
. Plano Estadual de Educação. Rio de Janeiro: SEEDUC, 2009.

- Projeto Político Pedagógico do Colégio Estadual José Lewgoy: "Memória e letramento: construção da autoria” - triênio 2017-2019. Rio de Janeiro: SEEDUC, 2017.

. Plano Estadual de Educação em Prisões. Rio de Janeiro: SEEDUC, 2018.

RIBEIRO, V. M. Breve histórico da educação de jovens e adultos no Brasil. In: RIBEIRO, Vera Maria Masagão (org.) Educação de jovens e adultos: Proposta curricular para o $1^{\circ}$ segmento do ensino fundamental. São Paulo: Ação Educativa; Brasília: MEC, 1997.

Referências internacionais sobre avaliação da educação de jovens e adultos. In: CATELLI JR. et al (Orgs.). A EJA em xeque: desafios das políticas de educação de jovens e adultos no século XXI. São Paulo, Global/Ação Educativa, 2014, p. 17-38.

SALLA, Fernando. As prisões em São Paulo (1822-1940). São Paulo: Annablume, 1999.

Os impasses da democracia brasileira: o balanço de uma década de políticas para as prisões no Brasil. Lusitopie: Brasil, 2003.

SANT'ANNA, M. A. Trabalho e conflitos na Casa de Correção do Rio de Janeiro. In: Maia, Clarissa N.; Sá Neto, Flávio de; Costa, Marcos; Bretas, Marcos. (Org.). História das Prisões no Brasil. Rio de Janeiro: Rocco, 2009.

SANTOS, J. J. R. Especificidades dos saberes para a docência na educação de pessoas jovens e adultas. Práxis educacional v.6, n.8 (pp.157-176) jan/jun 2010.

SILVA, R., NETO, J.C.S. \& MOURA, R. (orgs.). Pedagogia Social. São Paulo: Expressão e Arte Editora, vol. 1. $3^{\text {a }}$ edição, 2014.

SILVA, R.; \& MOREIRA, F. A. O projeto político-pedagógico para a educação em prisões. In. Revista Em Aberto, INEP, Brasília, v. 24, n. 86, pp. 89-103, nov. 2011.

SILVA, Roberto da. A eficácia sócio-pedagógica da pena de privação da liberdade. São Paulo: Feusp (tese de doutoramento), 2001.

A Pedagogia Social em construção no Brasil. Porto: Revista Portuguesa de Investigação Educacional. 2009. V. 8, série 1, pp. 148-162 15.

. Limites e possibilidades do direito à educação na legislação educacional brasileira. Voos - Revista Polidisciplinar Eletrônica da Faculdade Guairacá. vol.2. ed. 01. Caderno de Ciências Humanas. Paraná: 2010.

. Educação em Prisões: apontamentos para um Projeto Político Pedagógico. Congr. Intern. Pedagogia Social, 2012.

. Os fundamentos freirianos da Pedagogia Social em construção no Brasil. Pedagogía Social. Revista Interuniversitaria, 2016, 27, pp. 179-198.

Formação de professores para espaços não escolares e a regulamentação da Educação Social como profissão no Brasil. In: Milka Helena Carrilho Slavez; João Antonio de 
Souza. (Org.). Formação de professores no Brasil: tendências, cenários e aspectos culturais. 1ed.São Carlos: Pedro e João Editores, 2018, v. 1, p. 17-42.

SOUZA, J. P. M. A escola na prisão: uma abordagem crítica sob a ótica do profissional em educação. Tese de Doutorado em Memória Social. Universidade Federal do Estado do Rio de Janeiro, UNIRIO. Rio de Janeiro: 2017.

SOUZA, Laura Guedes de. Análise jurídica do sistema penitenciário brasileiro à luz dos Tratados Internacionais em Direitos Humanos. Revista Direito em Ação, Brasília, v. 14, n. 1, p. 1-21, jan./jun.2015.

SOUZA NETO, João Clemente. $O$ educador social em espaços de aprendizagem não escolar. In: ANDRADE, M. S; BARONE, L. C. M. Aprendizagem contextualizada. São Paulo: Casa do Psicólogo, 2013. p. 57-58.

STAKE, Robert E. Estudos de Caso em pesquisa e avaliação educacional. Educação e Seleção, São Paulo, n. 7, 1983. p. 5-14.

UNESCO. Educando para a liberdade: trajetória, debates e proposições de um projeto para a educação nas prisões brasileiras. Brasília: Unesco, Governo Japonês, Ministério da Educação, Ministério da Justiça, 2006.

VASCONCELOS, Ana Silvia Furtado. A saúde sob custódia: um estudo sobre agentes de segurança penitenciária no Rio de Janeiro. Fundação Oswaldo Cruz, Escola Nacional de Saúde Pública. Rio de Janeiro, 2000. 66 f. Mestrado (mestrado em Saúde Pública) - Fundação Oswaldo Cruz, Rio de Janeiro, 2000.

VAZ, Sérgio. Colecionador de Pedras. São Paulo: Global, 2013.

VEIGA, I. P. A. Projeto Político-Pedagógico, Conselho Escolar e Conselho de Classe: instrumentos da organização do trabalho. In: XXIII Simpósio Brasileiro, V Congresso LusoBrasileiro, I Colóquio Ibero-Americano de políticas e administração da educação. Porto Alegre: ANPAE, 2007.

VIEIRA, Elizabeth de Lima Gil. Trabalho Docente: de portas abertas para o cotidiano de uma escola prisional. Dissertação de Mestrado em Educação. PUC/RJ. 2008.

A construção da memória da cultura escolar prisional: uma análise do espaço, das práticas pedagógicas e das interações no Colégio Estadual Mário Quintana. Universidade Federal do Estado do Rio de Janeiro, UNIRIO, 2014.

XAVIER, L. N.; GOMES, A. C. ; HANSEN, P. S. ; FARIA FILHO, L. M. ; PINTASILGO, J. . Interfaces entre a história da educação e a história social e política dos intelectuais: conceitos, questões e apropriações. In: GOMES, Ângela de Castro e HANSEN, Patrícia dos Santos. (Org.). Intelectuais Mediadores: práticas culturais e ação política. 1ed., Rio de Janeiro: Civilização Brasileira, 2016. p. 464-486. 
ANEXOS 


\section{A. Roteiro de entrevistas}

\section{QUESTIONÁRIO}

\section{PESQUISA DE DOUTORADO: LIMITES E POSSIBILIDADES DO EXERCÍCIO DO DIREITO À EDUCAÇÃO NAS PRISÕES DO ESTADO DO RIO DE JANEIRO: UM ESTUDO DE CASO NO COLÉGIO ESTADUAL JOSÉ LEWGOY}

Prezada/Prezado,

O presente questionário é parte integrante da minha pesquisa de doutorado em andamento, intitulada "Limites e possibilidades do exercício do direito à educação nas prisões do Estado do Rio de Janeiro", desenvolvida junto ao Programa de Pós-graduação da Faculdade de Educação da Universidade de São Paulo (FEUSP). A pesquisa tem como objetivo investigar a efetiva aplicabilidade na proposta político-pedagógica de educação nas prisões do Estado do Rio de Janeiro, das Diretrizes Nacionais para a Oferta de Educação nos estabelecimentos penais, instituídas pela Resolução no 3/2009, do Conselho Nacional de Política Criminal e Penitenciária (CNPCP), cujo propósito é a institucionalização da educação em prisões como parte constituinte da política educacional brasileira.

Gostaria de convidá-lo(a) a contribuir, considerando sua atuação com a temática, seja de modo direto ou indireto.

A participação na pesquisa é voluntária, com finalidade exclusivamente acadêmica. Os resultados da pesquisa final serão compartilhados, em devolutiva direta, a SEAP e a SEEDUC. Em caso de aceite, agradeço, antecipadamente, as contribuições e coloco-me à disposição para eventuais dúvidas e esclarecimentos que se fizerem necessários, por meio dos contatos abaixo indicados. Por fim, incluo o Termo de Consentimento Livre e Esclarecido, para sua ciência.

Atenciosamente,

Taíza da Silva Gama

E-mail: taiza_gama@hotmail.com

Doutoranda em Educação - FEUSP

Orientador: Prof. Dr. Roberto da Silva 


\section{TERMO DE CONSENTIMENTO LIVRE E ESCLARECIDO}

Você está sendo convidada (o) como voluntária (o) a participar desta pesquisa. Todas as informações requisitadas serão utilizadas unicamente para fins de pesquisa, em nível de Doutorado. Ao participar deste estudo, estará permitindo a utilização dos dados fornecidos na presente pesquisa, que atesta pelo cumprimento dos preceitos éticos em pesquisas envolvendo seres humanos. Você tem liberdade de se recusar a participar e, ainda, de se recusar a continuar participando em qualquer fase da pesquisa.

1- Objetivo do estudo: investigar a efetiva aplicabilidade na proposta político-pedagógica de educação nas prisões do Estado do Rio de Janeiro, das Diretrizes Nacionais para a Oferta de Educação nos estabelecimentos penais, instituídas pela Resolução $n^{\circ}$ 3/2009, do Conselho Nacional de Política Criminal e Penitenciária (CNPCP), cujo propósito é a institucionalização da educação em prisões como parte constituinte da política educacional brasileira.

2- Procedimento: questionário de entrevista (impresso ou eletrônico)

3- Despesas e compensações financeiras: não existem

4- Riscos: nenhum

5- Benefícios: ao participar, você estará contribuindo para o mapeamento das ações relacionadas a educação nas prisões brasileiras. Este panorama será importante para a consecução dos objetivos do estudo, bem como para futuras propostas em relação ao tema.

6- Confidencialidade: os resultados deste estudo poderão ser publicados em periódicos ou apresentados em eventos acadêmicos e científicos. Se for de sua preferência, suas respostas serão tratadas confidencialmente, sem que a sua identidade seja revelada, ou seja, seus dados serão preservados de forma anônima. A opção de confidencialidade é a primeira questão deste questionário.

Ao inserir suas respostas no questionário, você declara que compreende como e sobre o que este estudo está sendo feito e que conhece seus direitos como sujeito da pesquisa. Declara ainda, que, voluntariamente, consente em participar deste estudo e em ceder seus dados para a pesquisa descrita acima.

Instruções: Escreva suas respostas em português. Sempre que possível, preencha os espaços fornecidos com informações adicionais. Caso a pergunta não se aplique ao seu caso, escreva "não se aplica".

Muito obrigada! 


\section{Professores/diretores}

\section{1- $\quad$ CONFIDENCIALIDADE}

Escolha abaixo a opção SIM caso queira que sua identidade seja preservada como anônima e suas respostas tratadas confidencialmente. Escolha a opção NÃO caso autorize a utilização dos dados e informações aqui fornecidos com a devida atribuição de créditos.

( ) SIM

2- $\quad$ Idade, sexo e cor

3- $\quad$ Formação acadêmica

4- $\quad$ Ano de ingresso como professorldiretor?

5- Qual matéria leciona na prisão?

6- Você recebeu alguma formação específica para trabalhar como professor no ambiente prisional?

7- $\quad$ Além de trabalhar no sistema prisional, você trabalha em alguma outra escola?

8- $\quad$ Qual é o papel da educação nas prisões para você?

9- $\quad$ Para você há diferença em lecionar dentro ou fora da prisão?

10- Você conhece as Diretrizes Nacionais para a Oferta da Educação em Estabelecimentos Penais?

11- Você tem conhecimento sobre o Plano Estadual de Educação em Prisões? E sobre o currículo do Estado para a educação em prisões? Participou das

12- Desde a aprovação das Diretrizes Nacionais em 2010, você percebeu alguma mudança na Educação em prisões no Rio de Janeiro?

13- Como você avalia as condições de oferta da Educação nas prisões do Rio de Janeiro?

14- Você acha que ter escolas próprias dentro da prisão e anexos destas escolas dentro da prisão é um bom modelo para professores e alunos exercerem o direito à Educação?

15- Você tem apoio de coordenação e de supervisão por parte da Secretaria da Educação?

16- Você tem apoio dos agentes penitenciários e dos diretores da unidade prisional para fazer o seu trabalho?

17- Você acha que o currículo e o material didático fornecido pela Secretaria de Educação é adequado para a Educação em Prisões?

18- Você tem algum tipo de apoio por parte das universidades para fazer o seu trabalho?

19- Como é tratado o professor da Educação em Prisões na estrutura da carreira do magistério no Estado do Rio de Janeiro? Qual é a sua opinião ou como acha que deveria ser?

20- Como você vê a possibilidade do Ensino a distância no sistema prisional?

21- Como você avalia a possibilidade de ter presos com formação pedagógica para auxiliar os professores dentro e fora da sala de aula?

22- Como você avalia a questão do acesso ao Ensino Superior por parte dos presos dos regimes semiaberto e fechado? 


\section{Alunos}

1- CONFIDENCIALIDADE

Escolha abaixo a opção SIM caso queira que sua identidade seja preservada como anônima e suas respostas tratadas confidencialmente. Escolha a opção NÃO caso autorize a utilização dos dados e informações aqui fornecidos com a devida atribuição de créditos.

( ) SIM

( ) NÃO

2- Quando entrou no sistema prisional pela primeira vez?

3- $\quad$ Unidade em que esteve preso pela última vez

4- Grau de escolaridade quando entrou no sistema pela primeira vez

5- Grau de escolaridade atual

6- $\quad$ Idade em que saiu da escola

7- Que ano ou série está estudando agora?

8- Por que decidiu voltar a estudar?

9- Como soube que é possível estudar na prisão?

10- Quais são os seus objetivos estudando?

11- Participa de atividades artísticas, esportivas, culturais, religiosas, além da escola?

12- Exerce algum trabalho na prisão?

13- Qual função exerce?

14- Qual é a sua preferência: trabalhar, estudar, ou fazer os dois?

15- A necessidade de trabalhar impede ou prejudica a dedicação aos estudos?

16- Você recebe dos agentes penitenciários algum incentivo ou apoio para estudar?

17- Com qual destes profissionais você se relaciona melhor na prisão: advogado, psicólogo, assistente social, médico, psiquiatra, padres e pastores ou professores. Por quê?

18- Como você avalia as condições de oferta da educação na prisão em termos de infraestrutura, sala de aula de aula, horários, material pedagógico e currículo?

19- Quando não está na sala de aula você estuda, discute as matérias ou dialoga sobre educação com alguém?

20- Fora da sala de aula você tem acesso a livros, cadernos e material de estudo? Pode usálos nas celas?

21- Para você, estudar na prisão, é um privilégio ou um direito?

22- Você tem conhecimento sobre o Plano Estadual de Educação em Prisões que a SEAP elaborou para o Estado do Rio de Janeiro?

23- Segue abaixo espaço destinado a eventuais comentários que deseje fazer 


\section{B. Negativa de acesso à informação - SEAP}

09:09/2019

SEI/ERJ - 1223493 - Despacho de Encaminh amento de Doctmento

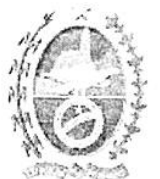

Governo do Estado do Rio de Janciro

Secretaria de Estado de Administração Pentenciaria

Subsecretaria Adjunta de Gestio Cperacional

Para: SEAP-CE

De: SEAP-OP

Cumprimentando-o, restitumos o presente indeferindo o pedido, com fulcro no art. 37 , s $3^{\circ}$, inciso II da CRFB/1998 e art. 23, inciso VIII da Lei 12.527/2011, ressaltando imprescindibilidade do sigilo à segurança da sociedade e do Estado, tendo em vista que os bancos de dados referentes aos apenados, servidores e demais profissionais que possuem relaçăo com a SEAP-R.I não se encontram abertos, devido à vulnerabilidade que traria a cstes cidadàos, um por se encontrar preso, outro por ser responsável por sua custódia no cumprimento da pena, ou por estarem prestando serviço à SEAP-RJ. É de conhecimento da Nação o Direito de Acesso à Informação, principalmente, no que se refere a prestação de serviços do Estado, entretanto, cumpre informar que, segundo o entendimento desta SEAP-OP, a demanda em exame, possui relação direta con a fragilização da Segurança e risco de exposição das atividades de inteligência, custódia. investigação, fiscalização e demais procedimentos que estejam em curso na forma da legislação supracitada.

Rio de Janciro. 09 de setembro de 2019

Documento assinado eletronicamente por Jurema Sodre da Silva, Assessora, em 09/09/2019, às 15:34, conforme horário oficial de Brasilia, com fundamento no art. 5, do $\$ 1 \%$, Decreto no 46.126 , de 20 de outubro de 2017.

at

$4 \%$ acao=documento conferir\&id_orgao acesso externo=6, informando o código verificador 1223493 e 回

Referência: Processo no SEi-21/033/001613/2019

SEI no 1223493

Edifício Dom Pedro II, Praça Cristiano Otoni, S/N - Bairro Centro, Rio de Janeiro/RJ, CEP 20221 -250

Telefone: $2334-5182$ 


\section{Autorização para realização da pesquisa}

Despacho 1498/2019
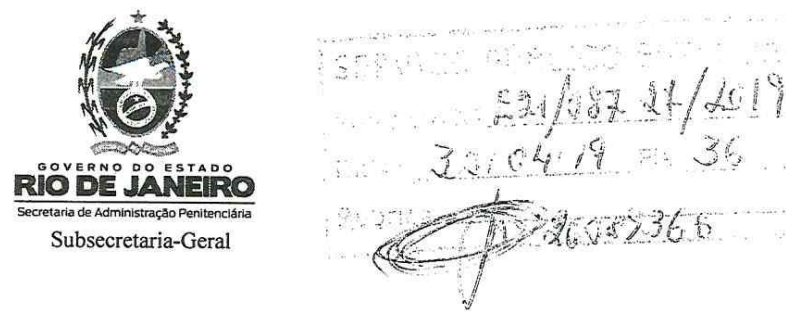

Subsecretaria-Geral

Ref.: $\mathbb{E}-21 / 087.27 / 2019$

\section{À SUBSECRETARIA ADJUNTA DE GESTÃO ESTRATÉGICA - SEAP/GE}

1- Considerando o nada a opor do Subsecretário da SEAP/OP;

2- $\mathbf{A U T O R I Z O}$ a realização da pesquisa acadêmica na SEAP/MS, devendo ser tomadas as medidas de segurança de praxe e as regras em vigor, para realização de pesquisa acadêmica nas Unidades Prisionais e Hospitalares da SEAP/RJ;

3- Encaminho para adoção das medidas decorrentes.

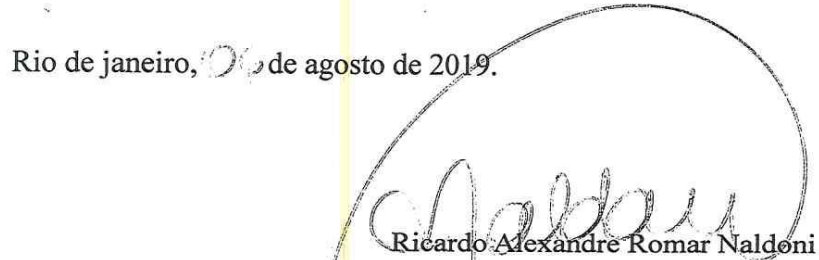

Subsecretário de Estado de Administração Penitenciária

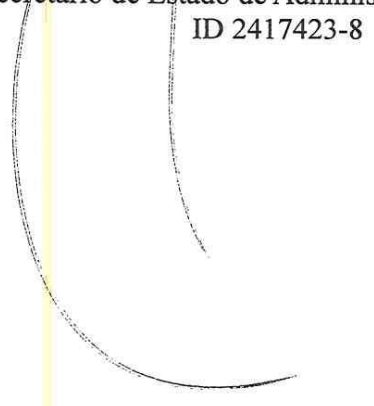

$\mathrm{ASB} / \mathrm{SG}$

Pça. Cristiano Ottoni, $s / \mathrm{n}^{\circ}$, Ed. D. Pedro II, $5^{\circ}$ andar, Sala 534 - Centro

Rio de Janeiro/RJ - CEP: 20221-250 -Tel. (021) 2334-6258 / 2334-6283

www.seap.rj.gov.br 


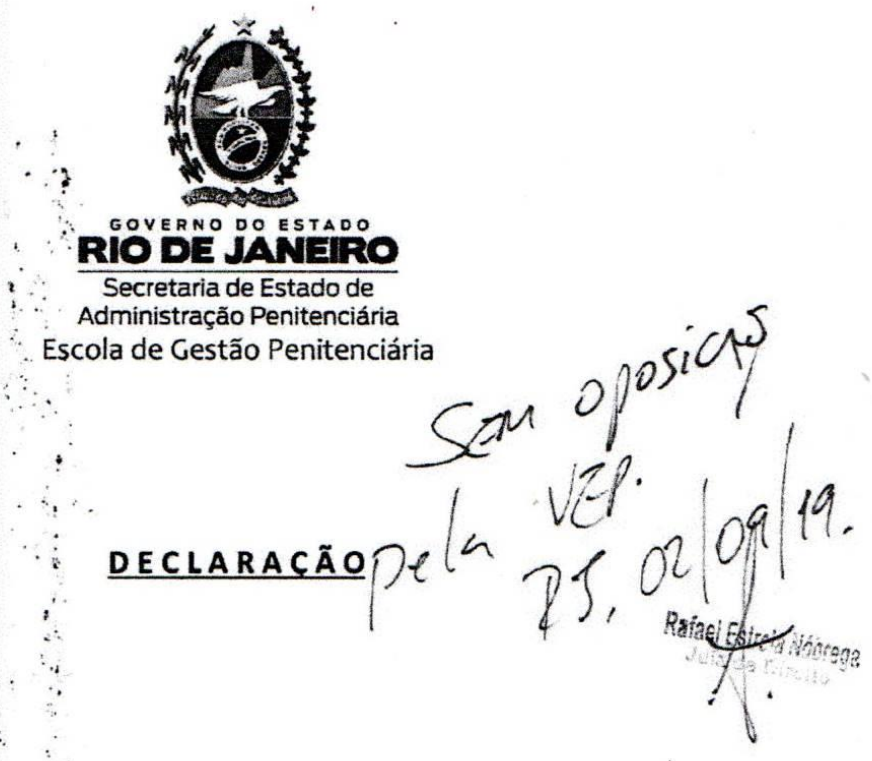

Declaramos para comprovação junto à Vara de Execuções Penais que a pesquisadora Taíza da Silva Gama, RG 20.214.325-1, solicitou autorização de pesquisa junto à Unidade: Penitenciária Móniz Sodré, SEAPMS, com o tema "Limites e Possibilidades do Exercício do Direito à Educaçắo nas Prisões do Estado do Rio de Janeiro" e que para tal se faz necessária paralela:autorização do Juiz da VEP.

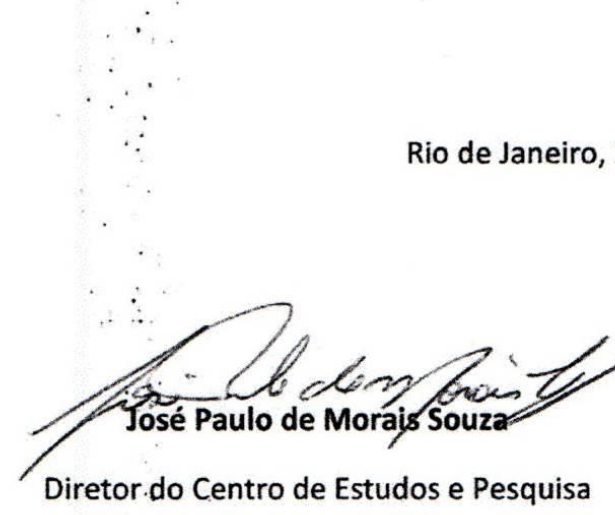

Id. Func. 19984529 
D. Projeto político pedagógico do Colégio Estadual José Lewgoy

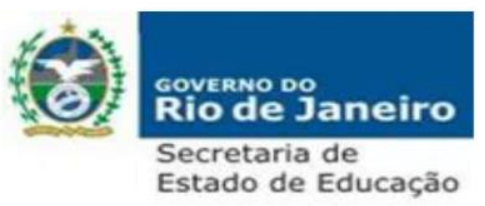

SECRETARIA DE ESTADO DE EDUCAÇÃO

SUBSECRETARIA DE GESTÃO DA REDE E ENSINO

DIRETORIA ESPECIAL DE UNIDADES PRISIONAIS E SOCIOEDUCATIVAS

CE JOSÉ LEWGOY - UA 186983

PROJETO POLÍTICO PEDAGÓGICO

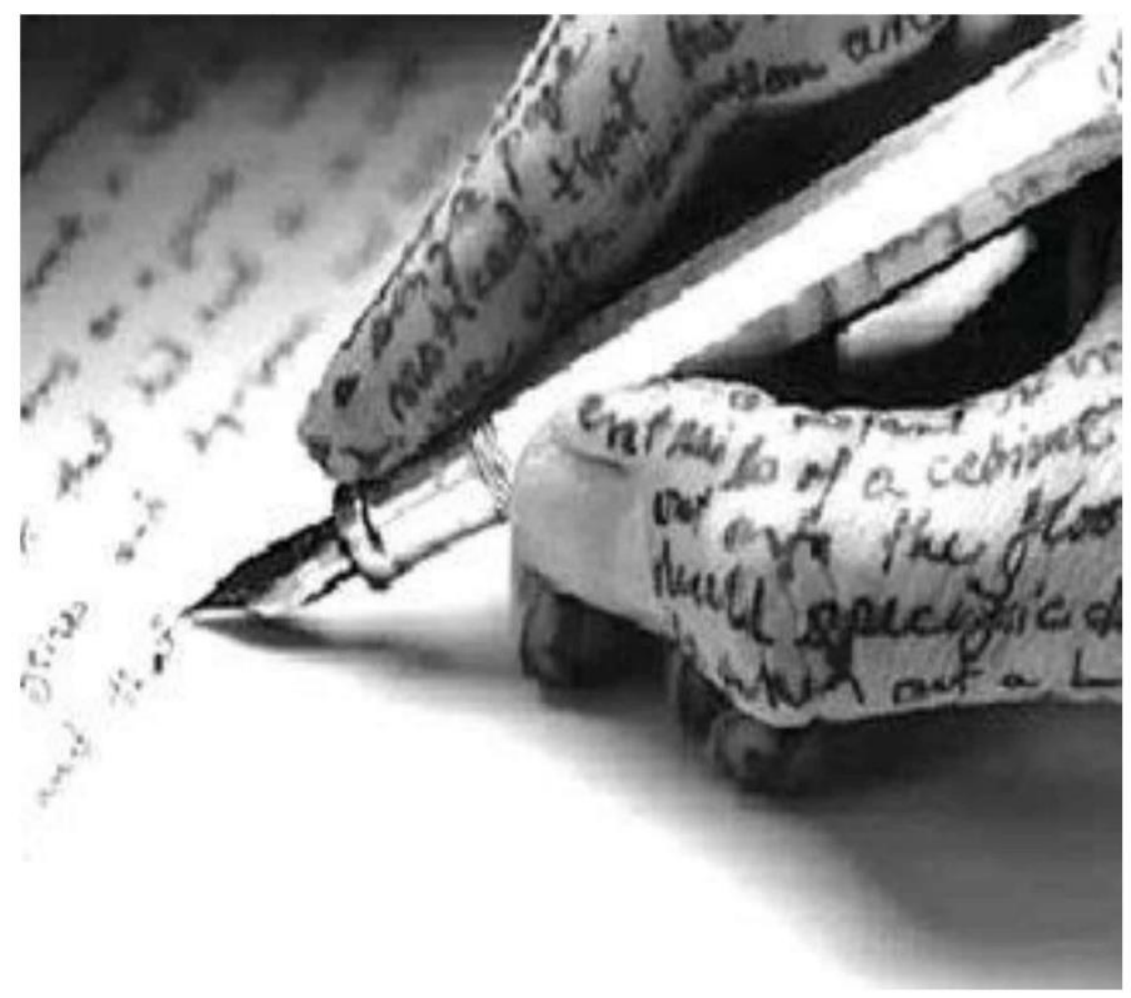

MEMÓRIA E LETRAMENTO: CONSTRUÇÃO DA AUTORIA

Triênio

$2017-2019$ 
Ouvi, esqueci. Vi, me lembrei. Fiz, aprendi. Confúcio 


\section{SUMÁRIO}

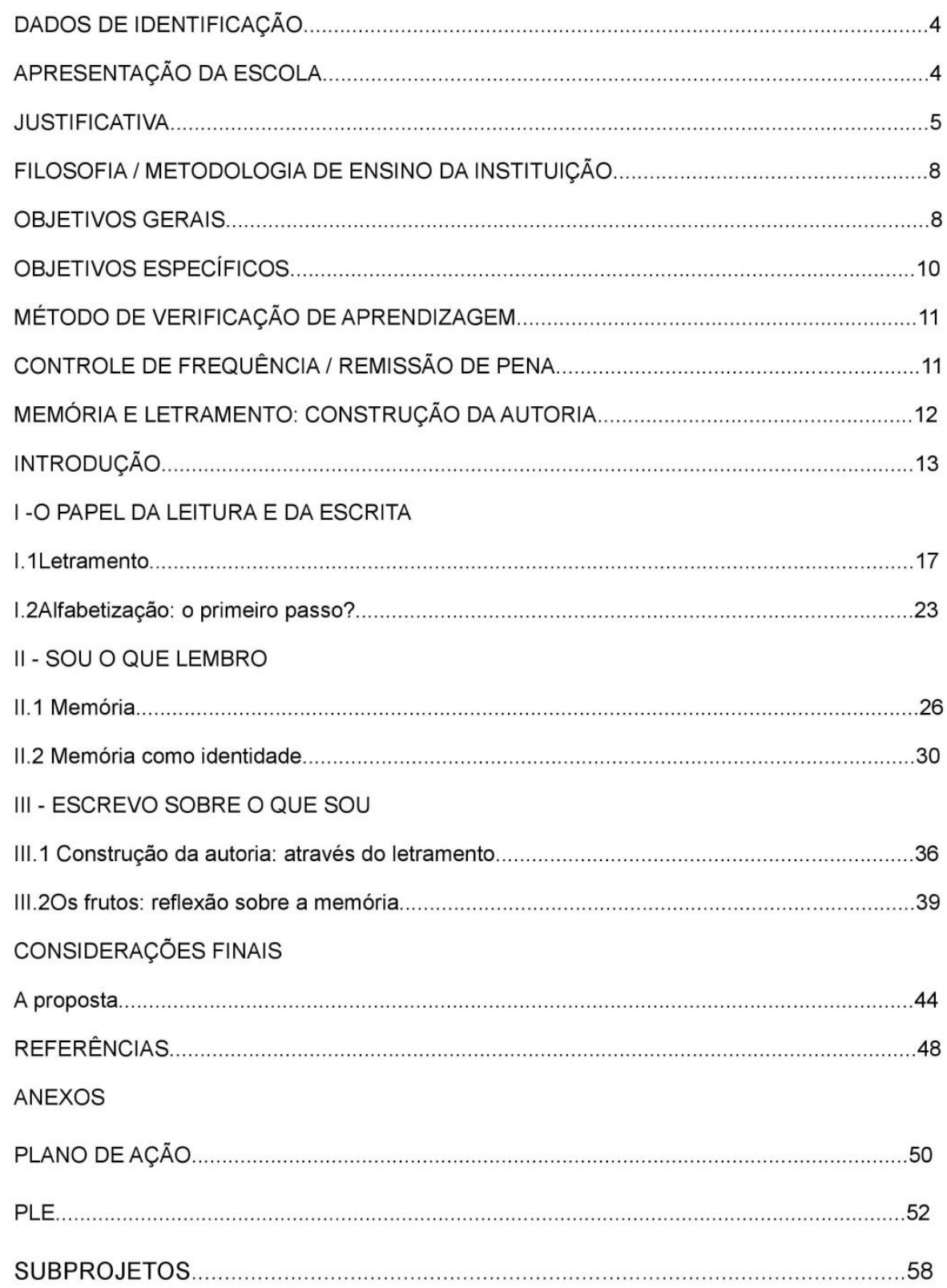




\section{DADOS DE IDENTIFICAÇÃO}

Escola: Colégio Estadual José Lewgoy

Entidade Mantenedora: Secretaria Estadual de Educação

Ato de Criação: Decreto $n^{\circ} 38.997$ de 15/03/2006

Censo: 33146160

Grau de Ensino: Ensino Fundamental e Ensino Médio - Modular Semestral

Direção Geral: Lania Régia Alves

Direção adjunta:

Localização: Complexo do Gericinó - Penitenciária Moniz Sodré e Penitenciária Joaquim Ferreira de Souza

Estrada General Emílio Maurel Filho, 300.

Gericinó - Rio de Janeiro - RJ

Tel.: (21) 2333-4981

\section{APRESENTAÇÃO DA ESCOLA}

"Precisamos contribuir para a escola que é aventura, que marcha, que não tem medo de risco, por isso que recusa o imobilismo. A escola em que se pensa, em que atua, em que se cria, em que se fala, em que se ama, se adivinha, a escola em que aproximadamente diz sim à vida." (Paulo Freire)

O Colégio Estadual José Lewgoy está localizado no Complexo Penitenciário de Gericinó no bairro Bangu, no município do Rio de Janeiro. A escola atende a indivíduos que se encontram em privação de liberdade na Penitenciária Moniz Sodré (público masculino). Com suas dependências construídas numa estrutura que era uma galeria, onde foram criadas 6 salas, atende às necessidades educativas dos internos há 8 anos.

A escola possui atualmente, o total de 153 alunos matriculados com idade acima de 18 anos. No presídio masculino, atualmente, os internos cumprem pena judicial em regime semiaberto e na sua maioria são jovens entre 18 e 25 anos. 
Atualmente, a população carcerária desta Unidade Prisional é de cerca de 2800 internos. Devido ao espaço físico inadequado ocupado pela escola, fica inviável atender a demanda de internos que têm o desejo de estudar, por isso o número muito reduzido em relação ao número de internos.

A escola atende em dois turnos: manhã (9:00h às 12:00h) e tarde (13:00h às 16:00h). A direção, parte administrativa e pedagógica, fica juntamente com outros setores administrativos da Unidade Prisional e possui 01 (uma) sala reservada para a direção e direção adjunta com 2 (duas) mesas com computadores, aparelho de telefone, 01 (um) armário que guarda materiais escolares e 01 (um) freezer que guarda as merendas perecíveis em uma pequena dispensa. $\mathrm{O}$ espaço conta também com 02 (dois) arquivos com as fichas dos alunos inativos e 04 (quatro) armários com para armazenar merenda e guardar documentos da unidade escolar. A escola foi adaptada em 06 (seis) salas de aulas, onde são guardados materiais didáticos, 01 (um) espaço administrativo-pedagógico e 02 (dois) banheiros. Em cada sala de aula há 01 (um) quadro branco para caneta, 01 (um) armário, 01 ar condicionado, ventiladores, carteiras, mesa para o professor e iluminação. Mas, as salas não são muito ventiladas pois não há janelas e os ares-condicionados funcionam deficientemente por conta da parte elétrica da Unidade Prisional não estar adequada para os aparelhos.

O corpo técnico-administrativo e pedagógico da escola constitui-se de 01 (uma) diretora geral. O corpo docente é composto de 18 (dezoito) professores, sendo estes concursados pela Secretaria de Estado de Educação ou especificamente para a Diesp.

Dentro do espaço escolar atuam monitores, que são apenados que auxiliam o trabalho dos professores e do pessoal de apoio.

Os professores e demais funcionários realizam um trabalho interativo dentro da escola. Em nossa proposta sintetizamos que não é a aprendizagem que deve se ajustar ao ensino, mas, sim, o ensino que deve potencializar a aprendizagem. Logo, acreditamos que cabe a escola orientar a formação integral do indivíduo, garantindo Ihe a aprendizagem com a apropriação de saberes significativos, tornando - o capaz de interferir com competência e criticidade na sua própria realidade social. 


\title{
JUSTIFICATIVA
}

A Constituição Brasileira de 1988 preserva o princípio das Declarações dos Direitos do Homem e estabelece, no Capítulo II, os "Direitos Sociais à educação" como sendo um deles, além de garantir no art. 205 que:

\begin{abstract}
A educação, direito de todos e dever do Estado e da família, será promovida e incentivada com a colaboração da sociedade, visando ao pleno desenvolvimento da pessoa, seu preparo para o exercício da cidadania e sua qualificação para o trabalho.
\end{abstract}

Já o art. 208 define de que forma a educação deve ser efetivada e garante que o Ensino Fundamental é obrigatório e gratuito para todos, inclusive para "todos os que a ele não tiveram acesso na idade própria".

Seguindo este mesmo princípio, a Lei de Diretrizes e Bases da Educação Nacional - LDB ratifica este direito e considera que o acesso ao Ensino Fundamental "é direito público subjetivo". Isto significa dizer que o Poder Público pode ser acionado juridicamente para que as pessoas tenham este direito garantido

Então, o princípio fundamental que deve ser preservado e enfatizado é que a educação no sistema penitenciário não pode ser entendida como privilégio, benefício ou, muito menos, recompensa oferecida em troca de um bom comportamento. Educação é direito previsto na legislação brasileira. A pena de prisão é definida como sendo um recolhimento temporário suficiente ao preparo do indivíduo ao convívio social e não implica a perda de todos os direitos

O Artigo 12 da Lei 9394/96 define a incumbência dos estabelecimentos de ensino, dentre elas, elaborar e executar sua proposta pedagógica. $\mathrm{O}$ artigo 14 trata da gestão democrática do ensino público na educação básica, incluindo a participação de profissionais da educação na elaboração do projeto pedagógico da escola e das comunidades, escolar e local, em conselhos escolares ou equivalentes. Seguindo essas orientações, apresentamos neste documento a proposta pedagógica da instituição prisional José Lewgoy, que baseia seus compromissos de ensino na busca de um aprendizado voltado para a prática e o auto-conhecimento, incluindo o desenvolvimento social e emocional dos envolvidos no processo de ensino aprendizagem. 
A atual LDB não contempla dispositivos específicos sobre a educação no sistema penitenciário nacional. Que embora relativamente antiga no Brasil, sendo objeto de determinação legal ainda nos primórdios da república, a educação prisional tem sido, recentemente, objeto de maior atenção governamental. Iniciativas de organismos federais brasileiros, notadamente das áreas da justiça e da educação, têm ressaltado a importância estratégica do trabalho pedagógico, desde que criativo e de qualidade, além de adequado ao universo do sistema penitenciário.

Ao contrário de simplesmente impedi-los da livre convivência social, se faz necessário que no curso de sua permanência em uma instituição prisional, os presos, especialmente os considerados de baixa periculosidade, participem de programas destinados a impedir sua futura reincidência no crime. Esta, além de perpetuar a condenação de indivíduos a condições existenciais degradantes, reafirmando perversamente os efeitos decorrentes das desigualdades sociais que caracterizam a história de vida de quase toda população carcerária do país, implica na alocação de maiores recursos públicos para a manutenção (e ampliação) dos serviços de segurança e dos complexos presidiários, recursos que poderiam ser mais bem empregados no atendimento de outras demandas da sociedade, como saúde, educação, geração de emprego, etc.

Entre as iniciativas governamentais existentes, desta - se: o Programa Nacional de Seguridade Pública com Cidadania (PRONASCI), o II Seminário Nacional de Consolidação das Diretrizes para a Educação no Sistema Penitenciário (realizado em Brasília, em outubro de 2007) e o Projeto Educando para a Liberdade. Todas elas situam como um de seus principais objetivos a ampliação da escolaridade da população carcerária, que em sua maior parte, ou não teve maiores oportunidades de escolarização ou apresenta trajetórias de experiências escolares mal sucedidas. No conjunto, essas iniciativas têm ressaltado a importância de se entender a educação prisional como temática pertinente à educação de adultos e procuram concretizar o disposto em documentos como a Declaração Universal dos Direitos Humanos, a Constituição Federal brasileira, a atual Lei de Diretrizes e Bases da Educação e a Lei de Execução Penal de 1984.

O Plano Nacional de Educação (PNE), votado no Congresso em 2001, no capítulo III referente à Modalidade de Ensino - Educação de Jovens e Adultos, estabelece a necessidade de: 
"implantar, em todas as unidades prisionais e nos estabelecimentos que atendem adolescentes e jovens infratores, programas de educação de jovens e adultos de nível fundamental e médio, assim como de formação profissional".

Contemplando para a população carcerária, as metas relativas ao fornecimento de materiais didático - pedagógicos pelo Ministério da Educação (MEC) e à oferta de programas de educação à distância. A Constituição Brasileira, a Declaração Universal dos Direitos Humanos, o disposto nos Parâmetros Curriculares Nacionais - PCN, a deliberação de Diretrizes e Bases da Educação nas prisões e a LEP (Lei de Execuções Penais) tem sido os norteadores de nossa proposta.

\section{FILOSOFIA/METODOLOGIA DE ENSINO DA INSTITUIÇÃO}

A metodologia de ensino do COLÉGIO ESTADUAL JOSÉ LEWGOY está baseada na proposta humanista, ou seja, o grande projeto da vida é os seres humanos se construírem como cidadãos. Pessoas realizadas, produtivas e afetivas. Uma construção contínua, com contradições, mas constante nesse objetivo maior que é humanizar. Alimentando as esperanças e aproveitando a religiosidade do alunado para fazê - los evoluir sempre mais. Encorajando - os a fazer melhores escolhas para que no futuro possam ter uma vida mais livre e realizadora. Um dos objetivos da nossa proposta é garantir aos nossos educandos o acesso a educação de qualidade, com a perspectiva de reintegrá - los à sociedade, trabalhando o educando na sua totalidade, num compromisso concreto com a construção de um saber que permita ao educando desenvolver suas potencialidades, favorecendo a vivência da solidariedade, da justiça, do amor, do diálogo, do respeito ao próximo e do exercício da cidadania, em vista de novas oportunidades ao seu retorno à sociedade.

Nossa proposta pedagógica privilegia o ensino enquanto construção do conhecimento, o desenvolvimento pleno das potencialidades do aluno e sua reinserção no ambiente social. Utilizando, para isso, os conteúdos curriculares da base nacional comum e os temas transversais, trabalhados em sua contextualização.

\section{OBJETIVOS GERAIS}

Temos uma proposta educacional comprometida com a democracia e a cidadania. 
Nesse sentido, baseados no texto da Constituição, nos direitos humanos, na Lei de Execuções Penais e nos Parâmetros Curriculares Nacionais - PCNs - que nos orientam quantos aos princípios gerais da educação e que visam à consecução das seguintes metas:

- Garantir educação humanizadora, elevando assim, a autoestima dos nossos alunos;

- Valorizar o respeito aos direitos humanos e incentivar a exclusão de qualquer tipo de discriminação nas relações interpessoais, públicas e privadas;

- Realizar parcerias para viabilizar o acesso a cursos de profissionalização ao nosso educando, oferecendo meios para que o mesmo, adquira melhores condições de inserir - se no mercado de trabalho.

A LDB, mesmo não contemplando especificidades em educação prisional tem na cidadania seu eixo orientador e se compromete com valores e conhecimentos que viabilizam a participação efetiva do aluno na vida social; em função disso, são três as nossas diretrizes de ensino:

- Posicionamento em relação às questões sociais e visão da tarefa educativa como intervenção intencional no presente;

- Tratamento de valores como conceitos reais, inseridos no contexto do cotidiano;

- Inclusão dessas perspectivas no ensino dos diversos conteúdos escolares.

A inclusão de temas sócio - culturais no currículo transcende o âmbito das diversas disciplinas e corresponde aos Temas Transversais, preconizados pelos PCNs, caracterizando - se por:

- Urgência social;

- Abrangência nacional;

- Possibilidade de ensino e aprendizagem aqui aplicados na educação de jovens e adultos em privação de liberdade. 
Na forma de:

- Ética;

- Diversidade cultural;

- Meio - ambiente;

- Saúde;

- Orientação sexual;

- Trabalho e consumo;

- Temais locais.

Ser espaço físico, pedagógico, político e cultural de formação de sujeitos, conhecedores e praticantes de plena cidadania e de consciência crítica, capazes de produzir e compartilhar os conhecimentos, transformando-os em aprendizagem concreta e viabilizadora que venha a favorecer o crescimento social dos discentes.

\section{OBJETIVOS ESPECÍFICOS}

- Reconhecer a educação oferecida como um direito instituído por lei;

- Utilizar as dependências da escola de maneira reflexiva;

- Perceber - se integrante, dependente e agente transformador do meio ambiente, contribuindo para a melhoria do mesmo;

- Adquirir habilidades para a vida profissional pós - cárcere;

- Empregar as variadas formas literárias;

- Posicionar - se crítica, responsável e construtivamente nas diversidades, utilizando o diálogo na mediação de conflitos e nas decisões coletivas;

- Adquirir de habilidades de síntese, argumentação e aplicação de conhecimentos;

- Perceber - se parte integrante do meio ambiente e reconhecer a importância da conservação e sustentabilidade do mesmo;

- Resgatar a importância da família, destacando - a como primeira instituição na qual fazemos parte e a suma relevância em nos conduzir a uma vida em fraternidade, dotando - nos de razão e consciência para agirmos com as outras pessoas com espírito da fraternidade; 
- Ressaltar a importância da família, fazendo com que os alunos compreendam que uma família pode nascer a partir de um indivíduo, ainda que o mesmo não tenha participado de uma estrutura familiar;

- Despertar para uma nova consciência, onde cada um é responsável por um futuro melhor, iniciado no presente a medida que perdoam o passado;

- Reformular juízos de valores a partir da vivência no ambiente social;

- Fazer uso de diferentes linguagens para produzir, expressar e transmitir suas idéias;

- Utilizar diferentes fontes de informações para adquirir e construir conhecimentos;

- Compreender direitos e deveres de cidadania;

- Exercer o direito de participar da vida cultural, através de eventos em nossa Unidade Escolar. Com isso promovendo subsídios para a reinserção social.

- Sonhar, partilhando o sonho e as ações para realizá-los;

- Demonstrar atitude de humildade, mas também de autoconfiança;

- Respeitar o meio ambiente, reconhecendo a responsabilidade de deixar recursos naturais necessários para a sobrevivência das gerações futuras.

- Ser autor do seu conhecimento.

\section{MÉTODO DE VERIFICAÇÃO DA APRENDIZAGEM}

De acordo com o que foi decidido pela equipe pedagógica na reunião de planejamento estratégico, que aconteceu no primeiro bimestre do ano letivo em vigor, serão trabalhados conteúdos em todas as turmas com o objetivo de promover a melhoria do nível de aprendizagem dos alunos.

A avaliação do processo ensino-aprendizagem será feita de três formas:

I - Prova objetiva e/ou operatória valendo aproveitamento de zero a cinco pontos:

II - Avaliação formativa, englobando participação e interesse nos encontros, valendo aproveitamento de zero a dois pontos;

III - Avaliação através da participação das oficinas e projetos da unidade escolar, valendo aproveitamento de zero a três pontos. 
Ao detectar dificuldades de aquisição dos conteúdos curriculares por parte dos alunos, ou um resultado inferior a $50 \%$ (sessenta por cento) nas avaliações, o professor deverá organizar um plano de estudos ou atividades diversificadas para serem realizadas pelo discente. O objetivo é implementar estratégias alternativas capazes de dinamizar novas oportunidades de aprendizagem para o educando, aplicando ao mesmo todos os recursos necessários, que venham contribuir para seu melhor desempenho.

No caso dos alunos das turmas do $1^{\circ}$ segmento do Ensino Fundamental, seguindo orientações da resolução $n^{\circ} 2336 / 2004$, serão preenchidos relatórios individuais a cada bimestre - de habilidades e competências - , e ao final do ano letivo um relatório final descritivo, contendo todas as informações do processo ensinoaprendizagem de cada aluno.

\section{CONTROLE DE FREQUÊNCIA/REMIÇÃO DE PENA/REMIÇAO POR LEITURA}

Segundo o Plano Estadual de Educação do Estado do Rio de Janeiro, “...Em 2000, o convênio foi renovado e algumas escolas do sistema penitenciário passaram também a oferecer o Ensino Médio. Vale destacar também que, ainda em 2000, a remição de pena pelo estudo foi concedida pela Vara de Execuções Penais, pelo Ministério Público e pelo Conselho Penitenciário do Estado do Rio de Janeiro. A cada 18 horas de estudo, reduz-se um dia de pena, enquanto a remição por trabalho, prevista no art. 126 da Lei de Execução Penal, equivale à redução de três dias de trabalho por um dia de pena. Vale ressaltar que a carga horária de trabalho dos internos é de, no mínimo, 6 horas e, no máximo, oito horas, enquanto que, na escola, permanecem por três horas diárias. Como na escola a carga horária é inferior a do trabalho, os internos que optam pelo estudo levam quatro dias para remir um, o que acaba os desmotivando e, consequentemente, afastando os apenados do espaço escolar, uma vez que a remição assume grande importância na vida desses sujeitos, já que é uma forma de alcançar a liberdade o mais breve possível."

Baseado neste documento, todos os internos devidamente matriculados no COLÉGIO ESTADUAL JOSÉ LEWGOY, recebem uma planilha nominal, que é assinada ao término de cada aula que compareceram e participaram como forma de controle e comprovação de frequência, afim de computar horas para remir suas penas.

Desde o ano de 2017, a escola vem participando, como colaboradora, junto a SEAP, no processo de remição por leitura, atendendo aos alunos da escola podendo 
ser estendido aos internos que não são matriculados

A escola se incumbe de emprestar livros, fazer as avaliações, de acordo com a lei vigente sobre remição por leitura. Os professores fazem a avalição e aqueles que obtém resultados igual ou superior a 6,0 tem sua avalição enviada ao setor de classificação, que envia para a Vara de Execuções Penais. 


\section{MEMÓRIA E LETRAMENTO: CONSTRUÇÃO DA AUTORIA}

Este projeto propõe a apresentação da importância do letramento na formação dos alunos de uma escola do sistema prisional do Rio de Janeiro no Colégio José Lewgoy. Os modos de constituição das memórias de alguns desses sujeitos foram observados e analisados ao mesmo tempo em que se acompanhava o processo de construção de autoria. Desenvolvendo relatos através de temas que se propunham estimular a escrita das próprias vivências desse grupo de alunos, no momento encarcerados, tem como objetivo principal destacar a figura do autor e como se representa a identidade de quem escreve o relato de suas memórias. Permeia todo o trabalho a importância do letramento em todas as etapas de aquisição de conhecimento, em todos as agências sociais, em todas as áreas do conhecimento, particularmente na sua agência mais significativa sob a vista do ensino formal, que é a escola, espaço de aquisição da leitura e da escrita.

Palavras-chave: Escola, Alfabetização, Letramento, Memória, Autoria.

\section{INTRODUÇÃO}

Se faz necessário aos professores que lecionam no sistema prisional fazer uma série de observações diferenciadas, se compararmos com os alunos do ensino regular. A perda da liberdade incide, obviamente, em diversas mudanças de comportamento, e também e na adoção de um comportamento típico de quem pertence a esse grupo de apenados desprovidos da liberdade social. Uma das adaptações mais imediatas a ser feita pelo professor diz respeito ao uso de um vocabulário mais adequado ao perfil dos alunos das escolas prisionais. Não é nada, em princípio, de complexidade extrema, somente uma observação (feita com cautela) de termos que podem não ser bem interpretados por possuírem, dentro do universo carcerário, outra conotação. Há uma fala nativa construída dentro das penitenciárias do nosso país que apresenta apenas variações regionais, como pude observar ouvindo as conversas entre os alunos apenados oriundos de diversas regiões. Há diferença de fala dependendo da origem, seja de cidades ou de estados. Observei que termos gerais eram comuns ao grupo, como também é notório que esses termos comuns passam a ter significado distinto e específico, diferente dos que representam no mundo além grades e muros da prisão, confrontamo-nos com uma variante da língua portuguesa restrita ao universo prisional. Como observa Fiorin (2002) sobre comunidade de fala e suas variantes: 


\begin{abstract}
"Embora o indivíduo possa utilizar variantes, é no contato linguístico com outros falantes de sua comunidade que ele vai encontrar os limites para sua variação individual. Como o indivíduo vive inserido numa comunidade, deverá haver semelhanças entre a língua que ele fala e a que outros membros da comunidade falam." (FIORIN, 2002, p.128)
\end{abstract}

A observação dessas variantes e a necessidade de adequação a um padrão tacitamente estabelecido deu corpo ao interesse em observar as pontes que eram feitas entre a língua comum a todos e o emprego específico; porque como qualquer grupo que busca uma identificação entre seus pares, os apenados também estabelecem, entre outras marcas, o uso de um vocabulário específico para estabelecer comunicação entre eles, cujo conteúdo é bastante interessante e curioso. Inicialmente, entender o quê e o porquê de determinadas escolhas exige atenção por parte do ouvinte. No decorrer do trabalho de observação feito, a identificação dos termos utilizados foi ficando mais fácil - pode-se contar com a ajuda dos detentos, que foram os tradutores. Mas o porquê das escolhas dos significados permanece como um fenômeno de criação coletiva, anônimo.

Para facilitar o relacionamento com os alunos da realidade prisional, é preciso respeitar, entre outras coisas, na fala que adotam, a adaptação que fazem dos termos de uso comum para um uso específico na rotina prisional. Como é uma adaptação muito peculiar, interessou-me saber mais dessa realidade e entender a motivação de algumas escolhas, dentro desse fenômeno linguístico de intensa polissemia.

$\mathrm{Na}$ medida em que fui me familiarizando com os termos nativos e aprendendo a usá-los como o prescrito pelo grupo, respeitando seus significados e assim evitando alguns e novamente significando outros, cresceu concomitantemente o desejo de estimular a produção textual de maneira que eles adquirissem a autossuficiência, confiança e segurança para escrever sobre suas vivências, construindo, a partir das próprias memórias, seu processo de letramento que levasse ao que Rojo (2009) diz ser a abordagem que trata das competências atribuídas à leitura, do que um leitor deve "constituir-se", como: dominar linguagem, compreender fenômenos, enfrentar situações-problema, construir argumentação, elaborar proposta, entre outras competências e habilidades. No processo dessa escrita autográfica, o aluno foi-se percebendo de posse dessas "ferramentas constituídas" para trabalhar sua memória e construir sua autoria. 
Dada a necessidade humana de narrar, de expor por escrito ou oralmente suas angústias e anseios, consideramos ainda maior essa necessidade de compor narrativas dentro da realidade vivida em um ambiente prisional, o que nos levou a conduzir, canalizar, essa necessidade para a prática da escrita memorialística.

A partir da compreensão da dimensão plural do(s) letramento(s) e observando a leitura e a escrita como prática social, via de acesso à capacidade de ser crítico (Freire, 1987), estimulou-se o uso dessas práticas como propulsoras do senso de coletivo, do espírito de cidadania e da capacidade de interceder enquanto sujeito social. Apoiamonos, portanto, em Soares (2000), quando afirma que o conceito de letramento é resultado da ação de ensinar e aprender práticas sociais de leitura e escrita, ou seja, o estado ou condição que um grupo ou indivíduo adquire quando se apropria da escrita e, por consequência, das práticas sociais que a mesma favorece.

Kleiman (1985), ao afirmar que existem agências de letramento além da escola como a igreja, a família, a rua, o lugar de trabalho, e que o letramento pode ser autônomo ou ideológico, favorece conceitualmente o desenvolvimento deste trabalho. O espaço escolar propicia ainda as condições para as construções de memória dos alunos e, por conseguinte, permite que eles se tornem autores plenos de seus registros. Isso também propicia que eles desenvolvam o letramento ideológico, cujas definições apontam para que as práticas de letramentos, no plural, sejam social e culturalmente determinadas quando associadas ao contexto.

Quanto maior o contato com ambientes e situações que favoreçam a proximidade com a leitura, maiores as chances de haver um processo de aquisição dos códigos mais eficiente - que é o passo inicial que precede os processos de letramento propriamente ditos e favorece a possibilidade de construção de um processo de autoria, constituindo-se assim o ambiente leitor formador da criança, segundo Terzi (2001). É, na verdade, a consolidação da apreensão do código a prática necessária para que aconteça, de fato, o letramento. Levando essa prática para o universo desses alunos que são detentos, uma rotina, uma familiaridade com a leitura se torna necessária para que isso se incorpore ao cotidiano deste aluno como um hábito, uma rotina capaz de tornar-se alvo de seu interesse. 
Ultrapassando a precariedade de bibliotecas disponíveis no ambiente prisional, textos avulsos e trechos de livros lidos para o grupo foram ferramentas úteis utilizadas, nesta pesquisa, para desencadear um processo de apreensão dos gêneros e estilos sobre determinado tema e favorecer a própria escrita enquanto autoria.

Isso pode ser visto na espontaneidade e simplicidade como descreveram episódios infantis, como é o caso do aluno Cosme André que narra em um texto especialmente divertido as farras de infância, recheado de lembranças típicas de criança. Ele nos conta passagens que denotam como ele via o efeito de suas travessuras. Nessa linha de reflexão do desenvolvimento de letramento ideológico, do qual fala Kleiman (1995), os significados específicos da escrita estão contextualizados e instituídos. Não há uma relação causal entre letramento e progresso, civilização ou modernidade. Os alunos, ao falarem de suas vivências, as associam à sua condição atual de apenados e constroem uma memória reflexiva, como autores que releem sua própria história de vida. Eles fizeram isso sem dar um tom dramático aos seus depoimentos, foram histórias e, como a maioria, ora com fatos felizes, ora nem tanto.

Dado que a revelação e construção de memória é um processo que requer antes um percurso de aceitação da própria história - nem sempre bem sucedido -, esse caminho de aceitação não obriga a reescrever um passado com photoshop, ou seja, retocando para parecer melhor ou mais interessante, ainda que alguns lancem mão desse recurso. De acordo com Brait (1997) é preciso, lançando mão da Filosofia, usar a consciência para se (re)conhecer dentro do advento da subjetividade do ser para a consciência, que:

\footnotetext{
"É uma capacidade, ou melhor, um poder de síntese, uma atividade que reconhece ou que produz, a partir de si mesma o sentido do real, pela produção de ideias ou conceitos dos objetos e dos estados anteriores; estas atividades epistemológicas e esse poder definem aquilo que a Filosofia denomina o sujeito." (BRAIT,1997, p.282)
}

$\mathrm{Na}$ escrita desses homens - hoje privados da liberdade social, e antes muitas vezes privados de direitos fundamentais de qualquer ser humano -, não se enxerga um lirismo estético, uma beleza plástica, mas ainda assim o texto enxuto, seco e sem formosura retém o interesse por ser verídico, espontâneo e genuinamente autoral. Ainda segundo Brait, a questão é que a verdade não é simplesmente reconhecida, mas produzida pelo homem nesse processo de percepção de si próprio. O "eu penso" é a primeira verdade, a de acesso mais imediato e o ponto de partida de todas as outras evidências que serão produzidas por esse mesmo "eu penso". 
A fala e escrita inserem-se, enquanto práticas efetivas, num quadro comunicacional que privilegia a multiplicidade, a diversidade, a diferença, a alteridade ou, para usar os termos de Bakhtin (2000), a polifonia, o dialogismo, a heteroglossia, Nesse quadro, instauram-se relações intersubjetivas em que o um e o outro, isto é, falante/ouvinte, escritor/leitor se constituem enquanto sujeitos do discurso.

Não é a superação ou recriação de um gênero literário que se buscou com este trabalho proposto aos participantes desta pesquisa, mas sim o valor da construção criativa da memória como ferramenta para a formação pessoal de sua própria história, que pode e merece ser narrada. Não houve, em momento algum, a preocupação com a plástica, a boa apresentação gramatical ou sintática do que estava sendo escrito, e ainda assim, dentro da constante simplicidade com que as memórias foram surgindo, pôde se apreender toda emoção e consequente beleza que é um ser humano contando o que o construiu, o que ele viveu e sentiu. Mais do que depoimentos, foram valorizadas as histórias e a capacidade de expressão dos sujeitos, alternando, entre as lembranças jocosas, evidências de desigualdade social e sua pungente injustiça, como também alegria e saudade. Sobre isso, fazemos destaque a fala de Biar:

\begin{abstract}
"Uma das principais consequências teóricas de se entendera narrativa como uma prática cultural, é que esta fica naturalmente destituída de uma função fundamentalmente informacional. Seu efeito pragmático, ou efeito de uso, é muito afetivo, relativo ao conhecimento enquanto membro de uma cultura, de uma comunidade de prática, de uma família. ( BIAR, 2011 p.10)
\end{abstract}

Destituir a narrativa de uma função meramente informacional exige ressignificar afetivamente os elementos dessa narrativa, para que a construção seja verdadeiramente um processo de aquisição concreto, baseado nas vivências, destacando os sentimentos e seus desdobramentos. A proposta de rever o passado instaurou a intenção de que os alunos pudessem reler seu presente, como um agente ativo que pode atuar sobre suas escolhas. O que pode fundamentar essa construção é o prazer da leitura e da escrita, mas da leitura e da escrita descobertas como ferramentas. Como define Yunes (1996, p. 48), "ler para viver. Ler a vida. Ler para ampliar as perspectivas, para associar ideias, para reinventar o mundo, a partir da condição pessoal."

Assim sendo, este trabalho pretende partilhar a experiência da descoberta da escrita pela própria escrita, numa leitura pessoal de letramento através da memória pessoal desses alunos. 


\section{I -O PAPEL DA LEITURA E DA ESCRITA}

\section{I.1Letramento}

Letramento é, como já foi anteriormente apresentado, a prática social da leitura e da escrita. Segundo Kleiman (1995), algum processo de letramento se estabelece, quando há uma coexistência de posturas de aplicação social em qualquer contexto que envolva a leitura e/ou escrita em práticas sociais, sejam elas na escola, nos ambientes profissionais ou nas esferas de inter-relação subjetivas.

Inicialmente, a primeira ação no sentido de adquirir condições de usar a leitura e a escrita como prática social é aprender, efetivamente, a dominar o código. Ler é um processo contínuo que propicia a proximidade com a interpretação; mas essa interpretação tem variações significativas em termos de origens socioculturais, segundo Gumperz (2002). Para Kleiman, ler e escrever são ferramentas poderosas que constituem um indivíduo e é a escola um dos principais espaços institucionais onde acontece a aquisição desse código:

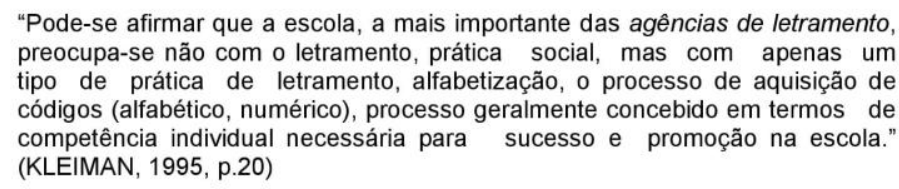

"Pode-se afirmar que a escola, a mais importante das agências de letramento, preocupa-se não com o letramento, prática social, mas com apenas um tipo de prática de letramento, alfabetização, o processo de aquisição de códigos (alfabético, numérico), processo geralmente concebido em termos de competência individual necessária para sucesso e promoção na escola." (KLEIMAN, 1995, p.20)

Como existem vários modos diferentes pelos quais representamos nossos usos e sentidos de ler e escrever, em variados contextos sociais, e como o testemunho histórico de sociedades e épocas distintas representam esses modos, é errôneo pensar em uma coisa singular e compacta chamada letramento. Para Street (1984), a noção de que a aquisição de um letramento único e autônomo terá consequências previstas para os indivíduos e as sociedades provou ser um engano, quando foi quase sempre baseado em valores específicos e culturalmente sobre o que é propriamente o letramento. Em outras palavras, o autor define o letramento segundo duas perspectivas: a autônoma e a ideológica. Sugere que o letramento, na concepção autônoma, um produto completo em si mesmo, que não está preso ao contexto de sua produção para ser interpretado.

Tratando desse modelo, pode ser dito que o processo de interpretação estaria determinado pelo funcionamento lógico interno ao texto critico, não dependendo das (nem refletindo, portanto) reformulações estratégicas que caracterizam a oralidade. 
Segundo este autor, o modelo (autônomo) disfarçaria as suposições culturais e ideológicas, fazendo com que o letramento se apresente como algo neutro e universal capaz de promover estes benefícios. O modelo autônomo impõe concepções ocidentais de alfabetização/letramento de uma para outras culturas, ou dentro de um país, ou ainda de uma classe ou grupo cultural sobre outros. Para se contrapor a esta visão, o autor sugere o modelo ideológico, que oferece uma visão culturalmente mais sensivel das práticas de alfabetização/letramento, contemplando a variação destas de um contexto a outro.

Este modelo propõe não apenas a aquisição neutra de habilidades técnicas, mas uma prática social que sempre está implícita nos princípios epistemológicos socialmente construídos. Os modos pelos quais as pessoas fazem uso da leitura e a escrita são atrelados a concepções de conhecimento, identidade e modos de ser e estar. Estes estão sempre incluídos em práticas sociais, em um mercado de trabalho específico ou em um contexto educacional particular e os efeitos de aprender será dependente destes contextos. Alfabetização/letramento, neste sentido, pode ter um ar competitivo em seus significados e suas práticas, consequentemente, são versões particulares e, portanto, sempre "ideológicas".

Letramento é o uso inicial da ferramenta alfabética, ou seja, um código. Ler é uma competência ampla, diversificada, que está ao alcance de um bebê de meses de vida tanto quanto de um idoso experiente. As várias situações cotidianas e também as mais incomuns são cenários que possibilitam esse exercício de letramento contínuo, multifacetado e a qual as pessoas se expõem nas mais diversas ocasiões. Paralelo a isso acontece, teoricamente, o processo de aquisição dos códigos de leitura e escrita, sendo esse um processo que recebe muitas influências de acordo com sua concepção e que pode, então, favorecer uma incursão por diversos espaços de letramento.

Mas o que inicialmente é visto como nocivo para a aquisição de uma prática de leitura e escrita plena pode, dependendo do empenho pessoal e do meio social, tornarse um obstáculo transponível se pensarmos em termos práticos. Ideologicamente falando, seria ideal que o processo de aquisição das habilidades que envolvem a leitura e a escrita considerasse posturas críticas e sociais, mas, já que na maioria das realidades escolares não é isso que acontece, que, minimamente, o indivíduo se capacite como leitor e escritor, pois, a partir da aquisição dessa capacitação meramente funcional, existe a possibilidade de esta tornar-se um instrumento crítico que pode levar à transformação do discurso (Kleiman, 1995). 
A capacidade de ler como ação funcional pode ser expandida para leituras de mundo, de realidades, favorecendo então a concepção problematizadora de educação, da qual fala Freire (1987): a "educação problematizadora se faz, assim, um esforço permanente através do qual os homens vão percebendo, criticamente, como estão sendo no mundo com que é em que se acham".

Quando Lemos (2002) expõe que o sujeito será resultado de sua atividade no meio social, é preciso arrefecer alguns impulsos que conflitam com a instrumentalização desse sujeito, ou seja, não depositar as esperanças somente na capacitação pura e simples, mas torná-la realmente eficiente ao ponto de esta transformar-se no incentivo real e concreto para um estágio mais subjetivo e importante, que é o letramento no seu aspecto reflexivo, questionador. Como a educação de que fala Freire (1987), a problematizadora, comprometida com a libertação, se empenha na desmitificação.

E seu conceito seguinte, o da concepção, servindo à libertação, se funda na criatividade e estimula a reflexão e a ação verdadeiras dos homens sobre a realidade, responde à sua vocação, como seres que não podem autenticar-se fora da busca e da transformação criadora, em que esta educação, em que educadores e educandos se fazem sujeitos do seu processo, superando o intelectualismo alienante, superando o autoritarismo do educador "bancário", superando também a falsa consciência do mundo. Não cabe, de modo algum, numa realidade de cárcere, uma educação tradicional e alienante. Mais do que em qualquer outra circunstância, é preciso suscitar um ambiente onde caiba a reflexão, o diálogo e o aprendizado mútuo. Diante da realidade atual no campo da educação, é preciso abrir um pequeno parêntese.

É imperativo examinar o que Giroux (1997) chama de as forças ideológicas e materiais que têm contribuído para o que prefiro chamar de proletarização do trabalho docente, isto é, a tendência de reduzir os professores ao status de técnicos especializados dentro da burocracia escolar, cuja função, então, torna-se administrar e Implementar programas curriculares, mais do que desenvolver ou apropriar-se criticamente dos currículos que satisfaçam objetivos pedagógicos específicos. 
A intenção é que, ao invés de refletir sobre os princípios que abordem a vida e prática em sala de aula, professores aprendem metodologias que parecem negar a própria necessidade de pensamento crítico. Em vez de aprenderem a levantar questões acerca dos princípios que subjazem aos diferentes métodos didáticos, técnicas de pesquisa e teorias da educação, os estudantes com frequência preocupamse em aprender o "como fazer", "o que funciona", ou o domínio da melhor maneira de ensinar um "dado" corpo de conhecimento.

O que importa é que o professor não perpetue a ideologia que afasta os alunos da reflexão e da aquisição do senso crítico. É nessa linha de pensamento que caminha este trabalho monográfico: desenvolver, através do letramento, a construção da autoria, do valor da memória, legitimando a identidade dessa narrativa. Mais uma vez, segundo Giroux:

"A noção de que os estudantes têm histórias diferentes e incorporam experiências, práticas linguísticas, cultura se talentos diferentes é estrategicamente ignorada dentro da lógica e contabilidade da teoria pedagógica administrativa." (GIROUX, 1997, p. 161)

Em outras palavras, os estudantes armazenam e distribuem informações, mas também fazem repercutir, sob diferentes níveis e formas, os modos contemporâneos de ver e sentir, gerando influências e tendências. A não sincronia entre esses conhecimentos e a escola pode ser o que define o que acontece em grande parte das escolas nos ciclos fundamental e médio, mediante os meios de comunicação e das novas tecnologias. Na realidade prisional, isso é um conjunto de recursos com uma recepção ainda um pouco resistente, dado que as modificações pedagógicas chegam ainda mais lentamente no ambiente dessa realidade, e há, por isso, uma resistência natural dos alunos ao uso de tecnologias como ferramentas cognitivas.

É fato notório que hoje os meios de comunicação passaram a funcionar como mediadores dos processos educativos, quer formais, quer informais, como a escola deixou de ser a exclusiva agência de promoção educacional. As agências sociais de formação descentraram-se e tenderão a intensificar cada vez mais as possibilidades de se obter informações e mesmo conhecimentos por meio de mecanismos até há pouco privativos do espaço escolar, Citelli fala que: 


\begin{abstract}
"A escola, enquanto instituição privilegiada no contexto da formação da sociabilidade, deve otimizar o seu papel, ampliando o conceito de leitura e aprendizagem, equipando- se para entender melhor os significados e os mecanismos de ação das novas linguagens, inferindo para tratar as mensagens veiculadas pelos meios de comunicação de massa à luz do conceito de produção dos sentidos, algo que se elabora por uma série de mediações e segundo lugares específicos de constituição, que incluem interesses de grupo, valores de classe, simulacros, máscaras, etc." (CITELLI, 2001, p.35)
\end{abstract}

Ou seja, a leitura é a alavanca maior em todos os processos de letramento e é preciso que a escola se arme dessa ferramenta para ressignificar e legitimar os novos processos de aquisição prática da leitura e da escrita, estabelecendo pontes com as impressões que o uso cotidiano com essas ferramentas pode possibilitar.

Voltando às escolas como (ainda) agências representativas de produção de conhecimento, elas precisam ser concebidas como locais cujos perfis econômicos, culturais e sociais que estão inextrincavelmente atrelados às questões de poder e controle e que precisam de profissionais dotados de resiliência para combater a imposição de uma educação meramente formativa e que se torna, por conta disso, incipiente e deformativa.

O resultado de uma formação que incluiria um ambiente leitor, práticas de leitura reflexiva, descoberta e permanência da leitura em outras agências sociais além da escola, uma formação com senso de cidadania e capacidade crítica englobariam as condições ideais de aquisição do letramento como prática. Secundarizando qualquer metodologia, essas práticas, que não precisam de recursos faraônicos ou de tecnologia de ponta, residem em usar o cotidiano como ferramenta de reflexão diária, terapêutica, extraída de recursos ao alcance de qualquer profissional de educação de anos iniciais. Elementos da natureza, pequenas histórias e experiências pessoais trazidas ao grupo são ótimas ferramentas para esse uso. Isso, segundo Soares (2000) funcionaria para que o aluno atrele, de início, ao seu processo de alfabetização a função mor que essa capacitação deve propiciar que é a decodificação interpretativa, que recai sobre a definição de letramento como prática social efetiva:

"(...) o ideal seria alfabetizar letrando, ou seja: ensinar a ler e escrever no contexto das práticas sociais da leitura e da escrita, de modo que o indivíduo se tornasse, ao mesmo tempo, alfabetizado e letrado." (SOARES, 2000, p. 47) 
Essa fala só corrobora a constatação, que já se confirmou como ilibada, de que não é o domínio do código pura e simplesmente que forma o leitor, mas sim a aplicação desse código para assimilação de ideias, conceitos, caminhos a serem avaliados - a ferramentação da prática pelo processo.

A ideia de que as práticas de letramento são constitutivas de identidades fornecenos uma base diferente para compreender e comparar as práticas de letramento em diferentes culturas, alternativa à ênfase corrente numa simples dicotomia letramento/não-letramento, em necessidades educacionais como inevitavelmente endêmicas ao letramento e no tipo de letramento associado com uma pequena subcultura acadêmica, com seu destaque ao texto ensaístico e à identidade típica a ele associada. Na nossa proposta de trabalho, o uso da leitura de textos, poemas, músicas foi fator de bastante influência para o surgimento da curiosidade e interesse dos alunos apenados quando se sentiram capazes de se perceberem intérpretes desse processo de leitura, e donos de suas impressões, como pode ser constatado através da afirmação de Lemos quando diz:

\begin{abstract}
"A leitura como experiência implica ler uma palavra tal como nunca foi lida pois sua significação será construída no instante da leitura, a partir dos conhecimentos presumidos do leitor e de sua interação com o texto lido. Portanto, compreendo que, à medida que atribuímos novos significados para as palavras lidas, internalizamos essas contribuições e nos formamos, nos transformamos e nos deformamos. Enfim, produzimos novos sentidos para nossa formação como sujeitos." (LEMOS, 2002, p. 121)
\end{abstract}

\title{
I.2 Alfabetização: o primeiro passo?
}

Cresce com um ser humano ainda na infância, se este tem algum universo de leitura e escrita à sua volta, a necessidade de conhecer o código que estabelece uma ponte entre ele e aqueles símbolos que se transformam em algo com algum significado. A especificidade da alfabetização está em sua importância na escola e nos espaços em que se empregue a mesma proposta - ao lado do letramento.

O que pode ser chamado de acesso ao mundo da escrita, num sentido maior, é o processo de um indivíduo entrar nesse mundo, e isso se faz inicialmente de duas maneiras, sendo uma, delas através do aprendizado de uma "técnica", a escrita. 
Aprender a ler e a escrever envolve relacionar sons com letras, fonemas com grafemas, para codificar ou para decodificar. Envolve, também, aprender a segurar um lápis, aprender que se escreve de cima para baixo e da esquerda para a direita; enfim, envolve uma série de aspectos que são de cunho técnico. Essa é, então, uma porta de entrada indispensável.

Uma outra via, ou porta por onde se pode ingressar, consiste em desenvolver as práticas de uso dessa técnica. Não adianta aprender uma técnica e não saber usá-la. Essas duas aprendizagens - que consistem em aprender a técnica, o código (decodificar, usar o papel, usar o lápis, observar a disposição de um quadro de escola) e aprender também a usar isso nas práticas sociais, as mais variadas, que exigem o uso de tal técnica - constituem dois processos, e um não está antes do outro.

Estes processos são simultâneos e interdependentes, pois todos sabem que a melhor maneira de aprender com a tecnologia é no próprio uso. Ao se aprender uma coisa, passa-se a aprender a outra. São, na verdade, processos indissociáveis, mas diferentes, em termos de processos cognitivos e de produtos, como também são diferentes os processos convencionais da leitura e da escrita e das relações fonema/grafema, do uso dos instrumentos com os quais se escreve, não sendo prérequisito para o letramento, porque as duas aprendizagens se fazem ao mesmo tempo, uma não é pré-requisito da outra. Mas, por outro lado, se a alfabetização é uma parte constituinte da prática da leitura e da escrita, ela tem uma especificidade, que não pode ser desconsiderada.

Pelos constantes medidores oficiais do desempenho da escola na nossa realidade, enfatiza-se o fraco desempenho dos alunos em suas interpretações textuais ou em suas respostas em que o uso da escrita é avaliado. Como isso se explica, se os processos são concomitantes? Como é possível, se quem aprende a ler e a escrever o aprende com proficiência?

É sobre essa proficiência de leitura e escrita obtida com a alfabetização a que se refere amplamente Soares (2003), quando se pronuncia em relação ao que se tornou a negação dos métodos de alfabetização a partir do momento em que se estimulou o abandono e o esquecimento, até o desprezo, à especificidade desse processo. A alfabetização é algo que deveria ser ensinado de forma sistemática, ela não deve ficar "diluída" no processo de letramento. Pode-se acreditar que essa é uma das principais causas do que vemos acontecer hoje, que é a precariedade do domínio da leitura e da escrita pelos alunos. 
Onde e quando aconteceu, exatamente, a perda da especificidade da alfabetização? O que poderíamos levantar como hipótese é uma concepção de alfabetização que, coincidentemente, chegou ao Brasil na mesma época que o conceito de letramento, nos anos 80 ; seguindo, uma nova organização do tempo da escola, que consiste na divisão em ciclos, trazendo junto a questão da progressão continuada - da não-reprovação. Essa concepção de alfabetização está, de certo modo, atrelada ao conceito de construtivismo. Não que a concepção construtivista seja errada, mas a maneira como ela se difundiu no sistema escolar e educacional é que pode ser uma das causas da perda de especificidade do processo de alfabetização. A mudança conceitual que veio dos anos $80 \mathrm{fez}$ com que o processo de construção da escrita pela criança passasse a ser feito pela sua interação com o objeto de conhecimento. Interagindo com a escrita, a criança vai construindo o seu conhecimento, vai construindo hipóteses a respeito da escrita e, com isso, vai aprendendo a ler e a escrever numa descoberta progressiva.

Na conferência proferida durante o Seminário "Alfabetização e letramento em debate"1 , Mortatti* manifesta-se sobre os sentidos da alfabetização. Atrelada a essa mudança de concepção, veio a ideia de que não seria preciso haver método de alfabetização. A proposta construtivista é válida, pois é assim mesmo que as pessoas aprendem, não somente no que se diz respeito a ler e escrever, mas é assim que se aprende qualquer outra coisa: interagindo com o objeto de conhecimento. Da mesma maneira, não deve ser subestimado o papel desempenhado pelas cartilhas, que, dada sua condição de instrumento privilegiado de concretização dos métodos e conteúdos de ensino, permanecem no tempo e permitem recuperar aspectos importantes dessa história, contribuindo significativamente para a criação de uma cultura escolar e para a transmissão da ou das tradições no ambiente escolar.

1 Conferência proferida durante o Seminário "Alfabetização e letramento em debate", promovido pelo Departamento de Políticas de Educação Infantil e Ensino Fundamental da Secretaria de Educação Básica do Ministério da Educação, realizado em Brasília, em 27/04/2006.

*Professora Livre-docente - FFC-UNESP-Marilia; coordenadora do Grupo de Pesquisa "História do Ensino Professora Livre-docente - FFC-UNESP-Marilia; coordenadora do Grupo de Pesquisa "Historia do Ensino
de Lingua e Literatura no Brasil"; autora de: Leitura, literatura e escola: sobre a formação do gosto (Martins Fontes); Em sobressaltos: formação de professora (Ed. Unicamp); Os sentidos da alfabetização (São Paulo1876/1994) (Ed. Unesp); Educação e letramento (Ed. Unesp) 
Torna-se possível pensar que, no processo desse complexo movimento histórico da alfabetização no Brasil, marcado pela questão dos métodos, independente das mudanças efetivamente ocorridas, o desejado rompimento com a tradição se processa, muitas vezes, dentro de um quadro de referências ligadas ao tradicional e apenas indicando a continuidade, no tempo, de determinados ideais calcados na concepção de educação como esclarecimento - fim esse não atingido, que permanece como parâmetro primeiro a demandar ajustes e meios cada vez mais em busca de serem eficazes - em cujo âmbito se vai consolidando o interesse pela alfabetização como área estratégica e cada vez mais autônoma (ainda que limitada) para a objetivação de projetos políticos e sociais decorrentes de urgências de cada época. Ao mesmo tempo, vão-se produzindo reflexões e saberes que configuram o movimento de escolarização do ensino e aprendizagem da leitura e escrita e de sua constituição como objeto de estudo/pesquisa, evidenciando a alfabetização como o signo mais complexo da relação problemática entre educação e modernidade, estabelecendo o vínculo atual entre o processo de alfabetização e suas aplicações à luz do letramento.

Enquanto suposto e prometido resultado da ação da escola e enquanto rito de iniciação na passagem do mundo privado para o mundo público da cultura e da linguagem, o ensino e a aprendizagem da língua escrita na fase inicial de escolarização de crianças e também de adultos, em realidade diferentes, se torna índice de medida e testagem da eficiência da ação modernizadora da educação contra a ausência de civilidade.

No caso dos alunos, seu processo de leitura e escrita está, quase que invariavelmente, associado a esse perfil de aluno que domina precariamente um código e que por conta disso, não faz aplicações práticas do mesmo. É preciso então estreitar os laços daqueles alunos com a leitura para tentar desenvolver o vínculo que os fará nesse processo de descoberta da leitura como instrumento de comunicação, se sentir capaz de contar sua própria história e tornarem-se narradores de si mesmos e de seu aprendizado.

É importante propiciar situações de leitura para que aconteça o que afirma Albuquerque (2008), em seus estudos sobre as cartas de Foucault, quando diz que o leitor, ele mesmo, interpreta os textos conforme sua maneira de entender a si mesmo e aos outros, na medida em que se vai construindo uma prática intersubjetiva. 
E aprendi também que método bom é aquele que funciona, ou seja, a metodologia boa é a que faz a interação do conteúdo entre professor e aluno, em que há a aquisição do conhecimento, desde que ele seja aplicado com coerência e fazendo as pontes necessárias para ampliar a capacidade cognitiva dos alunos nas diversas áreas integradas de ensino. Porque o que traz sucesso a essa "receita" é a prática, o uso, a aplicação e aprimoramento da técnica de ler e escrever para sempre e infindavelmente. Ou seja, fazer dessa prática a ferramenta para, ao ler mais, cada vez escrever melhor.

Segundo Brandão (2008), são três os passos necessários para que esse mecanismo de cognição se complete: $1^{\circ}$ passo - a codificação de informações: elas chegam ao cérebro através dos órgãos dos sentidos; $2^{\circ}$ passo - 0 armazenamento das informações: elas são codificadas, estruturadas e armazenadas no cérebro (em diferentes áreas); $3^{\circ}$ passo - a manutenção e recuperação das informações: transformação das informações em lembranças permanentes, passíveis de recuperação, e, por conseguinte, uso e aplicação.

Diferentes letramentos, portanto, são associados a diferentes pessoas e identidades. Conjuntos semelhantes de associações podem ser vistos nesta cultura, uma vez reconhecida a importância do letramento para tais processos. Quando frequentamos um curso ou uma escola, ou nos envolvemos num novo quadro institucional de práticas de letramento, por meio do trabalho, do ativismo político, dos relacionamentos pessoais, etc., estamos fazendo mais do que simplesmente decodificar um manuscrito, produzir ensaios ou escrever com boa letra: estamos assumindo - ou recusando - as identidades associadas a essas práticas.

\section{II - SOU O QUE LEMBRO}

\section{II.2 Memória}

Memória é o que nos faz lembrar de uma determinada história ocorrida no passado, também é como deixamos fluir naturalmente as frases complicadas de algumas músicas e canções; também é o que nos faz nunca esquecer como se anda de bicicleta. Nestes exemplos, a memória surge como um processo de retenção de informações no qual nossas experiências são arquivadas e recuperadas quando as chamamos. É uma função cerebral superior relacionada ao processo de gravação de informações obtidas em experiências vividas. 
A memória individual é sempre diferente. Cada um lembra de um jeito diverso, segundo o que the interessa e o que amealhou durante a experiência. A seleção da memória nos faz perceber o que é útil e importante para alguém. E esse processo contínuo de seleção só é possível por conta do filtro da cultura. Mas há também uma memória coletiva que é aquela formada pelos fatos e aspectos julgados relevantes e que são guardados como memória oficial da sociedade mais ampla.

O termo memória tem sua origem etimológica no latim e significa a faculdade de reter e/ou readquirir ideias, imagens, expressões e conhecimentos adquiridos anteriormente reportando-se às lembranças, reminiscências. Outra definição do termo memória é apresentada por Brandão (2008) quando fala que a origem da palavra remete à mitologia greco-romana, mais precisamente à deusa Mnemósine, personificação da memória ou lembrança, filha do Céu e da Terra, irmã de Cronos - o deus que preside o tempo - e mãe das Musas, que com ela regiam as artes e todas as formas de expressão, especialmente a poesia:

“(...) memória é aquisição, conservação e evocação das informações, dos fatos vivido s por cada indivíduo, e que a formação quanto sua extinção - os esquecimentos - são vinculados a um sistema complexo." (BRANDÃO, 2008, p.8)

Assim sendo, memória é basicamente a capacidade humana de inscrever, conservar e relembrar mentalmente vivências, conhecimentos, conceitos, sensações e pensamentos experimentados em um tempo passado. Especialistas da Neurobiologia e da Psicologia Cognitiva ratificam esta definição, afirmando que, na verdade, existem várias memórias, pois há diversas fontes de armazenamento de dados em nossa mente, não limitadas em uma área determinada de nosso cérebro, mas inerentes a distintas atividades mentais:

"Arquivar a própria vida é se pôr no espelho, é contrapor à imagem social a imagem íntima de si próprio, e nesse sentido o arquivamento do eu é uma prática de construção de si mesmo e de resistência." (ALTIĖRES, 1998, p.11)

Seja assim ou como for, porém, que a memória se expresse, os especialistas são unânimes em afirmar que ela é o fundamento do desempenho cognitivo do homem. Ela exige, para sua melhor performance, um alto dispêndio de energia mental, e se adultera com a passagem do tempo. Seu mecanismo age como uma espécie de colagem de fragmentos mnemônicos e de conhecimentos, que dá vida a ideias originais. 
Nossa memória tem níveis diferentes de conservação temporal dos dados adquiridos. Alguns deles se esvaem com a passagem dos anos, outros se tornam mais difíceis de detectar, enquanto determinadas informações ficam meio apagadas e são arduamente reconstituídas. Essa é mais uma prova de que existem vários tipos de memórias, o que transforma seu estudo em algo complexo, que exige um esforço transdisciplinar, abrangendo pesquisas neurofisiológicas, bioquímicas, moleculares e emocionais.

Hoje a memória está dividida essencialmente em dois tipos, conforme sua extensão no tempo, as atividades do cérebro envolvidas no processo, o grau de conservação, seu teor e os mecanismos neurológicos incluídos nesta operação.

O primeiro tipo é a memória declarativa, através da qual se retém na mente a ideia de saber que algo aconteceu; o segundo é a memória de procedimentos ou não declarativa, que conserva a noção de como se deu este evento. Enquanto os psicólogos e neurologistas preferem se dedicar ao estudo da memória declarativa, os neurobiólogos se concentram nesta última categoria.

A memória declarativa, focalizada no dom humano de expor verbalmente acontecimentos, está submetida à prática da recordação, e é subdividida em memória imediata - que tem duração instantânea, sendo logo em seguida extinguida -; memória de curto prazo ou de trabalho, como prefere a psicologia cognitiva - leva algumas horas para desaparecer, legando à mente alguns vestígios de sua presença, apenas o necessário para ser lembrado e empregado utilmente pelo homem, e está conectada às nossas emoções, sensações e costumes -; memória de longo prazo - engloba intervalos de tempo mais amplos, meses ou anos.

A memória de procedimentos, centrada no potencial mental de guardar e reunir dados que não podem ser expressos oralmente é mais duradoura, fácil de ser conservada.

Estas são as categorias principais, mas outros tipos podem ser incluídos nesta distribuição por classes, como as implícitas e explícitas, adotadas principalmente pelos terapeutas cognitivos. Ambas se reportam ao poder de recordar ideias conservadas nas memórias acima abordadas. 
Já os psicólogos percebem outros dois tipos de memórias - a episódica, ligada à evocação de fatos específicos, inerente ao cenário espaço-temporal, pois determina quando, onde e como ocorreram determinados eventos; e a semântica, associada aos aspectos gerais dos eventos, capaz de guardar dados concretamente adquiridos, como conceitos, aptidões, acontecimentos e racionalizações.

Esta fascinante faculdade mental forma a base de nosso conhecimento, estando envolvida com nossa orientação no tempo e no espaço e nossas habilidades intelectuais e mecânicas.

Quando vamos ao encontro do passado por meio da memória, partimos do presente - do hoje que partimos em direção ao passado, trazendo conosco a memória dos tempos: um tempo externo, Chronos - objetivo, histórico, datado, irreversível; e um tempo interno, Kairós - subjetivo, vivido, reversível, sendo esse último, também, o tempo do mito, do místico, das religiões - um tempo circular - que, a cada narrativa, reinicia o ciclo e o círculo que dá novo significado, e o mantém.

Se somos aquilo que lembramos e esquecemos, vislumbramos novos caminhos e a abertura para reflexão e compreensão de como se constrói uma cultura, no seu sentido amplo, e como nelas as memórias, nos tempos, podem ser um remédio diante do que podemos chamar apropriadamente de desencantamento da existência, nesse panorama complexo da "modernidade líquida" ${ }^{2}$ - leve, fluída, dinâmica, mas inexoravelmente, incerta.

A memória é uma faculdade cognitiva extremamente importante porque ela forma a base para a aprendizagem. Se não houvesse uma forma de armazenamento mental de representações do passado, não teríamos uma solução para tirar proveito da experiência. Assim, a memória envolve um complexo mecanismo que abrange o arquivo e a recuperação de experiências, portanto, está intimamente associada à aprendizagem, que é a habilidade de mudarmos o nosso comportamento através das experiências que foram armazenadas na memória; em outras palavras, a aprendizagem é a aquisição de novos conhecimentos e a memória é a retenção daqueles conhecimentos aprendidos.

Assim, aprendizagem e memória são o suporte para todo o nosso conhecimento, habilidades e planejamento, fazendo-nos considerar o passado, nos situarmos no presente e prevermos o futuro.

${ }^{2}$ Conceito de Zygmunt Bauman 
Neste trabalho, a proposta aos alunos é que disponham suas lembranças (memórias) de determinados temas para que eles estabelecessem contato com suas histórias pessoais em um processo de aproximação com as mesmas. A intenção é a de que se enxerguem como agentes ativos dessa tarefa, habilitando aquilo que Brait (1997) chama de consciência, sendo uma capacidade, ou melhor, um poder de síntese, uma atividade que reconhece ou que reproduz, a partir de si mesma o sentido do real, pela produção de ideias ou conceitos dos objetos e dos estados interiores. Estas atividades epistemológicas e esse poder definem aquilo que a Filosofia denomina o Sujeito.

\section{II.2 Memória como identidade}

(...) somos aquilo que pensamos, amamos, realizamos, (...) somos aquilo que lembramos. (Norberto Bobbio)

Usando o pressuposto que a "memória é a faculdade de reter ideias ou reutilizar sensações, impressões ou quaisquer informações adquiridas anteriormente" como afirma o dicionário da Língua Portuguesa (FERREIRA, 1989,334), percebe-se que essa memória proporciona lembrar da própria lembrança e não deixa que se apaguem as experiências adquiridas por todos envolvidos com aquele episódio.

De um lado, temos as condições neurobiológicas que permitem a formação e a consolidação das memórias; por outro, a emoção que acompanha o fato que foi vivido, sem a qual não haveria essa chamada consolidação e, portanto, a possibilidade de resgate ou rememoração. Nada somos além daquilo que lembramos, mas também daquilo do que esquecemos, sejam essas lembranças as silenciadas (voluntária ou involuntariamente), sejam os não ditos. Dizendo de outra maneira, somos o que lembramos, mas também o que não podemos ou queremos falar.

A memória é sempre atual, pois a qualquer momento podemos evocá-la. É vivida no eterno presente, aberta à dialética da lembrança e do esquecimento; alimenta-se de lembranças vagas, telescópicas, globais e flutuantes, e cria sentimento de pertencimento e identidade. Associa-se a fatores sociais e transforma-se em discurso real quando solicitada. A memória é o "meu ser" pessoal em um coletivo. 
A memória do grupo, sendo a marca ou sinal de sua cultura, possui algumas evidências bastante concretas. A primeira e mais penetrante dessas finalidades é a da própria identidade. A memória do grupo baseia-se essencialmente na afirmação de sua identidade. A memória é um elemento constituinte do sentimento de identidade, tanto individual como coletiva, na medida em que ela é também um fator extremamente importante do sentimento de continuidade e de coerência de uma pessoa e/ou de um grupo:

\begin{abstract}
"A memória não pode ser entendida como apenas um ato de busca de informações do passado, tendo em vista a reconstituição deste passado. Ela deve ser entendida como um processo dinâmico da própria rememorização, 0 que estará ligado à questão de identidade." (SANTOS, 2004, p.59)
\end{abstract}

Assim como a memória não é só um recurso de consulta do passado, Halbwachs (2004) vai além quando diz que um indivíduo que lembra é sempre um indivíduo inserido e habitado por grupos de referência. A memória é sempre constituída em grupo, mas é, também, um trabalho do sujeito. E segundo Altières (1998), tudo passa pelo escrito; assim sendo, a memória precisa ser uma ação de registro para se instituir história, pessoal e incógnita ou socializada e difundida, pois nela coabitam as histórias formativas de outros, a coadjuvância de quem fez parte de nossa história.

Diversas experiências nos mostram que, a partir da memória autobiográficas podemos usar a linguagem, refletir, compreender, reorganizar, e ressignificar essas trajetórias e projetos de vida-trabalho, nossas e de outros, articulando as memórias individuais e coletivas, dando-lhes um sentido e significado. Essa história, que é nossa e dos grupos aos quais pertencemos, diz-nos quem somos; auxilia e fortalece nossa identidade, ilumina nosso caminho na busca de sentidos para nosso bem estar no mundo. Como também essas mesmas atividades de socialização de histórias servem como ponte para levar essas histórias para o universo escrito e possibilitando o que esse trabalho se propõe: ajudar esses homens a se enxergarem em de seus relatos, confrontando-se com suas memórias como acervo pessoal dos fatos vividos ao longo da própria vida, passíveis de serem recuperados, chamados pelo presente, um maravilhoso e intrigante processo - envolvendo o resultado das interações cognitivas acrescidas de emoção, motivação e desejo - levando-os à consolidação, ou seja, torná-los uma história a ser escrita e trazer-Ihes a consciência da capacidade criativa em outras áreas de conhecimento. 
Ao mesmo tempo em que a proposta de identificação com a própria escrita narrativa vai se desvelando, acompanha a proposta de prestar atenção nas influências de memória ao entorno dessa própria história: a influência local, a presença da família, as condições sociais envolvidas, porque a lembrança pessoal, de cada um, é constituída, muitas vezes, com elementos não realmente vividos pelo indivíduo, mas apropriados e incorporados a partir dos relatos dos pais, tios, avós, entre outros, sobre fatos vividos no seio da família e, posteriormente, ao longo da vida dos diferentes grupos sociais dos quais todos fazem parte.

Toda a lembrança, mesmo tida pelo indivíduo como particularmente sua, prendese de alguma maneira ao contexto social mais amplo, reafirmando a ideia de que "nunca estamos sós", ou seja, construímos nossas impressões quase que invariavelmente sob a influência de fatores externos. Como somos essencial e necessariamente seres de interação, essa influência se faz de maneira ainda mais incisiva quando carecemos de confrontar nossas impressões com quaisquer outras do universo que de impressões que nos circunda. Assim também são nossas lembranças, que recebem matizes diversos na medida que amadurecem na nossa memória; e não é uma influência que modifique sua essência, mas sim que the propicie novas ou outras leituras.

Considerando como único cada olhar sobre os fatos acontecidos, deve ser somado a todos os olhares focados no mesmo acontecimento, vivido em grupo, o trabalho da história que cataloga, organiza e preserva o tempo passado. Cada uma dessas memórias - individual, coletiva e histórica - por si só não explica ou esgota totalmente suas inúmeras possibilidades de articulação, apontando para a complexidade dessas tentativas de compreensão e organização de sentidos. Daí as várias leituras sobre uma mesma temática e consequentemente, uma riqueza de interpretações. Se isso se faz possível e tem - como realmente tem - valor, esse pensamento foi partilhado junto aos alunos da pesquisa para que servisse de incentivo para o desenvolvimento de suas produções.

\footnotetext{
"Ao recordar, buscamos os sentidos na vida e da trajetória individual, sem esquecer que ela está entrelaçada com as trajetórias grupais, procurando ver os elos da corrente que as une. Ela possibilita aos indivíduos confrontar as incertezas, as mudanças e as rupturas inerentes à existência humana, ampliando a percepção de si e dos outros, constituindo-se assim, a raiz das identidades." (BRANDÃO, 2008, p. 29)
} 
Pode-se também com isso dizer que os sentidos de pertencimento e identidade são ambíguos, de caráter revogável e negociável, e dependem não só de origem, do lugar de destino, do lugar social que ocupamos, mas também das maneiras de pensar, das escolhas feitas e das ações daí decorrentes, evidenciando a fragilidade e a condição sempre provisória das identidades, porque estes sentidos da construção das identidades como processo ambíguo e dinâmico, é passível de ser atualizado e modificado, na construção de um sentido para trajetória de vida, narrada como uma história.

Permite-se entender trajetória de vida o processo de apreensão da realidade da qual cada indivíduo, mergulhado numa cultura social e seus agenciamentos distintos, abstrai e, a partir de sua percepção única, reordena e transforma num projeto, profissão, modo e estilo de vida, podendo passar a ser chamado de trajetória identitária. $O$ indivíduo sofre influência e provoca influência, formando um elo numa corrente sem fim, a que chamamos de saber, em um processo que constrói e dá sentido às memórias individuais e coletivas, e às identidades a elas ligadas.

As memórias que compõem esse trabalho são formadas no entrelaçamento das experiências pessoais e de suas interpretações culturais, podendo formar sentidos, quando indagamos "quem sou eu?" ou "o que eu vivi?" na busca por identidade(s). Constituem, portanto, eventos de letramento, isto é, situações em que a escrita constitui, segundo Kleiman (1995), parte essencial para fazer sentido da situação, tanto em relação à interação entre os participantes como em relação aos processos e estratégias interpretativas.

Para uma prática escolar que visa o domínio da escrita para a produção de um texto expositivo abstrato, internamente consistente, pressupõe-se uma separação polarizada entre a oralidade e a escrita. Para ser coerente com essa concepção, a prática escolar precisa ao menos tentar buscar se fundamentar numa análise das diferenças que decorrem da transmutação de uma mensagem de um meio fônico para o visual, que se centra na fugacidade de uma em contraposto à permanência da outra: assim, a possibilidade de mais planejamento, uma maior potencialidade de revisão e, portanto, de exatidão no texto, a exploração das diversas funções da escrita, como as funções de apoio para a memória, de transmissão de conteúdos, independente das limitações de espaço e do tempo que seriam relevantes nessa proposta. 
Quem fala de si, escrevendo, pretende se fazer ler, seja esse leitor autorizado ou não. Quando nos é solicitada a escrita de alguma memória que nos pertence, está subentendido que essa solicitação se reverterá em partilha. Agrada-nos, de um modo geral, partilhar a nossa escrita, pois, se não desejamos partilhar, simplesmente não escrevemos.

No processo de construção de nossa memória, arquivamos nossa vida de diferentes maneiras: guardando fotos, organizando documentos profissionais ou catalogando nossas contas e compromissos exercidos e cumpridos, escrevemos diários. $\mathrm{Na}$ construção de uma identidade, o indivíduo baseia-se nas suas memórias para dar a essa construção o aspecto de peculiaridade, pois nossas histórias personalizam nossa trajetória.

Pensar a memória como relação entre tempos, espaços e sujeitos abre a possibilidade de que, a partir de uma nova situação ou um novo encontro - como pretende ser a situação analítica, por exemplo -, o passado possa ser tanto recordado quanto reinventado. Desse modo, a história de um sujeito, individual ou coletiva, pode ser a história dos diferentes sentidos que emergem em suas relações. Ou, de outro modo: abre-se a possibilidade de que a memória, ao invés de ser recuperada ou resgatada, possa ser criada e recriada, a partir dos novos sentidos que a todo tempo se produzem tanto para os sujeitos individuais quanto para os coletivos - já que todos eles são sujeitos sociais. A polissemia da memória, que poderia ser seu ponto falho, é justamente a sua riqueza, onde não cabe juízo de valor ou de verdade, cabe sua autenticidade enquanto relato voluntário.

Como afirmou Bakhtin (2000), todas as esferas da atividade humana, por mais variadas que sejam, estão sempre relacionadas com a utilização da língua; e a utilização da língua acontece em forma de enunciados (orais e escritos), concretos e únicos, que emanam dos integrantes de uma ou de outra esfera da atividade humana. Por isso acho que cabe considerar que os relatos transcritos com a intenção de serem memórias são a necessidade que o ser humano tem de testemunhar sua existência, tornar pública sua trajetória; na mesma medida que esta construção de memória enquanto arquivamento é, com efeito, um desejo de tomar distância em relação a si próprio. Isso possibilitaria uma "leitura externa" de si, como se fosse uma visão hipoteticamente imparcial com os fatos ali registrados. 
Quando o escritor se torna o personagem de observação e, assim, permite uma interpretação de si mesmo, nesse momento, ficou registrado o prazer e a saudável vaidade de ser protagonista de um relato. Como recomenda Altières (1998), devemos controlar nossas vidas, e isso incide em que nada pode ser deixado ao acaso; devemos manter arquivos para recordar e tirar lições do passado, para preparar o futuro, mas sobretudo para existir no cotidiano.

É necessário construir uma proposta de trabalho em que eles se familiarizem com a prática de olhar para si sob uma lente de análise, olhar esse despojado das agruras do apartamento social da prisão, pois a intenção é ver o homem e sua capacidade de resgate e agrupamento de suas vivências e percepções associadas às suas experiências. A partilha dos relatos enriquece as próprias experiências de cada um e estimulam a exposição pessoal, facilitando assim a expressão escrita. Lemos (2002) afirma que a construção de um autorretrato inclui a internalização das palavras alheias sobre a pessoa que se retrata, sendo, por isso, o autorretrato um material fluído e dinâmico, pois se encontra em permanente reconfiguração de suas formas, pensamentos e valores

O sujeito necessita do outro para se diferenciar e construir o acabamento de si próprio, pois a experiência que tem de si nunca propiciará uma visão delimitada de sua configuração externa. Ele precisa de outros olhares sobre si para se construir mesmo.

Fabrício (2010) afirma que o discurso é uma prática social que leva à construção e à atribuição de significado à experiência e aos atores sociais por meio dos posicionamentos interacionais que eles ocupam no uso da linguagem. Por conta da importância dos discursos educacionais na construção de quem somos, somado principalmente à quantidade de tempo que passamos na escola e ao fato de que os contextos escolares são os primeiros que podem apresentar uma opção para os limites discursivos para os que agora são discentes normalmente viveram até ingressarem em tais contextos, as práticas de letramento escolares têm um papel a desempenhar na familiarização dos alunos com os processos implícitos na produção sociocultural das identidades e alteridades. Num processo de lacunas espaçadas, quando possuem até nenhuma frequência dentro de ambientes escolares, é preciso adaptar esse processo à bagagem cultural desses alunos apenados, atípicos, não lineares e que desconhecem, em diferentes escalas, o papel da escola na sua capacitação cognitiva. 
Escrever sobre si era um movimento que, longe da injunção, na verdade, propiciava uma viagem para dentro de si ao encontro do seu próprio passado e que isso era interessante de partilhar; apesar de envolver, em algumas leituras, momentos não muito felizes, é o que Altières (1998) considera como insurgência. Esse arquivamento da própria vida toma a dimensão importante de se fazer conhecer, de deixar um legado feito por aquele que viveu aquilo que está registrado. Também é um processo de remissão, onde o caminho percorrido é revisto com a intenção de se fazer entender as escolhas, a admissão de equívocos e a leitura de suas consequências.

A partilha da memória é um de seus fatores mais importantes para quem a escreve. Não lembramos para nós mesmos somente. Na proposta deste trabalho, a intenção é que fique bem claro que essa partilha nasce da consciência de que a história individual de cada um pode - e merece - ser escrita, favorecendo o aparecimento da autoria. Com isso, nasce a percepção de valor das histórias, percebido no respeito do grupo pelo conteúdo de cada uma, a graça encontrada nas histórias divertidas e o respeito pelo sofrimento que alguns relatos denotam. Nesse caso, também se evidencia a identidade com suas próprias vivências, que poderiam parecer diluídas em um pensamento que concentrava uma espécie de composição coletiva por conta de pertencerem a um segmento da sociedade excluído - mediante sua situação de apenado. É preciso entender que as histórias representam o conjunto de sensações e lembranças; prazeroso no relato desses autores, recordando do que se foi quando criança e como pode ser bom reconstruir essas histórias pela via da memória, não mais como uma luta para se abrigar nelas e esquecer por um pequeno tempo da realidade que é preciso enfrentar cotidianamente, mas como uma fonte de prazer para ser registrado legitimamente, uma identidade que corrobora a formação de quem compõe essas lembranças:

\begin{abstract}
O arquivamento do eu não é uma prática neutra; é muitas vezes a única ocasião de um indivíduo se fazer ver tal como ele se vê e tal como ele desejaria ser visto. Arquivar a própria vida, é simbolicamente preparar o próprio processo: reunir as peças necessárias para a própria defesa, organizá-las para refutar a representação que os outros têm de nós. Arquivar a própria vida é desafiar a ordem das coisas: a justiça dos homens assim como o trabalho do tempo. (ALTIĖRES, 1998, p.31)
\end{abstract}

Para nos identificarmos com alguma coisa sobre a qual escrevemos, é preciso que dominemos, a contento, um código, para que possamos passar, transmitir, determinada mensagem desejada. Para isso, a nossa segurança de domínio desse código precisa estar preservada. 
Isso interfere na escolha das palavras e no destemor com o qual transmitimos as informações que desejamos partilhar. Nesse aspecto, é preciso desenvolver a capacidade de letramento para a escritas das memórias, delegando menos importância aos erros ortográficos que foram suplantados na medida que o conteúdo ganhou importância principal.

\section{ESCREVO SOBRE O QUE SOU}

\section{III.1 Construção da autoria através do letramento}

A primeira dificuldade apresentada por quem reluta em escrever sobre si é a insegurança sobre o próprio escrever, a prática da escrita. $\mathrm{O}$ aspecto técnico, instrumental, é a primeira barreira concreta a ser superada. Segundo Lemos, a linguagem escolar “(...)vem sendo um instrumento de práticas sociais antidemocráticas, pois é
veiculada a partir de uma norma culta que não faz parte do meio
sociocultural das classes populares. Não contempla os diferentes gêneros
discursivos presentes no seu cotidiano e diferenças linguisticas. Não propicia
uma identificação entre as transformações socioculturais que perpassam pela
formação dessas crianças e pelas práticas de linguagem que são trabalhadas
na escola." (LEMOS, 2012, p.115)

Comprovadamente falando, não há nada a favor da gramática tradicional nesse sentido. Pelo contrário, sabe-se que a grande dificuldade é seguir as suas prescrições, consagradas no ensino, mas que causam a inibição de muitos que desejam escrever.

Bagno (1999) afirmou que é necessária a criação de uma nova gramática brasileira, que atente para a verdadeira norma culta falada no Brasil. Para o autor, enquanto distantes dessa inovação, as pessoas precisam de uma mudança de atitude. Usuários comuns da língua precisam rejeitar que a prescrição ilógica da gramática tradicional menospreze seu saber linguístico, e professores precisam assumir uma postura reflexiva perante o ensino de língua, pondo em dúvida, em investigação e levantamento de hipóteses todas as diferenças entre o que a gramática prega e os usos que os falantes fazem da língua no país. Dado o tamanho da comoção que uma nova norma requereria, e diante da que foi realizada para uni(formiza)r um idioma comum entre povos distintos, o mais viável é tentar realizar uma mudança de pensamento que, como uma fonte, transforme-se, de manancial em mar. 
Ainda de acordo com Bagno (1999), é comum o equívoco de classificar "erro de ortografia" como "erro de português". Em seu livro "Preconceito linguístico: o que é, como se faz", este autor elenca dez mitos relativos ao uso da língua portuguesa, e é no sexto mito que ele ressalta que a ortografia é uma convenção cujo rompimento dificilmente prejudica a gramaticalidade de um enunciado. Em outras palavras, os erros verdadeiros estariam na produção de enunciados que desrespeitassem a aceitabilidade, o que os falantes raramente fazem. Diz-se então que, em contrapartida, com a eliminação do conceito de erro, haveria então um total descaso com a língua, uma situação de "vale-tudo".

Mas a língua é um acervo do qual se pode retirar a palavra para qualquer ocasião, tudo depende "de quem diz o quê, a quem, como, quando, onde, por quê e visando que efeito" (p.131). A tal "obsessão ortográfica" por parte de um segmento de professores mostra-se então injustificada, porque o conhecimento da ortografia não possui uma relação direta com o conhecimento da língua. É a qualidade do que é dito (em todos os sentidos) que deve ser analisada. Quando no início do contato com a escola, já acontece uma segregação:

\begin{abstract}
"As bem-sucedidas são as que atendem às expectativas da escola e que, portanto, tiveram uma orientação de letramento compatível com a orientação escolar. As mal sucedidas passam a formar os grupos de risco. O letramento que viveram é ignorado e elas são colocadas em programas que visam reencaminhá-las para o letramento acadêmico desejado pela escola." (TERZI 2001, p.44)
\end{abstract}

Assim, em um processo excludente, o aluno que não domina as habilidades privilegiadas pela escola não é visto conforme seu desenvolvimento, mas conforme o que Ihe falta para atingir o padrão pressuposto pela escola, ou seja, seu déficit. As orientações sociais são instituídas de valor excludente e deve ser porque na escola, enquanto instituição de ensino, espera-se que a comunidade altere sua orientação para adequá-la às normas da escola e não o contrário.

Kleiman (1995) fala que ao mesmo tempo em que a aquisição das novas práticas é percebida como necessária para a sobrevivência e a mobilidade social na sociedade atual, repleta de tecnologia, essa aquisição se constitui no prenúncio do abandono das práticas discursivas familiares, e que o ensino instrumental de leitura deixa de ser meramente funcional para se tornar um instrumento crítico que poderia levar à transformação do discurso. 
Essa mudança, se tem um lado positivo, que é a aquisição da tecnologia da escrita como ferramenta de ascensão e capacitação, tem também o papel de influência na negação da carga dessa cultura popular, das práticas discursivas que carregam histórias e vínculo com raízes do passado.

Como letramento é um fenômeno de muitos significados, ele não pode ser avaliado e medido de forma absoluta. Como não é possível descobrir uma definição indiscutivel e inequívoca de letramento, ou a melhor forma de defini-lo, qualquer avaliação ou medição desse fenômeno será relativa, dependendo de quais habilidades de leitura, ou escrita, ou práticas sociais de letramento estiverem sendo avaliadas e medidas, para quais fins ou propósitos, em que momento e em que contexto socioeconômico e cultural se está avaliando ou medindo, e de acordo com quais critérios é feita a avaliação ou a medição. Outra questão pertinente é que o conceito de letramento varia de acordo com o contexto social, cultural e político. A interpretação adequada de dados sobre letramento requer o conhecimento das definições com a base nas quais foi avaliado e medido e das técnicas de coleta de dados utilizadas:

\footnotetext{
"O letramento é, sem dúvida alguma, pelo menos nas modernas sociedades industrializadas, um direito humano absoluto, independentemente das condições econômicas e sociais em que um dado grupo esteja inserido; dados sobre letramento representam, assim, o grau em que esse direito está distribuído entre a população e foi efetivamente alcançado." (SOARES, 2000, p.120)
}

Junto dessa afirmação, a questão maior dentro da proposta deste trabalho é, junto da aquisição da técnica, a confiança na legitimidade do que está sendo escrito, com o movimento de força voltado para a construção de um indivíduo que produz refletindo, pois todo "pano de fundo" dentro dos ambientes escolares precisa ser voltado para desenvolver um discurso crítico de forma que tanto os educadores como os alunos reconheçam que podem promover mudanças. A aquisição dos conceitos, regras e procedimentos técnicos vem permeando a conquista do letramento, concomitante e na medida que vira práxis: a reflexão e ação dos seres humanos sobre o mundo para transformá-lo. Sem ela, é impossível a superação da contradição opressor-oprimido. É uma ação com reflexão, com retorno.

\footnotetext{
"Tornar o político mais pedagógico significa utilizar formas de pedagogia que incorporem interesses políticos que tenham natureza emancipadora; isto é, utilizar formas de pedagogia que tratem os estudantes como agentes críticos; tomar o conhecimento problemático; utilizar o diálogo crítico e afirmativo; e argumentar em prol de um mundo gradativamente e qualitativamente melhor para todas as pessoas." (GIROUX, 1997, p.163)
} 


\title{
III.2 Os frutos: reflexão sobre a memória
}

\begin{abstract}
Todavia, o homem também se admira de si mesmo por não poder aprender a esquecer e por sempre se ver novamente preso ao que passou: por mais longe e rápido que ele corra, a corrente corre junto. $E$ um milagre: o instante em um átimo está aí, em um átimo já passou, antes um nada, depois um nada, retorna entretanto ainda como um fantasma e perturba a tranquilidade de um instante posterior. Nietzsche, in 'Segunda Consideração Intempestiva'
\end{abstract}

$\mathrm{Na}$ proposta de montar um tipo de memorial adaptado às questões levantadas durante o período em que foi pesquisado esse processo de letramento que deu origem e corpo a este trabalho, foram construídos os textos que me servem de base para a análise. Memorial é um relato que reconstrói a trajetória pessoal, mas que tem uma dimensão reflexiva, uma vez que quem relata se coloca como sujeito que pergunta a si e deseja compreender-se como o sujeito de sua própria história. O memorial, portanto, constitui um exercício de interrogação de nossas experiências passadas para fazer aflorar não só recordações/lembranças, mas também informações que confiram novos sentidos ao nosso presente.

A forma como encaramos certas situações e objetos está impregnada por nossas experiências passadas. Através da memória, não só o passado emerge, misturando-se com as percepções sobre o presente, como também desloca esse conjunto de impressões construídas pela interação do presente com o passado, que passam a ocupar todo o espaço da consciência. Em outras palavras, é que não existe presente sem passado, ou seja, nossas visões e comportamentos estão marcados pela memória, por eventos e situações vividas. O passado atua no presente de diversas formas. Uma delas, chamada de memória-hábito, está relacionada com o fato de construirmos e guardarmos esquemas de comportamento dos quais nos valemos muitas vezes na nossa ação cotidiana. Empregamos, dentro de nossa experiência de vida, essas ações, mas o registro dessas experiências traz uma releitura importante que pode recair em um novo olhar sobre essas impressões e trazer modificações que reescrevam, gerando novas memórias, nossas atitudes.

O Memorial é o resultado de uma narrativa da própria experiência retomada a partir dos fatos significativos que nos vêm à lembrança. Fazer um Memorial consiste, então, em um exercício sistemático de escrever a própria história, rever a própria trajetória de vida e aprofundar a reflexão sobre ela. Esse é um exercício de auto conhecimento. 
O Memorial está intimamente relacionado a um exercício de reminiscência, isto é, de "puxar pela memória". Como a memória é seletiva, filtrada pelo que sentimos e acreditamos, queremos que, no momento de elaboração do Memorial, esta seleção torne-se reflexiva. Ou seja, submetida a um exercício que tem como objetivo trabalhar as experiências que a pessoa considera de maior relevância na sua trajetória, relatando-a de modo reflexivo. Uma boa proposição é tomar as vivências e ir desenvolvendo uma reflexão dessa experiência apontando de que modo isso provocou desdobramentos em outras dimensões de vida. Geralmente a tônica recai muito insistentemente nas práticas que resultaram no apartamento social e os trâmites complexos que pertencem ao ambiente fora da lei. Mas a memória construída não vem "engordurada" de julgamento ou impressões que nos levem ao não procedente julgamento, elas se detêm ao seu papel de lembrança e nos permite a partilha de uma experiência que, apesar de não ser nossa, nos gera ambientação suficiente para percebê-la, meio que vivenciá-la, enfim. Muitas vezes, se tem a sensação de ouvir "Faroeste Caboclo" ${ }^{3}$ mediante os relatos.

Desse modo, uma primeira observação importante a ser feita refere-se à relevância de se estabelecer a diferença entre a técnica de escrita de um Memorial e de outra narrativa autobiográfica. Uma narrativa autobiográfica tem a preocupação em refazer (contar, narrar) a trajetória de uma pessoa, em um determinado tempo, dos fatos relevantes que vêm à memória do autor. Esta narrativa pode conter diversas passagens da sua trajetória individual no tempo: nascimento, vivência familiar, escola, outros eventos e acontecimentos da vida pessoal mesclados com as dimensões coletivas do bairro, da cidade, do país ou do mundo enfim, de todos os acontecimentos que ocorrem à sua volta. Ou seja, a pessoa descreve esses acontecimentos da forma como eles ocorreram ou como ela os percebeu.

Já um relato reconstrói a trajetória pessoal, mas que tem uma dimensão reflexiva, pois implica que quem relata se coloca como sujeito que pergunta a si mesmo e deseja compreender-se como o sujeito de sua própria história. Assim, é um esforço de organização e análise do que vivemos. Esta diferença entre vivência e experiência é importante, dizendo assim:

${ }^{3}$ Faroeste Caboclo é uma canção do grupo brasileiro Legião Urbana, composta pelo compositor e lider da banda, Renato Russo. Composta em 1979, ela só foi lançada oficialmente em 1987, no álbum Que Pais É Este 1988/1987, pela gravadora EMI. 
"Numa autobiografia, a prática mais acabada desse arquivamento, não só escolhemos alguns acontecimentos, como os ordenamos numa narrativa; a escolha e a ordenação dos acontecimentos determinam o sentido que desejamos dar às nossas vidas." (ALTIÈRES,1998, p.11)

Isso reforça que a experiência, ao contrário da vivência, é refletida, pensada, e pode-se tornar algo consciente que construirá uma nova identidade, ou seja, um outro jeito de olharmos e pensarmos o mundo. Para ilustrar, seria possivel dizer que é como olhar a vida através de um "retrovisor", dando a chance de enxergar determinadas dimensões de nossa vida e refletir criticamente sobre o significado delas em nossa trajetória, tendo como vantagem o distanciamento temporal.

Para utilizar à memória e o imaginário na intenção que fique clara a concepção desses mesmos conceitos, que perpassam um ao outro e que se encontram imbricados na intersubjetividade; a relação que temos com nossa sociedade, a maneira de vermos e compreendermos o mundo - são elementos que procuramos forjar para que dê sentido às nossas ações, e mesmo assim distintamente um do outro.

Não há memória em que o imaginário não se faça presente, assim como não há imaginário sem que possamos encontrar nele a memória dos indivíduos, grupos ou sociedades. Sem memória, jamais poderíamos formar, forjar, construir nosso imaginário, do mesmo modo que o imaginário sobre algo ou alguém é essencial para formação de nossa memória. Sobre isso, Oliveira (2003) fala que nossa percepção não identifica o mundo exterior como ele é na realidade, e sim como as transformações, efetuadas pelos nossos órgãos dos sentidos, nos permitem reconhecê-lo. Assim é que transformamos fótons em imagens, vibrações em sons e ruídos e reações químicas em cheiros e gostos específicos e conduzimos essas impressões para nossa interpretação. Na verdade, o universo é incolor, inodoro, insípido e silencioso. Desse mesmo modo nossa memória é armazenada, levando-se em conta tanto a importância dada a certos aspectos pela pessoa que a armazenará, quanto a idiossincrasia, seu modo de ver e se relacionar com o mundo a sua volta.

Assim podemos notar que diversos assuntos sempre são repassados de maneiras diferentes e, em alguns casos, divergentes, dependendo do ponto de vista e da importância dada a certos detalhes pela pessoa que nos relata um determinado acontecimento - ponto de vista esse sempre dialogando com os segmentos sociais aos quais pertence. 
Na nossa ênfase, a influência do letramento na memória incide na capacidade de leitura de mundo, e de reflexão sobre as influências que corroboram as posturas. Quando se adquire confiança e articulação para escrever sobre isso, incorpora-se uma nova leitura sobre o acontecido e isso, e até mais que fazer suas memórias, é relê-las com a capacidade de entendê-las.

O estímulo da memória como instrumento através do qual o autor, enquanto apenado, articula a experiência com suas percepções interiores, aprimora sua capacidade de desenvolver seu letramento, pois tem como objetivo dar a oportunidade para refletir, através da escrita e da composição, sobre sua vivência de atuação junto aos movimentos sociais, lícitos ou não, dos quais tenha feito parte. Para isso, foram levadas em conta as condições e situações que envolvem sua trajetória, apresentando as questões que mobilizam sua atenção e evidenciando como elas se originam em sua história. Pelo seu caráter problematizador, reflexivo e sistematizador, o memorial se constitui em instrumento que serve de condutor para que o aluno, ao longo dos trabalhos, reúna elementos para a sua própria produção.

Dentro de uma função pedagógica-formativa e na medida em que o seu processo de elaboração e reelaboração ao longo das atividades - como um exercício contínuo e gradativo -, auxiliava o aluno no desenvolvimento e na articulação dos nexos entre a vivência de atuação social e as leituras partilhadas e discutidas, de modo a gerar uma interpretação crítica da sua experiência e da própria realidade que o cerca. Neste sentido, o a proposta de autoria funcionará como uma "ferramenta de suporte" que auxiliará o aluno em sua construção de letramento, dado que ele tem o objetivo de gerar uma reflexão sistemática, à luz dos conteúdos trabalhados paralelamente, como acerca de sua vivência local e os saberes aí constituídos.

Com a intenção de aprofundar a reflexão sobre esta sua história e prática, propomos que esta reflexão fosse feita, também, com sua capacidade de escrever sobre o conhecimento em si.

O objetivo que a experiência de escrita seja importante para que o aluno reflita sobre seu saber prático e o capacite a se tornar um formulador de novos caminhos e alternativas, reinventando novos modos de transformação social a partir de seu confronto com suas memórias, base desse processo - com a construção do conhecimento, que the proporciona a possibilidade de apontar o seu lugar de sujeito. 
A proposta é instaurar uma socialização "terapêutica", onde eles, ao se perceberem reais autores, adquiriram a confiança e um certo orgulho das suas vivências, independente do cunho social que elas vieram a ter para contribuir para sua situação de apenados. Com isso, pretendeu servir como uma ferramenta que auxiliaria o aluno na articulação do processo de ação-investigação-educação-ação no decorrer da construção de seu letramento; a descoberta do lugar em que esses alunos se considerem autores é o que se procura preencher ao dar-lhes voz. O passado é um território fechado para outras ações, não pode ser refeito, mas o futuro pode ser imaginado e pode começar a ser configurado na escrita, com toda a dificuldade encontrada por um preso para falar do futuro.

\section{CONSIDERAÇÕES FINAIS}

\section{A proposta}

Constituir autoria, formar autores de seu conhecimento, da organização de suas vivências, da valorização de suas impressões tornou-se o foco desse trabalho. Acompanhar alunos-autores e donos de tudo que puderam produzir, autores certificados de suas histórias e cientes de sua capacidade de falar sobre quem mais (hipoteticamente) conhecem bem que são eles próprios. Aprendendo a ler com prazer e criticidade, descobrindo o encanto da leitura como fonte de conhecimento, crescimento e reflexão; construindo esse processo com as próprias mãos, percebendo que ler envolve e potencializa outros inúmeros conhecimentos: lendo para entender o que é escrito, lendo para apreciar as palavras, lendo para refletir e questionar o meio, as posturas, o que são e o que somos. Lendo para crescer, para articular e para socializar. Lendo para o letramento nas diversas áreas do conhecimento.

As tecnologias do mundo moderno podem estar fazendo com que as pessoas deixem a leitura tradicional de lado. A leitura é algo crucial para a aprendizagem do ser humano, pois é através dela que podemos enriquecer nosso vocabulário, obter conhecimento, dinamizar o raciocínio e a interpretação. Geralmente a leitura, além dos benefícios do conhecimento, reflexão e articulação comprovados, torna a pessoa capaz

de autocorreção constante, nas questões ortográficas. Ou seja, ler "afugenta" a ocorrência de erros de grafia, de acentuação, de coesão e coerência. 
Muitas pessoas dizem não ter paciência para ler um livro, no entanto isso acontece por falta de hábito, pois, se a leitura fosse um hábito, as pessoas saberiam apreciar uma boa obra literária, por exemplo. Ler não requer paciência, requer interesse e aptidão para reconhecer o livro como ferramenta de prazer e aprendizado. $\mathrm{E}$ isso vem com o hábito, o cultivo da leitura.

Estimular a leitura é a primeira proposta para fazer da tríade letramento, memória e autoria um projeto que colabore para que os alunos se apropriem das suas próprias descobertas como agentes ativos de seu conhecimento. Lendo, eles se aproximam mais seguramente dos conteúdos programáticos do seu segmento escolar e isso ajuda muito na concretização, no êxito das atividades. Lendo, eles escrevem, progressivamente com mais segurança, segurança essa que fica explícita na letra mais firme, na ocupação espacial do caderno de forma mais ordenada, na prontidão de entender como se desenvolvem as atividades cotidianas e na reflexão sobre os textos trabalhados.

Dada a especificidade da realidade de um aluno de uma escola prisional, as restrições de atividades além da sala de aula, as visitas ou incursões por outros ambientes que contribuiriam para as propostas escolares foram substituídas pela capacidade de viajar na leitura. Lendo, sendo que possível diariamente, textos cuja leitura sempre enfocou a capacidade de associar a mensagem à reflexão da situação de apenado é a ferramenta mais simples e mais útil para alavancar esse trabalho.

Saber que eles mesmos socializam os textos entre os outros detentos que não frequentam a escola, conversar sobre o que essa partilha proporciona e usar isso como material de trabalho torna-se um método igualmente simples, mas também por isso, visivelmente eficaz para contribuir no que sempre será o objetivo maior deste projeto: aproximá-los da sua capacidade de construir seu conhecimento. Vemos isso acontecer através da leitura rotineira, quando os conhecimentos que caminham paralelos aos recursos utilizados preenchem seu papel real de principal meta.

As dúvidas ao escrever são diminuídas - quando não, sanadas - pelo hábito de ler; a confiança em produzir aumenta, na medida que eles percebem que não se trata de um concurso literário, que a escrita tem valor não por conta das palavras "difíceis" utilizadas ou pela ausência de erros ortográficos. Quando entendem que o valor está somente - na verdade, principalmente -- na consciência de ser capaz de escrever sem medo, sem pudor, escrever de si, sobre si, para si e para os outros, aprendem a orgulharem-se de suas produções. 
Isso é a base para a construção do conhecimento em todas as áreas do conhecimento que a escola abarca. Como afirmou Altières (1998), é um dever produzir lembranças; não fazê-lo é reconhecer um fracasso, é confessar a existência de segredos. Ressaltando sempre, contínua e exaustivamente que não caberia peso de julgamento referente às histórias contadas, a proposta de escrever sobre si, sendo autores de seus relatos e poder assim integrar-se à sua capacidade de expor suas experiências para a apreciação dos outros, dito assim:

"A obra, assim como a réplica do diálogo, visa a resposta do outro (dos outros), uma compreensão responsiva ativa, e para tanto adota todas as espécies de formas: busca exercer uma influência didática sobre o leitor, convencê-lo suscitar sua apreciação crítica, influir sobre êmulos e continuadores, etc."(BAKTHIN, 2000, p. 298)

Posto isso, pode-se dizer também que a função de autor tem relação com a dimensão enunciativa do sujeito do discurso, ou seja, tem a ver com a heterogeneidade interna a uma formação discursiva dominante, que ganha aí seu movimento e sua unidade sem perder, com isso, sua dominância. Em outras palavras, o que se escreve tem ligação com quem escreve, naturalmente, e isso alenca suas características, suas vivências e sua trajetória sendo transportada para o veículo de expressão que é a escrita, inicialmente, mas que não perde sua essência, seu veio, sua origem.

Também é dito que autoria está relacionada à questão ética, que vai da criação em si de uma obra ao direito inalienável do reconhecimento dos direitos autorais (ter seu nome associado à sua obra), ou seja, o direito a receber crédito por sua produção, que se aplica a qualquer forma de expressão, inclusive à Internet. Esses são conceitos consagrados em nosso ordenamento jurídico, seja pela Constituição Federal, seja pela lei ordinária, convenções, tratados internacionais e até mesmo pela Declaração dos Direitos do Homem. Possenti (2002) cita Foucault (1969) que apontou autores como "fundadores de discursividades", tais como Freud e Marx.

Essa noção interessa pouco aqui, porque, tipicamente, um aluno que escreve uma redação no vestibular, por exemplo, nem tem uma obra nem fundou uma discursividade. Ainda que tenha uma obra, não será julgado por ela por ocasião desse vestibular - ou seja, seu texto não será lido levando-se em conta sua obra. A proposta está além de discutir esta questão - textos de vestibulandos e outros textos escolares em termos de autoria, ou mesmo de descobrir uma brecha para introduzir no campo uma nova noção, além dessa de Foucault, de autoria. 
Seria possível dizer que esses autores "apartados" da definição foucaultiana se caracterizam não só por serem os autores de suas obras, mas também por terem produzido a possibilidade de realização de outros textos? Como disse Bakhtin (2000), quando há estilo, há gênero. Aqui, a proposta é defender a autoria como expressão que não impõe, não restringe, mas abre possibilidades para a experiência do conhecimento. Nem todos os valores são os mesmos para todos, ou as sensibilidades, idênticas. Ninguém deixa de ser autor, ou perde respaldo e/ou justificativa literária mediante uma nova forma de comunicação criada ou mídia explorada.

Por outro lado, formas de expressão distintas requerem uma abordagem e soluções igualmente diferenciadas. A diversidade (de meios, formas de expressão, culturas) pode ser um caminho para o caos e a desorganização; entretanto, sem caos, não há conhecimento. Sem frequente renúncia à razão, não há progresso. Não há uma só regra que seja válida em todas as circunstâncias, nem uma instância a que se possa apelar em todas as situações:

“(...) nossos enunciados (..) estão repletos das palavras dos outros, caracterizadas, em graus variáveis, pela alteridade ou assimilação, caracterizadas, também em graus variáveis, por um emprego consciente e recalcado. As palavras dos outros introduzem sua própria expressividade, seu tom valorativo, que assimilamos, reestruturamos, modificamos." (BAKTHIN, 2000, p.314)

Associada a esta última citação pode ser dito, por fim, que é impossível pensar nesta noção de autor sem considerar alguma noção de singularidade, que, por sua vez, não poderia escapar de uma aproximação com a capacidade de (re)compor a sua memória e expressá-la. E que esse conhecimento e capacidade só se faz realizável quando o indivíduo é munido das ferramentas da leitura e da escrita com as quais se constrói o processo de letramento. 


\section{REFERÊNCIAS}

ALBUQUERQUE Jr, Durval Muniz; VEIGA-NETO, Alfredo e FILHO, Alípio de Souza. (orgs) "Cartografia de Foucault" - - Belo Horizonte: Autêntica Editora, 2008. (Coleção Estudos Foucaultianos).

ARTIĖRES, Philippe. "Escrita de si/escrita da história: Arquivar a própria vida" Revista de Estudos Históricos, Rio de Janeiro. Editora FGV, vol. 11, n² 21, 1998.

BAKHTIN, M. Os gêneros do discurso. In: Estética da criação verbal. São Paulo: Martins Fontes, 2000

BAGNO, Marcos. Preconceito linguístico: o que é, como se faz. 21. ed. São Paulo: Loyola, 1999.

BIAR, Liana. Notas sobre Pragmática e pragmatismo nos estudos da linguagem. Mimeo: 2011.

BRAIT, Beth (org).Bakhtin, Dialogismo e construção do sentido. São Paulo, Editora da Unicamp, 1997.pág.281-288

CITELLI, Adilson Odair. "Educação e mudanças: novos modos de conhecer". In:_ _ _ (cood.) Outras linguagens na escola: publicidade, cinema e TV, rádio, jogos, informática. São Paulo: Cortez, 2001. (Coleção aprender a ensinar com textos; v.6)

FABRÍCIO, Branca Falabella e MOITA LOPES, Luiz Paulo. "A dinâmica dos (re)posicionamentos de sexualidades e práticas de letramento escolar: entre oscilações e desestabilizações sutis". In: MOITA LOPES, Luiz Paulo e BASTOS, Liliana Cabral. (Orgs.) Para além da identidade: fluxos, movimentos e trânsitos. Belo Horizonte: Editora UFMG, 2010.

FREIRE, Paulo. "A concepção 'bancária' da educação como instrumento da opressão. Seus pressupostos, sua crítica". In:_ _ _ Pedagogia do oprimido. 17a edição. Rio de Janeiro, Paz e Terra, 1987.

GIROUX, Henry A. "Professores como intelectuais transformadores". In:_ _ _ Os professores como intelectuais: rumo a uma pedagogia crítica da aprendizagem. Porto Alegre, RS: ArtMed, 1997.

HALBWACHS, Maurice. A Memória Coletiva. São Paulo: Ed. Centauro, 2004. 
KLEIMAN, Angela B. "Modelos de letramento e as práticas de alfabetização na escola". In:_- (Org.) Os significados do letramento: uma nova perspectiva sobre a prática social da escrita. Campinas, SP. Mercado de Letras, 1995.

LEMOS, Taísa Vliese de. Graciliano Ramos -- A infância pelas mãos do escritor -- um ensaio sobre a formação da subjetividade na psicologia sócio-histórica. Juiz de Fora: Editora UFJF/ Musa Editora, 2002.

OLIVEIRA, Jorge Martins de. Percepção e Realidade.

In:http://www.epub.org.br/cm/n04/opiniao/percepcao.htm Acesso em: 14 de setembro de 2012

POSSENTI, S. Indícios de autoria. Perspectiva, Florianópolis, 1-.20, n.01, p.105-124, jan./ un. 2002

ROJO, Roxane. "Letramento escolar, resultados e problemas: o insucesso escolar no Brasil do século XXI" In:_ _ _ Letramentos múltiplos, escola e inclusão social. São Paulo: Parábola Editoral, 2009.

SANTOS, Reinaldo Soares dos. O Encanto da Lagoa: O imaginário histórico-cultural como elemento propulsor para o turismo cultural na Lagoa Encantada. Dissertação (Mestrado em Cultura e Turismo) - Programa de Pós Graduação em Cultura e Turismo, UESC/UFBA, IlhéusBa, 2004.

SOARES, Magda. Letramento, um tema em três gêneros. Belo Horizonte: Autêntica, 2000.

STREET, Brian. Perspectivas interculturais sobre o letramento, 1984.

TERZI, Sylvia Bueno. "A orientação de letramento: a criança e sua comunidade". In (Org.) A construção da leitura: uma experiência com crianças em meios iletrados. Campinas, SP: Pontes, $2^{\mathrm{a}}$ edição, 2001.

YUNES, Eliana. "Pelo avesso: a leitura e o leitor. In: Quem é o leitor do $3^{\circ}$ milênio" $1^{\circ}$ seminário internacional . Novas Perspectivas em Educação. Salvador: Avante, Ed., 1996. 


\section{PLANO DE AÇÃO}

Planos de Ação:

- PLE - Projeto de Leitura na Escola

O Projeto de Leitura na Escola terá três culminâncias participação dos dois segmentos. Será um trabalho que perpassará mais objetivamente por todo o semestre. O tema é "Brasil 2018: na aba do meu chapéu você não pode ficar" e tem por objetivo munir o aluno da consciência e capacidade que ele tem de construir, dentro das diferentes áreas de conhecimento, sua própria produção textual remontando elementos de sua memória. As sugestões iniciais serão que os(as) professores munam seus alunos do conhecimento básico e que eles construam questões, atividades, dinâmicas, oficias e textos baseados nesse conteúdos. O professor(a) terá a liberdade de subdirecionar para o conteúdo e prática que achar mais adequados e relevantes para o perfil da(s) turma(s) e terá todo o apoio necessário para a execução do projeto; como também qualquer material necessário pode e deve ser pedido à direção para a possivel aquisição.

Datas: $1^{\text {a }}$ Culminância: $27 / 04 / 2018$

$2^{a}$ Culminância: 05/04/2018

$3^{\mathrm{a}}$ Culminância: $2^{\circ}$ semestre, a ser marcada.

- Avaliações

Todas ações didáticas e pedagógicas podem se converter em avaliações cognitivas e serem computadas como algumas das notas já que usamos de três (3) fontes de avaliação: prova, trabalho e teste.

Semana de Avaliação do $1^{\circ}$ semestre: $1^{\circ}$ bimestre será de 16/05 a 20/05 de 2018

$2^{\circ}$ bimestre será de $18 / 06$ a 22/06 de /2018

Semana de Avaliação do $2^{\circ}$ Semestre: $1^{\circ}$ bimestre de 17/09 a 21/09 de 2018

$2^{\circ}$ bimentre de 03/12 a 07/12 de 2018

* No calendário escolar desde ano, por conta alteração do período do recesso do meio do ano, é preciso atentar para o fato que o $1^{\circ}$ bimestre do $2^{\circ}$ semestre começa em julho.

- Literatura de telão

Títulos: Atividades Reguladas

Relembramos que as Atividades Reguladas são para respaldar a presença do aluno na ausência do(a) professor(a) e Ihe garantir tanto a assinatura da planilha de remição como a presença em Diário de Classe e ela só faz sentido se for aplicada no tempo real da aula do(a) docente que atende à(s) turma(s) por ocasião da sua ausência. 
O pedido de uma entrega antecipada de 5 (cinco) atividades reguladas é atender o propósito da atividade sem imprevistos

- Datas históricas e comemorativas

Promover atividades que envolvam as datas comemorativas dentro das áreas específicas de conhecimento contidas nos semestres letivos, trabalhando os temas e suas origens históricas/;regionais, destacando as peculiaridades e origem da data e seus desdobramentos históricos e sociais. 